UNIVERSIDADE DE SÃO PAULO

INSTITUTO DE GEOCIÊNCIAS

\title{
GEOMETRIA E CINEMÁTICA DE ALOJAMENTO DO MACIÇO GRANÍTICO ARROZAL, SUDOESTE DO ESTADO DO RIO DE JANEIRO
}

\author{
ALEXIS ROSA NUMMER
}

Orientador: Prof. Dr. Rômulo Machado

TESE DE DOUTORAMENTO

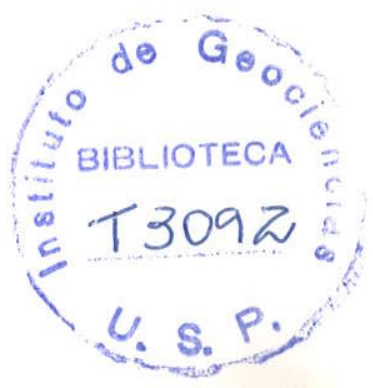

COMISSÃO JULGADORA

Nome

Assinatura

Presidente: Prof. Dr. Rômulo Machado

Examinadores: Prof. Dr. Elvo Fassbinder

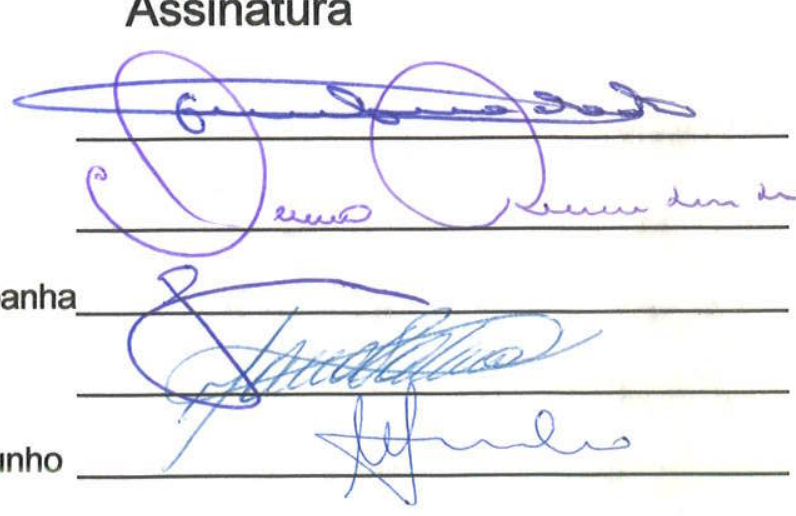

SÃO PAULO 


\title{
UNIVERSIDADE DE SÃO PAULO INSTITUTO DE GEOCIENCIAS
}

\section{GEOMETRIA E CINEMÁTICA DE ALOJAMENTO DO MACIÇO GRANÍTICO ARROZAL, SUDOESTE DO ESTADO DO RIO DE JANEIRO}

\author{
Alexis Rosa Nummer \\ Orientador: Prof. Dr. Rômulo Machado
}

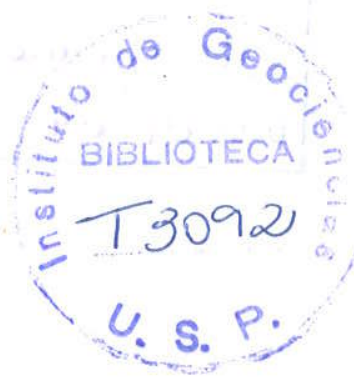

TESE DE DOUTORAMENTO

Programa de Pós-Graduação em Geoquímica e Geotectônica

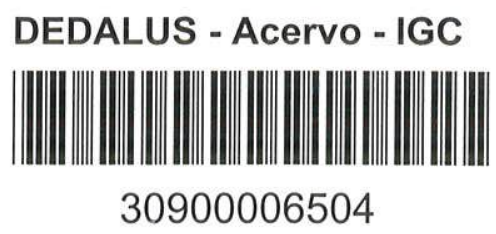

SÃO PAULO

2001 
"À minha esposa Patrícia e ao meu filho Bernardo" 


\section{Sumårio}

Agradecimentos...........................................................................

Lista de figuras..........................................................................

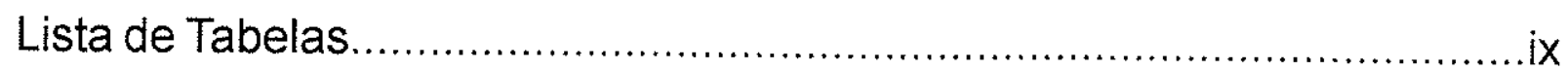

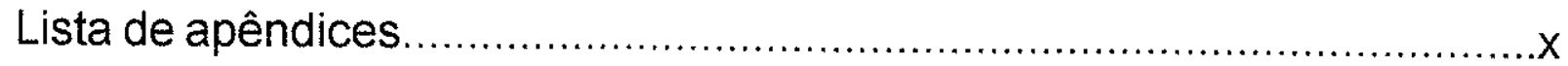

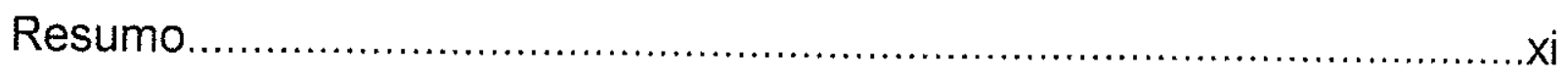

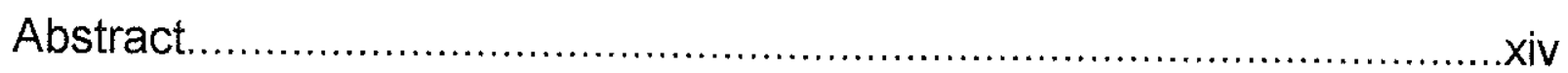

Capítulo 1 Introdução

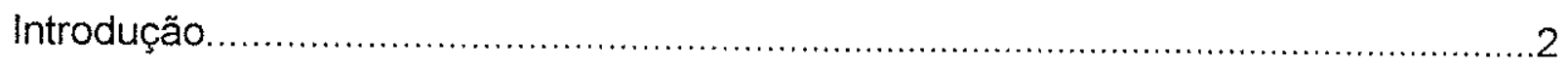

1.1. Objetivos e localização da área investigada.......................................................4

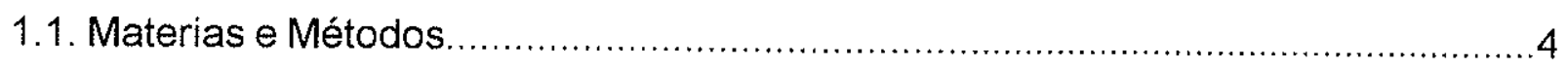

1.3. Contexto tectônico de geração de granitóides.......................................................3

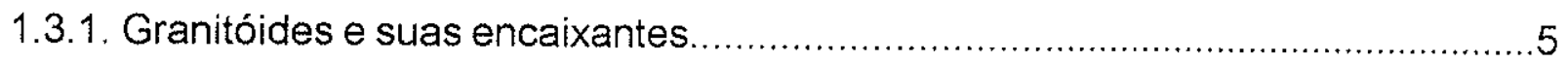

1.3.2. Regimes transpressionais e distensionais ...................................................6

1.3.3. Análise estrutural de plutons graníticos..........................................................8

1.3.4. Mecanismos de colocação de magmas graníticos...........................................10

1.3.5. Fatores de controle da colocação de magmas graníticos.................................11

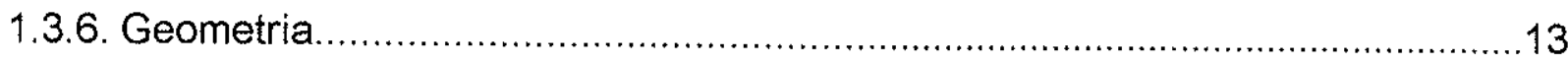

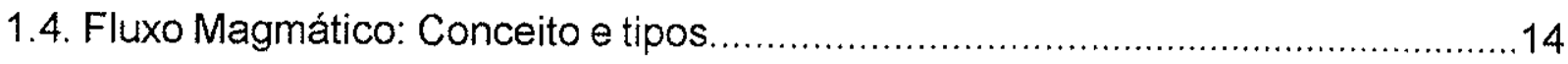

1.4.1. Evidências meso e microestruturais do fluxo magmático .................................15

1.4.2. Evidências micro e meso estruturais de fluxo no estado sólido ........................17

1.4.3. Fluxo Magmático X Fluxo Deformacional: Critérios de separação.....................18

1.4.4. Reologia no Estado Magmático....................................................................20

\section{Capítulo 2 Contexto Geotectônico Regional}

2.1. Evolução dos trabalhos geológicos...................................................................24

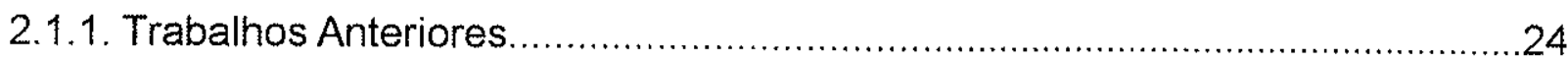

2.1.2. A estrutura divergente do Vale do Rio Paraíba do Sul...................................28

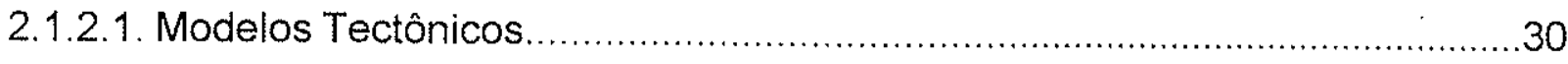

2.1.2.2. Modelos para o magmatismo Neoproterozóico .............................................31 
2.2. Compartimentação Tectônica do Rio de Janeiro.

2.3. Rochas Granitóides Neoproterozóicas do Estado do Rio de Janeiro. .35

2.3.1. Histórico. .35

2.3.2. Fases de deformações regionais. .36

2.3.3. Classificação Tectônica dos granitos no Domínio Paraíba do Sul. .37

2.4. Compartimentação Estrutural na região de Arrozal. .38

2.4.1. Domínio Quirino (DQ) 38

2.4.1.1. Ortognaisses. 39

2.4.1.2. Hornblenda Biotita Gnaisse. 40

2.4.1.3. Granada Moscovita Biotita Gnaisse. 40

2.4.2. Domínio Arrozal (DA) 41

2.4.3. Domínio Serra das Araras (DSA) .41

\section{Capitulo 3}

Suite Intrusiva Arrozal

Introdução. .43

3.1. Unidades litológicas. .45

3.1.1. Maciço Granítico Arrozal (MGA) .45

3.1.1.1. Fácies Porfirítica (central). .45

3.1.1.2. Fácies Foliada. .47

3.1.1.3. Fácies Leucogranítica. .49

3.1.1.4. Enclaves Máficos. 49

3.1.1.5. Diques e sills de rochas básicas. .49

3.1.2. Maciço Graníticos Getulândia (MGG)e Fortaleza (MGF). .50

3.2. Análise geométrica e cinemática .51 Introdução. .51

3.2.1. A Suite Intrusiva Arrozal (SIA) e as zonas de cisalhamento dúcteis. .52

3.2.2. A Suite Intrusiva Arrozal e as rochas encaixantes. 53

3.2.3. Análise Geométrica dos Dominios. 55

$\checkmark$ Dominio Quirino (DQ) .57

$\checkmark$ Dominio Arrozal (DA). .59

$\checkmark$ Dominio Serra das Araras (DSA) 61

3.2.4. Marcadores cinemáticos do Domínio Arrozal, 62 
3.2.5. Marcadores cinemáticos das rochas encaixantes (Domínios Quirino e Serra das Araras).

3.2.6. Padrão da Trajetória da Foliação Tectônica 62

3.2.7. Padrão da Trajetória da Lineação Tectônica 66

3.2.8. Relações entre deformação e metamorfismo. 66

Considerações Preliminares. 67

\section{Capitulo 4}

\section{Quimica Mineral e Geoquimica}

Química Mineral

4.1. Mineralogia. 69

Introdução. .69

4.1.1. Feldspatos .71

4.1.1.1. Feldspato alcalino. .71

4.1.1.2. Plagioclásio. .72

4.1.1.3. Micas .72

4.1.1.3. Biotita. .73

4.1.1.3.2. Mica Branca .80

4.1.1.4. Anfibólio. 82

4.1.5. IImenita .84

Discussão dos resultados. 84

Geoquímica

4.2 Caracterização geoquímica dos Granitóides da região de Arrozal. 88 Introdução. 88

4.2.1. Maciço Granitico Arrozal (MGA) ...................................................................90

4.2.1.1 Fácies porfirítico central e quartzo-monzonito leucocrático .............................90

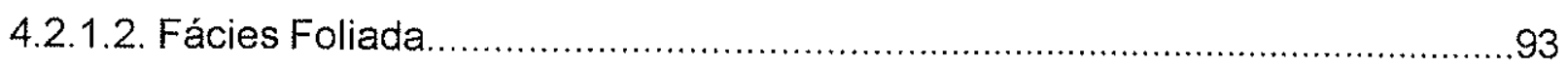

4.2.2. Maciço Granítico Getulândia (MGG) ...............................................................99

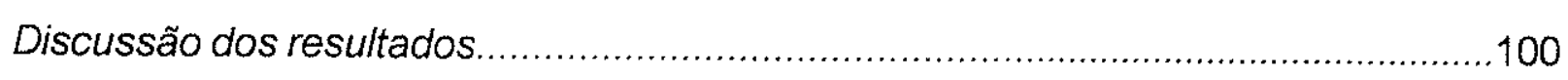

\section{Capítulo 5}

5.1. Considerações Preliminares 113 Introdução 
5.2. Análise dos modelos tectônicos existentes sobre a cinemática de alojamento de granitos no Rio de Janeiro

5.1.2. Característica e distribuição dos granitóides.

5.1.3. Suíte Intrusiva Arrozal. .116

5.2. Análise e interpretação de imagem LANDSAT. 116

5.3 Gravimetria do Maciço Granático Arrozal. 117

Introdução.

5.3.1. A importância e aplicação do método. 118

5.3.2. Redução dos dados gravimétricos 120

5.4. Gravimetria da região de Arrozal. 122

5.5. Modelo de Alojamento da Suíte Intrusiva Arrozal. 126

Considerações finais. 130

\section{Capítulo 6}

\section{Conclusőes}

Conclusões 131

Referências Bibliográficas

Apêndices

7.1. Trabalho de Campo 165

7.1.1. Análise Geométrica. 165

7.1.2. Análise Cinemática 166

7.1.4. Gravimetria. 166

7.2 Fase de Laboratório 167

7.2.1. Análises Petrográficas e microestruturais 167

7.2.2. Análises Litogeoquímicas. 168

7.3. Fase de Gabinete. 169

7.3.2. Sensoriamento remoto 169 


\section{Agradecimentos}

Este trabalho contou com a colaboração de vária pessoas e instituições. Inicialmente, agradeço ao meu orientador prof. Dr. Rômulo Machado pela colaboração, discussões e sucessivas revisões do texto final da tese bem como pelo incentivo, dedicação e companheirismo, que possibilitaram ao autor realizar os primeiros passos no campo de pesquisas em granitos (corpo desta tese) com a inserção de novas abordagens e métodos. Comecei aqui.

Este trabalho contou com o apoio financeiro da Fundação de Amparo a Pesquisa do Estado de São Paulo (FAPESP), processo 1998/0912-8, para a realização dos trabalhos de campo e laboratório, e do Programa de Incentivo à Capacitação Docente e Técnica - Administrativa (PICDt) da Universidade Federal Rural do Rio de Janeiro, sob forma de bolsa de doutorado. Contou ainda, com o apoio do Programa de Apoio ao Ensino (PAE) do Programa de Pós-Graduação do IG-USP (Bolsa de Estágio).

Os trabalhos de campo foram realizados ao longo dos últimos 8 anos e contaram com a colaboração dos alunos de graduação em Geologia da UFRuraIRJ dos anos 1993, 1994, 1995 e 1998, e especial apoio do aluno Mateus Delatim Simonato (USP).

0 apoio logístico (alojamento) foi gentilmente cedido pela Arquidiocese de Volta Redonda com a colaboração das "meninas": Dona Maria, Irene e Teresinha. discussões.

A análise cinemática teve a colaboração do geólogo e doutorando Nolan Dehler (USP), com sugestões e

A realização do trabalho de campo de gravimetria contou com a prestimosa colaboração inicial do prof. Dr. Hans Dirk Ebert (UNESP - Rio Claro) e do geólogo Dr. Ricardo Trindade (IAG-USP); com a importante e prestimosa colaboração do pós-graduando geólogo Sergio Henrique Sousa Almeida (UNESP) no tratamento e modelagem de dados gravimétricos e contou com o apoio do geofisico Steve Balch (INCO-Sudbury, Canadá).

As análises petrográficas foram realizadas no laboratório de microscopia do Departamento Geologia Geral (USP), e alguns estudos petrográficos foram executados com apoio do Departamento de Mineralogia e Petrologia(USP), e setor de Petrologia e Mapeamento Geológico da UFRuralRJ.

As análises litogeoquimicas e de química mineral contaram com a valiosa colaboração dos professores Dr. Luis Antônio Rosa Seixas, MSc. Heloisa Dehler e Dr. Sérgio de Castro Valente, que através de sugestões e comentários muito contribuiram para o bom aproveitamento dos dados obtidos.

A fase de gabinete contou com o importante apoio da Divisão de Geoprocessamento da Companhia de Pesquisas e Recursos Minerais (DIGEOP.CPRM), bem como dos Laboratórios de Geoprocessamento da UFRuraIRJ e da USP.

$O$ trabalho de geoprocessamento e confecção dos mapas geológico e estrutural tiveram a colaboração da geóloga e esposa Patricia Duringer Jacques (CPRM-RJ), e geólogos e engenheiro de minas do DIGEOPCPRM-RJ, em especial Ricardo Moacyr de Vasconcellos, Paulo C. A. Branco, Jorge Pimentel, e técnicos Francisco, Pablo e Mauricio, na utilização dos programas ENVI, PCl e MaxCad.

Aos colegas, funcionários e alunos do DEGEOC - UFRRJ; Decanato de Pesquisa e Pós-Graduação da UFRural RJ e do Programa de Pós-Graduação IG-USP.

Os agradecimentos fraternos são dedicados à minha familia: Ivone (mãe), Tarzan (pai), Leila, Alessandro, Lilian e Ingrid (in memoniam)(irmãos), aos meus sobrinhos Lucas, Patricia, Thiago, Ana Paula, Thaiana e Shayara (RS); Maria, Julia, Thomas (RJ), cunhados(as) Roberto, Paulinho, Eros e Adriana, ao sogrão Alfredo e sogrona Carminha, e aos queridos amigos Tariana, Luci, Tiago (SP).

E para finalizar, minha gratidão aos amigos Andrezinho, Moniquinha, Olga, Caio, Adriana, Zé Dias (UFRRJ), Luciana Rodella (USP); Regina, Clarice, Marcelo (RJ) e em especial ao "Rogérinho" - Rô (CA), que incentivaram com apoio e companheirismo a execução desta tese. 


\section{Lista de Figuras}

Fig. 1.1 -Mapa geológico simplificado da região de Arrozal (A) e contexto geotectônico dos granitóides do sudoeste do Estado (B)(Machado 1997).

Fig. 2.1 - Compartimentação tectônica dos granitos Neoproterozóicos no Estado do Rio de Janeiro, extraído de Machado \& Demange (1994).

Fig. 3.1 - Mapa geológico simplificado da região de arrozal, sudoeste do estado do Rio de Janeiro, com a divisão em domínios litoestruturais, esc:1:350.000.

Fig. 3.2 - Mapa estrutural simplificado da região de Arrozal, sudoeste do estado do Rio de Janeiro, com a divisão em domínios estruturais, esc:1:350.000.

Fig. 3.3 - Esterogramas para foliações e lineações tectônicas do Domínio Estrutural Homogêneo Noroeste, plotados em diagramas Schimidt, hemisfério inferior. 58

Fig. 3.4 - Esterogramas para foliações e lineações tectônicas do Domínio Estrutural Homogêneo NW, Central e SE, plotados em diagramas Schimidt, hemisfério inferior.

Fig. 3.5 - Estruturas de fluxo magmático na Zona de Cisalhamento de Arrozal.........63

Fig. 3.6 - Estruturas em escala mesoscópica ..........................................................64

Fig. 3.4 - Zonas de cisalhamento dúcteis

Fig.4.1. Localização das amostras utilizadas nos estudos de Química Mineral da Suíte Intrusiva Arrozal.

Fig.4.2. Diagrama triangular de classificação Or - Ab - An de Feldspato alcalino......71

Fig.4.3. Diagramas das biotitas e classificação segundo Nachit (1986). .74

Fig.4.4. Diagramas de classificação e substituições entre $R^{2}$ versus elementos $R^{3}$ em biotitas da Suíte Intrusiva Arrozal.

Fig.4.5a. Gráfico de classificação Al2O3 vs. FeO, para biotitas proposto por Abdel Rahman (1994)

Fig.4.5b. Diagrama de classificação de biotitas (Chevremont et al 1988) ...................78

Fig.4.6. Gráficos de substituições $R_{3} v s$. componentes $R_{2}$ para biotitas. .79

Fig.4.7. Diagramas de substituições do tipo clitonita e talco para biotitas e classificação de micas brancas.

Fig. 4.8. Diagramas de classificação e substituições dos anfibólios e piroxênio. 83

Fig.4.9. Diagramas de substituições do tipo edenita e riebeckita, em anfibólios .85 
Fig.4.10. Localização das amostras dos estudos de litogeoquímicas da SIA.

Fig.4.11.Diagramas geoquímicos para a fácies porfirítica e quartzo monzonito associado e de Harker.

Fig.4.12. Variação composicional das rochas da fácies foliada, comparadas com a fácies porfirítica

Fig.4.13. Diagramas de Harker da fácies foliada em comparação com a fácies porfirítica

Fig. 4.15. Diagramas de classificação de Streckeisen (1976) e discriminantes de ambientes tectônicos para as que compõem a Suíte Intrusiva Arrozal. 98

Fig. 5.1. Mapa Bouguer da região de Arrozal obtido através do método de triangulação sobre a base geológica. 123

Fig. 5.2. Perfís de anomalias gravimétricas sucessivos obtido no programa DATAMINE. 124

Fig. 5.3. Perfil Raso (3D) obtido através do programa DATAMINE 125

Fig. 5.4. Modelo proposto para a cinemática de alojamento da SIA 129 


\section{Lista de Tabelas}

Tabela 4.1. Dados químicos das amostras contendo feldspatos alcalinos 102

Tabela 4.2. Dados químicos dos plagioclásios. 103

Tabela 4.3. Análises químicas de micas (biotitas)(primeira parte). 104

Tabela 4.4. Análises químicas de micas (biotitas)(Segunda parte) 105

Tabela 4.5. Análises químicas de micas (biotitas)(terceira parte) 106

Tabela 4.6. Análises químicas de micas (biotitas)(Quarta parte). 107

Tabela 4.7. Análises químicas de micas (mica branca). 108

Tabela 4.8. Análises litogeoquímicas das amostras da Suíte Intrusiva Arrozal. 109 


\section{Lista de APENDICES}

APÊNDICE 1 - Descrição dos Materiais e métodos, dados de campo e estruturais e nomenclatura adotada.

APENNDICE 2 - Geologia Estrutural e interpretação de Imagem de Satélite LANDSAT 5 (TM 3) da Suíte Intrusiva Arrozal (escala 1:100:000).

APÊNDICE 3 - Imagem LANDSAT 5TM (banda 3) com contatos geológicos da região de Arrozal (escala 1:100:000) 


\section{RESUMO}

A área estudada na compreende uma região limitada pelos municípios de Rio Claro (SW) e Vassouras (NE), enquadrada entre os meridianos $41^{\circ} 20^{\prime} 30^{\prime \prime} \mathrm{S}$ e paralelos $24^{\circ} 30^{\prime} 20^{\prime \prime} W$, no Vale do Rio Paraíba do Sul, constituída por litologias relacionadas ao Domínio Paraíba do Sul com estruturas tectônicas do tipo Zonas de Cisalhamento Dúctil (ZCD) em regime transpressional, e granitóides tardi a pós-tectônicos associados.

- Maciço Granítico Arrozal (MGA) faz parte do magmatismo granítico Neoproterozóico da parte central do cinturão do Paraíba do Sul, com idade no intervalo de 600 a $490 \mathrm{Ma}$, que tem sido dividido em quatro grupos principais de granitos: (i) pré colisionais; (ii) colisionais; (iii) tardi colisionais e, (iv) pós colisionais. O MGA corresponde aos granitos classificados como tardi colisionais (sin- a tardi-F3 das classificações tectônicas disponiveis).

A associação entre os maciços graníticos Arrozal, Getulândia e Fortaleza apresentam a mesma identidade estrutural e composicional, que são integradas na Suíte Intrusiva Arrozal.

O MGA, com expressão areal menor, ao redor de $101,3 \mathrm{Km}^{2}$, possui eixo maior orientado na direção $N 70^{\circ} \mathrm{E}$, e encontra-se alojado entre as zonas de cisalhamento dúcteis de alto ângulo de Além Paraíba (a noroeste) e Mendes (a sudeste), sendo secionado à norte pela zona de cisalhamento de alto ângulo de Arrozal.

Foram individualizadas, com base em critérios composicionais e deformacionais, três faciologias principais: porfirítica, situada na parte central do maciço, foliada, disposta marginalmente ao corpo, e leucogranítica, na sua extremidade noroeste. A composição dominante é granodiorítica e monzogranítica subordinada. Localmente ocorrem bolsões hololeucocráticos de composição quartzo monzonítica.

Os Maciços Getulândia (MGG) e Fortaleza(MGF), de maior expressão areal na região, apresentam formas mais alongadas e eixos maiores e coincidentes com o MGA e apresentam composições monzo a sieno-graniticas predominantes.

A área estudada foi dividida em três domínios estruturais homogêneos: Domínio NW (Domínio Quirino), Domínio Central (Domínio Arrozal) e Domínio SE (Domínio Serra das Araras). O primeiro domínio possui orientação geral $N 75^{\circ} E$, com mergulhos variáveis para NW e SE; o segundo, com orientação dominante na direção $N 45^{\circ} E$, tendo mergulhos mais 
suaves para a foliação magmática e mais acentuados para foliação tectônica; o terceiro, com orientação estrutural semelhante ao primeiro $\left(\mathrm{N} 69^{\circ} \mathrm{E}\right)$, porém com mergulhos mais elevados para NW.

Os dados geoquímicos possibilitaram caracterizar o MGA como magmatismo cálcioalcalino alto $\mathrm{K}$ a shoshonítico. meta aluminoso ( $\mathrm{A} / \mathrm{CNK}, \sim 0,9$, fácies leucogranítica) a marginalmente peraluminoso ( $\mathrm{A} / \mathrm{CNK}$, entre 1,1 a 1,2 na fácies porfirítica e foliada), apresentando durante a diferenciação magmática o empobrecimento em $\mathrm{Ca}, \mathrm{Sr}$, $\mathrm{Ba}, \mathrm{Zr}$ e na soma de $\mathrm{FMMT}\left(\mathrm{Fe}_{2} \mathrm{O}_{3}+\mathrm{MgO}+\mathrm{MnO}+\mathrm{TiO}_{2}\right.$ ), refletido na cristalização dos feldspatos, zircão, apatita, biotita, ilmenita e magnetita, e enriquecimento $\mathrm{K}_{2} \mathrm{O}, \mathrm{Rb}$ representado principalmente pela cristalização de feldspato potássico.

O comportamento dos elementos maiores ( $\mathrm{Ca}, \mathrm{K}_{2} \mathrm{O}, \mathrm{K}_{2} \mathrm{O} / \mathrm{Na}_{2} \mathrm{O}$ e a soma dos FMMT) e traços ( $\mathrm{Ba}, \mathrm{Sr}, \mathrm{Zr}$ e $\mathrm{Rb})$ é semelhante durante a diferenciação entre as fácies porfirítica e foliada do MGA, mostrando que o processo deformacional (no estado sub sólido) não foi suficientemente intenso para promover alterações significativas no comportamento químico desses elementos. A comparação com as amostras do MGG evidencia o caráter mais evoluído deste último, com os teores mais elevados em SiO2 (70,8 a 75,3\%, contra 63,2 a $69,3 \%), \mathrm{K} 2 \mathrm{O}(4,2$ a $4,6 \%$, contra 3,1 a $4,6 \%)$, (Na2O / K2O > 1,8\%, contra 0,9 e 1,7\%) e Rb (252 e 327 ppm, contra 136 a 220 ppm).

A química mineral permitiu caracterizar nesses maciços a existência de dois grupos principais de plagioclásio: um de composição albita e oligoclásio - MGG, fácies leucogranítica, MGA e Unidade Quirino, e outro de composição andesina - fácies porfirítica e foliada do MGA, enclave quartzo diorítico do MGA e dique de diorito que corta o MGA). $O$ feldspato alcalino destes maciços é essencialmente ortoclásio, com valores de An sempre inferiores a $20 \%$. Foram distinguidos dois grupos de biotitas: um grupo de biotitas encontrado nos MGA e MGG, caracterizado por uma biotita muito férrica (annita), e outro grupo encontrado na fácies foliada do MGA, classificada como biotita magnesiana (siderofilita).

O modelamento gravimétrica apresenta um boa correlação com dados estruturais obtidos e permitiu deduzir a geometria em $3 D$ do corpo, indicando uma anomalia gravimétrica negativa com disposição coincidente com a Zona de Cisalhamento de Mendes (ZCM). O perfil gravimétrico obtido sugere uma profundidade ao redor de $7,5 \mathrm{Km}$ para o 
limite inferior do corpo. Estes dados, em conjunto com os dados estruturais, permitem inferir, em perfil, uma geometria tipo estrutura em flor (hemi-flor) positiva associada às zonas de cisalhamento Além Paraíba e Mendes, as quais podem coalescer em profundidade.

O ambiente tectônico de alojamento do MGA é vinculado à zonas de cisalhamento dúcteis direcionais desenvolvidas em regime transpressivo, ao longo de um sítio extensional (ZCA) num modelo tectônico do tipo releasing bend. Este sítio associa-se regionalmente à inflexão da Zona de Cisalhamento Além Paraíba, que muda de direção geral $\mathrm{N} 45^{\circ} \mathrm{E}$ para direção $\mathrm{N} 70^{\circ} \mathrm{E}$.

O modelo de alojamento de magma granítico mais adequado ao MGA é do tipo diques múltiplos (estágio inicial de ascenção) associado a diápiro (estágio final e de acumulação). 


\section{ABSTRACT}

The study area is limited by coordinates $41^{\circ} 20^{\prime} 30^{\prime \prime} \mathrm{S}$ and $24^{\circ} 30^{\prime} 20^{\prime \prime} \mathrm{W}$ and includes the Rio Claro city to the southwest and Vassouras to the northeast in the Paraiba do Sul river valley. It comprises transpressional, ductile shear zones with lithologies associated with the so-called Paraiba do Sul Domain as well as late- and post-tectonic granitoids.

The Arrozal Granitic Massif (AGM) is related to the Neoproterozoic (c.a. 600-490Ma) granitic magmatism within the central part of the Paraiba do Sul Thrust Belt. This granitic magmatism includes four main granite types as such: (i) pre-collisional, (ii) collisional, (iii) late-collisional and (iv) post-collisional. Late-collisional (or sin- late- $\mathrm{D}_{3}$ ) granites occur in the AGM.

An association among the Arrozal, Getulândia and Fortaleza granitic massifs is made on the basis of structural and compositional similarities, all being included in the Arrozal Intrusive Suite.

The relatively smaller AGM covers an area of $101,3 \mathrm{Km}^{2}$. It has a N70'E-oriented major axis and is emplaced between the Além Paraiba (to the NW) and Mendes (to the SE) high-angle, ductile shear zones, being cut to the north by the Arrozal high-angle shear zone.

Three main granitic facies can be distinghished on the basis of compositional and structural criteria: porphyritic, in the central part of the massif; foliated, at the pluton edges and leucogranitic, to the NW. It is mainly granodioritic and less often monzogranitic in composition with local hololeucocratic quartzmonzonitic pods.

The Getulândia (GGM) and Fortaleza (FGM) granitic massifs are bigger than the AGM. They lie subparallel to but are more enlongated than the AGM, being monzo- and sienogranitic in composition.

The study area was divided in three main homogeneous structural domains: the NW Domain (Quirino Domain), the Central Domain (Arrozal Domain) and the SE Domain (Serra das Araras Domain). The Quirino Domain displays a general $N 75^{\circ} \mathrm{E}$ orientation with varible dips to the NW and SE. The Arrozal Domain displays a general N45 E orientation with less steep magmatic foliation and more steep tectonic foliation. The Serra das Araras Domain is 
subparallel to the Quirino Domain $\left(\mathrm{N} 69^{\circ} \mathrm{E}\right)$ but with steeper dips to the NW. The mineral lineations are usually to the NE and less often to the SW.

The geochemical data showed that the AGM represents a high-K to shoshonitic, calcalkaline, metaluminous suite (A/CNK $\sim 1.1-1.2$ in the porphyritic and foliated facies). It shows $\mathrm{Ca}, \mathrm{Sr}, \mathrm{Ba}, \mathrm{Zr}$ and $\mathrm{FMMT}\left(\mathrm{Fe}_{2} \mathrm{O}_{3}+\mathrm{MgO}+\mathrm{MnO}+\mathrm{TiO}_{2}\right)$ depletion possibly as a consequence of feldspar, zircon, apatite, biotite, ilmenite and magnetite crystallisation. The feldspar crystallisation was also responsible for the $\mathrm{K}_{2} \mathrm{O}$ and $\mathrm{Rb}$ enrichment in the suite.

Major ( $\mathrm{Ca}, \mathrm{K}_{2} \mathrm{O}, \mathrm{K}_{2} \mathrm{O} / \mathrm{Na}_{2} \mathrm{O}$ and FMMT) and trace ( $\mathrm{Ba}, \mathrm{Sr}, \mathrm{Zr}$ and $\mathrm{Rb}$ ) element variations are similar for the porphyritic and foliated facies showing that the subsolidus deformation had no control on the differentiation process. The geochemical data also showed that the GGM represents a more differentiated suite as shown by its higher $\mathrm{SiO}_{2}$ (70.8-75.3 wt. \%), $\mathrm{K}_{2} \mathrm{O}\left(4.2-4.6\right.$ wt. \%), $\mathrm{Na}_{2} \mathrm{O} / \mathrm{K}_{2} \mathrm{O}$ (1.8) and $\mathrm{Rb}(252-327$ ppm) contents when compared with the AGM and the FGM (SiO2=63.2-69.3 wt.\%), $\mathrm{K}_{2} \mathrm{O}(3.1-4.6 \mathrm{wt} \%$ ), $\mathrm{Na}_{2} \mathrm{O} / \mathrm{K}_{2} \mathrm{O}(9-1.7)$ and $\left.\mathrm{Rb}=136-220 \mathrm{ppm}\right)$.

Mineral chemistry data pointed to two main plagioclase groups, as such: albiteoligoclase (GGM leucogranite facies; AGM and Quirino Domain) and andesine (AGM porphyritic and foliated facies; AGM quartzdioritic enclave and diorite dyke that cuts the AGM). The potassium feldspar of those massifs is essentially orthoclase, with $A n<20 \%$. Two biotite groups can be distinguished; a annite group in the AGM and GGM and a siderophilite group found in the AGM foliated facies.

The $3 D$ geometry of the AGM suite was obtained by gravimetric modelling which correlated well with the field structural data. The modelling points to a negative gravimetric anomaly parallel to the Além Paraíba Shear Zone (APSZ). The gravimetric profile indicates a value of maximum depth of $\sim 7.5 \mathrm{Km}$. The geophysical data point to a positive hemi-flower strcucture that can be associated with the Além Paraíba Shear Zone and that may coalesce at greater depth.

The tectonic setting prevalling during the AGM intrusion can be related to transpressive ductile shear zones developed in an releasing bend type of extensional field. This field can be associated in a regional scale with the APSZ inflection from $N 45^{\circ} \mathrm{E}$ to $\mathrm{N} 70^{\circ} \mathrm{E}$.

The best emplacement model for the AGM is that of multiple dykes (at the initial emplacement stage) associated with diapirism (towards the final stages). 


\section{CAPITULO 1}

\section{Introdução}

Introduçăo

1.1. Objetivos e localizaçăo da área investigada

1.2. Materiais e Métodos.

1.3. Contexto tectônico de geraçăo de granitóides............................................

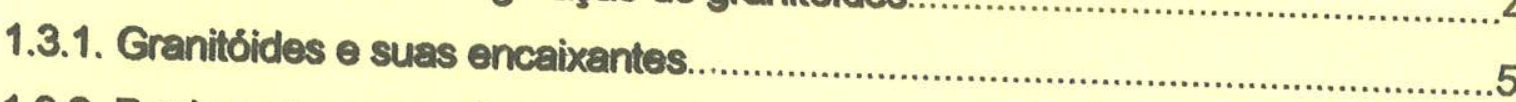

1.3.2. Regimes transpressionais e distensionais..................................................

1.3.3. Análise estrutural de plutons graníticos.......................................................

1.3.4. Mecanismos de colocaçåo de magmas graníticos.......................................10

1.3.5. Fatores que controlam a colocaçăo de magmas graníticos..........................11

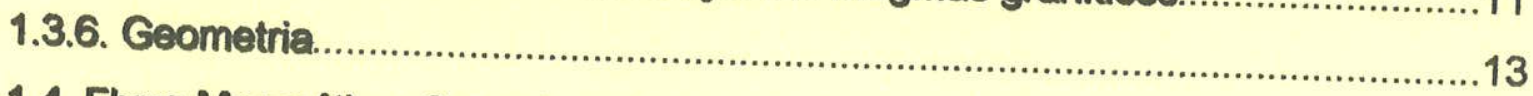

1.4. Fluxo Magmático: Conceito $\Theta$ tipos...............................................................14

1.4.1. Evidéncias meso $\Theta$ microestruturais do fluxo magmático................................15

1.4.2. Evidéncias micro e meso estruturais de fluxo no estado sólido.....................17

1.4.3. Fluxo Magmático X Fluxo Deformacional: Critérios de separaçăo..................18

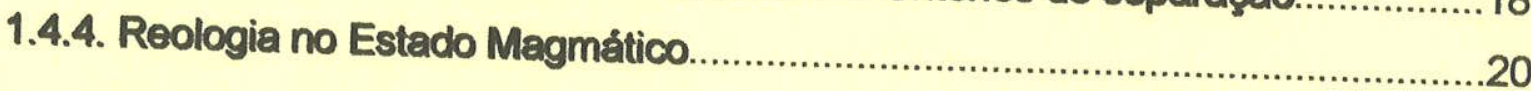




\section{Introdução}

No Cinturão Paraíba do Sul (Ebert 1968), Estado do Rio de Janeiro, não são disponiveis até o momento estudos sobre as rochas granitóides envolvendo metodologias integradas como cartografia geológica, análise estrutural (geométrica e cinemática), informações geofísicas (gravimétricas), dados geoquímicos e isotópicos, que possibilitem uma avaliação mais realística em termos de origem, ascensão e dinâmica de colocação do magmatismo Neoproterozóico na região.

Deste modo, o presente estudo passa a ser relevante, pois representa uma primeira abordagem integrada envolvendo tais metodologias com vistas ao entendimento da colocação de granitos sintectônicos relacionados à zonas de cisalhamento dúcteis de alto ângulo associados ao Lineamento de Além-Paraíba (LAP). Para isso, são apresentados resultados de mapeamento geológico-estrutural de detalhe realizado sobre - Maciço Granítico de Arrozal e suas encaixantes, incluindo análise geométrica dos elementos planares e lineares, estudos petrográficos e microtectônicos, dados litogeoquímicos, isotópicos e gravimétricos, juntamente com uma revisão dos trabalhos disponiveis sobre a temática aqui envolvida.

Uma das dificuldades encontradas na região para o estudo das rochas granitóides é a precariedade da base cartográfica existente, sobretudo no vale do Rio Paraíba do Sul, onde muitos dos granitóides deformados associados à zonas cisalhamento de alto ângulo regionais foram cartografados, nos mapeamentos coordenados pelo Departamento de Recursos Minerais do Estado do Rio de Janeiro (DRM), como gnaisses regionais $e$, muitas vezes, englobados de forma inadequada como unidades de migmatitos.

Uma decorrência disso, é que os granitóides Neoproterozóicos da região são, na realidade, mais volumosas do que têm sido assinaladas nos mapas de integração até então apresentados. Isto pode ser exemplificado na área estudada pelos maciços graníticos Getulândia e Arrozal (parte), os quais não foram individualizados adequadamente na cartografia geológica na escala 1:50.000 realizada pela CPRM.

A região estudada foi dividida em três domínios litoestruturais: Domínio Quirino (DQ), situado na porção NW da área (Fig.1.1a); Domínio Arrozal (DA), situado na porção central, onde afloram as rochas granitóides e, Domínio Serra das Araras (DSA), situado na porção SE da mesma, correspondendo ao domínio mais heterogêneo de todos, sendo caracterizado por uma associação de rochas metassedimentares com granitóides tipo-l e tipo-S associados. 


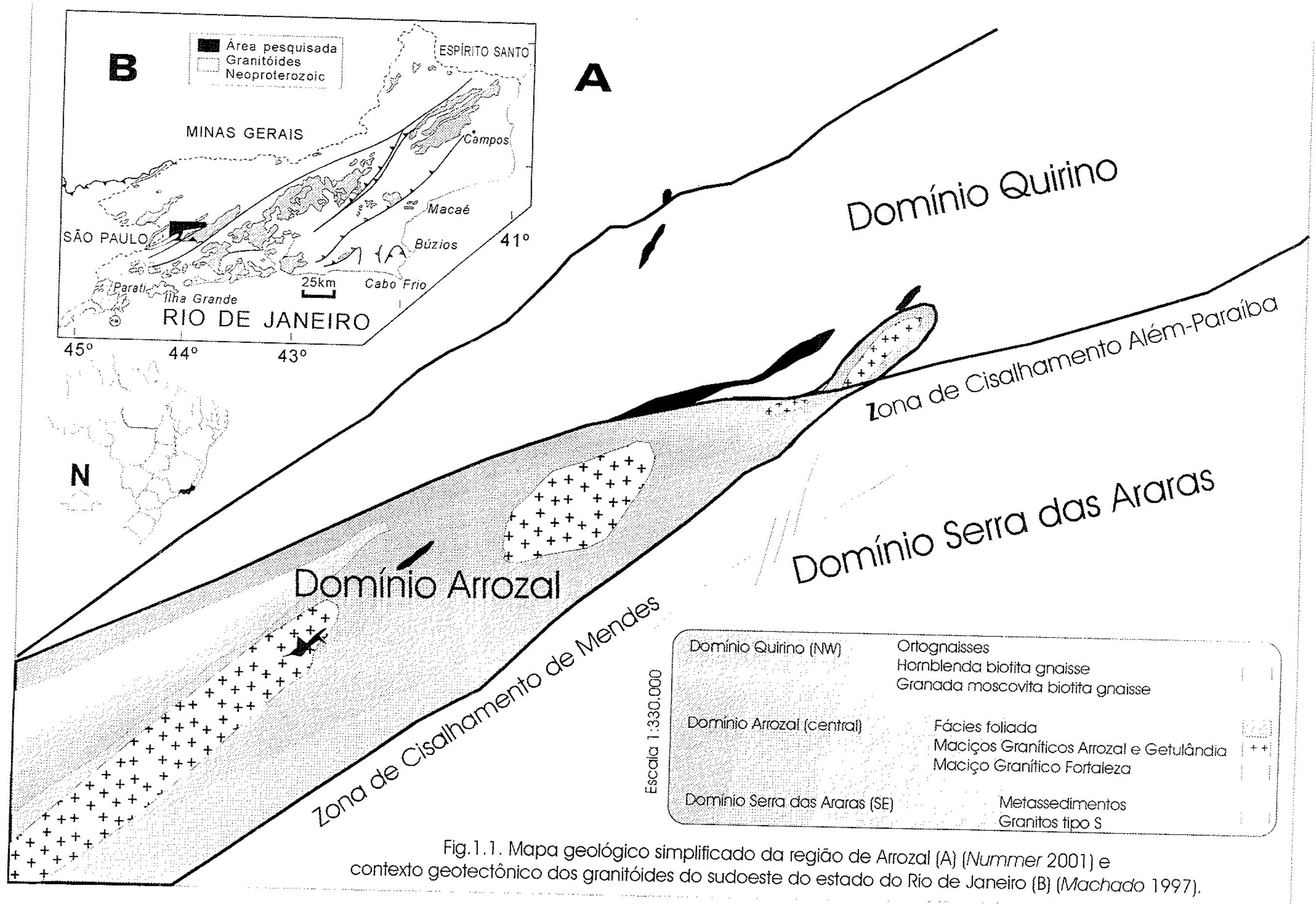




\subsection{Objetivos e Localização da área investigada}

O objetivo principal deste trabalho é definir, com base no mapeamento geológicoestrutural de detalhe e semi-detalhe, em dados petrográficos, estruturais, geoquímicos e geofísicos o modelo de colocação do Maciço Granitico Arrozal no contexto das zonas de cisalhamento de alto ângulo do vale do Rio Paraíba do Sul.

O Maciço Granítico Arrozal (MGA) está localizado na porção sudoeste do Estado do Rio de Janeiro e acha-se inserido entre os meridianos $41^{\circ} 15^{\prime} 00^{\prime \prime}$ e $43^{\circ} 45^{\prime} 40^{\prime \prime}$ de latitude sul e os paralelos $22^{\circ} 30^{\prime} 00^{\prime \prime}$ e $-22^{\circ} 45^{\prime} 00^{\prime \prime}$ de longitude oeste (Fig.1.1b).

A região é cortada na parte norte pela rodovia Presidente Dutra, entre o trecho Barra Mansa e Piraí, e a sul, pela rodovia RJ-139 que liga as localidades de Passa Três a Getulândia. A parte oeste da área é balizada pela rodovia $\mathrm{Br} 462$, que liga as cidades de Barra Mansa a Angra dos Reis, passando por Getulândia e Rio Claro, próximo aos fimites dos estados do Rio de Janeiro e São Paulo.

A cidade de Arrozal situa-se na borda norte do maciço e pode ser alcançada pela rodovia Presidente Dutra ou pela estrada RJ-139, a partir de uma estrada secundária entre elas, passando por Arrozal.

\subsection{Materiais e Métodos}

Os materiais e métodos utilizados neste trabalho encontram-se descritos em detalhe no APÊNDICE, sendo ai caracterizadas as metodologias utilizadas nos trabalhos de campo (cartografia geológica), na aquisição e tratamento dos dados estruturais, geofísicos, geoquímicos, de química mineral, geoprocessamento, modelagem dinâmica e nomenclatura adotada.

\subsection{Contexto tectônico de geraçăo de granitóides}

A ocorrência de expressivo volume de magmatismo granítico em cinturões orogênicos tem sido explicado com base em três principais modelos geodinâmicos: (i) modelo de arco magmático associados com subducção de litosfera oceânica; (ii) modelos de colisão arco-de-ilha/continente ou continente/continente e, (iii) modelo intraplaca, onde o regime predominante é a extensão crustal.

Estes modelos equivalem a divisão proposta por Lagarde et al. (1992), onde os granitos são divididos em quatro grandes grupos: (i) granitos oceânicos; (ii) granitos intraplaca; (iii) granitos de arco magmático e, (iv) granitos de colisão. Estes quatro grupos, na 
realidade, podem ser reduzidos a dois contextos geodinâmicos maiores: (1) contexto de zonas de divergência, oceânica (plagiogranitos oceânicos), continental e intra-placa; (2) contexto de zonas de convergência, oceânica ou continental, incluindo subducção (granitos de arco) e colisão (granitos colisionais).

Em zonas de convergência continental, de colisão continente-continente, o magmatismo granítico resultante apresenta características que refletem a interação de massas continentais envolvidas, sendo esperado uma abundância de granitos tipo-S, a exemplo do que ocorre nas cadeias hercinicas e himalaianas, com natureza do magmatismo sendo avaliada com base em diagramas discriminantes de elementos maiores e traços (Lameyre \& Bowden 1982; Pearce et al. 1984; Harris et al. 1986). A distinção entre os granitos sin, tardi e pós-colisionais, tem sido feita também com base nesses diagramas.

Em zona de colisão são distinguidos três estágios sucessivos de geração de granitos: (i) estágio de convergência continental com espessamento da litosfera, (ii) estágio pós-espessamento litosférico e, (iii) estágio de divergência continental - ou estágio final - também referido como estágio extensional.

Os granitos formados durante o primeiro estágio são referidos como granitos orogênicos de colisão, sejam eles formados durante ou após o espessamento crustal. Finalmente, são formados aqueles do estágio de divergência continental, também denominados pós-orogênicos ou pós-colisionais.

A cinemática de convergência de placas, juntamente com sua geometria e heterogeneidades herdadas ou adquiridas pela crosta continental são fatores que condicionam a nucleação e o desenvolvimento de zonas de alta deformação, levando ao desenvolvimento de cinturões orogênicos com características cinemáticas definidas pelas zonas de cisalhamento principais (Vauchez 1987).

\subsubsection{Granitóides e suas encaixantes}

O alojamento de granitos desempenha relevante papel na evolução tectônica de cinturões orogênicos, contribuindo assim como um elemento importante na história deformacional dos mesmos (Hamilton \& Myers 1967).

Estudos recentes sugerem que a ascensão de magma granítico desencadeia períodos de maior deformação. Tais estudos consideram que o tempo relativo de colocação pode ser melhor entendido da seguinte maneira: (i) caracterização da natureza da foliação presente nos granitóides, se de fluxo ígneo (primária) ou 
deformacional (secundária); (ii) relação do padrão estrutural do pluton com da encaixante; (iii) caracterização do mecanismo de colocação que afetou as estruturas do pluton; (iv) determinação das condições físico-químicas e da taxa de deformação nas rochas encaixantes durante a colocação do pluton.

Um estudo sistemático das feições estruturais e metamórficas adjacentes ao pluton deve ser comparado com as estruturas magmáticas e deformacionais do interior do pluton. Além disso, deve considerar a trajetória da foliação em mapa, com vistas ao entendimento da colocação dos granitóides no contexto de zonas de cisalhamento.

As características do magmatismo sincinemático permitem avaliar melhor as relações genéticas entre as zonas de cisalhamento e a natureza do magmatismo. Isto é determinado com base nas idades (relativas e absolutas) entre os eventos metamórficos, deformacionais e magmáticos, juntamente com as características petrológicas da intrusão (fusão crosta/manto, etc.).

Estudos realizados por Burg (1987), com base em indicadores cinemáticos, demonstram que o padrão simétrico da foliação externa ao pluton não está relacionado ao metamorfismo regional, mas sim ao modelo de alojamento forçado do pluton. Por outro lado, alguns autores consideram que este tipo de foliação associa-se predominantemente à deformação regional (Paterson et al. 1991), enquanto outros consideram a combinação entre a deformação regional mais aquela relacionada com o alojamento do pluton (Hutton 1982, 1988).

\subsubsection{Regimes transpressionais e distensionais}

Quando blocos crustais são deslocados por zonas de falha ou de cisalhamento, com componentes oblíquas, surgem os denominados regimes transpressionais e distensionais, os quais são caracterizados por um conjunto de estruturas associadas (Harland 1971; Sanderson \& Marchini 1984; Fossen \& Tikoff 1993).

Assim, o regime transpressivo é controlado por um modelo de deformação tangencial oblíqua, que permite o desenvolvimento simultâneo de estruturas de baixo e de alto ângulo. As estruturas de baixo ângulo são geradas predominantemente por cisalhamento simples e representam um primeiro estágio da deformação, enquanto as de alto ângulo, associada à transcorrência, representam um estágio mais tardio. Esta combinação de diferentes mecanismos de deformação é conhecida na literatura como partição da deformação (Lister \& Willians 1983; Tikoff \& Tessier 1984; Richard \& Cobbold 1990). 
Nas zonas transpressivas ocorrem várias estruturas, tais como foliações em leque, falhas com movimentos inversos e obliquos, duplexes transcorrentes-contracionais, dobras com pequeno ânguio em relação às zonas de cisalhamento, zonas de cisalhamento dúcteis menores, antiformes e sinformes assimétricos.

Este regime promove espessamento crustal e acomoda a ejeção de material da crosta inferior para crostas média e superior, seja na forma de dobras, de estruturas emflor positivas, cavalgamentos, extrusão de fluídos e de magmas ou produtos de fusão parcial (Mc Caffrey 1992; Ebert 1995).

Estruturas em-flor positivas são condicionadas no limite crosta superior/inferior, ou nas partes mais profundas onde elas são invertidas (Mc Caffrey 1995). São importantes feições estruturais que conjugam falhas transcorrentes e de empurrão, com a primeira delas sendo gerada por um mecanismo de cisalhamento simples (direção $X$ da elipse de deformação), e a segunda por um mecanismo de cisalhamento puro (plano $Y-Z$ ), resultando assim em encurtamento crustal em regime transpressivo (Harland 1971; Sanderson \& Marchini 1984; Fossen \& Tikoff 1993). Neste tipo de estrutura ocorre transporte de material das regiões de alta deformação para de baixa deformação ( $M c$ Caffrey 1992).

Corpos plutônicos alojados em ambientes distensivos tendem a exibir características peculiares e marcantes, como formas irregulares e circulares, estruturas maciças, baixo grau de orientação planar e de deformação mineral, abundância de microestruturas no estado sub sólido, podendo ainda exibir orientação vertical de cristais em resposta ao diapirismo ou baloneamento.

Em segmentos transpressivos, por estarem sujeitos ao cisalhamento simples e puro simultâneos, podem criar condições para o alojamento de corpos fortemente orientados e com deformação no estado sólido, cuja disposição final é compativel com o elipsóide de deformação finita regional (achatamento vertical e estiramento horizontal). Paralelamente, ocorre também desenvolvimento de foliação milonítica (Mc Caffrey 1992).

O movimento entre blocos crustais ou litosféricos em regime transcorrente requer, necessariamente, o enraizamento em profundidade das zonas de cisalhamento de alto ângulo em zonas de baixo ângulo.

Ebert 1995 conclui que a existência de descontinuidades é essencial para promover a migração de magmas, e que o contraste de viscosidade entre o magma e rocha encaixante é mais importante do que o equilíbrio isostático para a mobilização de corpos plutônicos. Assinala também que a componente compressiva atua como motor que impulsiona os magmas ao longo das zonas de cisalhamento transcorrentes, os quais 
respondem como um meio rápido para aliviar as tensões em direção à superficie. Para o autor, ocorre o congelamento subseqüente do magma durante a sua ascensão e não a geração de espaços como nos ambientes trativos.

Estudos com modelagem numérica e física indicam, por outro lado, que o strain no estágio dúctil associado ao modelo diapírico deve ser muito elevado, com achatamento superior a $90 \%$ e extensão muito acima de 100\% (Dixon 1975; Crunden 1988), principalmente quando a rocha encaixante encontra-se em condições de temperatura e viscosidade médias, que é o caso mais comum encontrado na crosta.

Mc Connel (1969), com base em estudos de laboratório, sugere um modelo de geração de granitos por calor friccional ao longo de planos de deslizamentos, em zonas de intenso cisalhamento, onde a temperatura local pode atingir $700^{\circ}$ a $800^{\circ} \mathrm{C}$, que é compatível com o valor esperado para a fusão diferencial para magma granítico (Tuttle \& Bowen 1958). Contudo, não devem ser negligenciados parâmetros como viscosidade, velocidade de deslizamento e shear stress ao longo dos planos de cisalhamento.

\subsubsection{Análise estrutural de plutons graniticos}

Um estudo sistemático dos aspectos estruturais e metamórficos adjacentes aos plutons graníticos deve levar em conta o reconhecimento e a caracterização de estruturas de fluxo magmático e deformacional nas rochas granitóides, bem como a sua trajetória em mapa.

A trajetória dos planos de deformação fornece informações importantes entre a tectônica e o magmatismo (Ledru \& Brun 1977; Brun \& Pons 1980, in: Corrioux 1983).

Estas duas foliações, uma vez plotadas em mapa estrutural (APÊNDICE 2), fornecem a trajetória da deformação. Esta trajetória mostra que a evolução da orientação das estruturas de fluxo magmático é controlada pela atividade da zona de cisalhamento, a qual promove progressivamente seu paralelismo com a direção de cisalhamento.

A foliação milonítica (foliação secundária) desenvolve-se com decréscimo progressivo do valor angular entre a foliação-S e a foliação-C, relação esta que é acompanhada por um aumento importante do processo de milonitização da rocha.

Em plutons alojados sintectônicamente, a foliação pode mostrar ou um padrão contínuo com a foliação regional (Brun \& Pons 1981; Vigneresse 1980), ou ela pode sofrer uma inflexão no contato com a encaixante, registrando neste caso diferentes valores de strain (Hutton 1988a).

As foliações destes plutons, deformados ou não, e alojados por diferentes mecanismos, indicam que a colocação ocorreu sob condições de fluxo magmático. 
A foliação magmática forma pode formar ângulo com a foliação das rochas encaixantes ou pode ser contínua com a foliação desenvolvida na borda do corpo (Holder 1979; Batteman 1988), sugerindo neste caso um desenvolvimento tardio ao seu alojamento.

Outro elemento estrutural importante para interpretar a colocação de corpos graníticos em zonas de cisalhamento é a lineação mineral ou de fluxo linear em geral, formadas pelo arranjo de minerais como biotita, anfibólios, feldspatos e quartzo, ou pela presença de agregados máficos na forma de "schlierens" ou de enclaves microgranulares. Tais estruturas, têm sido assim caracterizadas:

a) lineacões minerais contidas na superficie do fluxo magmático são constantemente representadas por feldspatos alcalinos (Marre 1973; Pons 1975; Fernandez \& Tempier 1977; Blanchard et al. 1979). O quartzo apresenta-se concentrado em determinados locais, com forma alongada e paralela ao fluxo magmático;

b) foliaç̃es horizontais no interior de corpos graníticos são geralmente explicadas pelo mecanismo de colocação dos mesmos;

c) as microestruturas observadas no quartzo sugerem predomínio de mecanismos de recristalização dinâmica (estado sub sólido), associados a mecanismos por migração de defeitos ou fraturas (Guillopé \& Poirier 1979, in: Corrioux 1983);

d) em zonas milonitizadas, as lineações nas rochas encaixantes variam desde verticais, ao longo da borda de um corpo intrusivo (p.ex. diápiro), até lineações horizontais, podendo estas estruturas desaparecerem para o topo (Dixon 1975; Ramberg 1981);

e) a lineação de estiramento mineral e os indicadores cinemáticos fornecem informações valiosas sobre a direção de fluxo magmático e fluxo no estado sólido, bem como sobre a deformação da rocha encaixante (Brun \& Pons 1981; Burg 1987). Brun et al. (1990) sugerem que as lineações de estiramento horizontais paralelas às margens dos plutons podem representar a expansão dos mesmos, enquanto padrões complexos definem a peneconteporaneidade do alojamento com a deformação regional (Brun \& Pons 1981).

Em resumo, constata-se do acima exposto que o conhecimento da trajetória das estruturas planares (foliação de fluxo magmático e deformacional) e lineares (lineação mineral no estado magmático e no estado sólido) é fundamental para o entendimento da colocação de rochas granitóides associadas a zonas de cisalhamento, de alto ou baixo ângulo. Adicionalmente, o comportamento em mapa destes elementos facilita a visualização da geometria do corpo e sua relação com as zonas de cisalhamento adjacentes. 


\subsubsection{Mecanismos de colocação de magmas graníticos}

Coube a Buddington (1959) a proposição de dois mecanismos básicos para colocação de corpos magmáticos: (1) forçada, onde o corpo empurra lateralmente a rocha encaixante, e (2) passiva, onde a rocha encaixante permite passivamente a passagem o fluxo magmático.

Posteriormente, estes mecanismos foram aprimorados e subdividos, sendo porém mantidos a subdivisão nestes dois tipos básicos: forçado, incluindo domos, diápiros e baloneamento; passivo ou permissivo, envolvendo stoping, subsidência de caldeiras e sheeting (Hutton 1988; Jardim de Sá 1984; Castro 1987).

O diapirismo é um mecanismo de colocação característico de crosta média a inferior, que apresenta aspectos peculiares. Neste modelo, a ascensão de magmas graníticos está intimamente relacionada com trocas de calor entre o magma e a encaixante, com o magma comportando-se como um líquido viscoso. Aqui a ascensão do magma granítico ocorre enquanto houver capacidade em liberar calor, mantendo assim a temperatura ao redor do corpo.

Embora modelos experimentais, simulando a colocação de domos salinos, tenham fornecido informações importantes para o entendimento de estruturas diapíricas, alguns aspectos são difícil de ser reproduzidos em laboratórios, a exemplos das fraturas desenvolvidas na parte superior do pluton, restringindo assim a aplicação deste tipo de modelo.

A subsidência de caldeiras e stoping são modelos geralmente associados ao nível crustal raso, onde às condições reológicas das rochas encaixantes são compatíveis com comportamento rúptil, possibilitando assim o deslocamento do magma através de fraturas.

Os mecanismos mais aceitos para explicar a colocação de magmas graniticos em níveis crustais profundos são: enxame de diques e pulsos múltiplos, na forma de diques ou sheets sub verticais, alimentando corpos tabulares horizontalizados situado acima, ou seja, em níveis crustais mais rasos (Hutton 1992; Brouw 1994; Rubin 1995; Vigneresse 1995; Castro 1987).

Os magmas graníticos, em estágios mais avançados, alcançam regiões superiores da crosta através de fraturas profundas ou geossuturas $(\sim 40 \mathrm{~km})$, sendo aí representadas por zonas de cisalhamento dúcteis de alto ângulo. 


\subsubsection{Fatores de controle da colocaçăo de magmas graníticos}

A força de ascensão do magma é um dos fatores mais importantes no controle de colocação de magmas graníticos. Esta força é função dos seguintes parâmetros: pressão hidrostática específica a uma profundidade considerada, força de compressão sobreposta e força de flotação devido ao contraste de densidades.

Deve também ser considerado que o campo de stress próximo ao corpo é o resultado da soma do stress regional com o stress local. Além disso, o efeito da profundidade está intimamente vinculado às variações de viscosidade do sistema magma-rocha encaixante, sendo aqui mais influenciado pela composição, temperatura e presença de fluídos, do que pela profundidade e pressão propriamente ditas (Hutton 1988).

Quando o stress é baixo, a ascensão do magma é controlada somente pela flotação (separação de partículas em estado sub sólido) e viscosidade do material fundido. Forças verticais, assim como sucção ou compactação são influências positivas menores. A deformação regional é considerada como uma força externa que pode induzir a segregação do magma.

$\mathrm{Na}$ presença de cisalhamento, as forças não hidrostáticas atuam como forças dirigidas. O cisalhamento, neste caso, age como força positiva que atua na segregação dos magmas. A deformação não causa fusão ou geração de magmas graníticos, muito menos é uma condicionante local para a sua ascensão.

Os plutons graníticos são considerados como resultados da deformação, uma vez que a segregação e ascensão de magmas graníticos são controlados pelo campo de deformação (Vigneresse 1995b). Para o autor, a maior barreira para a ascensão de magmas é a zona de transição da crosta dúctil/rúptil. Isto ocorre por volta de $400^{\circ} \mathrm{C}$, para uma crosta rica em feldspato e, em torno de $300^{\circ}$ a $350^{\circ} \mathrm{C}$, para uma crosta rica em quartzo.

A temperatura de transição é independente da taxa de strain, e possui um pequeno efeito ao nível de strain requerido para o fraturamento da crosta. Em crosta rígida, é ao redor de 150 - $200 \mathrm{Mpa}$., com estes valores podendo ser 2 ou 4 vezes maior, no caso de falhas direcionais ou de empurrão (Vigneresse 1995a).

O stress requerido para fraturar uma crosta rígida é quatro vezes maior sob condições de compressão do que sob extensão. Consequentemente, em termos mecânicos, os locais mais propícios para a intrusão de magmas na crosta são as áreas extensionais. Contudo, isto não implica que os granitos possam ser intrusivos somente 
em áreas extensionais, pois em conseqüência de variações dos campos de stress, regional ou local, ou da partição da deformação, haverá sempre alguma extensão local. Deve-se também considerar que o regime de deformação se altera e é variável no espaço e no tempo.

Estudos recentes têm relacionado o alojamento de plutons a eventos predominantemente contracionais, com dobras e falhas de empurrão associadas (Brun \& Pons 1981; Castro 1986; Hollister \& Crawford 1986; Miller et al. 1988; Paterson et al. 1991).

Hutton (1995) relaciona alguns exemplos brasileiros de granitos alojados em zonas de cisalhamento ou cinturões orogênicos contracionais. O autor salienta que a maioria destes exemplos são relacionados com segmentos transpressivos. Destaca a expressiva quantidade de granitos Proterozóicos dispostos ao longo dos $2000 \mathrm{~km}$ do cinturão Ribeira.

No Brasil, um exemplo notável disso, têm sido evidenciado a partir de estudos sobre a granitogênese Brasiliana da Província Borborema, no nordeste brasileiro (Archanjo et al. 1992; Jardim de Sá et al. 1993 e 1995; Jardim de Sá 1994; Trindade et al. 1995; Borges et al. 1995; Pacheco Neves 1995).

Um aspecto importante, discutido por vários autores, é o problema do espaço em profundidade para colocação de magmas graníticos. Isto começou a ser investigado por Bowen (1948). Desde então, considera-se que a abertura de espaços é devido a processos tectônicos, sendo este um fator fundamental no controle da migração e alojamento de magmas na crosta. Esta situação não é exclusiva de níveis rasos da crosta (comportamento predominantemente rígido), mas opera também em níveis mais profundos e até mesmo no manto litosférico. Numa primeira análise, alguns regimes tectônicos mostram-se desfavoráveis para a colocação de rochas granitóides. Contudo, situações específicas, em diferentes escalas, podem favorecer a abertura desses espaços, permitindo assim a passagem e alojamento dos magmas graníticos. Neste caso, a pressão de fluídos do magma (magma pumping) passa a exercer um papel importante.

O controle e alojamento de plutons graniticos em sistemas transcorrentes tem sido sistematicamente referido na literatura (Hutton \& Reavy 1992). Neste contexto, a colocação de magmas graníticos encontra-se vinculada ao quadro tectônico regional e neste sentido uma avaliação da deformação nesta escala torna-se muito importante, devendo ela ser considerada junto com a deformação local.

A presença de expressivas massas graníticas alojadas em regiões adjacentes às 
zonas de cisalhamento sugere a existência de canais de alimentação situados próximos das regiões sujeitas a altas taxas de deformação, o que torna difícil desvincular a coexistência lateral entre ambientes tectonicamente diferentes.

Em niveis profundos da crosta, a separação de magmas a partir de fontes crustais pode ocorrer por fluxo magmático favorecido por dilatação, com migração de magma paralela a direção de menor stress compressivo (eixo X).

O reconhecimento de estruturas de fluxo magmático e fraturas em plutons graníticos sintectônicos pode auxiliar no entendimento da cinemática da intrusão. Sabese, por exemplo, que magmas viscosos podem ser deformados, mudando de forma e dimensão durante sua ascensão. Como resultado, a parte interna do corpo pode preservar a natureza do movimento ascensional, enquanto a parte externa preserva sua trajetória.

\subsubsection{Geometria}

Em duas dimensões, muitos plutons são arredondados ou elípticos, mostrando zonamento composicional e foliações concêntricas. Outros, são achatados e exibem uma geometria em forma de elipse, e embora tenham características de alojamento forçado, desenvolvem muitas vezes uma nova foliação sobreposta.

Estes plutons têm sido interpretados como diápiros oblíquos ou em cogumelo (Corrioux 1987; Jackson \& Talbot 1989). Eles podem penetrar diápiros ou baloneamentos mais antigos.

Corpos graníticos sintectônicos tendem a ser alongados, paralelos ou sub paralelos à foliação regional (Hutton 1982; Paterson \& Tobisch 1988). Conforme referido anteriormente, a caracterização da natureza da foliação é fundamental para a discussão do caráter tectônico do corpo, pois os plutons pré- e pós-tectônicos podem também ser alongados e paralelos à foliação regional (Castro 1987).

A forma dos plutons pré- e sintectônicos influenciam enormemente no padrão estrutural da deformação subseqüente. As zonas de cisalhamento dúcteis instalam-se ao longo das margens de plutons pré-tectônicos e desenvolvem, no estágio final de seu alojamento, sombras de pressão (Oliver \& Wall 1987; Paterson \& Tobisch (1988). Tais plutons, podem ser afetados por falhamentos pós alojamento (Lamouroux et al. 1980).

A morfologia dos plutons em profundidade, bem como a posição e número de zonas enraizadas, varia de acordo com o tipo de deformação, sugerindo ainda a importância da deformação regional no seu controle. São ainda importantes as condições termais e o regime de deformação da crosta. Deste modo, a 
estrutura crustal, juntamente com a composição petrológica, nivel crustal de colocação, disponibilidade de calor gerado e controle das condições termais da crosta são fatores determinantes na morfologia resultante dos corpos graníticos (Vigneresse 1995b).

Em resumo, a morfologia dos granitos em profundidade é controlada pelo campo de stress regional, sobretudo quando eles ainda estão pouco densos. Possuem aproximadamente 5 a $2 \mathrm{~km}$ na fase compressional, passando para 2 a $3 \mathrm{Km}$ na fase extensional (Vigneresse 1995b).

\subsection{Fluxo Magmático: Conceito e tipos}

Existem ainda controvérsias sobre os critérios usados para a distinção entre foliacões formadas por processos tectônicos ou magmáticos. Considera-se esta distinção fundamental para o entendimento da colocação dos plutons graníticos e do tempo envolvido. Isto auxilia na interpretação da idade e significado destas estruturas, bem como de suas relações com o metamorfismo regional (Castro 1987, Berguer \& Pitcher 1970).

Fluxo magmático é definido como a deformação gerada pelo deslocamento do magma, como resultado da rotação de corpos cristalinos rígidos, sem a interferência entre os cristais de modo a causar a deformação plástica (ou seja, suspensão de material sólido em meio com comportamento físico-químico favorável).

Em um magma, o limite crítico de condutos ou caminhos de material em fusão - ou pequenas fraturas - é considerado em torno de 20\% de volume (Arzi 1978; Van der Molen \& Paterson 1979), podendo entretanto aumentar para $50 \%$ de volume sobre as mesmas circunstâncias (Vernon 1989).

O desenvolvimento da foliação em rochas granitóides pode ser contínuo entre os estados magmáticos e estado sólido. Portanto, a distinção entre elas nem sempre é uma tarefa fácil. Em função disso, recomenda-se a combinação de critérios petrográficos e estruturais (micro e macro).

Paterson et al. (1989) dividiu estes processos em quatro estágios: (i) estágio de fluxo magmático (estágio com comportamento semelhante à suspensão), (ii) estágio de fluxo sub magmático (fluxo menor que a quantidade crítica de fundido por fluxo magmático); (iii) estágio de fluxo no estado sólido em alta temperatura (deformação plástica em sub sólido) e, (iv) estágio de fluxo no estado sólido em condicões de média ou baixa temperatura.

O fabric por fluxo magmático envolve uma taxa de cristalização mais baixa (entre 
30 e $40 \%$ ), enquanto fluxo sub magmático esta taxa é mais avançada e pode atingir até $75 \%$. Para taxas de cristalização superiores a $75 \%$, o fabric de deformação é de alta temperatura ("subsolidus plastic deformation"), aparecendo no mesmo feições do estado sólido e do estado plástico (Paterson et al. 1989, Hutton 1988).

Neste último caso, os megacristais de feldspatos são alinhados e podem apresentar deformação das geminações e fraturamentos. O quartzo apresenta forma lenticular e extinção ondulante, podendo a deformação evoluir para formação de sub grãos. Assim, a geração de um fabric no estado sólido implica numa origem tectônica para o mesmo. Observam-se nele minerais metamórficos alinhados com feições características de deformação no estado sólido.

De forma geral, leva-se em conta apenas dois estados principais de fluxo: magmático e sólido. Com isso, torna-se mais fácil a utilização dos critérios para a descrição de fabrics encontrados em plutons sintectônicos.

Para a análise da geração de foliações em granitóides deve-se considerar os seguintes aspectos: natureza e estrutura do granitóide; relação entre o padrão cinemático das estruturas do pluton e das rochas encaixantes; caracterização do mecanismo de alojamento que afetou estas estruturas; relação entre as estruturas das rochas encaixantes e os porfiroblastos, datação de minerais ou rochas que representam a fase ígnea e metamórfica; definição da forma do pluton, contraste de viscosidade com a rocha encaixante, condições físicas e taxa de strain decorrentes da deformação regional durante seu alojamento.

Muitas destas foliações têm sido definidas em granitóides, aparentemente isotrópicos, usando alinhamento estatístico de feldspatos (Balk 1937; Marre 1986; Hood \& Shaw 1987), ou com base em dados de anisotropia de susceptibilidade magnética (Guillet et al. 1983; Rathore \& Kafafy 1986).

A intensidade da foliação magmática aumenta em geral para as bordas dos corpos, sendo aí marcada pela orientação preferencial de minerais ou de enclaves alongados (Pabst 1928; Bateman et al. 1963, Pitcher \& Berger 1972; Raciot et al. 1984; Castro 1986; Marre 1986; Frost \& Mahood 1987; Vernon et al. 1988). Porém, em alguns casos pode mostrar variações complexas (Buddington 1959; Pitcher \& Berger 1972; Corrioux 1987).

\subsubsection{Evidências meso e microestruturais do fluxo magmático}

O critério principal para a determinação de fluxo magmático é a orientação preferencial da forma de minerais primários, que não mostram evidências de deformação 
plástica ou recristalização de cristais alinhados ou intersticiais.

Este critério é válido quando os minerais orientados são feldspatos (plagioclásio ou feldspato alcalino euedral), pois eles crescem como cristais euedrais em rochas metamórficas não fundidas (Vernon 1968, 1976, 1986; in: Paterson 1989). Para explicar o alinhamento ou formas cristalinas, consideram-se os seguintes aspectos:

1. A origem ígnea é favorecida especialmente quando o alinhamento de cristais de feldspatos mostra microestruturas igneas (como synneusis, zonamento oscilatório, etc.) não separados por agregados recristalizados;

2. Cristais magmáticos orientados envolvidos por grãos ou agregados de quartzo anédrico, não deformados e não orientados. Neste caso, o quartzo ou agregados de quartzo não apresentam orientação preferencial. Contudo, quando isso ocorre, a deformação do quartzo sobrepõe-se a deformação plástica e promove o rearranjo cristalino, produzindo o alongamento preferencial deste mineral, enquanto os demais não são afetados (para uma determinada $P, T, P$ fluídos, etc.). Este tipo de situação é entendido como um indicador discreto de fluxo no estado sólido (Vauchez 1980; Marre 1986; in Paterson et al 1989);

3. Imbricação ou entelhamento de cristais (Den Tex 1969) ocorre quando a rotação dos cristais se desenvolve em fluído viscoso. A curvatura das linhas de cristais de feldspatos pode ser observada em veios graníticos e relacionadas ao seu arraste nas bordas com as encaixantes durante o fluxo magmático (Blanchard et al. 1979);

4. Medidas de anisotropia da susceptibilidade magnética revelam orientação em granitóides não deformados. O K1 máximo da anisotropia é paralelo a lineação mineral gerada pelo fluxo magmático. Porém, deve-se ter precaução quanto ao alinhamento magnético, pois ele pode também ocorrer durante a deformação (Hrouda \& Janak 1976; Guillet et al. 1983; Archanjo et al. 1992);

5. Orientação preferencial de enclaves microgranulares alongados tem sido interpretado como magmas em forma globular ou em bolsões, cuja solidificação foi incompleta, razão pela qual não mostram evidências de deformação plástica ou recristalização em seu interior (Bateman et al. 1983; Vernon 1983; Vernon et al. 1988);

6. A foliação de fluxo magmático sofre deflexão freqüente ao redor de enclaves de microgranitos e de xenólitos metassedimentares;

7. Acamamento magmático marcado por estruturas tipo schlieren é outro importante indicador de fluxo magmático. Contudo, pode ocorrer fluxo seletivo anterior por mecanismo de seleção gravitacional, que vai refletir igualmente a direção do fluxo magmático (Bateman et al. 1963); 
8. Quando o acamamento magmático é produzido por fluxo magmático paralelo às rochas encaixantes, os megacristais e enclaves tornam-se raros próximo ao contato, passando porém a ser abundantes poucos metros para o interior do corpo (Reesor 1958).

\subsubsection{Evidências micro e meso estruturais de fluxo no estado sólido}

1. Os grãos minerais mostram evidências microscópicas de deformação plástica como extinção ondulante, kink bands em feldspatos e micas, maclas em cunha em feldspatos, recuperação de quartzo como sub grãos ou recristalizados como grãos menores, incluindo feldspatos e mica fina em agregados. Estes agregados podem ser monominerálicos ou poliminerálicos, neste caso, quando envolverem reações metamórficas (neocristalização) (Vernon et al. 1983);

2. Redução simultânea de grãos e estiramento em agregados finos, com recristalização do quartzo em ribbons ao longo da foliação, juntamente com agregados lenticulares de mica branca e titanita, neoformação de biotita e mirmequitas recristalizadas (Vauchez 1980; Bateman et al. 1983; Vernon et al. 1983; Simpson 1985);

3. Presença de megacristais de feldspatos ou hornblenda, fraturados e boudinados, juntamente com fitas de mica e quartzo recristalizados dispostos ao longo de fraturas ou em porções mais estiradas dos boudins (necks) (Vernon et al. 1983; Simpson 1985);

4. Inversão do ortoclásio para microclínio ocorrida por deformação no estado sólido (Eggleton \& Buseck 1980);

5. A foliação metamórfica é normalmente contínua nos enclaves, quando a viscosidade é semelhante entre a rocha encaixante e o granitóide. Contudo, se houver diferença composicional e textural significativas, pode ocorrer refração da foliação;

6. Veios aplíticos podem aparecer dobrados, com a foliação sendo paralela ao plano axial das dobras. Este critério é duvidoso, pois o fluxo magmático pode gerar dobras e foliações no granito encaixante;

7. Como strain é heterogêneo, pequenas zonas miloníticas podem ser desenvolvidas (Choukroune \& Gapais 1983; Vernon et al. 1983);

8. Em rochas granitóides, duas foliações podem ocorrer como orientações conjugadas (Choukroune \& Gapais 1983), ou como planos S-C (Berthé et al. 1979; Choukroune \& Gapais 1983; Vernon et al. 1983; Lister \& Snouke 1984). Neste último 
caso, o ângulo entre estas duas foliações tende a se reduzir com o incremento da deformação;

9. Evidências de dissolução cristalina podem ser associadas ao desenvolvimento de foliação no estado sólido (Kernich et al. 1980; Burg \& Ponce de Leon 1985).

\subsubsection{Fluxo magmático $X$ Fluxo deformacional:}

\section{$\checkmark$ Critérios de separação}

Vários autores sugerem que o fluxo magmático grada continuamente para o fluxo no estado sólido, sendo isto observado nas bordas de plutons diapíricos deformados posteriormente por baloneamento, com a porção interna dos mesmos permanecendo sob a ação de forças de flotação (Holder 1981; Ramsay 1981; Bateman 1985; in Paterson 1989). Contudo, isto pode ocorrer por encurtamento tectônico (Castro 1987), e neste caso apresentam evidências microestruturais como:

1. Deslizamento ao longo do plano " $\mathrm{C}$ " do quartzo (deslizamento paralelo ao eixo $\mathrm{C}$ do quartzo, com formação sub grãos basais) ocorre em condições de alta temperatura, entre $650^{\circ}$ a $750^{\circ} \mathrm{C}$, em condições hidratadas, indicando que a deformação plástica ocorreu próxima da temperatura da linha que separa o solidus granítico (Blumenfeld et al. 1986; Gapais \& Barbarin 1986; Mainprice et al. 1986). Alguns autores, porém, consideram que este tipo de deslizamento no quartzo pode ocorrer também em baixas temperaturas (O'Hara \& Gromet 1985);

2. A existência de grãos de quartzo alongados segundo o eixo $\mathrm{C}$, em granitóides fracamente deformados, tem sido relacionada à direção de estiramento local (Gapais \& Barbarin 1986). Os autores salientam que o ângulo entre o eixo $C$ e a direção de estiramento local aumenta com o decréscimo do tamanho dos grãos fortemente recristalizados;

3. A recristalização do feldspato necessita de temperaturas acima de $450^{\circ} \mathrm{C}$, em condições normais de taxas de strain (Tullis 1983);

4. Exsolução de lamelares de albita em feldspato alcalino recristalizado indica temperaturas de recristalização acima da linha do solvus deste último (Vernon et al 1983);

5. Presença de pares de foliações S-C que indicam o sentido do cisalhamento, juntamente com imbricação de cristais de feldspatos que permitem inferir o fluxo magmático (Blumenfeld 1983; Blumenfeld \& Bouchez 1988);

6. Presença de minerais magmáticos tardios em sombras de pressão, indicando 
transferência de pequenas quantidades de material fundido durante a deformação do granito (Gapais \& Barbarin 1986; Hibbard 1987).

O primeiro e terceiro critérios indicam que a deformação ocorre em temperaturas próxima da linha do solidus. Entretanto, é necessário determinar o momento que ocorreu a deformação ou a recristalização, bem como se ela foi durante o resfriamento magmático ou durante um aquecimento tardio (Vernon et al. 1983).

Alternativamente, os grãos maiores de quartzo podem crescer a partir de uma solução em uma direção paralela ao alongamento principal ou eixo C. Embora alguns critérios evidenciem deformação em granitos em temperaturas próximo à linha do solidus, eles não indicam a transição de magmas deformados no estado sólido.

A deformação em granitóides por fluxo sub magmático encontra-se registrada em microfraturas, pois no estado magmático tardio ocorre sobre crescimento de plagioclásio ou feldspato potássico em sombras de pressão (Hibbard 1987). Aqui pode ocorrer também a cristalização de mirmequita, sugerindo a migração de magmas para zonas de baixo strain. $O$ autor menciona ainda presença freqüente de mirmequitas formadas pela cristalização de magmas saturados em água, em resposta a pequenas mudanças de pressão durante a deformação. Esta hipótese difere daquelas tradicionais que postulam o rearranjo do feldspato alcalino no estado sólido. Contudo, mirmequitas têm sido observadas em granitóides que foram deformados após a solidificação, não havendo portanto evidências de um desenvolvimento exclusivo a partir de um fundido.

Para alguns autores, a presença de mirmequitas e agregados quartzo-feldspáticos recristalizados indica deformação no estado sólido em vez da presença de um fundido anatético (Vernon et al. 1983; Simpson 1985 e Simpson \& Wintsch 1985).

São registrados também em granitóides deformados mirmequitas em forma de lóbulos que ultrapassam as áreas poligonizadas de feldspato e quartzo, sugerindo que alguns grãos de quartzo teriam atuado como bolhas (Vernon et al. 1983, Simpson $1985 \mathrm{e}$ La Tour 1987). Hibbard 1987 denomina estes agregados como "microaplitos" e considera sua cristalização a partir de fundidos.

Evidências de fluxo magmático discutidas recentemente por Paterson (1998) e Vernon (1999) são definidas por: (a) orientação sub paralela de cristais euedrais alongados (p.ex. feldspatos ou hornblenda) não deformados internamente, (b) imbricação (tiling) de cristais euedrais alongados não deformados interiormente, (c) pequena deformação no estado sólido em porções localizadas entre cristais alongados ou imbricados, em virtude da rotação dos cristais, (d) alongamento de enclaves microgranitóides sem deformação plástica dos minerais, (e) foliações de fluxo magmático 
Estas feições são consistentes com a rotação de cristais rígidos, num estágio em que o magma era ainda suficientemente viscoso para preservar a orientação.

As evidências de fluxo no estado sólido incluem: (a) deformação interna e recristalização de grãos, (b) recristalização "em cauda", (c) agregados alongados e recristalizados (p. ex., quartzo e mica), (d) redução no tamanho de grãos, (e) foliação de granulação fina anastomosada ao redor de porções foliadas reliquiares menos deformadas (pods de deformação), (f) microclínio geminado, (g) mirmequita, (h) pertitas em cunha, (i) budinagem de minerais de comportamento rígido, caracterizado por agregados de minerais recristalizados (como quartzo e mica) entre os segmentos de boudins, (j) foliação atravessando o enclave, e ( $k$ ) porções miloníticas localizadas, refletindo a heterogeneidade da deformação.

Os critérios de "fluxo sub magmático" incluem feldspatos recristalizados - inferidos através das transições entre imbricações magmáticas e arranjos tipo S-C no estado sólido - evidências de deslizamentos tipo $\mathrm{C}$ em quartzo, bem como evidências de migração de fundidos residuais em sítios de baixa pressão.

Em condições com baixa porcentagem de fundido, dependendo dos minerais e suas formas, a deformação pode ser acomodada por: (a) dissolução intracristalina acompanhada por deslizamento no contato de grãos, (b) migração do limite de grão dissolvido, (c) partição da deformação em zonas enriquecidas em material fundido, (d) deformação plástica intracristalina (deslizamento tipo $\mathrm{C}$ em quartzo, indicando deformação plástica em temperaturas próximo ao solidus granítico), e (f) transferência de fundidos para locais de baixo stress. A única indicação de deformação com ausência de plasticidade cristalina é o alinhamento de cristais.

\subsubsection{Reologia no estado magmático}

A presença geral de "gotas" intersticiais de magma neoformado, encontrada próximo à Zona de Baixa Velocidade, que se caracteriza pela atenuação sísmica de ondas $P$, é explicada pela formação de lâminas de diferentes relações de forma (r.f.), sendo definida pela equação $r . f$. = largura $/$ comprimento.

Como estas "gotas" podem ser geradas na base da litosfera (topo da astenosfera, profundidade entre 120 e $150 \mathrm{~km}$ ), o magma pode espalhar-se como lâminas com r.f. inferiores a 0,01 e, em proporção muito pequena (da ordem de 1\%).

Esta região é considerada a mais adequada para a geração de magmas, não sendo conclusiva a hipótese de que magmas herdados (herança mantélica) podem ser 
gerados por fusão parcial - contínua ou descontinuamente - durante a história geológica.

No estágio denominado "sólido", Miller et al. 1988 considera que as fases cristalinas se difundem com velocidades em torno de $10^{-14}$ a $10^{-16} \mathrm{~cm}^{2 \mathrm{~s}-1}$, e que o transporte ocorrem com velocidades de $1 \mathrm{~mm}$. por milhão de anos, com temperaturas de 700 a $900^{\circ} \mathrm{C}$.

Para a propagação de magmas, deve existir uma certa quantidade de canais interconectados. Alguns estudos em sistema $\mathrm{CO}_{2}-\mathrm{H}_{2} \mathrm{O}$, em meio líquido, confirmam a presença de fundidos até mesmo com a ausência de canais (neste caso, microfraturas).

Fluidos enriquecidos em $\mathrm{H}_{2} \mathrm{O}$ podem se mobilizar através da crosta em direção à superfície, como o resultado da energia de infiltração direcionada para a superfície (bouyance), sendo isto favorecido pelo fraturamento hidráulico.

Dois típos de infiltração ou percolação são caracterizadas: uma determinada por percolação em cadeia ou vinculada (bond percolation), que é atingida quando ocorre uma conexão na trama cristalina (como por exemplo, dissolução das bordas de grãos durante a fusão incipiente); outra, chamada percolação localizada (site percolation), em que a conexão é casual e ocorre por justaposição.

A análise do comportamento reológico de magmas félsicos, durante ou após a fusão parcial, mostra que ocorrem deslocamentos e segregação de magmas.

Estudos recentes neste sentido introduzem novos limites para a porcentagem de fluidos. O primeiro limite de percolação ocorreria quando filmes de fluídos envolvidos por grãos são interconectados; o segundo limite corresponde ao limite para explicar o escape de fluídos (Vigneresse et al. 1991; Sawyer 1994). Além disso, os autores definem quatro limites que dependem sobretudo da fração fundida presente, do controle de movimento, e da segregação da fase líquida. Para estes autores, os líquidos operam diferentemente para as mesmas condições, durante a fusão parcial e cristalização. Os quatro estágios definidos possuem as seguintes características:

1. porcentagem inicial mínima de $8 \%$ de fundido deve ser produzida para superar - limite mínimo de percolação de um líquido (liquid percolation threshold), onde porções do fundido podem conectar-se e deslocar localmente porções de magmas. $O$ transporte da fase líquida é ampliado pela deformação e pela presença de juntas de dilatação. Além disso, o magma incorpora - em pequena escala - durante sua movimentação materiais pelo caminho. Isto corresponde parcialmente aos domínios incipientes dos fundidos a partir de migmatitos; 
2. Quando o valor atinge $20-25 \%$ de fundido, surge o limite de escape de fundido (mettescape threshold), permitindo assim a segregação e transporte de fundidos através de grandes distâncias, ficando uma porção sólida residual. Isto corresponde a segregação e transferência de magmas que ocorre na crosta superior;

3. Segregação de magmas também ocorre durante o alojamento e cristalização de granitos. Em um fluxo magmático contendo pouca fase sólida - partículas $(\leq 20 \%)$, ocorre a rotação das partículas de forma independente no interior do fluxo, gerando assim o fabric. Com o aumento da fase sólida, as partículas começam a interagir entre si e formam um esqueleto rígido. Cada grupo é composto por uma matriz que envolve aproximadamente $55 \%$ de sólidos, e corresponde ao limite da percolação rígida (rigid percolation threshold). Abaixo deste limite, as partículas podem ainda suportar o stress, enquanto a fração líquida pode então fluir. A maior probabilidade para ocorrer o rearranjo de partículas é em zonas de cisalhamento no interior da intrusão, onde se formam feições de dilatação (expansão). Este estágio de segregação, que ocorre durante a cristalização, é diferente de magmas segregados por fusões incipientes;

4. Finalmente, o sistema gerado de forma compartimentado, solidifica-se quando atinge entre 72 a $75 \%$ de fase sólida, correspondendo assim o limite de fechamento ou de imobilidade das partículas (particle locking threshold).

Quando ocorre a fusão, bolsões de material fundido são conectados, passando então a abrir caminhos para o deslocamento do magma. Com a cristalização, partículas sólidas posicionadas ao acaso passam a interagir mecanicamente.

A presença de uma fase líquida em uma rocha parcialmente fundida modifica enormemente as propriedades reológicas da rocha como um todo. 


\section{CAPITULO 2}

\section{Contexto Geológico-Geotectônico}

Este capitulo contém uma revisão sobre os trabalhos geológicos realizados no Estado do Rio de Janeiro e adjacencias, com ênfase nos trabalhos que abordam o magmatismo granítico Neoproterozóico em termos de contextualização tectónica regional.

\section{Introduçäo}

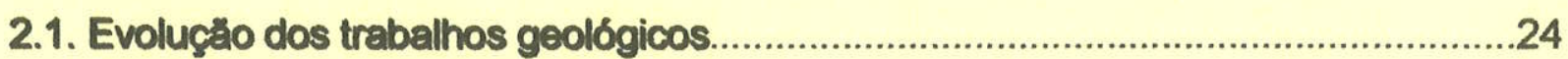

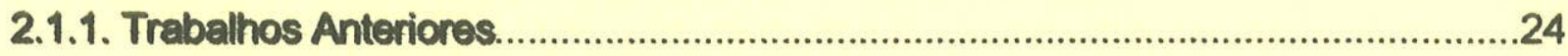

2.1.2. A estrutura tectônica divergente do Vale do Rio Paraíba do Sul........................28

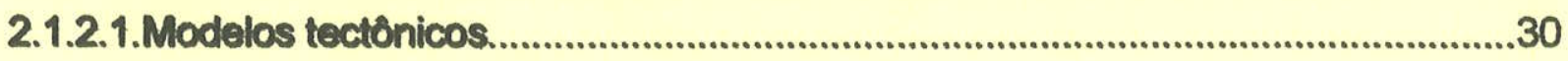

2.1.2.2. Modelos para o magmatismo Neoproterozóico............................................31

2.2. Compartimentaçăo tectônica do Rio de Janeiro..................................................34

2.3. Rochas Granitóides Neoproterozóicas do Rio de Janeiro......................................35

2.3.1. Histórico.

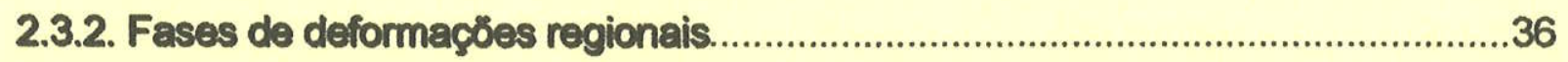

2.3.3. Classificaçăo Tectónica dos granitos no Domínio Paraiba do Sul.......................37

2.4. Compartimentaçăo estrutural na regiăo de Arrozal.................................................38

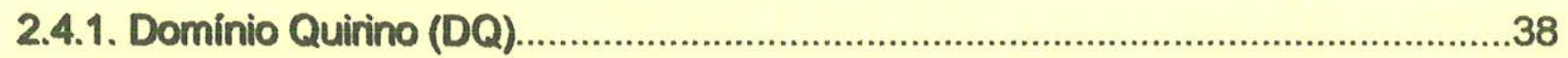

2.4.1.1. Ortognaisses

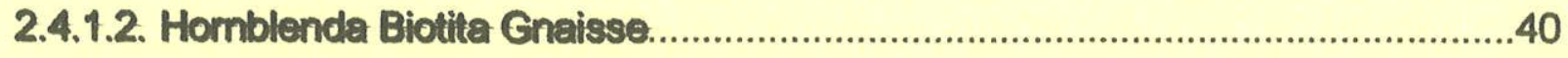

2.4.1.3. Granada Moscovita Biotita Gnaisse ...........................................................40

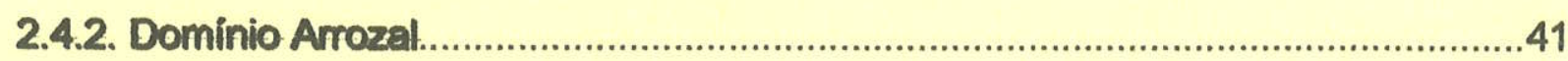

2.4.3. Dominio Serra das Araras........................................................................... 


\subsection{Evolução dos Trabalhos Geológicos}

\subsubsection{Trabalhos Anteriores}

No final da década de 40 começaram, efetivamente, a divulgação dos primeiros trabalhos sobre a região do vale do Rio Paraíba do Sul. Lamego, em 1949, estudando a região entre as Serras da Mantiqueira e do Mar, descreveu a petrografia e a geomorfologia do vale do Paraíba, e correlacionou sua depressão a movimentos tectônicos de caráter epirogenéticos.

Os trabalhos de Ebert $(1955,1956,1968)$ foram indiscutivelmente precursores sobre a tectônica e o metamorfismo das rochas pré-cambrianas do sul de Minas Gerais e Rio de Janeiro, sendo um dos primeiros autores a falar em polaridade tectônica para a região do cinturão Paraiba do Sul entre os dois estados.

Ebert (1955) denominou "Série Paraíba" para as rochas do vale do Rio Paraíba do Sul e chamou a atenção para a intensa adição de potássio (biotitização e microclinização), salientando que esta característica era o traço principal desta série. Paralelamente correlacionou as rochas desta série com as da Série Andrelândia.

Ebert (1956a) considerou os gnaisses encontrados entre Juiz de Fora e o vale do Paraíba como equivalentes em fácies metamórfico (catametamórfico) aos gnaisses algonquianos de Santo Antônio do Porto (MG), região cruzamento entre as estruturas Paraibides e Araxaídes.

Coube a Rosier (1957) o início dos estudos sistemático sobre as rochas précambrianas do estado do Rio de Janeiro, gerando nessa ocasião um esboço geológico de praticamente todo o estado, cujos traços geológicos principais são ainda válidos atualmente. Neste trabalho, define a Série Paraíba e caracteriza para a região um sistema complexo de "nappes" superpostas.

Posteriormente, Rosier (1965) define a Série Paraiba-Desengano, separando as seguintes Faixas e Séries, com suas respectivas situações geotectônicas: Faixa Saquarema-Cabo Frio-Macaé (Pós-País), Faixa Maricá-Conceição de Macabu (borda do geossinclinal), Faixa Rio Bonito-Lumiar, Série Paraiba-Desengano, Faixa Pedra Lisa, Serra dos Órgãos e Faixa Eugenópolis-Caparaó. 
Ebert (1968) considerou a Série Paraiba como sedimentos de características eugeossinclinais, em fácies anfibolito a granulito, correlacionada a Série Juiz de Fora (charnockitos) e aos gnaisses da Serra do Mar e vale do Rio Paraíba do Sul, sendo constituida por metagrauvacas parcialmente conglomeráticas, metarcóseos e, mais raramente, quartzitos e metacalcáreos. Considerou ainda as mudanças sedimentares e metamórficas para explicar a transição entre os Grupos Andrelândia e Paraíba. Esta transição seria definida por uma tectônica superposta com as seguintes características: uma tectônica principal com estruturas imbricadas de "escamas" superpostas, movimentadas de sudeste para noroeste. Estas "escamas" foram desenvolvidas com um dobramento inicial, evoluindo muitas vezes para dobras isoclinais que, finalmente, se degenerariam em um sistema de falhas de empurrão, com a mesma tendência de movimento; uma tectônica superposta transversal à primeira, caracterizada por uma depressão meridional entre São João Del Rei (MG), a norte, e Santa Rita de Jacutinga (RJ), a sul.

Cordani et al. (1973) caracterizaram, com base em dados geocronológicos pelos métodos $\mathrm{K} / \mathrm{Ar}, \mathrm{Rb} / \mathrm{Sr}$ e U/Pb, a existência de três ciclos orogênicos para a região do Rio de Janeiro, com os registros sendo encontrados em rochas granitóides da Serra dos Órgãos (ciclo Brasiliano, a $620 \mathrm{Ma}$ ), nos gnaisses granulíticos do Grupo Paraíba do Sul (ciclo Transamazônico, a $2070 \mathrm{Ma}$ ) e nos gnaisses Mantiqueira, com $2800 \mathrm{Ma}$.

Brandalise et al. (1976) propuseram o termo "Associação Paraíba do Sul" para agrupar os litotipos das "Série Paraiba Desengano" de Rosier (1965) e "Série Juiz de Fora" de Ebert (1955).

Fonseca et al. (1979) reuniram as rochas gnáissicas, migmatíticas e granulíticas que se estendem na região costeira entre os estados do Espírito Santo e São Paulo sob a denominação de "Faixa Costeira".

Oliveira (1980) elaborou uma caracterização metamórfica regional sobre as rochas granulíticas e charnockíticas encontradas na região limítrofe entre Minas Gerais e Rio de Janeiro, valendo-se para isto de dados mineralógicos, químicos, petrográficos e geocronológicos. Descreveu também na região migmatitos bandados e dobrados, com freqüentes paleossomas, restos de enclaves anfibolíticos, rochas gabróicas e metaultrabasitos. Estes migmatitos são associados à rochas básicas, ultrabásicas, graníticas, 
gnaisses biotíticos e sieníticos, granulitos e, mais raramente, a gnaisses com sillimanita $e$ granada, biotita-moscovita e quartzitos impuros (feldspáticos e ferruginosos)

Posteriormente, Machado Filho et al. (1983) englobaram as rochas aflorantes no Vale do Rio Paraíba do Sul no "Complexo Paraíba do Sul", caracterizando-as como um conjunto de gnaisses e migmatitos, fortemente bandados e cataclásticos, incluindo também rochas charnockíticas, kinzigíticas, anfibolitos, metabasitos e mármores.

Machado (1983) dividiu a região do vale do Paraíba do Sul em três domínios tectônicos: (i) dominio com vergência para NW (região entre Rio das Flores e Rio Preto); (ii) domínio central sem polaridade definida, entre as cidades de Conservatória e Barra do Piraí, ou entre Valença e Vassouras e, (iii) domínio com vergência para SE, entre as cidades de Mendes e Japeri, no limite da Serra do Mar com a Baixada Sul-Fluminense.

Machado (1984) discutiu a evolução metamórfica-estrutural entre as regiões de Vassouras e Paracambi e reconheceu seis sequências litoestruturais, que foram relacionadas às Séries Juiz de Fora e Paraíba do Sul de Ebert (1956) e à Série Serra dos Órgãos de Rosier (1965). O autor caracterizou duas fases de metamorfismo regional em fácies anfibolito alto a granulito, ambas de pressão média, com registro ainda de uma terceira fase de metamorfismo dinâmico. Definiu também quatro fases de dobramentos, onde as duas primeiras apresentavam dobras cerradas e isoclinais e as duas últimas com dobras suaves a fechadas.

Coube a Machado \& Oliveira (1986) os primeiros estudos pormenorizados de caracterização metamórfica da Faixa Paraíba do Sul, na porção Ocidental do estado do Rio de Janeiro. Os autores, ao estudarem a evolução textural e metamórfica das rochas de médio e alto graus metamórficos da região de Vassouras e Valença, concluem pela ocorrência de eventos de metamorfismo e deformação superpostos, que são responsáveis pela geração de paragêneses minerais mais antigas, registradas nos porfiroclastos de plagioclásio, e paragêneses mais novas, que constituem principalmente uma matriz granoblástica. Descrevem ainda um terceiro evento metamórfico mais fraco do que os anteriores, responsável pela formação de microclínio intersticial de terceira geração.

O Grupo Paraiba do Sul é dividido em duas grandes unidades: uma inferior com ortognaisses de composição tonalítica a granodiorítica, e outra superior com rochas supracrustais. Propõem para o Complexo Paraíba do Sul a existência de grandes zonas de cisalhamento sub verticais com forte estruturação tectônica NE-SW, que muitas vezes 
mascaram as estruturas anteriores, e colocam lado a lado rochas do embasamento e da cobertura.

Almeida et al. (1989) subdividem as rochas da porção sudoeste do estado do Rio de Janeiro, na região de Bananal, oeste da área estudada neste trabalho, em quatro unidades de mapeamento, sendo três delas metassedimentares e uma constituída por rochas graníticos.

Heilbron (1989) e Almeida et al. (1991) caracterizam o metamorfismo das rochas do Complexo Paraíba do Sul com paragêneses predominando sillimanita + biotita + granada + feldspato potássico, típicas de grau metamórfico elevado na fácies anfibolito superior. A ausência de mica branca primária e a presença de veios leucossomáticos de origem anatética, paralelos à foliação principal, são considerados indicativos da fácies anfibolito superior para o metamorfismo principal deste complexo (Heilbron et al. 1991).

Heilbron (1990) estudando a faixa Bom Jardim de Minas (MG) - Barra do Pirai (RJ), individualizou três domínios tectônicos imbricados de SE para NW, limitados entre si por falhas de empurrão: Domínio Paraíba do Sul, unidade estruturalmente superior, composta por um conjunto de rochas supracrustais e granitóides associados; Domínio Juiz de Fora, de idade Transamazônica, contendo intercalações tectônicas de rochas granulíticas ortoderivadas (Complexo Juiz de Fora), e de supracrustais do Grupo Andrelândia; Domínio Andrelândia, englobando a unidade basal do Grupo Andrelândia e seu embasamento ortoderivado (Complexo Piedade). A idade de sedimentação do Complexo Paraíba do Sul é situada entre $2.0-1.9$ e $1.4-0.9$ Ga., correspondendo respectivamente à idade do metamorfismo principal associado às fases $\mathrm{Dn}$ e $\mathrm{Dn}+1$.

Almeida et al. (1993) definem nas imediações de Barra Mansa e Volta Redonda o predominio de rochas orto e paraderivadas, em condições metamórficas de alto grau. Os autores, com base em mapeamento geológico e análises petrográficas, Individualizam três formações: Três Barras, São João e Beleza.

As rochas Complexo Paraíba do Sul são caracterizadas com metamorfismo inicial de pressão intermediária a alta, seguido por metamorfismo de pressão mais baixa com acréscimo de temperatura, sendo então acompanhadas por abundante magmatismo (tipo-1 e tipo-S), indicativos de fases tardi e pós-colisionais (Trouw 1992, Heilbron 1993, Fernandes et.al. 1995, Porcher 1997). 
Nummer et al. 1994 subdividem as rochas da região de Pinheiral nos seguintes litotipos: biotita gnaisse, hornblenda gnaisse, biotita-moscovita gnaisse, microclina gnaisse porfiroclástico e rochas ígneas associadas (ácidas e básicas), que são muito semelhantes as rochas orto e paraderivadas descritas por Almeida et al. 1993.

Machado \& Endo (1994) discutem para a região a existência de zonas de cisalhamento sinistrais mais jovens do que às zonas de cisalhamento destrais. Estas zonas reativariam zonas de cisalhamento mais antigas, porém num e quadro cinemático diferente.

Recentemente, estudos de petrotrama em plagioclásio de rochas miloníticas da ZCAP tem confirmado a existência de regime tectônico transpressivo, bem como tem sugerido o predomínio do mecanismo de deformação por cisalhamento puro sobre o mecanismo de cisalhamento simples (Egydio-Silva \& Mainprice 1999).

\subsubsection{A estrutura divergente do Vale do Rio Paraiba do Sul}

No final do século passado, uma importante estrutura sinformal chamou a atenção de Derby (1880) na região do vale do Rio Paraíba do Sul, porção ocidental do estado do Rio de Janeiro, entre as Serras e Mantiqueira (MG/RJ) e do Mar (RJ), com os gnaisses apresentando mergulhos predominantes para SE e NW, respectivamente.

Coube a Washburne 1930 as primeiras referências sobre os grandes falhas na região do vale do Rio Paraíba do Sul, denominando-as falhas do Paraíba, Paraitinga e Paraibuna, todas de caráter normal.

No mesmo ano, Moraes Rego (1930), realizando trabalhos geomorfológico no estado de São Paulo e, posteriormente, Lamego $(1936,1946)$ no Rio de Janeiro, descreveram a estrutura divergente do vale do Rio Paraíba do Sul, referindo-se como um "imenso sinclinório".

Ebert (1968) reafirma a presença de uma estrutura regional em forma de leque, observada entre o sul de Minas Gerais e o noroeste do estado do Rio de Janeiro, caracterizada pela mudança de vergência da estrutura regional.

Braun (1972 e 1975) caracterizou pela primeira vez a presença de megazonas de cisalhamento regionais e considerou a associação de sinformas e antiformas com megafalhas rúpteis e zonas de falhas transcorrentes profundas. 
Campanha (1980 e 1981), com base em estudos realizados na região de Três Rios, caracteriza o Lineamento de Além-Paraíba num contexto evolutivo (estrutural e metamórfico) de rochas blastomiloníticas com sucessivas fases de movimentação e recristalização. Considera que a fase principal de metamorfismo e deformação ocorreu no ciclo Brasiliano, ao redor de $620 \mathrm{Ma}$.

Sadowski (1980) expandiu o conceito de cinturão de cisalhamento de Ramsay e Graham (1970) e aplicou para as zonas de cisalhamento do Sudeste do Brasil, englobando nelas a de Além-Paraiba. Posteriormente, em 1983, analisa os grandes falhamentos do sudeste brasileiro, como de Cubatão e Além-Paraíba, associando estas falhas transcorrentes a grandes empurrões, de forma análoga ao que ocorrem nas falhas do Moine e Great Glen, e na Frente Grenville, no Canadá.

Machado (1983 e 1984) discute a estruturação tectônica regional e utiliza o termo "estrutura divergente" para se referir a geometria sinformal da estrutura do vale do Rio Paraíba do Sul. Reconhece três fases de dobramentos e identifica duas zonas principais de cisalhamento, uma de alto ângulo e outra de moderado mergulho. Salienta que o Complexo Litoral Fluminense atuou como antepaís para os dobramentos que afetaram o Grupo Paraiba, com suas rochas mostrando invariavelmente vergência para SE.

Dayan \& Keller (1989), com base em estudos realizados na região de Três Rios, caracterizam a presença de um forte estiramento vertical nas rochas associadas ao Lineamento de Além-Paraíba, relacionando a deformação a um regime transpressivo (Correa Neto 1995, Correa Neto \& Dayan 1993).

Heilbron et al. (1991), propuseram a denominação de megassinforma do Paraiba do Sul e relacionaram sua geração a fase regional D3, conforme efetuado antes por Machado (1983). Posteriormente, em 1993, reafirmam esta posição, justificando com base na repetição de unidades litológicas (Paraiba do Sul, Andrelândia e Juiz de Fora) nas abas norte e sul, respectivamente, da citada estrutura.

Machado \& Endo (1993) descrevem a existência de uma estrutura-em-flor positiva regional na porção central do Cinturão Ribeira no Rio de Janeiro, que corresponde a mesma estrutura descrita localmente na região de Três Rios por Correa Neto \& Dayan (1993). Neste trabalho, os autores explicam a presença dos granulitos na parte central da zona de cisalhamento de Além-Paraíba como o resultado do alçamento tectônico produzido durante o regime transpressivo. 
Siva (1995) considera o Lineamento de Além-Paraíba como uma grande zona de cisalhamento dúctil de deformação heterogênea, com rochas miloníticas associadas, caracterizada por uma movimentação cinemática destral.

\subsubsection{Modelos Tectónicos}

\section{$\checkmark$ Cinturäo Paraiba do Sul (CPS) e granitos Neoproterozóicos}

Machado (1984) propôs um modelo tectônico de colisão de placas continentais para a formação da Faixa Paraíba do Sul, com a polaridade tectônica sendo explicada pela existência de placas litosféricas situadas a NW e SE, respectivamente. Após a colisão dessas duas massas continentais, teria ocorrido cavalgamento da Faixa Paraiba do Sul. Num estágio posterior, com uma geometria obliqua, teria evoluido para a formação de zonas de cisalhamento de alto ângulo com falhas transcorrentes e oblíquas associadas.

Os trabalhos de Heilbron et al. (1991, 1993, 1994 e 1995) consideram a evolução tectônica do segmento central da Faixa Ribeira de idade brasiliana, incluindo a formação da megassinforma do Paraíba do Sul (Heilbron 1990), relacionada a um modelo tectônico de dois estágios: o primeiro de convergência frontal e o segundo com convergência obliqua. No primeiro estágio, as deformações seriam contínuas, fases D1 + D2, e metamorfismo M1 contemporâneo, com formação de dobras recumbentes em bainha, estruturas duplexes e escamas tectônicas superpostas para NW; no segundo estágio, são reativados os empurrões, com verticalização das estruturas preexistentes, implantação de transcorrências discretas e geração da megassinforma do Rio Paraíba do Sul, ambas relacionadas a fase D3 (Machado 1983 e 1984, Heilbron et al. 1991). Esta fase teria sido acompanhada de um segundo metamorfismo (M2), com idade entre 535 e $520 \mathrm{Ma}$. (Machado N. et al. 1996). Segue-se a fase D4, caracterizada pela mudança da direção do plano axial de dobras ortogonais à faixa e pela ocorrência de estruturas eminentemente rígidas de nivel crustal raso.

Heilbron et al. (1998a, 2000) dividem o Setor Central da Faixa Ribeira em domínios tectônicos ou terrenos Oriental e Ocidental, limitados por importante zona de cisalhamento de baixo ângulo para NW - Limite Tectônico Central (Almeida et al. 1998), baseados na elevada proporção de embasamento de idade pré- 1,8 Ga., ocorrência do Complexo Rio Negro (Tupinambá et al. 1996) e granitóides pré-colisionais (Tupinambá et al. 1998a) no 
setor Oriental. Na parte central do Domínio Paraiba do Sul caracterizam a existência de uma klippe, já anteriormente referida por Trouw (1995).

Vauchez et al. (1989, 1992 e 1994) consideram a existência de tectônica tangencial inicial para a Faixa Ribeira, que teria evoluido para uma tectônica de escape lateral paralela ao orógeno.

Machado \& Endo (1993) redefinem o Cinturão Ribeira como "Cinturão de Cisalhamento Atlântico", justificando a denominação com base no arcabouço tectônico, na prioridade e abrangência envolvida pelo nome. Definem a existência de uma megaestrutura em-flor positiva regional associada com zonas de cisalhamento dúcteis de alto ângulo, formadas conjuntamente por colisão obliqua em regime transpressional. Este modelo difere dos demais modelos, que envolvem também colisão oblíqua, por considerar a tectônica tangencial como contemporânea à tectônica transcorrente.

Inúmeros autores têm descrito esta mesma tectônica transcorrente, porém considerando-a como posterior à tectônica tangencial.

Ebert et al. (1993 e 1995) propõem um modelo colisional leste-oeste para a Faixa Ribeira, envolvendo o Cráton do São Francisco, com este comportando-se como um bloco rígido e gerando, em regime transpressional, transcorrências oblíquas na sua porção central, em contraste com as características tectônicas das Faixas Alto Rio Grande, Grupos São João Del Rei e Andrelândia.

Estes autores relacionam essa colisão a uma possivel inversão tectônica de uma antiga junção tríplice entre os Blocos Vitória, Brasília e São Paulo. O modelo é fundamentado na forma original em. cunha do Bloco São Paulo, responsável pela obliqüidade na colisão, e que possibilitou à geração de estruturas-em-flor positivas ao longo da faixa Paraíba do Sul.

\subsubsection{Modelos para o magmatismo Neoproterozóico}

Machado et al. (1989 a e b) apresentam pela primeira vez uma classificação tectônica regional para os granitóides brasilianos do estado do Rio de Janeiro e dividem em três grupos principais: pré- a sin-F1, sin-F2, sin- a pós-F3. Posteriormente, refinam esta classificação, distinguindo os grupos sin-F2, sin-F3 e sin-F4, e propõem uma divisão tectônica em granitos pré-, sin-, tardi- e pós-colisionais (Machado \& Demange 1994a e 
1998, Machado 1977). Os granitos sin-F2 (pré-colisionais) são caracterizados como representantes de um magmatismo expandido (tonalito/granodiorito/granito), do tipo-1 Cordilherano, enquanto os demais (sin-F3 e sin-F4, tardi e pós-colisionais) são considerados como produtos de um magmatismo não expandido, do tipo-I Caledoniano (Fig.2.1),

Demange et al. (1991) com base em dados geoquímicos dos granitóides dos Cinturões Ribeira no Rio de Janeiro, e Dom Feliciano no Rio Grande do Sul, caracterizam a existência de um zonamento magmático transversal aos dois cinturões, explicando esta feição pela presença de uma zona de subducção mergulhando para NW.

No aspecto tectônico regional, Machado \& Endo (1993) consideram as zonas de cisalhamento de alto ângulo como responsáveis pelo controle na colocação do magmatismo granítico de idade brasiliana associado ao Cinturão de Cisalhamento Atlântico.

Figueiredo \& Campos Neto (1993) e Wiedemann (1993) caracterizam para o segmento central do cinturão Ribeira, nas regiões do Espírito Santo e Rio de Janeiro, a existência de um arco magmático brasiliano - denominado Arco Magmático Rio Doce pelos primeiros autores - cujo desenvolvimento teria ocorrido no intervalo de 590 a $480 \mathrm{Ma}$. (os primeiros autores) e 580 a $450 \mathrm{Ma}$. (o último autor).

Os primeiros autores propõem a divisão tectônica do magmatismo desse arco em précolisional (590 a $570 \mathrm{Ma}$.), sin-colisional (560 a $530 \mathrm{Ma}$.) e pós-colisional (520 a $480 \mathrm{Ma}$ ); enquanto o último, divide em sinorogênico ( 580 a $590 \mathrm{Ma}$.), tardi a pós-orogênico (450 a 520 $\mathrm{Ma}$.), propondo ainda uma divisão do magmatismo em três séries magmáticas: uma toleíitica, outra cálcio-alcalinas médio a alto-K e a terceira álcali-cálcico-alcalina / álcali cálcica alto - $\mathrm{K}$ (mistura de magmas).

Machado \& Demange (1994a) consideraram o Batólito Serra dos Órgãos como uma entidade plutônica na evolução de arco magmático tipo-l Cordilherano, de idade brasiliana, com característica mais toleítica ou transicional (sub toleítica) do que cálcio-alcalina propriamente dita, desenvolvido numa margem continental ativa, em conseqüência de uma subducção da litosfera oceânica.

Heilbron (1995) considerou a abundância da granitogênese do estado do Rio de Janeiro como relacionada a um progressivo espessamento crustal para SE, com o magmatismo pós-tectônico de idade Brasiliana sendo relacionado a um regime extensional 
ou de relaxamento. Os granitóides são atribuídos a um contexto de evolução ensiálica e associados a colisão obliqua entre o Cráton de São Francisco e outro bloco cratônico situado a leste, resultando um empilhamento tectônico de SE para NW, através de processos de subducção A e delaminação (Heilbron 1995).

Machado \& Demange (1998) caracterizam os batólitos foliados neoproterozóicos do estado do Rio de Janeiro como granitóides do tipo-1 Cordilheranos, cálcio-alcalinos, de natureza pré-colisional, que apresentam um zonamento geoquímico transversal ao cinturão, com batólitos mais evoluídos situados na porção noroeste do mesmo e os menos evoluídos, na porção sudeste.

Este zonamento geoquímico é explicado pela presença de uma zona de subducção mergulhando para NW, ou pela migração lateral de zonas de cisalhamento em regime transpressivo. Neste mesmo trabalho os autores definem o Arco Magmático Rio Paraíba do Sul, cujo desenvolvimento teria ocorrido no intervalo de 650 a $600 \mathrm{Ma}$

\subsection{Compatimentação Tectônica do Rio de Janeiro}

No presente trabalho optou-se pela utilização de Sistema de Cisalhamento Paraíba do Sul - SCPS, o qual no Rio de Janeiro é dividido em quatro domínios estruturais maiores, dispostos, de NW para SE, na seguinte ordem: (1) Domínio Juiz de Fora, (2) Domínio Paraíba (Norte e Sul), (3) Domínio Serra dos Órgãos e, (4) Domínio Litorâneo (Norte e Sul) (Fig.2.1).

O Dominio Juiz de Fora é formado por rochas metamórficas de alto grau, com amplo desenvolvimento de fácies granulito. Nele, distinguem-se três unidades: uma plutônica com rochas charnockíticas (Unidade Comendador Venâncio) e duas outras essencialmente metassedimentares, uma de gnaisses quartzo-feldspáticos (Unidade Itaperuna) e outra de gnaisses granatíferos (Unidade Raposo), incluindo ainda gnaisses miloníticos e blastomiloníticos (Barbosa \& Sad 1983a, 1983b e 1983c).

O Dominio Paraíba é subdividido por uma zona de cisalhamento em: Domínio Paraíba Norte (fácies anfibolito, a SW, e granulito, a NE) e Domínio Paraíba Sul. Naquele, afloram extensivamente rochas do embasamento - Unidades Quirino (Machado 1984) e São João do Paraiso (Gomes \& Batista 1978), e neste predominam rochas metassedimentares, 
englobadas regionalmente na Unidade Itaocara (Castro et al. 1984a e 1984b; Sad \& Barbosa 1988).

No Domínio Serra dos Órgãos, em fácies anfibolito inferior, ocorrem ortognaisses tonalíticos a granodioriticos muito homogêneos que têm sido incluídos nas Unidades Bingen e Santo Aleixo (Penha et al. 1979), Rio Negro (Matos et al. 1980) e Japeri (Machado 1984), reunidos informalmente numa unidade de Gnaisses Granitóides (Machado \& Peloggia 1987). Porções da unidade Rio Negro foram recentemente definidas como representantes de um arco magmático pré-colisional, de natureza cálcio-alcalina, com idade U/Pb em zircões de $634 \mathrm{Ma}$. (Tupinambá 1999).

No Domínio Litorâneo reconhecem-se dois subdomínios: um, a Norte, situado em fácies anfibolito inferior/granulito, e outro a Sul, em grau metamórfico mais baixo, mas ainda em fácies anfibolito, onde as rochas supracrustais mostram decréscimo metamórfico de NW para SE (Machado \& Demange 1990).

\subsection{Rochas Granitóides Neoproterozóicas do Estado do Rio de Janeiro}

\subsubsection{Histórico}

O primeiro trabalho de integração e síntese regional sobre os granitos do estado do Rio de Janeiro foi realizado por Machado \& Pellogia (1987), onde os autores sintetizam as principais informações, e colocam o primeiro ordenamento evolutivo a partir das diferentes características petrológicas e estruturais então disponiveis sobre os granitos do estado.

Recentemente, Machado (1997), Machado \& Demange (1994 e 1998) propõem um ordenamento estratigráfico/estrutural e tectônico para os granitóides neoproterozóicos do Rio de Janeiro, incluindo modelagem geotectônica, com base em dados petrográficos, geoquímicos, geocronológicos, estruturais e tectônicos.

Os trabalhos de cunho regional são relativamente escassos e restringem-se aos trabalhos de Machado Filho et al. (1983), Machado \& Peloggia (1987), Machado et al. (1989); Machado (1997) e Machado \& Demange (1994 e 1998).

A grande parte dos trabalhos disponiveis na literatura refere-se aos maciços graníticos tardi- a pós-tectônicos (Machado 1997). Destes trabalhos, destacam-se os de Leonardos Jr. 
(1973), Pires et al. (1982), Penha et al. (1980), Penha (1984), Penha \& Wiedemann (1984), Junho (1982, 1991 e 1993), Junho \& Penha (1985), Junho et al. (1987), Caddah et al. (1987) e Porto Jr. et al. (1992), realizados sobre os granitos dos arredores da cidade do Rio de Janeiro e da região de Petrópolis e Terezópolis.

Puget \& Penha (1980) e Zorita \& Penha (1980) estudaram granitos das regiões de Magé (granitos Suruí e Andorinha); Machado Filho et al. (1983), Sad \& Barbosa (1985), Machado (1990) e Machado \& Demange (1992), Porto Jr. (1996), Tupinambá (1999), estudaram do batólito Serra dos Órgãos; Hippert (1990), o Maciço Niterói; Batista (1984), Rêgo (1989) e Rêgo \& Figueiredo (1991 e 1994), os maciços Bela Joana e Angelim. Os trabalhos de Machado (1997) e Machado \& Demange (1998) discutem conjuntamente estes maciços, em seus diferentes aspectos.

Correlações regionais entre granitos tardi- a pós-tectônicos nos Estados do Espírito Santo (Santa Angélica, Castelo, Venda Nova, Conceição de Muqui, Mimoso do Sul e Alfredo Chaves) e Rio de Janeiro (Pedra Branca, Nova Friburgo e Frades) foram realizados por Wiedemann et al. (1986a e 1987), Wiedemann (1993), Bayer et al. (1986) e Horn \& Weber Diefenbach (1987).

As informações geocronológicas existentes sobre os maciços graníticos do Rio de Janeiro apontam sistematicamente idades brasilianas. Os principais dados estão contidos nos trabalhos de Cordani et al. (1968 e 1973), Delhal et al. (1969), Bigazzi et al. (1971), Cordani \& Teixeira (1979), Siga Jr et al. (1982), Fonseca (1979), Fonseca et al. (1984), Batista (1984), Batista \& Kawashita (1985) e Menezes et al. (1987), Machado R. et al. (1996), Machado N. et al. (1996), Machado (1997), Valladares (1996) e Tupinambá (1999).

\subsubsection{Fases de deformações regionais}

A história deformacional na porção oeste do Estado do Rio de Janeiro tem sido dividida em quatro fases tectônicas principais, denominadas da mais antiga para a mais nova de F1 e F2, F3 e F4 (Machado 1984, Machado \& Demange 1994a). Estas fases são registradas nos três domínios estruturais caracterizados na região de Arrozal, e apresentam as seguintes características:

A fase F1, observada principalmente nos Domínios Quirino e Serra das Araras, corresponde a fase de deformação responsável pela formação do bandamento 
composicional, tendo sido acompanhada por metamorfismo regional de grau alto e por processos incipientes de migmatização.

A fase F2 corresponde a fase de deformação principal responsável pela geração da foliação regional - sin-metamórfica e sin-migmática - e pela intensa transposição das estruturas anteriores. Esta foliação é plano axial a dobras de perfis cerrados a isoclinais, com espessamento apical e adelgaçamento dos flancos. A esta fase associam-se regionalmente zonas de cisalhamento dúcteis de médio e alto ângulo, que imprimem um forte caráter milonítico às litologias.

A fase F3 afeta a foliação regional, sendo responsável pela geração de dobras em diferentes escalas, em geral com perfis abertos a fechados, sendo comuns eixos sub horizontalizados. Esta fase foi responsável pela estruturação de dobras regionais visualizadas nas regiões de Morretes, Passa Três, Rio Claro, norte da Zona de Cisalhamento de Arrozal, bem como pela reativação de zonas de cisalhamento de alto ângulo pré existentes (F2).

A fase F4, de direção paralela à orientação geral NW - SE, mostra-se descontínua e foi responsável pelo desenvolvimento de estruturas em condições mais rígida. A ela associamse também dobras suaves a abertas e zonas de cisalhamento rúpteis e rúpteis/dúcteis, menos expressivas do que as anteriores.

\subsubsection{Classificação Tectônica dos granitos no Dominio Paraiba do Sul}

Machado \& Demange (1991) elaboram uma divisão tectônica dos granitos do Domínio Paraíba do Sul e englobam os maciços da região de Arrozal no grupo dos granitos sin-F3. Caracterizam como corpos foliados, alongados, na forma de stocks ou de pequenos batólitos, de composição granítica a granodiorítica, relacionados às zonas de cisalhamento dúcteis de alto ângulo do vale do Rio Paraíba do Sul.

São descritos também maciços mais antigos, referidos como sin-F2, e um grupo de maciços mais novos, designados tardi-F3 a sin-F4. Os primeiros são descritos como grandes batólitos lineares, colocados em nível crustal profundo (fácies anfibolito a granulito), sendo distinguidos maciços tipo-l Cordilherano, com ou sem associação charnockítica, e maciços tipo hercínico. Os últimos são descritos como maciços isotrópicos, não foliados 
internamente, de colocação mais rasa do que os anteriores, representando um magmatismo tipo-I desenvolvido em ambiente extensional (Machado \& Demange op.cit).

Machado \& Demange (1994), levando em consideração às fases tectônicas regionais, os domínios estruturais de ocorrência, nivel estrutural de colocação, tipo composicional, caráter tectônico e dados geocronológicos disponíveis, fazem uma nova síntese sobre as rochas granitóides neoproterozóicas do estado do Rio de Janeiro, subdividindo-as em três grupos principais de granitóides: os sin-F2, sin-F3 e sin - F4.

Machado (1997) sintetiza e classifica os diferentes corpos graníticos neoproterozóicos do Rio de Janeiro, a partir de dados geoquímicos e composicionais e compara com às classificações de granitos existentes na literatura (Chapell \& White 1974, 1984 e 1992; Chapell et al. 1988; Chapell \& Stephens 1988; Pitcher 1979,1982 e 1987). Com base neste trabalho, a Suíte Intrusiva Arrozal é relacionada ao magmatismo tipo-l Caledoniano, de composição não expandida, constituída principalmente por sieno a monzogranitos e granodioritos subordinados, com associação de granitos peraluminosos.

\subsection{Compartimentação Estrutural na regiăo de Arrozal}

A região de Arrozal foi subdividida, com base em critérios estruturais, em três domínios litoestruturais: Domínio Quirino - DQ (porção NW da área), Domínio Arrozal - DA (porção Central) e Domínio Serra das Araras- DSA (porção SE da área) (Fig.1a - CAP.1).

Os três domínios são separados por importantes zonas de cisalhamento, as quais influenciaram grandemente o padrão estrutural interno dos três domínios, sobretudo nas bordas do granito Arrozal, situado no domínio Central.

\subsubsection{Domínio Quirino (DQ)}

No Domínio Quirino afioram ortognaisses de composição granodiorítica, com granítica e tonalítica subordinadas. Este domínio é caracterizado estruturalmente por amplos antiformes e sinformes, alongados, formando muitas vezes estruturas tipo pods no interior das zonas de cisalhamento, preservando sempre uma foliação mais antiga ( $\mathrm{Sn}-1$ ).

No Projeto Carta Geológica do Estado do Rio de Janeiro, desenvolvido durante as décadas de 70 e 80 , estas rochas foram denominadas de migmatitos homogêneos e 
heterogêneos ou, ainda, de diatexitos e metatexitos (vide, p.ex., Penha et al. 1979 e 1980; Ferrari et al. 1982). Tais rochas têm sido confundidas, freqüentemente, com os maciços graníticos mais antigos sin- F2 regional.

Segundo Machado (1997), embora estas rochas exibam uma invariável estrutura gnáissica, ainda é possivel reconhecer o protolito original, mesmo em locais onde a migmatização sin-tectônica foi mais intensa. Nas regiões menos afetadas por esta migmatização, a composição é em geral tonalítica a granodiorítica, sendo comum a presença de enclaves microgranulares dioríticos a quartzo dioríticos.

Foram individualizadas neste domínio as seguintes unidades de mapeamento: (i) ortognaisses, (ii) biotita gnaisse associado com hornblenda-biotita gnaisse e, (iii) granadamoscovita-biotita gnaisse, ocorrendo ainda milonitos, granodiorito-tonalito, rochas básicas/ultrabásicas e alcalinas (Nummer 1994).

\subsubsection{Ortognaisses}

Esta unidade aflora na porção norte e noroeste da área, com uma expressão areal importante.

As melhores exposições ocorrem em pedreiras entre as cidades de Passa Três e Rio Claro, e ao longo do Ribeirões Cachimbal e Vargem Alegre, ou ainda a meia-encosta de morros íngremes da porção NW da área.

Macroscopicamente, estas rochas são caracterizadas por intercalações de bandas leucocráticas de espessura milimétrica a centimétrica, constituídas por quartzo, plagioclásio e microclinio, que se intercalam com leitos mesocráticos centimétricos, contendo quartzo, biotita, plagioclásio e microclínio, com leitos melanocráticos milimétricos.

Estes leitos possuem em geral textura granular, com cristais hipidiomórficos, de granulação fina a média (2 a $3 \mathrm{~mm}$ ), podendo conter localmente megacristais de microclínio e quartzo poligonizados.

Ocorrem nesta unidade veios e bolsões pegmatóides, dispostos em geral de forma concordante com foliação regional

Na Pedreira de Vargem Alegre, é comum a presença de minerais metamórficos como sillimanita (fibrolita) e granada (almandina). As estruturas tectônicas presentes na pedreira sugerem taxa deformação elevada. As rochas ao microscópico mostram textura 
granoblástica poligonizada, de granulação média a grossa, com cristais simplectíticos finos de quartzo, ou de forma arredondada exsolvidos em feldspatos.

A composição mineralógica modal média é a seguinte: plagioclásio $33 \%$, microclínio $32 \%$, quartzo $28 \%$ e biotita $5 \%$, com esta última podendo estar alterada para clorita e sericita. Ocorrem ainda como acessórios zircão, minerais do grupo do epídoto, granada e sillimanita.

\subsubsection{Homblenda biotita gnaisse}

Os afloramentos desta unidade são observados em cortes das Rodovias Presidente Dutra ( $\mathrm{km} \mathrm{465)} \mathrm{e} \mathrm{Tancredo} \mathrm{Neves,} \mathrm{próximos} \mathrm{de} \mathrm{Volta} \mathrm{Redonda.} \mathrm{Esta} \mathrm{unidade} \mathrm{possui}$ contato gradacional com moscovita-biotita gnaisse.

Macroscopicamente, caracteriza-se por um bandamento gnáissico irregular, com espessura variável, centimétrica a decimétrica $(2$ a $20 \mathrm{~cm}$ ). A biotita é o mineral mais abundante nesta unidade. Possui granulação fina à média, sendo associada muitas vezes com hornblenda e, mais raramente, com moscovita, que ocorre em pequenas quantidades.

Ao microscópio, caracteriza-se por uma textura inequigranular, com cristais xenomórficos a idiomórficos, e granulação fina à média.

\subsubsection{Granada moscovita biotita gnaisse}

Os melhores afloramentos desta unidade podem ser observados em cortes da rodovia Presidente Dutra, entre o início da rodovia Tancredo Neves e o acesso para as cidades de Arrozal e Pinheiral. Esta unidade situa-se no prolongamento da Zona de Cisalhamento de Além-Paraíba, e ocorre próximo à região da Estação Fitossanitária de Pinheiral. Aqui observa-se o contato com a unidade de hornblenda-biotita gnaisse. Uma caracteristica desta unidade é a existência de uma expressiva quantidade de moscovita, sugerindo um intenso processo de moscovitização associado ao metamorfismo.

Os granada moscovita-biotita gnaisses ocupam uma região de relevo aplainado, e afloram no topo de colinas ou na meia-encosta, onde são comuns na forma de lajedos.

Ao microscópico é caracterizada por quartzo $31 \%$, plagioclásio $28 \%$, microclínio $21 \%$, biotita $11 \%$, moscovita $8 \%$, minerais opacos $2 \%$, apatita e zircão como acessórios, 
ocorrendo ainda minerais de alteração como epídoto 0,5\%. Ocorre também mirmequita. A textura é granoblástica, de granulação fina-média, com cristais de quartzo poligonizados, destacando-se a presença de porfiroclastos de quartzo, plagioclásio e microclínio. Ocorrem associados veios pegmatíticos entre 0,20 e $1,5 \mathrm{~m}$ de espessura, constituídos de quartzo, feldspato, moscovita e, localmente, turmalina.

\subsubsection{Dominio Arrozal}

O Domínio Arrozal é constituido pelos Maciço Graníticos Arrozal (MGA) Getulândia (MGG) e Fortaleza (MGF), os quais integram a Suite Intrusiva Arrozal (SIA), definida no presente trabalho.

As rochas miloniticas ocupam principalmente às bordas dos maciços graníticos, com desenvolvimento mais pronunciado junto às zonas de cisalhamento que limitam este domínio. Na porção sudeste do domínio, margeando o maciço, ocorrem rochas textural e estruturalmente similares, porém mais ricas em biotita e anfibólio.

\subsubsection{Domínio Serra das Araras}

Os trabalhos de mapeamento geológico em escalas 1:50.000 e 1:25:000 realizados por professores e alunos de graduação da UFRRJ, no período entre 1986 e 1994, ao longo da Serra das Araras, no trecho da Serra do Matoso, imediações do Belvedere, e na Serra de Mazomba, arredores de Itaguai, caracterizaram neste domínio as seguintes unidades de mapeamento: (i) sillimanita-granada-biotita xistos; (ii) microclínio gnaisses; (iii) granada-biotita gnaisses; (iv) migmatitos $e(v)$ granitos. Ocorrem, ainda, pequenas intrusões de corpos aplíticos e de diques básicos, lentes de rochas ultrabásicas, rochas cálcio-silicáticas e granitos tipo-S associados (Nummer 1994). 


\section{CAPITULO 3}

Granitóides da Suite Intrusiva Arrozal

O presente capítulo apresenta os dados geológico-estruturais de campo obtidos sobre as rochas que compõem a Suitte Intrusiva Arrozal e suas encaixantes, aliando à caracterização petrográfica e estrutural (análise geométrica e cinemática) de laboratório.

Introdução.

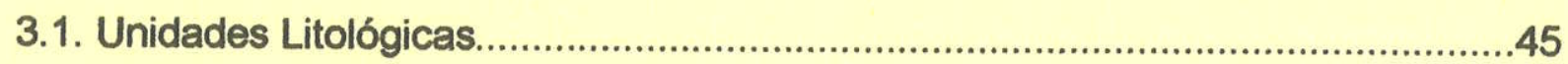

3.1.1. Maciço Granítico Arrozal (MGA) ....................................................................45

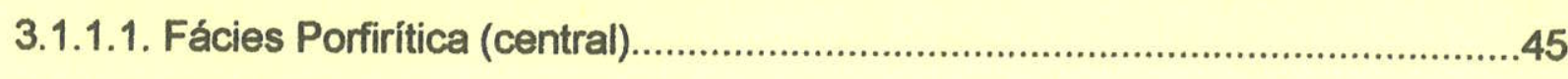

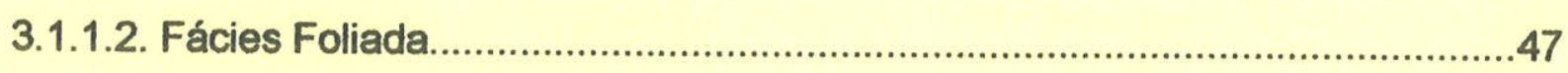

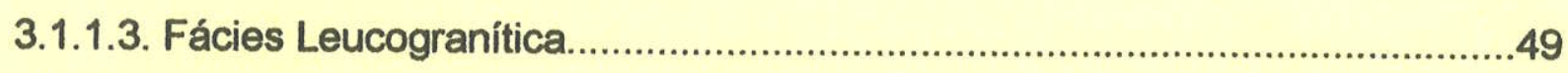

3.1.1.4. Enclaves Máficos....................................................................................49

3.1.1.5. Diques e sills de rochas básicas................................................................49

3.1.2. Maciço Granítico Getulândia (MGG)e Fortaleza (MGF).................................50

3.2. Análise Geométrica e Cinemática.................................................................51

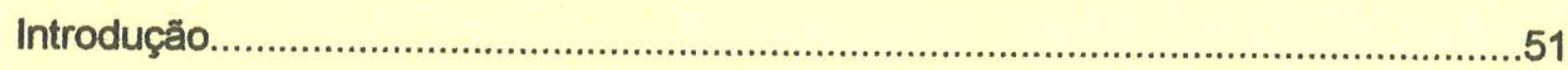

3.2.1. A Suite Intrusiva Arrozal (SIA) e as zonas de cisalhamento dúcteis................52

3.2.2. A Suite Intrusiva Arrozal e as rochas encaixantes..........................................53

3.2.3. Análise Geométrica dos Domínios................................................................55

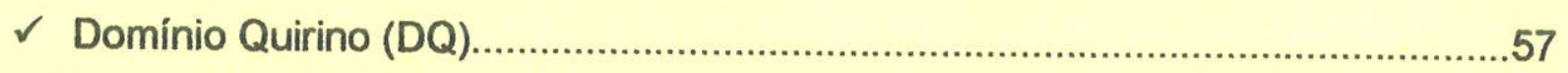

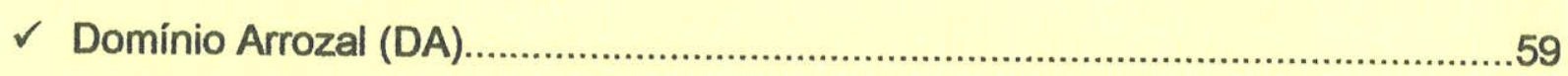

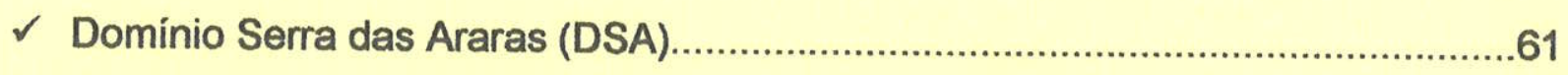

3.2.4. Marcadores cinemáticos do Domínio Arrozal..................................................62

3.2.5. Marcadores cinemáticos das rochas encaixantes (Domínios Quirino e Serra

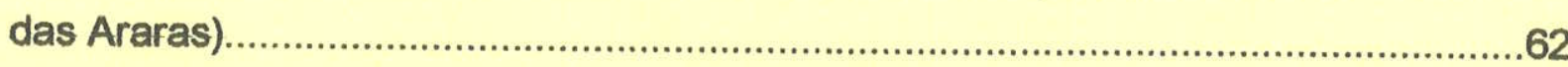

3.2.6. Padrão da Trajetória da Foliação Tectônica...................................................62

3.2.7. Padrão da Trajetória da Lineação Tectônica....................................................66

3.2.8. Relações entre deformaçăo e metamorfismo.....................................................66

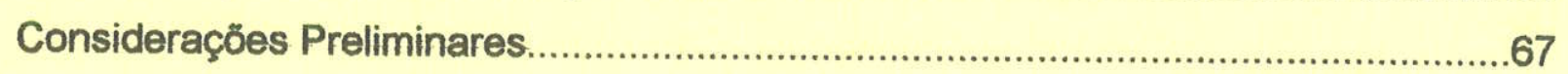




\section{Introdução}

O termo suite é aqui aplicado, segundo o Código de Nomenclatura Estratigráfica Brasileira, para designar duas ou mais associações de rochas. A identificação da Suite Intrusiva Arrozal é apoiada em argumentos geológicos, estratigráficos, mineralógicos petrográficos e geoquímicos comparáveis.

A Suite Intrusiva Arrozal, aqui definida, é constituida pelos Maciços Graníticos Fortaleza, Getulândia e Arrozal. São maciços com características petrográficas e estruturais semelhantes, que se acham alinhados em uma estreita faixa de direção NESW, limitada a NW pela Zona de Cisalhamento de Além-Paraíba (ZCAP), e a SE pela Zona de Cisalhamento de Mendes (ZCM)(Fig.3.1).

Estes maciços possuem composição dominante sieno a monzogranítica, com álcalifeldspato granítica e granodiorítica subordinadas, contendo enclaves microgranulares de dimensões variáveis entre decimétricas a quilométricas, a exemplo do que ocorre associado no Maciço Granítico Getulândia na porção norte. Corresponde a um magmatismo de composição não expandida, do tipo-I Caledoniano (Machado \& Demange 1994). Estruturalmente, são relacionados aos granitos sin-F3 descritos na literatura. São corpos controlados inteiramente pelas transcorrências regionais. 


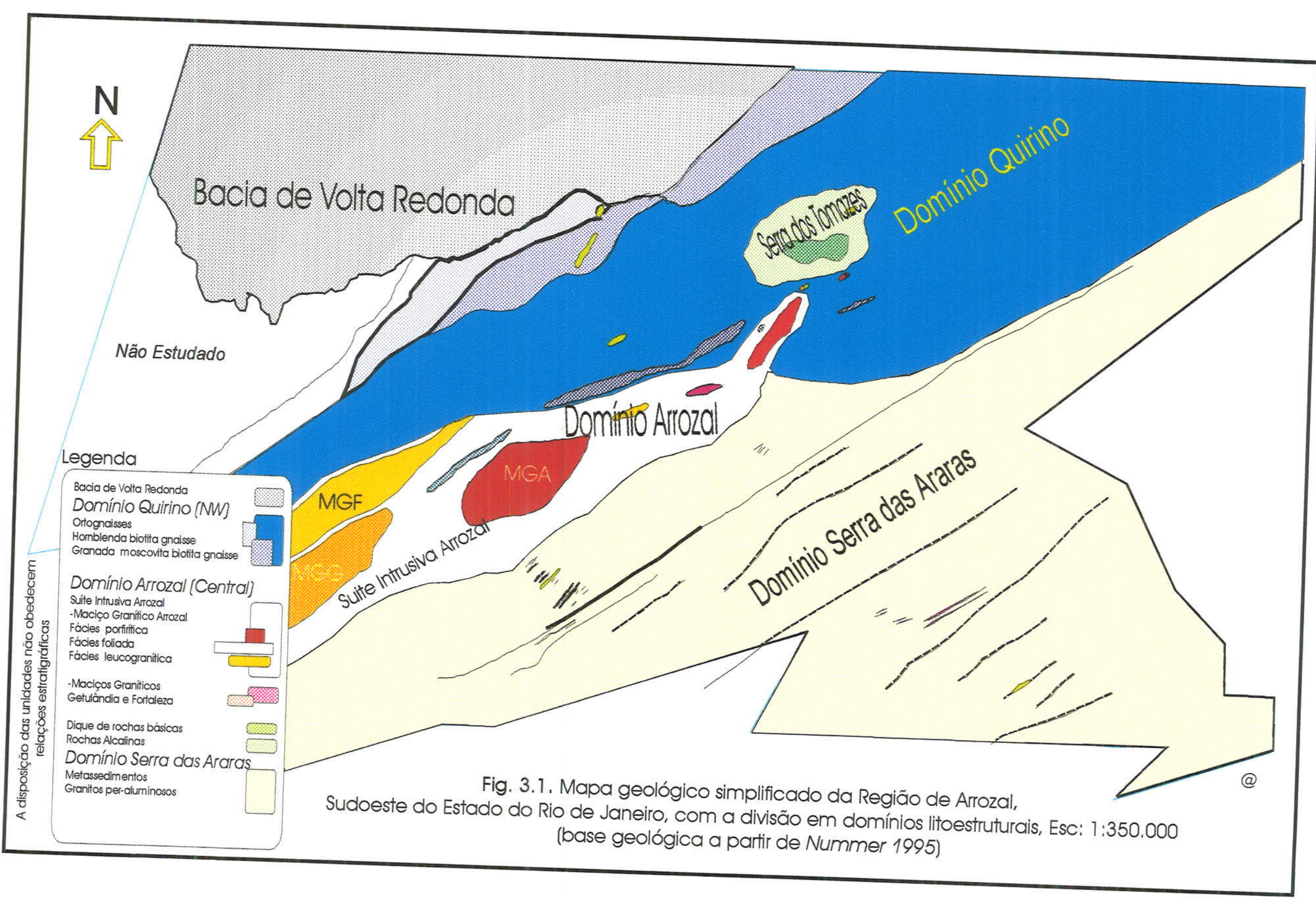




\subsection{Unidades Litológicas}

\subsubsection{Maciço Granitico Arrozal (MGA)}

Com base nas características estruturais e composicionais foi possível dividir o MGA em três faciologias principais: (i) fácies porfirítica com estruturas magmáticas preservadas; (ii) fácies foliada e, (iii) fácies leucogranítica.

Estas faciologias apresentam variações mineralógicas, seja no volume de megacristais, na quantidade de biotita ou mesmo nos aspectos texturais e estruturais das mesmas.

A biotita é o máfico comum nas quatro faciologias e pode ocorrer também associado ao anfibólio na parte norte do maciço. Ocorrem ainda: granada +- sillimanita +- moscovita, e, raramente, anfibólio / piroxênio. Os minerais acessórios são apatita, zircão, titanita, magnetita e ilmenita, com estes últimos sendo muito úteis para separar algumas faciologias graníticas da região.

\subsubsection{Fácies Porfiritica (central)}

Esta fácies perfaz cerca de $20 \%$ em área do maciço. Caracteriza-se macroscopicamente por uma granulação média a grossa $(0,5$ a $2,5 \mathrm{~mm})$, textura inequigranular a levemente porfiritica, com baixa proporção de megacristais $(<10 \%)$, em tamanho sempre inferior a $7,0 \mathrm{~mm}$. O termo porfiritico é aqui aplicado para rochas com megacristais de feldspato de tamanho entre 1 a $15 \mathrm{~cm}$.

A composição modal dominante é plagioclásio $55 \%$, microclínio $20 \%$, quartzo $15 \%$, biotita $10 \%$, acessórios $1 \%$, incluindo granada, mica branca, epidoto, zircão, apatita, carbonato, sericita e minerais opacos. A granada ocorre como agregados arredondados com diâmetro de cerca de $4 \mathrm{~cm}$., associada com cristais de mica branca, e localizada próximos a veios de quartzo.

Esta faciologia ocupa as porções central e sudeste da área estudada e, principalmente, nos arredores da Fazenda São Lourenço. Aflora em geral na semiencosta e no topo de elevações com altitude média de $600 \mathrm{~m}$. 
A fácies porfirítica caracteriza-se por uma grande homogeneidade textural e petrográfica, podendo ocorrer variações locais nas proporções de biotita, que aumenta para sul-sudeste.

Um tipo particular de rocha associado a esta faciologia ocorre próximo à Rodovia Presidente Dutra e na Fazenda São Lourenço, sendo representado por um leucogranito de composição quartzo-monzonítica (MAVR61), contendo quartzo, plagioclásio, biotita, anfibólio cálcico, apatita e allanita como acessórios, com características qeoquímicas menos evoluidas do que os granitos inequigranulares (ver CAP. 4).

Os contatos NW e SW são transicionais com a fácies foliada (item 3.1.1.2), sendo comuns junto a eles enclaves microgranulares de composição quartzo diorítica ou tonalítica.

A foliação de fluxo magmático é evidenciada na porção interna do maciço, próximo da Torre de Repetição de Arrozal, sendo aí definida pelo arranjo planar incipiente de cristais de biotita ou de feldspatos nas porções mais porfiríticas O quartzo e feldspatos da matriz exibem um arranjo granular não orientado.

Cabe salientar que, em escala macroscópica, a orientação da biotita foi o principal critério utilizado como para definir a orientação da rocha, enquanto na escala microscópica foram utilizados critérios adicionais, que permitiram avaliar melhor a natureza desta foliação. Como resultado, foi possível identificar nesta escala duas orientações principais de biotitas: uma definida por biotita bem cristalizada, com uma orientação definida e, outra, menos cristalizada, onde esta orientação é discordante da anterior; minerais como quartzo, plagioclásio e microclínio encontram-se isentos de deformação tectônica (ver CAP.4).

Os feldspatos são euédricos a subédricos, quadráticos e retangulares, desenvolvendo localmente estruturas em synneusis. O plagioclásio apresenta geminação segundo a lei da albita; o quartzo (melhor marcador da deformação incipiente) é equidimensional, sem evidências de processos de deformação ou recristalização. Estes minerais apresentam apenas evidências de uma deformação rúptil-dúctil. 


\subsubsection{Fácies Foliada}

As rochas desta fácies ocorrem na porção NW do maciço e ao longo de corredores de cisalhamento NE-SW e ENE-WSW. Ocupa regiões de relevo aplainado, formando pequenas colinas alongadas na mesma direção do cisalhamento, com os afloramentos ocorrendo em meia-encosta, em geral semi-alterados, sendo comum o desenvolvimento de vossorocas. Os methores afloramentos são encontrados no trecho entre Arrozal e São Joaquim da Grama na Fazenda São Lourenço, nos arredores cidade de Arrozal, nas Fazendas Vendinha e São Francisco, e a noroeste da Vila Roma II. Associam-se veios ou bolsões pegmatóides deformados conjuntamente por um cisalhamento simples com indicadores cinemáticos sugerindo movimentação destral.

Esta faciologia apresenta um pronunciado bandamento gnáissico caracterizado por intercalações de niveis centimétricos melanocráticos de biotita, alternados com níveis leucocráticos, com predomínio de quartzo e feldspato. Esta estrutura gnáissica é formada por mecanismo de cisalhamento simples a partir de rochas graníticas do MGA. Nos niveis biotíticos associam-se hornblenda, enquanto nos niveis leucocráticos pode ocorrer mica branca preenchendo fraturas no quartzo.

Os megacristais de feldspato alcalino são em geral pertíticos e os de plagioclásio, antipertíticos, sendo ambos deformados, em forma lenticularizada, conferindo à rocha uma estrutura tipo augen. É comum a existência de foliações " $C$ " formando alto a médio ângulo com a foliação " $\mathrm{S}$ ", ou sendo ambas paralelizadas, e neste caso com realce das feições miloníticas e/ou gnáissicas.

O quartzo mostra-se alongado, com contornos lobados, possuindo forte extinção ondulante.

A textura é muitas vezes milonítica, granulação média a grossa, com os minerais apresentando as seguintes porcentagens modais: 40 a $55 \%$ de plagioclásio, 17 a $20 \%$ de microclínio, 15 a $25 \%$ de quartzo, 10 a $14 \%$ de biotita e mica branca $(<1 \%)$; os minerais acessórios são epídoto, zircão, clorita, apatita e minerais opacos, podendo ocorrer ainda granada (almandina) e turmalina.

Os megacristais de feldspato são freqüentemente rotacionados, com indicação de movimentos horários e anti-horários e presença de geminação em cunha. 
Esta fácies associa-se, eventualmente, a rochas de granulação mais grossa, que podem ser classificada como milonito-gnaisses (sensu Higgins 1971), mostrando uma composição modal diferente, com a seguinte mineralogia: $51 \%$ de quartzo, 28\% de plagioclásio, $18 \%$ de microclínio, $3 \%$ de mica branca e $<1 \%$ de biotita.

Ao microscópio é uma rocha orientada de textura milonítica, com uma matriz fina, constituída de um agregado quartzo-feldspático, e porfiroclastos de feldspatos lenticularizados, associados com fitas de quartzo e lamelas de biotita.

Na porção sudeste do MGA, nos arredores de São Joaquim da Grama (próximo da Igreja e na Fazenda São Lourenço) e a noroeste de Arrozal, ocorre uma estreita faixa de filonitos de direção NE-SW, associada à Zona de Cisalhamento de Mendes, caracterizada por uma variação acentuada no teor em micas e aluminossilicatos, exibindo textura milonitica pronunciada.

Este filonito possui a seguinte composição modal média: 10\% de sillimanita, $30 \%$ de biotita (constituindo a matriz fina predominante), $20 \%$ de quartzo, $30 \%$ de feldspatos alterados (caulinizados) e $10 \%$ de minerais opacos.

A foliação milonítica é salientada por cristais de sillimanita (fibrolita) e biotita avermelhada dispostas como agregados orientados em lentes sigmoidais (pods de deformação), envolvidos por finas películas de óxido de ferro. Nos domínios (microlitons) entre a foliação milonítica encontra-se preservado uma foliação anterior (foliação Sn-1).

Observam-se também intercalações lenticularizadas enriquecidas em biotita e anfibólio de material, relativamente preservadas da deformação. São rochas de granulação média a grossa, constituídas por $29 \%$ de quartzo, $26 \%$ de microclínio, $23 \%$ de plagioclásio, $15 \%$ de hornblenda, $5 \%$ de biotita, ocorrendo ainda como acessórios titanita, minerais opacos, moscovita, epidoto e zircão. Estas lentes possuem textura granoblástica, com presença de intercrescimento simplectítico e mirmequítico. O registro de retrometamorfismo acha-se evidenciado pela desestabilização de anfibólio para biotita, juntamente com epidoto, moscovita e clorita. 


\subsubsection{Fácies Leucogranitica}

Esta fácies encontra-se associada à Zona de Cisalhamento de Arrozal (ZCA). Constituem corpos alongados, foliados, com presença de uma foliação de fluxo magmático, que é afetada por um foliação tectônica de alto ângulo sub paralela.

Predominam rochas de granulação média a grossa, inequigranulares e porfiriticas, leucocráticas, rosadas e esbranquiçadas, podendo conter enclaves básicos microgranulares, cuja relação eixo maior e menor é 5:1.

A composição dominante é monzogranítica (ver CAP.4) e exibe a seguinte composição modal média: $62 \%$ de plagioclásio, $25 \%$ de quartzo, $10 \%$ de ortoclásio, $2 \%$ de granada, $0,5 \%$ de biotita e $0,5 \%$ de minerais opacos. Pode conter hornblenda, titanita, granada e magnetita, zircão e epidoto como acessórios.

\subsubsection{Enclaves Máficos}

Estas rochas possuem textura granoblástica, granulação média a grossa, tendo a seguinte composição mineralógica modal média: $29 \%$ de quartzo, $26 \%$ de microclínio, $23 \%$ de plagioclásio, $15 \%$ hornblenda, $5 \%$ biotita, $1 \%$ piroxênio, contendo ainda como acessórios titanita, zircão e epidoto. São classificados como hornblenda monzogranitos.

São enclaves arredondados ou alongados (relação entre eixo maior e menor de 10:1), de granulação fina, não foliados, de dimensões decimétricas (até $60 \mathrm{~cm}$.), orientados ou não, com enriquecimento em biotita próximo ao contato com a rocha hospedeira. Localmente, estes enclaves são abundamtes, como nas imediações da Fazenda São Lourenço.

\subsubsection{Diques e sills de rochas básicas}

A sul da área estudada e na sua porção central ocorrem expressivos diques ou sills de diabásio, gabros e gabro-noritos, não deformados, com idade provável mesozóica (Nummer 1991). Na porção central, próximo às zonas de cisalhamento, tais corpos possuem espessuras variáveis desde algumas dezenas até centenas de metros, podendo atingir até $1 \mathrm{~km}$. de espessura. Ocorrem como corpos tabulares, verticalizados, alojados em zonas de cisalhamento. Estas rochas ocorrem comumente como blocos ou matacões 
alinhados na superfície do terreno. São rochas escuras, de granulação fina (borda) a média (porção central), não deformadas, constituídas de piroxênio, plagioclásio e minerais opacos. Sua alteração produz um solo argiloso de cor avermelhada (solo PDV).

Ao microscópio possuem textura granular a subofítica, granulação fina, sendo constituídas por $60 \%$ de plagioclásio, $30 \%$ piroxênio (augita) e $10 \%$ de minerais opacos.

\subsubsection{Maciços Graniticos Getulândia (MGG) e Fortaleza (MGF)}

Estes maciços graníticos, situados na extremidade SW da área estudada, alongados e com estrutura a orientada, de composição monzo a sienogranítica e álcali-feldspato granítica, constituem-se no grupo de granitos mais numerosos na região de Getulândia.

O álcali-feldspato granito aqui descrito corresponde a uma rocha que se situa entre o campo 1 e 2 do diagrama QAP de Streckeisen (1976) (Fig.4.14 - CAP.4), e caracterizase por um conteúdo elevado de feldspato alcalino e quartzo, com o plagioclásio ocorrendo como componente pertítico.

Corresponde ao granito hipersolvus de Tuttle \& Bowen (1958), que pode evoluir localmente para granitos subsolvus, na presença de dois feldspatos.

Estas rochas ocupam extensas porções a sul-sudoeste e norte-noroeste da área estudada, e são também observadas ao longo das rodovias Presidente Dutra e Tancredo Neves.

A textura é inequigranular, de granulação grossa, com o microclínio e quartzo sendo os principais minerais responsáveis pela definição de uma foliação magmática incipiente à rocha. Podem ocorrer niveis enriquecidos em biotita e anfibólio, de espessura milimétrica, que se intercalam com niveis leucocráticos centimétricos, constituídos exclusivamente de quartzo e microclínio róseo.

A análise modal desta litologia mostra o seguinte conteúdo médio de minerais: $65 \%$ de microclínio, $30 \%$ quartzo, $5 \%$ de biotita, ocorrendo ainda como acessórios zircão, apatita e moscovita (secundária). 


\subsection{Análise Geométrica cinemática}

\section{Introduçăo}

Algumas considerações iniciais visam aqui esclarecer os procedimentos adotados na análise estrutural. Neste sentido, procurou-se inicialmente separar as estruturas tectônicas (secundárias) das estruturas magmáticas (primárias), embora sabendo que em muitos casos seja uma tarefa difícil, sobretudo tratando-se de rochas granitóides posicionados em zonas de cisalhamento, onde a deformação é extremamente heterogênea e nem sempre os critérios de campo são definitivos, ficando-se muitas vezes na dependência do exame de lâminas delgadas para elucidar a questão.

Embora os critérios gerais para separação entre estruturas magmáticas e tectônicas em rochas granitóides tenham sido apresentados no CAPíTULO 1, o assunto é aqui retomado para salientar os aspectos mais importantes para separação entre estas duas estruturas. Paterson \& Fowler (1989) e Paterson et al. (1998) assinalam que a origem estritamente tectônica para as foliações em rochas granitóides somente é conclusiva quando esta foliação é definida por minerais metamórficos e apresenta continuidade com a foliação regional.

Vários autores consideram que a distinção entre foliação tectônica e magmática é fundamental para o entendimento da forma de colocação dos plutons graníticos e sua relação temporal com o metamorfismo e deformação das rochas encaixantes (Berguer \& Pitcher 1970, Castro 1987).

Além disso, são ainda importantes para estes autores o ambiente geotectônico, o regime deformacional que acompanha a colocação do corpo, bem como os indicadores cinemáticos da deformação nos estados sólido e magmático.

Foram também considerados critérios adicionais, gerais ou específicos, como àqueles discutidos em trabalhos como de Guineberteau et al. (1987), sobre o granito Mortagne, SE da França, que relacionam estruturas tipo pull-a-part associadas às zonas de cisalhamento transcorrentes como sendo os sítios propícios para o alojamento de granitos; ou ainda D' Lemos et al. (1992), que consideram a geração e transporte de granitos como relacionados a um cinturão transpressivo - o Cinturão Cadomiano do NW da França. Outros autores, como Tikoff \& Tessier (1992), consideram também o regime 
transpressivo para o alojamento do batólito Sierra Nevada da Califórnia e salientam seu controle de colocação pelos planos " $P$ " de Riedel. Petford \& Ayherton (1992) consideram que a colocação e deformação dos granitos da Cordilheira Blanca, no Peru, ocorreu ao longo de descontinuidades crustais controladas por falhas transcorrentes.

Outros autores consideram que a colocação do material magmático ocorre, essenciaimente, em ambientes distensivos associados a regimes compressivos ou extensionais (Vigneresse 1995b).

\subsubsection{A Suite Intrusiva Arrozal (SIA) e as zonas de cisalhamento dúcteis}

A Suite Intrusiva Arrozal (SIA) ocorre na porção SW do Domínio Paraíba Sul (Machado \& Demange 1994), sendo alongada segundo a zona de cisalhamento dúctil de alto ângulo que integra o Sistema de Cisalhamento Paraíba do Sul no Estado do Rio de Janeiro (Machado \& Endo 1993).

As zonas de cisalhamento dúcteis são de alto ângulo, com orientação paralela a sub paralela à estruturação regional do Lineamento Além Paraíba, sendo aqui referidas como Zona de Cisalhamento Além Paraíba (ZCAP) - destral; Zona de Cisalhamento Arrozal (ZCA - Nummer et al. 1995), e Zona de Cisalhamento Mendes (Machado 1984) ou Mendes-Itaocara (ZCMI - Fonseca et al. 1998), que balizam a área na sua parte sul. Os lineamentos tectônicos associados aos contatos geológicos pode ser observado na imagem de satélite Landsat - TM5 (Banda 3) com a inserção dos contatos geológicos (APÊNDICE 3).

Estas zonas de cisalhamento dúcteis possuem grande expressão no vale do Rio Paraíba do Sul, com largura superior a $25 \mathrm{Km}$ (Machado 1983), e representam neste setor do cinturão uma exposição de nível crustal de crosta média a média / inferior, onde sua importância se traduz não apenas na estruturação tectônica da região, mas também como elemento estrutural responsável pelo controle de grande parte dos granitóides foliados neoproterozóicos na região, sobretudo aqueles descritos na literatura como $\sin -\mathrm{F} 3$ (ou $\sin$ D3).

As feições estruturais observadas em campo na ZCA sugerem aumento progressivo da deformação para a região central da mesma e, invariavelmente, na direção NE, 
sugerindo que a deformação ao longo desta zona de cisalhamento foi heterogênea lateral e longitudinalmente.

As observações de campo sugerem ainda uma relação direta entre os maciços graníticos que compõem a SIA e estas zonas de cisalhamento dúcteis, conforme sugerem às feições texturais e estruturais (milonitos) juntos às bordas.

A trama isotrópica na porção central da SIA, grada lateralmente para uma trama orientada, onde cristais de quartzo equidimensionais, são progressivamente estirados, assumindo forma em filetes ou fitas de quartzo e agregados lenticularizados com tamanho superior a $2 \mathrm{~cm}$., juntamente com megacristais de microclínio e plagioclásio levemente estirados. Alguns destes megacristais de feldspatos possuem formas subédricas a euédricas, retangulares, em contatos angulosos, rotacionados ou não.

\subsubsection{A Suite Intrusiva Arrozal e as rochas encaixantes}

A suíte, aqui definida, é constituída por três maciços graníticos menores. Este maciços são foliados, alongados, e caracterizam um magmatismo de composição não expandida, comparável aos granitos tipo-I Caledonianos da classificação de Pitcher (1979 e 1982). São corpos sin- a cedo-F3, como Arrozal e Fortaleza, que foram colocados em nivel crustal compatível com a fácies xisto-verde alto a anfibolito.

O Maciço Granítico Getulândia, situado na continuação da área estudada, é um corpo homogêneo com características petrográficas, composicionais, geoquímicas e estruturais similares aos Maciço Granítico Arrozal, porém com alojamento aparentemente mais raso do que os demais granitos da suite.

Estes três corpos graníticos aqui interpretados como pertencentes a mesma suite petrográfica, foram alojados durante o mesmo evento deformacional $D n+2$, porém seu posicionamento ocorreu em estágios cronológicos distintos, os quais se enquadram em termos tectônicos ao magmatismo descrito na literatura como sin-F3 (Machado \& Demange 1994).

A Suite Intrusiva Arrozal caracteriza-se por rochas com composição quartzo monzonito-sienogranítica a granodiorítica (Streckeisen 1976)(Fig.4.14 - CAP.4), sendo integrada por faciologias geralmente foliadas, de granulaçäo média. Os termos não foliados possuem textura inequigranular média a levemente porfirítica. 
Outros tipos petrográficos aparecem também associados, como diorito e leucogranito, este último associado geralmente no contato do maciço próximo às zonas de cisalhamento dúcteis. O seu conteúdo em máficos é sempre inferior a $5 \%$.

A faciologia principal possui tendência porfiritica e apresenta megacristais de feldspato potássico e plagioclásio (andesina), que variam de 5 a $15 \%$ do volume total da rocha.

O contato do Maciço Granítico Arrozal com as rochas encaixantes é tectônico, sendo marcado pela presença de zonas de cisalhamento com milonitos e protomilonitos associados, cujo protólito é identificável apenas fora destas zonas. Junto aos contatos, os granitos e os gnaisses encaixantes aparecem invariavelmente paralelizados, tornando-se muito difícil a distinção entre eles. Na porção central, a foliação torna-se mais espaçada e descontínua, passando a milonitos junto às bordas do corpo. Aqui a estrutura planar paraleliza-se às estruturas das rochas encaixantes.

$\mathrm{Na}$ direção SE do maciço, próximo ao contato com as rochas encaixantes, nota-se um aumento em biotita e anfibólio, enquanto na direção NW ocorre um aumento em quartzo, feldspato e moscovita secundária. As rochas encaixantes da porção SE são constituídas de paragnaisses com a associação sillimanita e granada, enquanto nas encaixantes da parte NW predominam rochas ortoderivadas (Unidade Quirino de Machado 1984), sem o registro de uma associação mineral diagnostica do metamorfismo.

A ausência de minerais índices metamórficos nesta porção dificulta uma avaliação mais efetiva do metamorfismo e sua comparação com a parte NW. Contudo, a existência de leitos graníticos relacionados ao processo de migmatização regional em ambas as unidades é sugestivo de condições metamórficas similares e compatíveis com o grau alto de Winkler (1967). A ausência de rochas metamórficas com hiperstênio em ambas as unidades sugere que o metamorfismo não alcançou a fácies granulito. Contudo, imediatamente a norte, no domínio Juiz de Fora, ocorrem rochas com associação mineral em fácies granulito.

As amostras do MGA apresentam expressivas alterações dos feldspatos, que são saussuritizados, dos plagioclásios, epidotizados, biotitas e cloritas moscovitizadas, sugerindo assim um importante aporte de fases fluídas nestas rochas. Esta atividade 
hidrotermal parece ter sido contemporânea à implantação dos corredores de cisalhamento no maciço.

Ocorrem também veios pegmatóides constituídos por quartzo, feldspato alcalino, moscovita, turmalina e minerais opacos. Estes veios são associados com zonas de cisalhamento rúptil-dúcteis que afetam uma foliação pré existente. Tais veios são muitas vezes afetados pela atividade destas zonas de cisalhamento, imprimindo-thes uma movimentação sinistral. Notam-se deformações internas nos mesmos e recristalização oblíquas às suas paredes. As relações estruturais destes veios com as rochas graníticas sugerem um posicionamento sin- a tardi-magmáticos.

A distribuição em mapa das faciologias do maciço (Fig. 3.1) mostra que a deformação foi heterogênea nestas rochas, tendo sido mais intensa na parte norte (região de Santa Rosa), onde aparecem faixas expressivas de rochas miloníticas, e menos intensa na parte sul (região de Passa Três), onde faixas são mais restritas.

Na região de Passa Três, o MGA é constituído por rochas de composição monzogranítica a sienogranítica, de cor cinza dominante, com matriz inequigranular, caracterizando-se por proporções equivalentes de feldspato potássico, plagioclásio, quartzo e minerais máficos (biotita, predominante). Registra-se também a presença de sillimanita, granada e turmalina.

Na região de Santa Rosa, as rochas do MGA estão inseridas na ZCA, aparecendo neste local mais deformadas, incluindo texturas miloníticas freqüentes, com enclaves máficos e ultramáficos associados, juntamente com gabro-noritos, estes últimos relacionados a mesma associação descrita no Granito Getulândia (Valladares 1996).

\subsubsection{Análise Geométrica dos Dominios}

A área foi dividida em Domínios Estruturais Homogêneos (sensu Turner \& Weiss 1973), onde cada domínio possui o mesmo padrão de distribuição preferencial dos elementos. Com base neste conceito, a área foi dividida em três domínios estruturais: Domínio Quirino (domínio NW), Domínio Arrozal (domínio Central) e Domínio Serra das Araras (domínio SE )(Fig.3.2). 


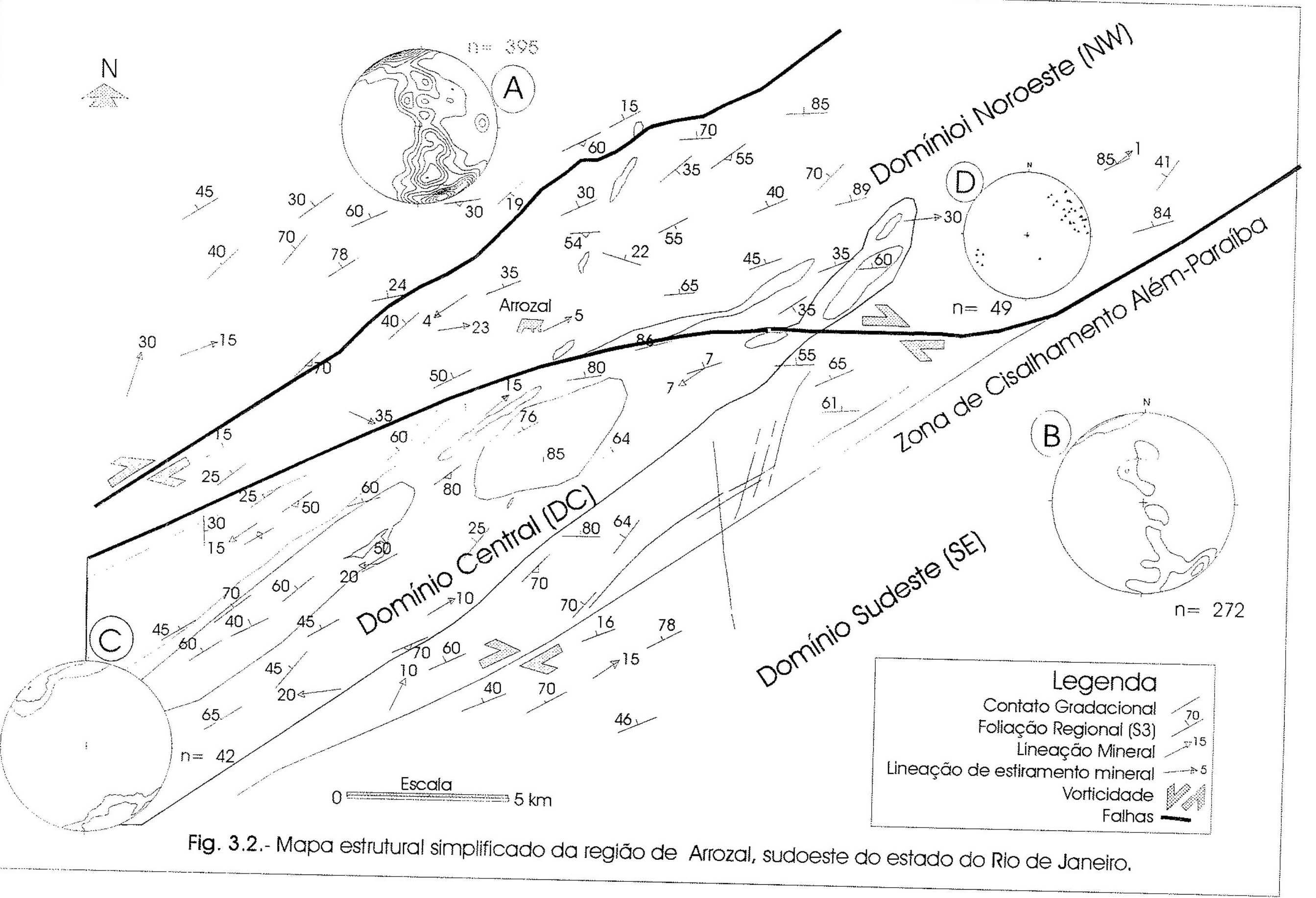


Estes domínios são limitados por zonas de cisalhamento dúcteis de alto ângulo: Zona de Cisalhamento de Além Paraiba - ZCAP (Almeida et al. 1973), entre o primeiro e o segundo domínios, e a Zona de Cisalhamento Mendes- ZCM (Machado 1984), entre o segundo e terceiro domínios. Estes domínios são também afetados por expressivas zonas de cisalhamento dúcteis de alto ângulo, com orientação sub paralela à estruturação regional às demais zonas de cisalhamento. $\mathrm{Na}$ realidade, estas zonas de cisalhamento são disseminadas nos três domínios e conferem aos mesmos uma trama milonítica dominante.

No Domínio Quirino predominam rochas ortoderivadas, regionalmente relacionadas à Unidade Quirino de Machado (1984), de idade Paleoproterozóica (Valladares 1996). No Domínio Arrozal ocorrem rochas graníticas que compõem a Suite intrusiva Arrozal, enquanto no Domínio Serra das Araras afloram rochas metassedimentares, com ortognaisses e rochas graníticas subordinadas.

\section{Dominio Quirino}

Neste domínio podem ser individualizados dois tipos de foliação: uma foliação mais antiga, denominada $\mathrm{Sn}$, e outra mais nova, $\mathrm{Sn+1}$. A primeira foliação corresponde a um bandamento metamórfico diferenciado, caracterizado por leitos quartzo-feldspáticos, descontínuos, centimétricos a decimétricos, que se alternam com leitos máficos ricos em biotita e anfibólio, milimétricos a centimétricos, conferindo à rocha uma estrutura planar.

Associado a este bandamento, são encontradas dobras intrafoliais, apertadas a isoclinais, com charneiras espessadas e flancos adelgaçados. Neste sentido, este tipo de foliação pode ser considerado como bandamento transposto (Hobbs et al. 1976). A segunda foliação, menos penetrativa do que a anterior, é caracterizada por uma foliação descontínua, ao longo da qual ocorre o desenvolvimento de minerais máficos, sobretudo biotita.

O conjunto de dados da foliação Sn, para este domínio, mostra uma orientação principal N75E, com merguthos sub-verticais a moderados para NW (Fig. 3.3a). A foliação Sn+1 apresenta uma direção geral semelhante a foliação anterior, porém com uma disposição próxima de uma guirlanda, o que sugere a presença de dobras com orientação média de eixo S70W/10 (Fig. 3.3b). 


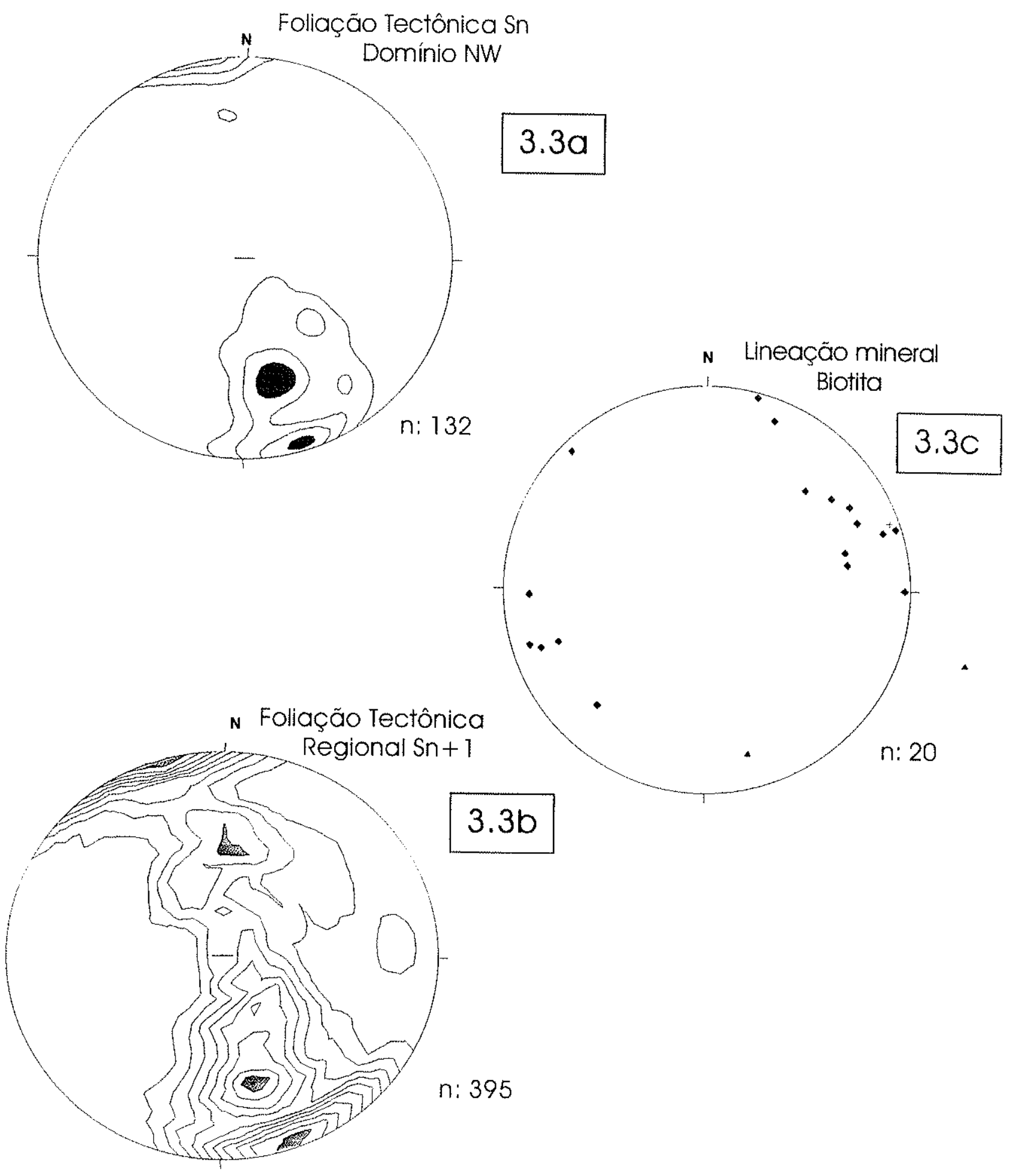

Fig. 3.3. Estereogramas para foliações e lineações tectônicas do Dominio Estrutural Quirino (NW), plotados em Diagramas Schimidt, hemisfério inferior. 
A configuração desta guirlanda encontra-se no limite de segmentos cilindricos e cônicos. Além disso, a existência de eixos de caimento suave sugere uma superfície anterior sub horizontal

Os dados de lineação mineral em biotita, contidos na foliação mais nova $\mathrm{S} n+1$, apresentam grande dispersão no estereograma, porém exibindo caimentos suaves para os quadrantes NE e SW (Fig. 3.3c). A lineação disposta em dois quadrantes é compatível com a existência da superposição de dobras com orientação axial NW. Além disso, notase uma distribuição da lineação ao longo de um círculo máximo (pouco visível no estereograma), evidenciando assim giro da mesma na superfície Sn+1 (Fig. 3.3c). Esta geometria pode ser atribuída a atuação de mecanismos de deformação não coaxial associados à geração das estruturas lineares.

\section{$\checkmark$ Dominio Arrozal (DA)}

Corresponde ao domínio ocupado pela Suite Intrusiva Arrozal (SIA). É caracterizado pelo desenvolvimento de dois tipos de foliações: uma magmática e outra deformacional. A primeira foliação é observada na porção sul deste domínio, sendo preservada da deformação principalmente nas porções centrais da SIA. Esta foliação possui orientação concordante e corresponde à foliação $S n+1$ dos gnaisses do domínio anterior.

A análise geométrica da foliação magmática define uma orientação média N45E com: mergulhos sub-verticais (Fig. 3.4a). Contudo, nota-se uma dispersão dos pólos na borda do estereograma num intervalo aproximado de $30^{\circ}$. A comparação destes dados com o estereograma da foliação $\mathrm{Sn+1}$ (Fig. 3.3b) sugere um giro desta foliação. Isto pode ser verificado no mapa estrutural (APÊNDICE 2), onde a geometria das foliações na porção sudoeste do DA é sub paralela ao padrão estrutural dos domínios adjacentes, notando-se uma mudança progressiva de orientação na porção noroeste do domínio. Esta relação geométrica é compativel com um movimento destral ao longo das duas zonas de cisalhamento que limitam o citado domínio.

A foliação tectônica apresenta-se concordante com as atitudes da foliação $S n+1$ do Domínio Quirino (NW) (Fig. 3.4c). 


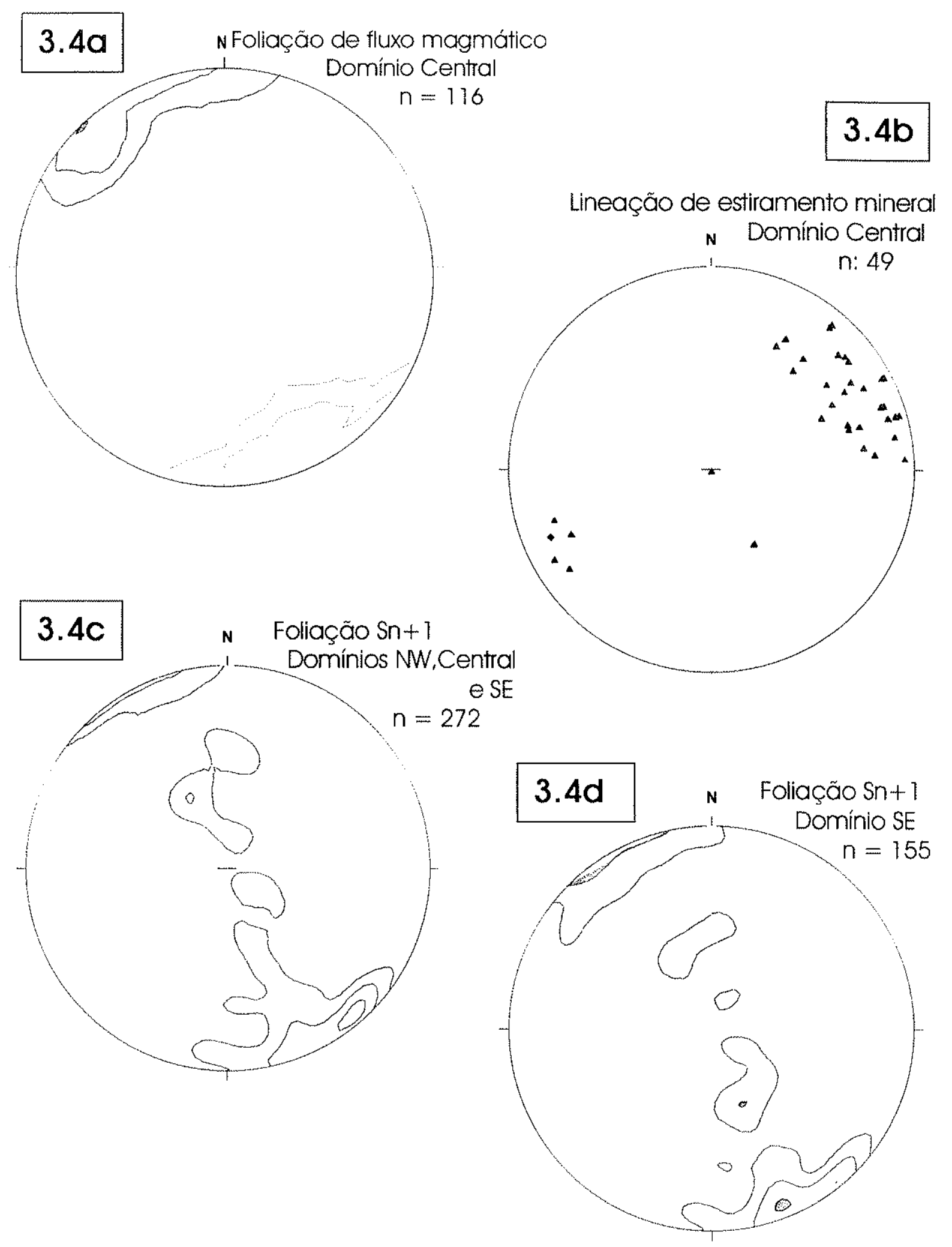

Fig.3.4. Estereogramas para foliaçōes e lineaçōes dos Domínios Estruturais Qurino (NW), Central e Serra das Araras (SE)., plotados em Diagramas de equi-área de Schimidt, hemisfério inferior. 
Os dados da lineação de estiramento mineral mostram uma concentração, dominante, no quadrante NE, e outra, secundária, no quadrante SE (Fig.3.4b), reflexo do baixo valor do ângulo de mergulho. A primeira delas apresenta dispersão acentuada segundo um círculo máximo, sugerindo um giro da mesma no plano de foliação. A relação geométrica entre a lineação e a foliação $\mathrm{Sn+1}$ (Fig.3.4c) é compatível com o predomínio de uma movimentação direcional.

\section{$\checkmark$ Dominio Serra das Araras (DSA)}

Corresponde ao domínio ocupado pelo prolongamento da Serra das Araras. O comportamento estrutural deste domínio é muito semelhante ao Domínio Quirino, sendo porém caracterizado apenas um tipo de foliação, que corresponde à foliação $S n+1$ do DSA.

A orientação geral da foliação é N69E, com mergulhos sub-verticais e moderados para NW (Fig. 3.4d). A distribuição dos pólos desta foliação, com máximos próximos às bordas e o centro do diagrama, sugere ou a existência de dobras regionais, ou de uma foliação anterior agora verticalizada pela superposição das zonas de cisalhamento de alto ângulo.

Os dados acima apresentados evidenciam uma boa correlação da trama estrutural entre os domínios Quirino e Serra das Araras, onde a foliação $S n+1$ exibe orientações semelhantes. Contudo, o estereograma do Domínio Quirino (Fig. 3.3b) indica a existência de dobras regionais, o que é confirmado pelas observações de campo.

Em suma, cabe aqui frisar, que o Domínio Arrozal, em relação aos domínios adjacentes, exibe uma orientação estrutural diferente na sua porção setentrional, com a foliação magmática formando um ângulo de cerca de $30^{\circ}$ entre a orientação preferencial NE / SW, e a orientação secundária ENE / WSW. Considerando que a orientação de um corpo associado a uma zona de cisalhamento traduz o comportamento da elipse de deformação regional, pode ser considerado que o alojamento da Suite Intrusiva Arrozal (SIA) ocorreu num quadro cinemático destral, e que é compativel com o modelo de Riedel. Esta hipótese é coerente com o modelo cinemático das transcorrências regionais, onde sistematicamente tem sido reportado movimentação destral para as mesmas 
(Almeida et al. 1973, Brenner et al. 1980, Campanha 1980 e 1981, Dayan \& Keller 1989, Ebert et al. 1991, Correa Neto et al. 1993, Sadowski 1993, Silva 1996).

\subsubsection{Marcadores cinemáticos do Domínio Arrozal}

Os principais marcadores cinemáticos identificados neste domínio foram lineações de estiramento mineral, foliação sigmoidal, franja de recristalização dinâmica simétrica (tipo "cometa"), rotação de feldspatos e granadas, pequenas zonas de cisalhamento dúcteis com movimentação destral e dobras assimétricas em $Z$ eixo SE, com vergência para SW (Fig.3.5).

Foram também observados marcadores cinemáticos nos granitos porfiriticos, associados constantemente aos corredores de cisalhamento, representados por "pods" de granito porfirítico em rochas miloníticas, porfiroclastos assimétricos tipo Sigma (Simpson 1983), pares S-C de foliações ou foliações pisciformes "foliation fishes" (Hanmer 1986), que mostram de forma consistente com outros indicadores uma cinemática predominantemente destral (Fig.3.6).

\subsubsection{Marcadores cinemáticos das rochas encaixantes (Domínios Quirino e Serra das Araras)}

Os marcadores cinemáticos das rochas encaixantes da SIA se caracterizam por dobras assimétricas, pares de foliações S-C, lineações de estiramento mineral, foliação sigmoidal, franjas assimétricas de recristalização dinâmica e pequenas zonas de cisalhamento dúcteis destrais e sinistrais (Fig.3.7).

\subsubsection{Padrão da Trajetória da Foliação Tectônica}

A estrutura mais evidente do Maciço Granítico Arrozal é uma foliação no estado sólido desenvolvida nas suas bordas, como resultado da movimentação das zonas de cisalhamento adjacentes.

Esta foliação tectônica, do centro para as bordas do maciço, torna-se progressivamente paralela às zonas de cisalhamento Além Paraíba e Mendes, bem como mostra uma mudança no seu padrão estrutural, passando de NE-SW, na parte sul do domínio, para ENE-WSE, na parte norte do mesmo. 


\section{Estruturas de fluxo magmático na Zona de Cisalhamento de Arrozal}

\section{Fig. 3.5}

MGA fácies foliada

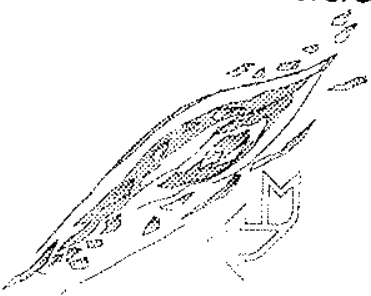

Foliação milonítica

preservada
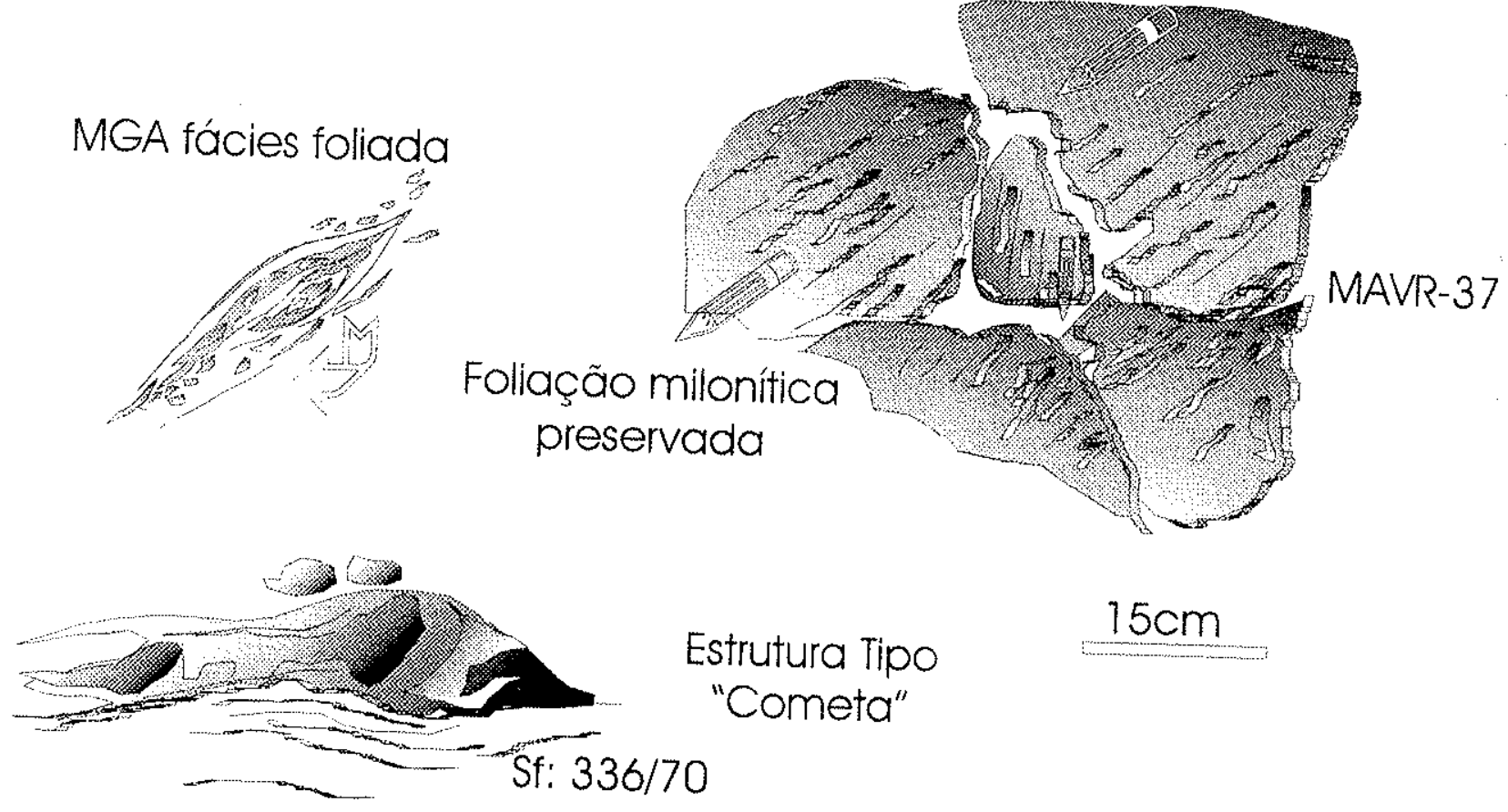

Fluxo ígneo e milonítico superimposto
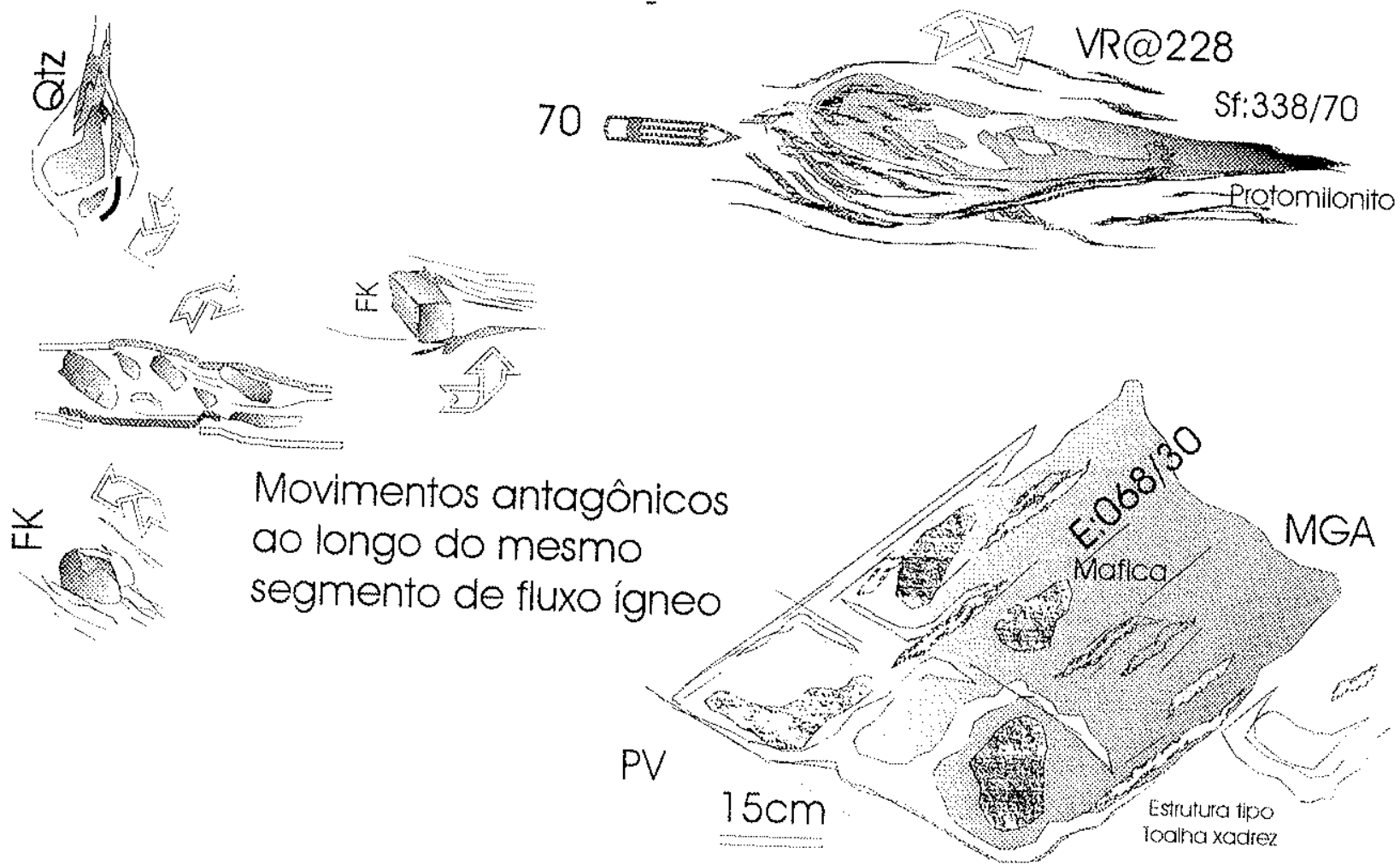

Obs: Algumas estruturas observadas frequentemente próximo à Zona de Cisalhamento de Arrozal, sugerem a contemporâneidade entre o cisalhamento $F 3$ e o alojamentro do magma granítico 


\section{Estruturas mesoscópicas}

Fig. 3.6

Estrias obliquas
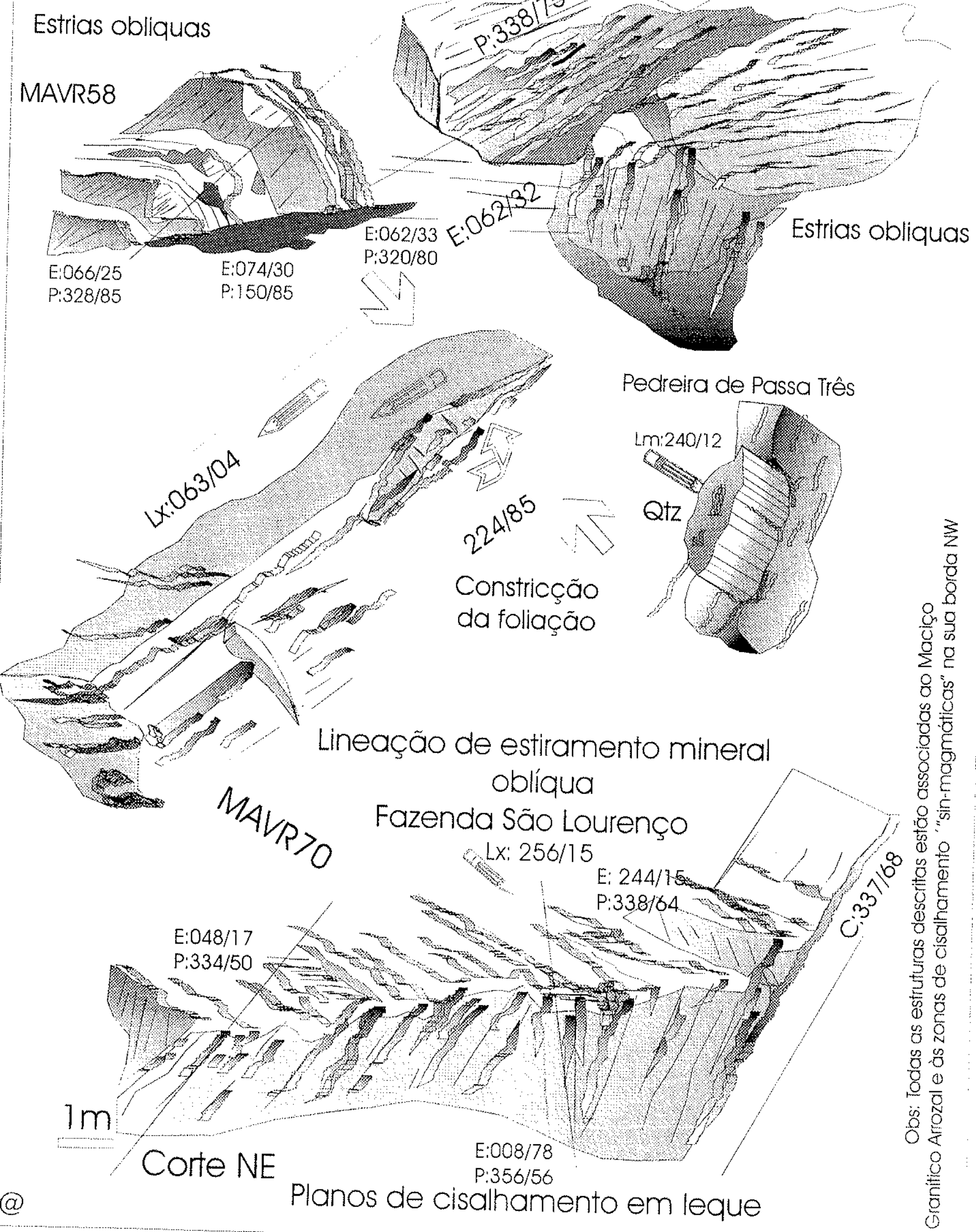


\section{Zonas de cisalhamento dúcteis}

Marcadores cinemáticos

\section{Fig. 3.7}

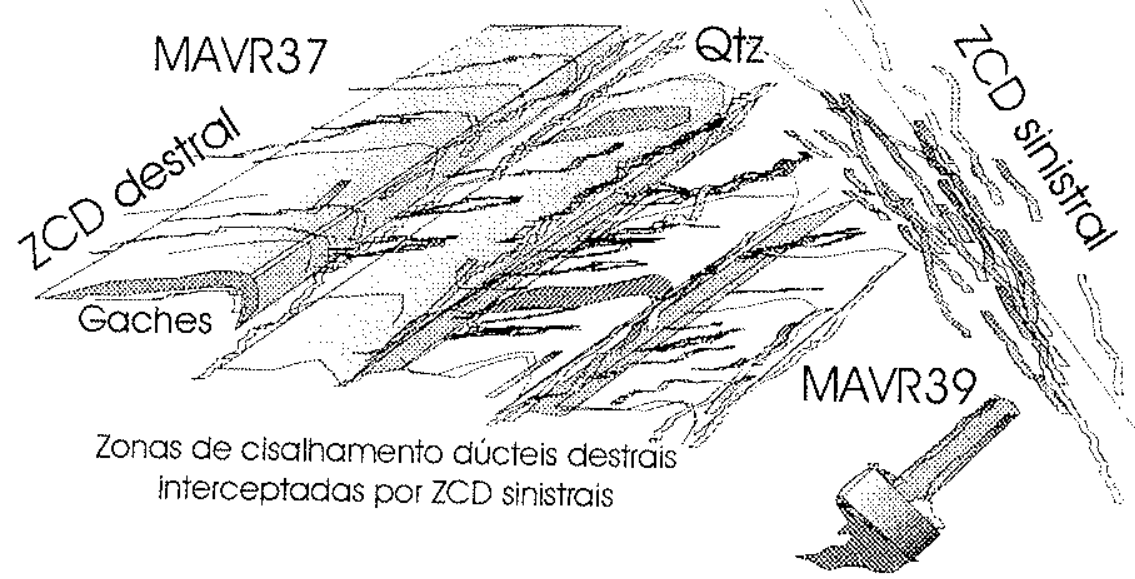

interceptadas por ZCD sinistrais

Boudins rotacionados LE
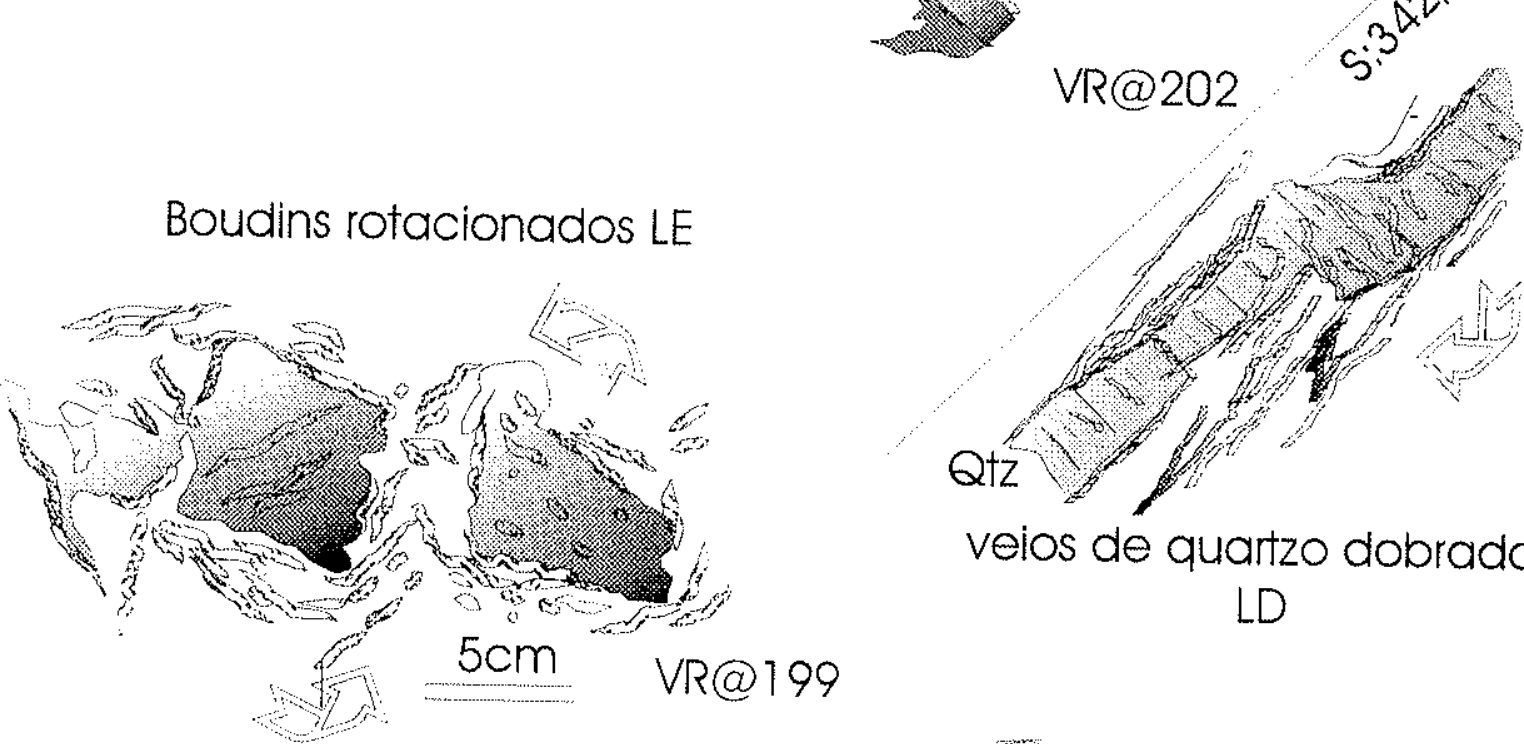

veios de quartzo dobrados

LD
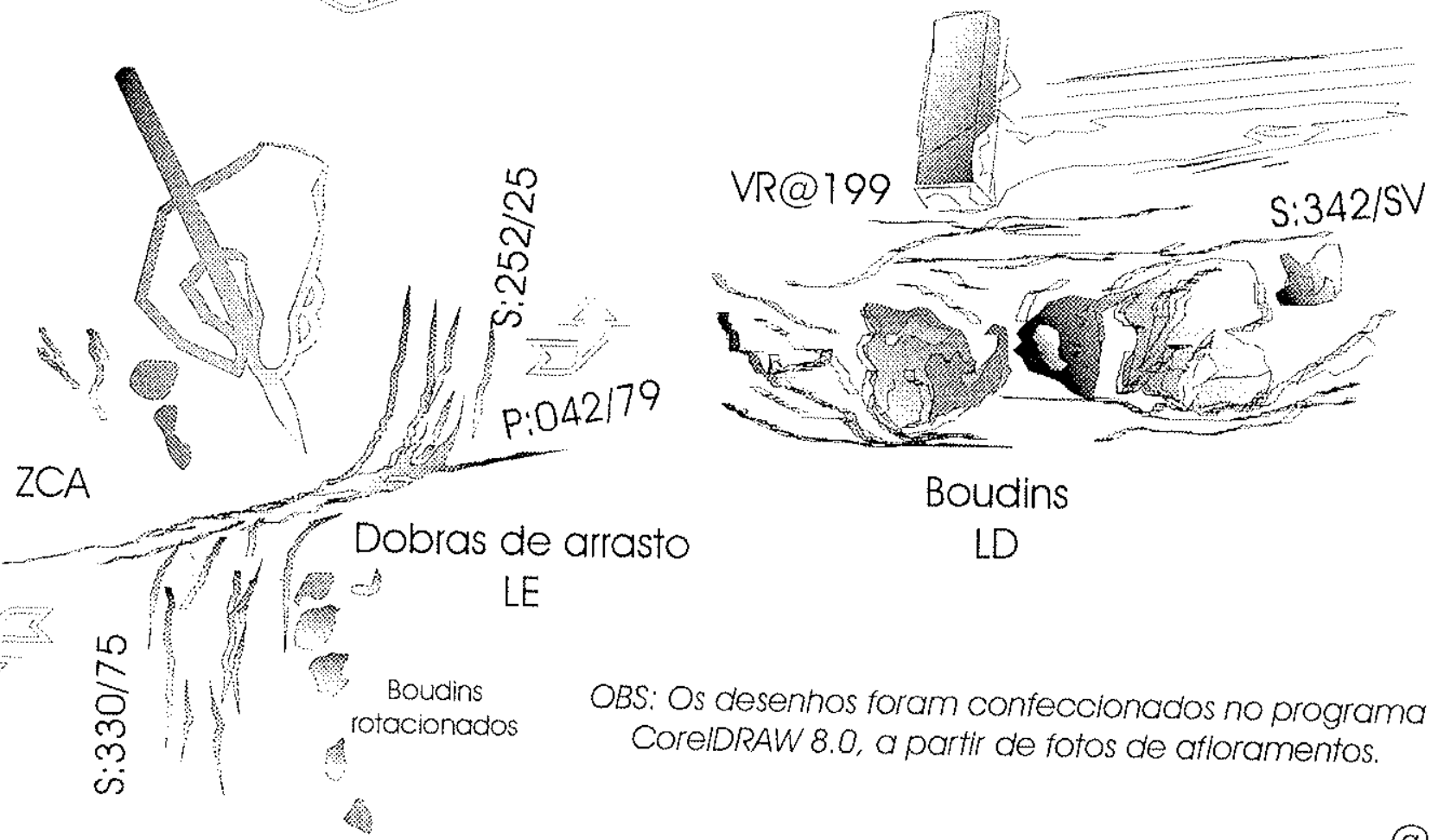

OBS: Os desenhos foram confeccionados no programa CorelDRAW 8.0, a partir de fotos de afioramentos. 


\subsubsection{Padräo da Trajetória da Lineaçäo Tectônica}

Estruturas lineares $(\mathrm{Ln})$, representadas por eixos de dobras $\mathrm{Dn}$, minerais prismáticos alinhados, eixos de crenulações assimétricas, dobras abertas $D n+1$, mostram-se em geral sub-paralelos às zonas de cisalhamento dextrais que limitam o Domínio Arrozal (APENDICE 2).

\subsubsection{Relações entre deformaçăo e metamorfismo}

As rochas estudadas dos Domínios Serra das Araras e Quirino apresentam paragêneses com sillimanita (fibrolita) + feldspato alcalino, sem a presença de moscovita estável, caracterizando assim metamorfismo do grau forte de Winkler (1976), sob condições de pressão intermediária.

Os gnaisses destes domínios possuem paragêneses com plagioclásio + microclínio + quartzo +- granada +- moscovita, e hornblenda + plagioclásio + clinopiroxênio + quartzo. A desestabilização de granada para epídoto e clinozoizita, hornblenda para biotita, epídoto em titanita; biotita para moscovita e minerais opacos, é indicativo da existência de um evento retrometamórfico a partir de uma paragênese anterior em grau alto. O evento aqui descrito parece corresponder ao terceiro evento metamórfico descrito para rochas do Complexo Paraíba do Sul mais a norte, nas regiões de Valença e Vassouras (Machado 1984 e Machado \& Oliveira 1986).

Os gnaisses apresentam localmente variações composicionais, que se refletem também em um aparente grau metamórfico mais elevado (em áreas do Domínio Quirino), onde atingem a fácies granulito de Winkler (op. cit.), com o aparecimento de paragêneses com ortopiroxênio (hiperstênio) + hornblenda + biotita +- titanita + quartzo + plagioclásio + microclínio. Estas rochas apresentam também evidências retrometamórficas com a desestabilização de ortopiroxênio para hornblenda, de hornblenda para biotita, ou ainda desta última para moscovita e clorita. 


\section{Considerações Preliminares}

A comparação entre as estruturas (magmáticas e deformacionais) descritas nas diferentes escalas (meso e micro) permitiu evidenciar alguns aspectos que serão a seguir examinados. Inicialmente, cabe salientar a existência de cristais de feldspatos potássico (microclínio) sem evidências claras de deformação importante, a não ser o da inversão de ortoclásio para microclínio, que tem sido geralmente explicado pela deformação no estado sólido (Eggleton \& Buseck 1980).

A presença de grãos de quartzo com extinção ondulante generalizada e formação de sub grãos com poligonização localizada sugere a existência de deformação no estado sólido. Além disso, a presença de mirmequitas preservadas da deformação é indicativo da reação plagioclásio e feldspato potássico em condições de temperaturas moderadas e pressões elevadas.

As estruturas ígneas da parte central do Maciço Arrozal são afetadas localmente por deformações incipientes no estado sólido.

Durante a colocação do MGA, as pequenas diferenças reológicas então existentes em relação aos domínios estruturais sugerem que o nível de colocação do maciço granítico ocorreu próximo de sua geração, ou seja não houve um grande deslocamento do corpo. 


\section{CAPITULO 4}

\section{Quimica Mineral e Geoquimica}

Este capítulo tem como objetivo definir as caracteristicas do magmatismo granítico da Suite Intrusiva Arrozal (SIA), a partir de dados petrográficos, geoquímicos de elementos maiores, traços e de terras raras, realizados nos laboratórios ACTLABS (Ontário, Canadá) e na École des Mines de Saint Etienne (EMSE - França); e de química mineral Universidade Federal do Rio Grande do Sul (UFRGS). Após a integração e organização, os dados foram plotados em diagramas tipo Harker, classificatórios e discriminantes de ambientes tectônicos nos programas Min Pet e Excell.

\section{Química Mineral}

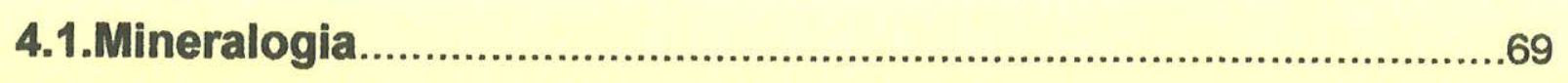

Introduçăo

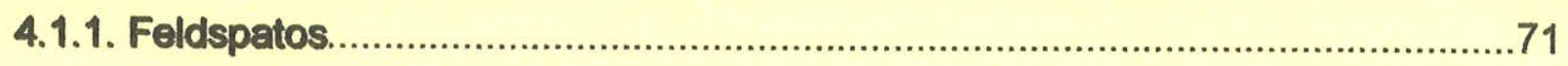

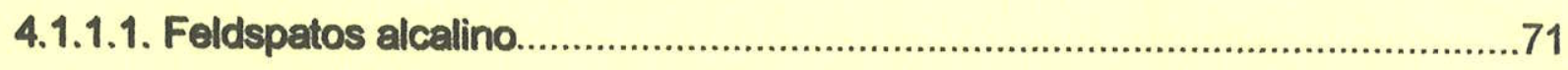

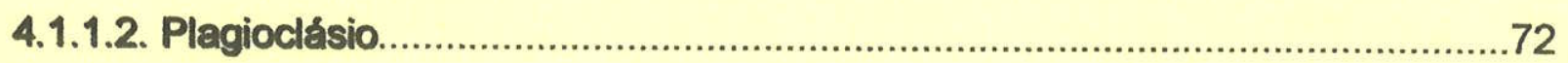

4.1.1.3. Micas

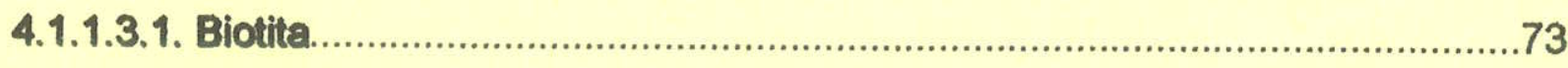

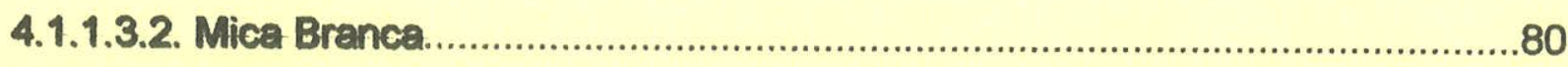

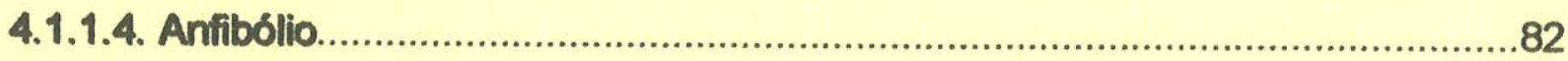

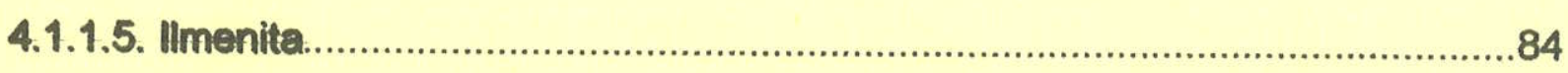

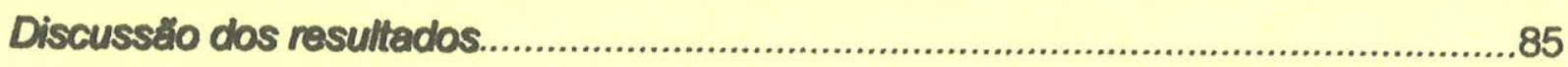




\subsection{Mineralogia}

\section{Introdução}

Para o estudo da química mineral foram selecionadas, com base em critérios mineralógicos, petrográficos e faciológicos, um total de 12 amostras representativas das diferentes faciologias do maciço, cuja localização encontra-se na Figura 4.1. As tabelas com os dados químicos podem ser analisadas no final deste capítulo. As análises foram realizadas na Microssonda Eletrônica da Universidade Federal do Rio Grande do Sul, cujas características de operação do equipamento foram as seguintes:

Voltagem de aceleração: $15 \mathrm{keV}$; Feixe de corrente: $\sim 20.10^{ \pm} 0.10 \mu$; Tempo de contagem médio: 30s; Diâmetro do feixe: $1 \mu \mathrm{m}$ para magnetita e ilmenita; $5 \mu \mathrm{m}$ para biotita, anfibólio e feldspato alcalino; $10 \mu \mathrm{m}$ para plagioclásio.

As amostras analisadas fazem parte das seguintes faciologias: fácies porfirítica (MGA), 4 amostras; fácies quartzo monzonito leucocrático, 2 amostras; fácies foliada (MGA), 20 amostras, sendo que, foram incluídas neste grupo as porções bandadas e leucograníticas que representam as porções marginais deformadas da fácies porfirítica do MGA.

O Maciço Granítico Arrozal (MGA) apresenta composição granodiorítica e subordinadamente monzogranítica. Possui granulação média, inequigranular, porfirítica na porção central e foliado nas porções marginais.

Apresenta como minerais essenciais feldspato alcalino (ortoclásio e microclina), em geral como megacristais (porcentagem entre 5 a 10\% do volume da rocha), plagioclásio de composição oligoclásio/andesina, quartzo, anfibólio e biotita (siderofilita) como principal mineral máfico. Ocorrem como minerais acessórios apatita, ilmenita e zircão, e, mais raramente, granada e turmalina.

Os minerais de alteração são representados por clorita e moscovita associadas à biotita, em ambos os casos correspondendo a paragêneses tardias, ligadas à interação de uma fase fluida. Os feldspatos podem ser micropertíticos e, localmente, microantipertíticos. 


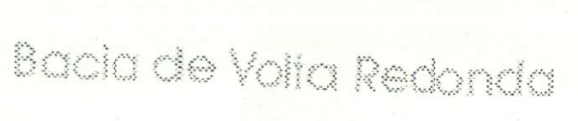
$\mathrm{KP} D \mathrm{DP}$
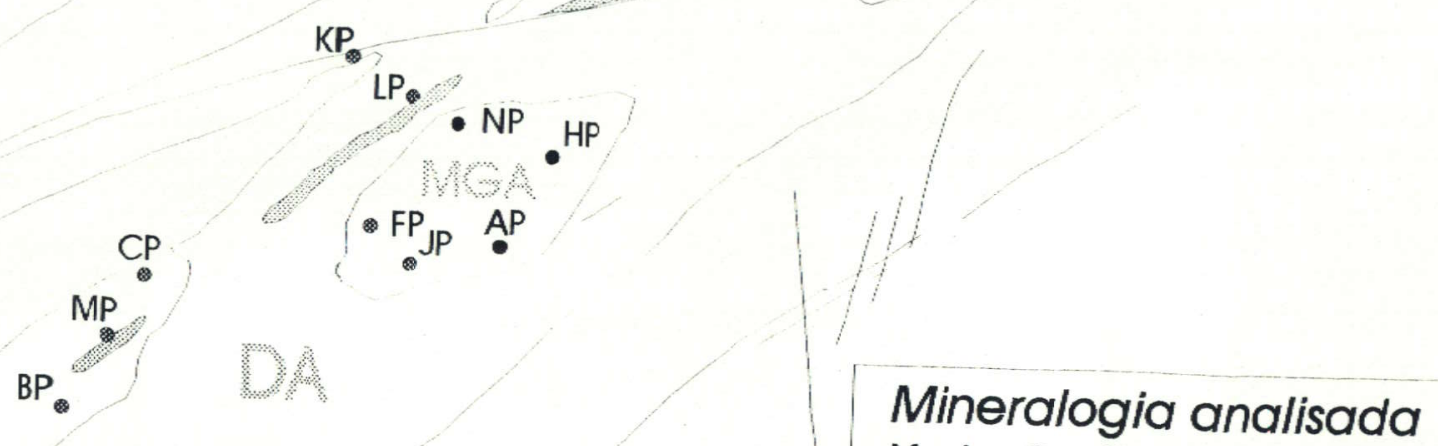

Maciço Granítico Arrozal (GVR) e fácies foliada: plg, bł e kf NP(VR@224); HP(MAVR106); FP(MAVR59b); AP(MAVR34)

Quartzo-Monzonito(LVR): anf, plg, msc, kf

LP(MAVR33A); KP(MAVR61); DP(VR@227)

Rochas básicas(BVR): plg, bt, anf, px

MP(ARVR1 11 A - diorito); JP(MAVR97A) - enclave

Maciço Granítico Getulândia (GPR): bł, kf, plg, ilm.

CP (GVR001); BP (ARVR111); IP (VR@121

Unidade Quirino (QVR): bt, hbl, plg, ilm QP(VR@204)

Figura 4.1 - Localização das amostras utilizadas nos estudos de química mineral da Suíte Intrusiva Arrozal, onde podem ser destacados três setores principais : Maciço Granítico Arrozal (MGA); Maciço Granítico Getulândia (MGG)
e setor deformado (fácies folida) 


\subsubsection{Feldspatos}

A fórmula estrutural dos feldspatos foi calculada com base em 32 oxigênios (Deer et al. 1982) podendo ser escrita genericamente como:

$$
\left(A^{+1} A^{+2}\right)\left(B_{2-x}^{+3} B^{+4}{ }_{2-x}\right) O_{8} \text {, para } 0<x<1
$$

Estes feldspatos são representados pelo feldspato alcalino (ortoclásio e microclina) e plagioclásios, que são descritos abaixo.

\subsubsection{Feldspato alcalino}

Ao microscópio, o feldspato alcalino das fácies porfirítica e foliada do MGA ocorre como megacristal subedral e como integrante da matriz. Nesta, possui forma subedral a anedral, aparecendo também como inclusões sub arredondadas no plagioclásio. Os primeiros apresentam-se como cristais límpidos com tamanho de até $5 \mathrm{~cm}$ e caracterizamse como ortoclásio. Na matriz, entretanto, mudam sua forma estrutural, aparecendo como cristais de microclínio. Na fácies leucogranítica, equigranular, o feldspatos alcalino é micropertítico e ocorre como cristal subedral, de dimensões entre 0,5 a $1,5 \mathrm{~mm}$. A sua composição na fácies porfirítica situa-se próximo ao pólo do ortoclásio no diagrama triangular Or - Ab - An, com os valores de moléculas de Albita sempre inferiores a $20 \%$ (Fig. 4.2 $2^{1}$. Na fácies foliada, a composição do feldspato alcalino é sempre inferior - valor em Or da fácies leucogranitica. Foram observadas pequenas variações composicionais centro-borda nos feldspatos alcalinos (Tab.4.1), (teores em Ca mais elevados no núcleo).

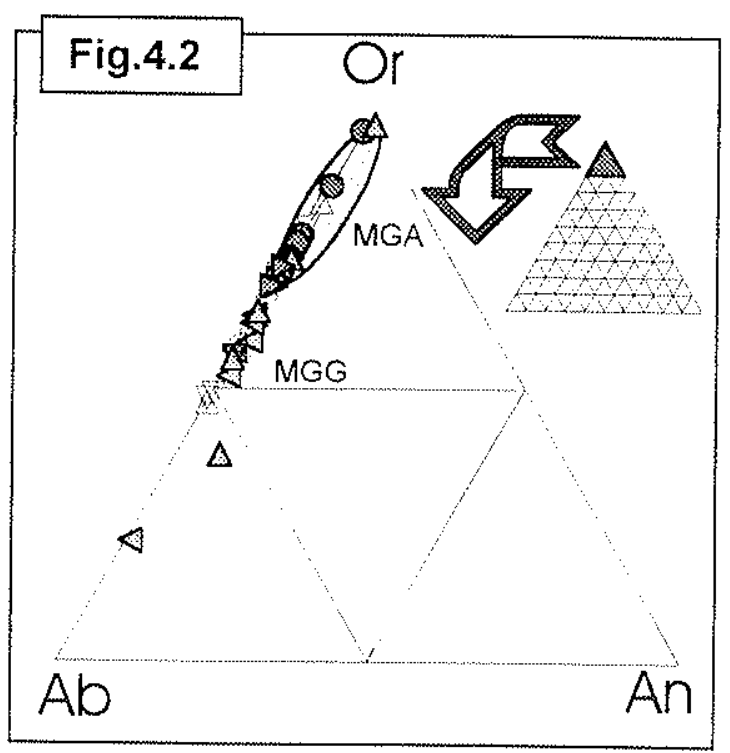

\footnotetext{
${ }^{1}$ Diagrama triangular onde a fácies porfiritica (círculos cheios) do MGA, possui valores superiores de Or quando comparado ao MGG (triângulos vazados) e fácies leucogranitica (triângulo cheio)
} 


\subsubsection{Plagioclásios}

Os plagioclásios das faciologias do MGA, em lâmina delgada, ocorrem principalmente como integrantes da matriz. São cristais de tamanhos variáveis entre 1 a $4 \mathrm{~mm}$., com geminação polissintética da albita, não zonados, com graus variáveis de saussuritização. Nas porções mais deformadas da fácies foliada, apresentam geminações polissintéticas em cunha. Ocorrem como grãos límpidos, euedrais a subedrais, às vezes arredondados, como integrantes da matriz ou intersticiais.

Os dados de química mineral permitiram separar três grupos composicionais de plagioclásio (Tab.4.2): o primeiro grupo, que apresenta composição albítica, é representado pelas fácies leucogranítica (MGA) e por gnaisses do Domínio Quirino; o segundo grupo, de composição andesina, é composto pelas fácies porfirítica e foliada e enclave quartzo diorítico do MGA e pelos diques de diorito que o cortam; o terceiro grupo é composto por plagioclásios de composição anortítica, é oriundo de amostras de diques e enclaves dioríticos (composição labradorita), e plagioclásios de composição bitownita, provenientes de amostras de diques dioríticos associados ao MGG.

A amostra de enclave, de composição anortítica, possui quantidade anômala em sódio (entre 6,9 a $7,2 \%$ ). Os plagioclásios presentes nas micropertitas têm composição mais cálcica.

De modo geral, os megacristais têm composições menos sódicas do que os cristais da matriz, em uma mesma faciologia, bem como as bordas dos cristais da matriz sendo mais sódicas que seus núcleos (Tab.4.2).

\subsubsection{Micas}

A fórmula estrutural das micas foi calculada com base em 22 oxigênios (Deer et al. 1982), com a fórmula geral sendo expressa como:

$$
\begin{aligned}
\left(\mathrm{X}_{2} \mathrm{Y}_{4-6}\right. & {\left[(\mathrm{Si} \mathrm{Al})_{8} \mathrm{O}_{20}\right](\mathrm{OH}, \mathrm{F})_{4} \text { onde } } \\
\mathrm{X} & =\mathrm{K}, \mathrm{Na}, \mathrm{Ca}(\mathrm{Ba}, \mathrm{Rb}, \mathrm{Cs}) \\
\mathrm{Y} & =\mathrm{Al}, \mathrm{Mg}, \mathrm{Mn}(\mathrm{Mn}, \mathrm{Cr}, \mathrm{Ti}, \mathrm{Li}) \\
\mathrm{Z} & =\mathrm{Si}, \mathrm{Al}\left(\mathrm{Fe}^{3+}, \mathrm{Ti}\right)
\end{aligned}
$$




\subsubsection{Biotita}

A fórmula estrutural da biotita, calculada numa base anidra de 22 oxigênios (Deer et al. 1982), pode ser descrita genericamente como:

$$
\mathrm{K}_{2}\left(\mathrm{Mg}, \mathrm{Fe}^{2+}\right)_{6-4}\left(\mathrm{Fe}^{3+}, \mathrm{Al}, \mathrm{Ti}\right)_{0-2}\left[\mathrm{Si}_{6-5} \mathrm{Al}_{2-3} \mathrm{O}_{20}\right](\mathrm{OH}, \mathrm{F})
$$

Foram analisadas 10 amostras das faciologias (incluindo enclave) do MGA (6), MGG (1), diques básicos (2) e de ortognaisse do Domínio Quirino (1) (Tabelas 4.3 a 4.6).

A biotita é o principal mineral máfico presente nas diferentes faciologias dos maciços, com teores entre $0,5 \%$ (fácies leucogranítica do MGA) a 20\% (fácies foliada do MGA), sendo porém mais comum com teores entre 10 e $15 \%$.

Microscopicamente, as biotitas estudadas possuem características ópticas distintas nos dois maciços: no MGA apresentam pleocroísmo de marrom-avermelhado a pardoesverdeado e no MGG de verde-claro a verde-escuro. Em ambos os maciços, elas possuem tamanho entre 1 e $3 \mathrm{~mm}$.

Ocorrem em agregados na matriz ou como cristais intersticiais ao redor de megacristais de feldspatos (potássico e plagioclásio).

Nos diques básicos e enclaves, elas ocorrem como cristais intersticiais, esparsos, com tamanho sub milimétrico, parcial ou totalmente cloritizadas ou como agregados intersticiais associados com minerais opacos, hornblenda, clorita e mica branca secundária. Em algumas amostras, observa-se a alteração para mica branca e clorita.

\section{$\checkmark$ Classificaçäo}

As análises de biotitas apresentam composição annítica nos diques máficos, e na fácies porfiritica e foliada mostram-se menos enriquecidas em FeO do que na fácies leucogranítica. O trend evolucional destas biotitas (Fig.4.3a) indica um caráter mais evoluído para a fácies leucogranítica.

No diagrama triangular $10^{*} \mathrm{TiO} 2$ vs. FeO + MnO vs. MgO de Nachit et al. (1986), proposto para discriminar biotitas primárias e secundárias, as biotitas estudadas (SIA) ocupam predominantemente o campo de biotitas primárias (a) (Fig. 4.3b). Porém, de acordo com a proposta de Abdel-Rahman (1994)(Fig.4.3c), os teores de $\mathrm{Al}_{2} \mathrm{O}_{3}$ nas biotitas das faciologias porfirítica e foliada (entre 17-18\%) se encontram no limite entre os grupos 


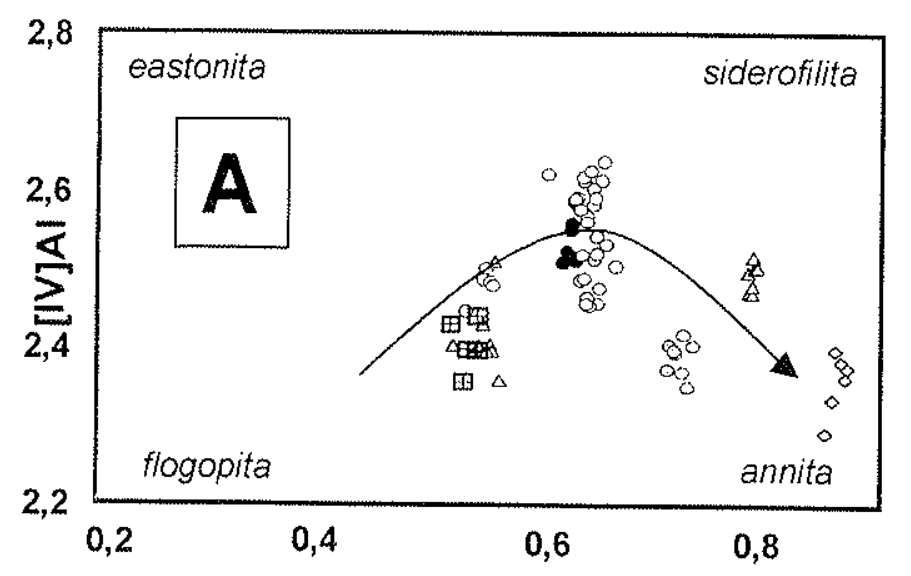

Fet / Fet+Mg

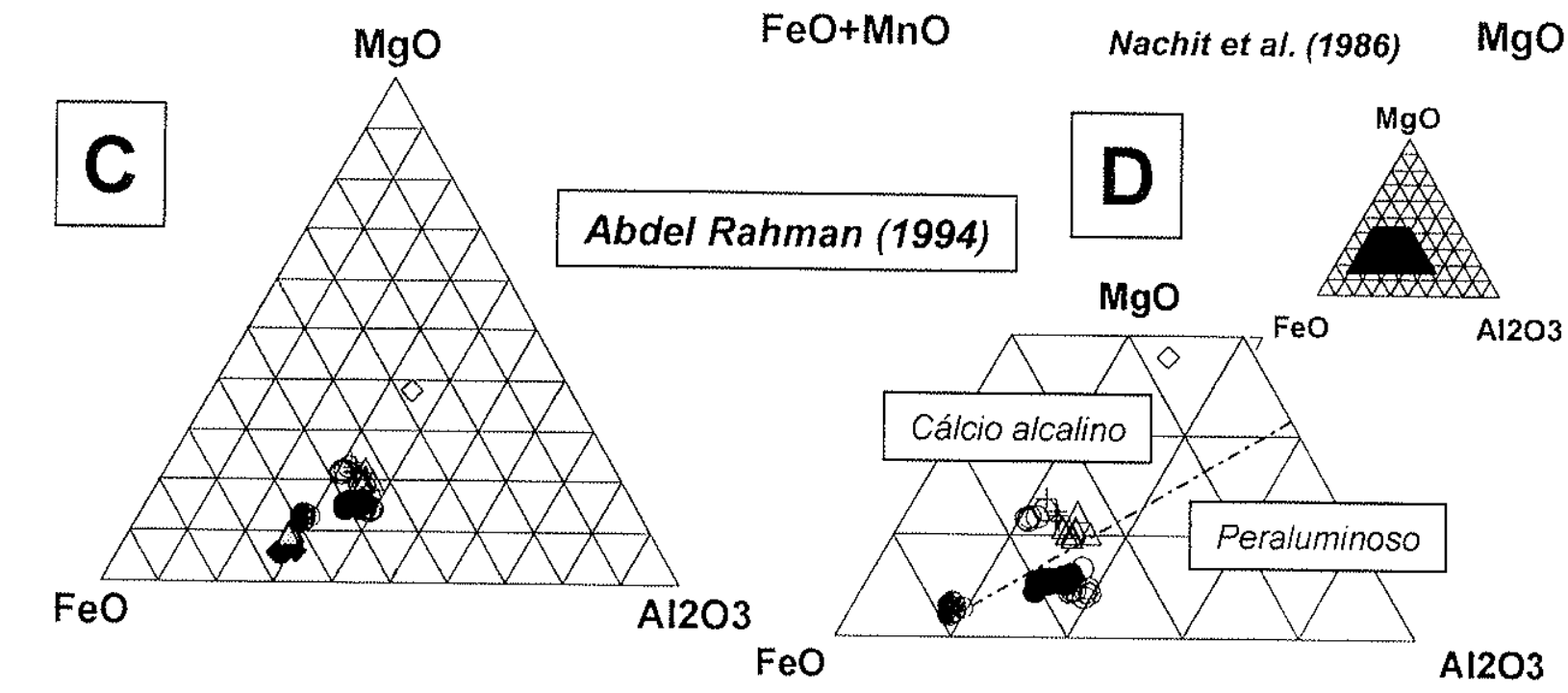

$\mathrm{FeO}+\mathrm{MnO}$
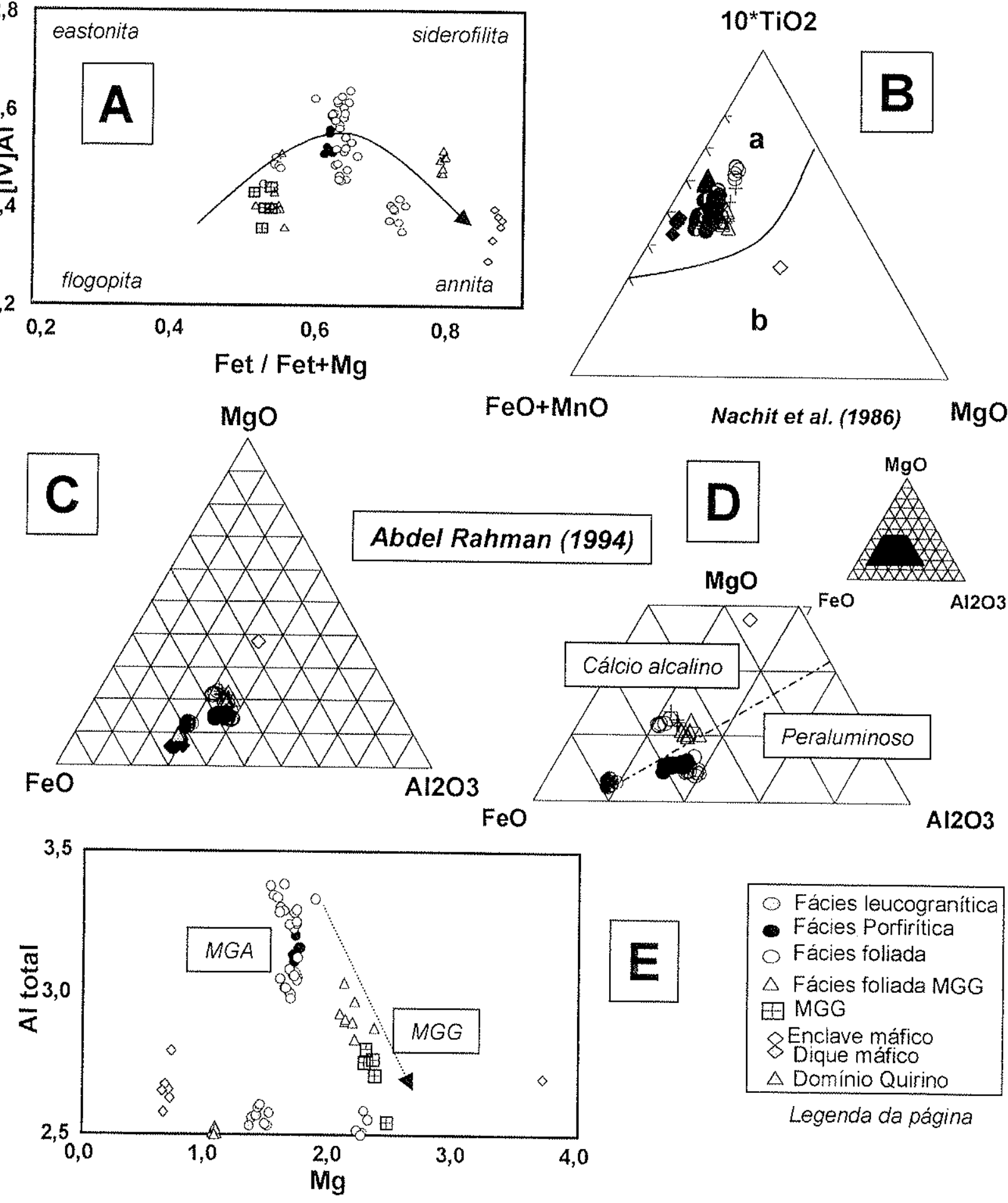

Nachit et al.(1986) MgO

Figura 4.3. Distribuição das biotitas e classificação segundo Nachit et al. (1986). onde as biotitas são classificadas como primárias (a) e secundárias (b). As biotitas das diferentes faciologias da Súte Intrusiva Arrozal e rochas hospedeiras caem sistematicamente no campo das biotitas primárias. Na classificação de Abdel-Rahman (1994) diagramas C e D as biotitas plotam no campo peraluminoso (fácies porfiritica e foliada do MGA) enquanto as biotitas do MGG situam-se no campo cálcio alcalino. 
de biotitas primárias (magmáticas) e secundárias (alteração), sendo este campo representado pelas biotitas que sofreram modificações composicionais por processos de substituições associadas a fluídos do período tardi- a pós-magmático.

$\mathrm{Na}$ fácies foliada a composição das biotitas analisadas permite distinguir dois grupos de biotitas: um grupo de biotitas magmáticas e outro de biotitas alteradas. $O$ primeiro grupo, muito férrico (annita), com cristais límpidos e alongados, caracteriza-se por teores de $\mathrm{Al}_{2} \mathrm{O}_{3}$ entre 13,90 e 14,29 de $\mathrm{MgO}$ entre 9,70 e 10 e $\mathrm{TiO}_{2}$ entre 4,81 e 5,87 (Tabelas 4.3 a 4.6). Este grupo é considerado como magmático e, portanto, o seu quimismo deve refletir a composição quimica do líquido que the deu origem. O segundo grupo, mais comum do que o anterior, caracterizado por composição siderofilita, apresenta teores em $\mathrm{Al}_{2} \mathrm{O}_{3}$ entre 17,56 e 18,95, $\mathrm{MgO}$ entre 6,36 e 8,18 e $\mathrm{TiO}_{2}$ entre 2,64 e 3,85. Este grupo é texturalmente diferente das biotitas do primeiro grupo, apresentando-se como lamelas de contornos corroídos, orientadas segundo a foliação milonítica. Pelo exposto, sugere-se que as diferenças composicionais apresentadas pelas biotitas do segundo grupo estão relacionadas a processos de deformação que afetaram o MGA (Fig.4.3e).

Um outro grupo de biotitas analisadas, pertencente às rochas encaixantes (Domínio Quirino) dos maciços graniticos, caracteriza-se pelos elevados teores em $\mathrm{FeO}, \mathrm{TiO}_{2}$, e mais baixos em $\mathrm{SiO}_{2}$ e $\mathrm{MgO}$.

Os grupos de biotitas, em geral, apresentam razão $\mathrm{Fe} \#(\mathrm{Fe} /(\mathrm{Fe}+\mathrm{Mg})$ entre 0,3 a 0,9, com valores aproximadamente constantes $(2,5)$ para $\mathrm{Al}^{\mathrm{IV}}$ (Tabelas 4.3 a 4.6). No diagrama $\mathrm{Al}^{\mathrm{IV}}$ vs. Fe \#, as biotitas do MGA caem no campo das micas aluminosas a ligeiramente férricas ( $\mathrm{Il}^{\mathrm{IV}}$ 2,8 e $\mathrm{Fe}$ \# 0,65, situando-se entre os campo da annita e siderofilita), enquanto aquelas do Domínio Quirino e do MGG mostram-se mais magnesianas (AlV entre 2,4 e 2,6 e Fe \# entre 0,5 e 0,85), situando-se entre os campos da flogopita e eastonita (Fig.4.3a).

As biotitas do enclave máfico (MP) e do corpo diorítico da Pedreira de Getulândia (BP) dispõem-se no campo da annita (Fig.4.3a). 


\section{$\checkmark$ Variaçöes composicionais}

Os dados revelam uma forte correlação inversa linear entre os conteúdos de Al e Mg; as biotitas do MGA (amostras FP, LP, EP e IP) possuem teores de Al superior a $3 \%, \mathrm{Mg}$ $<2 \%$, enquanto as biotitas do MGG (amostras CP, NP e LP) apresentam valores em Al inferiores a $3 \%$ e em Mg superiores a $2 \%$ (Fig.4.4a).

O conteúdo de $\mathrm{Mg}$ é mais elevado nas biotitas do enclave máfico (amostra JP) $(2,8 \%$ em Al e 3,7\% em Mg) e mais empobrecido em Mg ( 1\%) nas biotitas do Domínio Quirino, do MGG (GP, DP e BP, respectivamente) e no quartzo-monzonito do MGA (Fig.4.4a).

Há uma tendência de diminuição no conteúdo de $\mathrm{Cr}+\mathrm{Al}+\mathrm{Ti}(\mathrm{R} 2)$, com um aumento e $\underline{\mathrm{Mg}}+\mathrm{Fe}^{+2}$ e Mn (R3), na direção das biotitas do MGG (Fig. 4.4b). A razão $\underline{\mathrm{Al}^{\mathrm{IV}} \text { Vs. FeOt / }}$ $(\mathrm{FeOt}+\mathrm{MgO})$ nas biotitas do $\mathrm{MGA}$ varia de 0,6 a $0,7 \%$, sendo estes valores ligeiramente mais elevados do que os apresentados pelo MGG (entre 0,5 a $0,6 \%$ ). As biotitas do Domínio Quirino destacam-se pelo valor anômalo da Fe\# (0,8\%) (Fig.4.4c).

\section{$\checkmark$ Diagramas discriminantes}

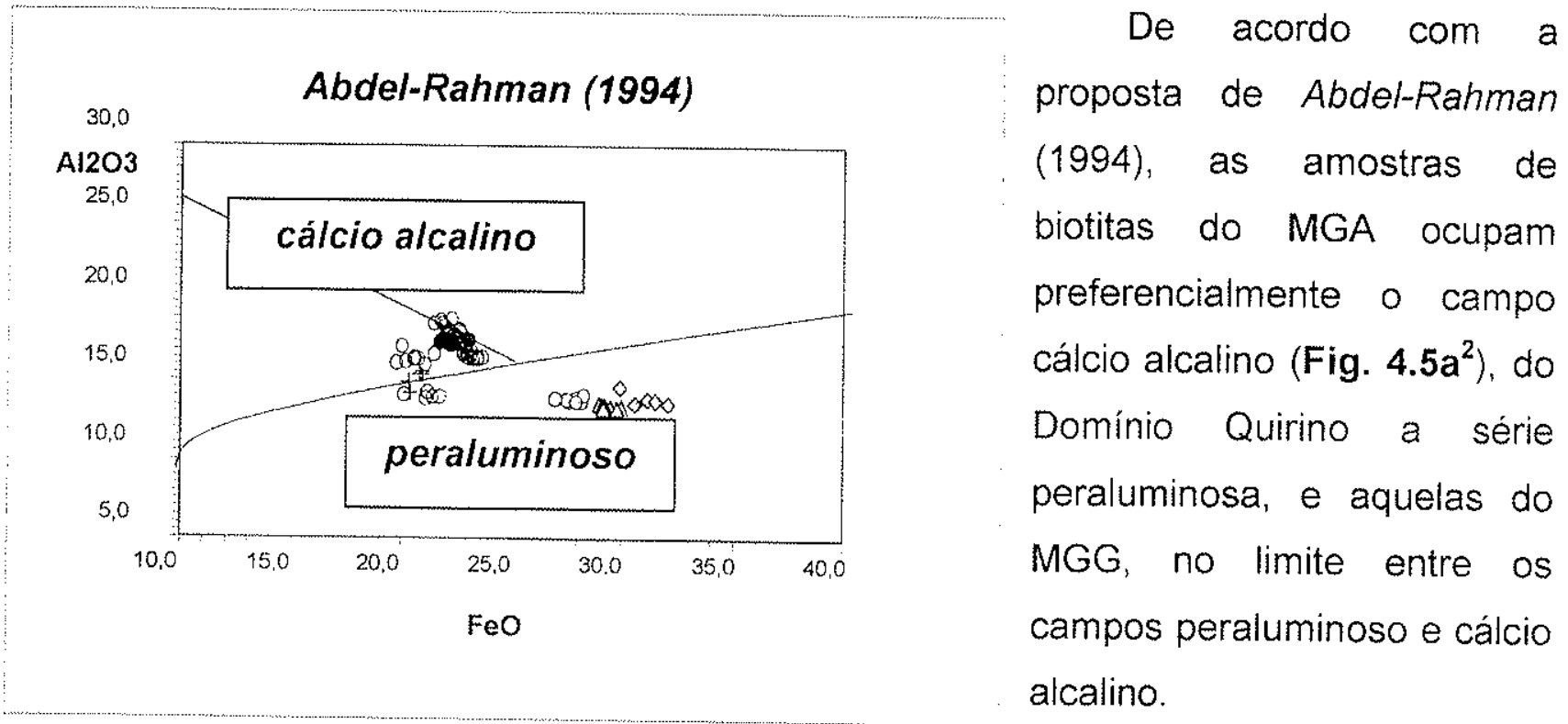

\footnotetext{
${ }^{2}$ Diagrama de classificação $\mathrm{Al}_{2} \mathrm{O}_{3}$ vs. FeO, para biotitas proposto por Abdel-Rahman (1994), onde estão representados os campos cálcio alcalino e peraluminoso, legenda na Fig.4.4.
} 


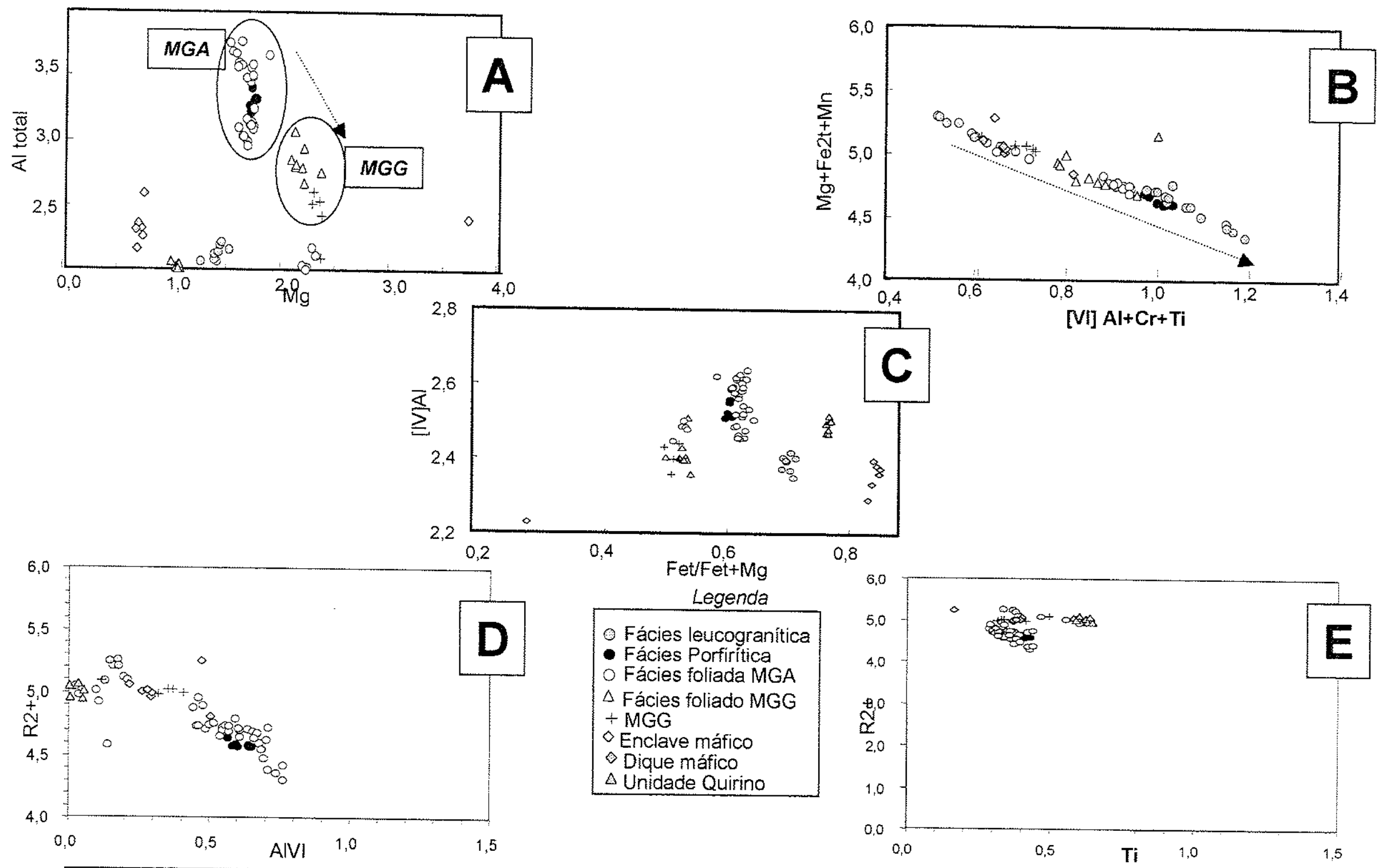

Figura 4.4 - Diagramas de classificação e substituição em biotitas $R^{+2}$ vs. $R^{+3}(B)$ apresentando o comportamento do $A l$ total vs. $M g(A)$, e parâmetros de Mg\# e indice de alcalinidade para os Domínios Arrozal (MGA e MGG), Quirino e rochas básicas. 
No diagrama de Chevremont et. al. (1998) observa-se que as amostras de biotitas do MGA situam-se, parte no campo da série aluminosa, e parte no campo da série cálcio alcalina, com algumas amostras atingindo o campo sub alcalino. As amostras dos diques, do Domínio Quirino e da fácies leucogranítica do MGA caem no limite dos campos sub alcalino e alcalino, evidenciando teores mais elevados em FeOt. As amostras do MGG ocupam, em sua maioria, o campo cálcio-alcalino (Fig. 4.5 $b^{3}$ ).

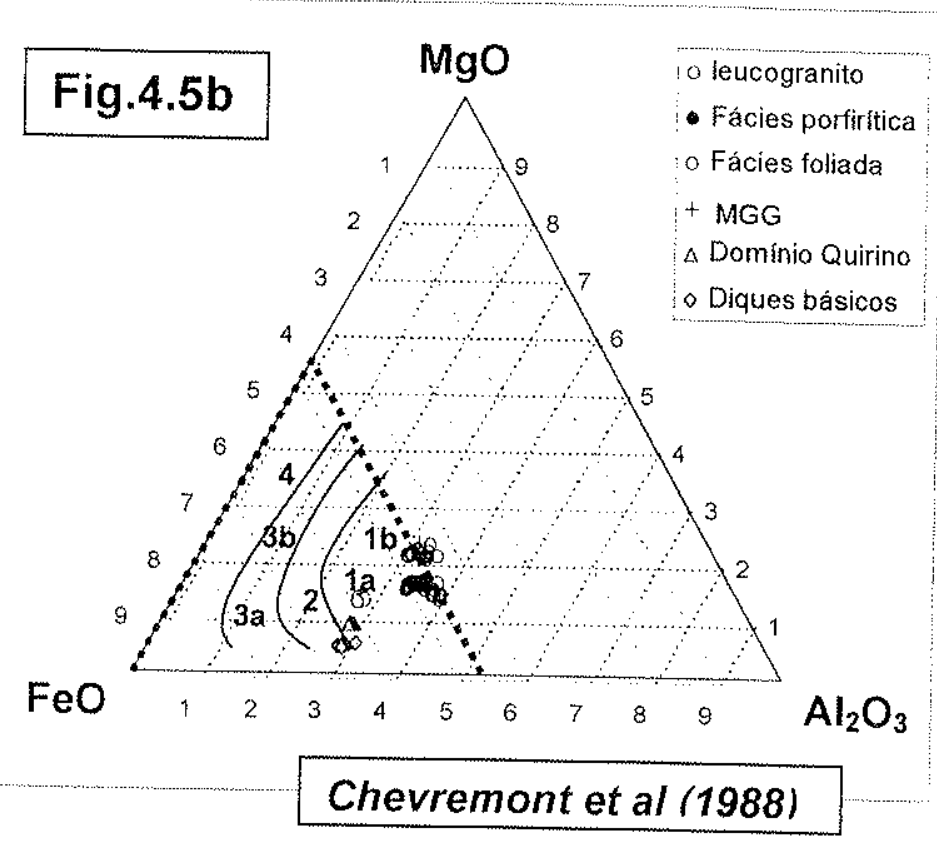

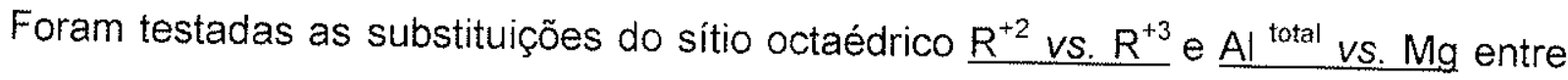
elementos e grupos de elementos químicos componentes das biotitas da SIA.

O gráfico $\mathrm{R}^{2+}$ vs. $\mathrm{R}^{3+}$ apresenta uma ótima correlação linear negativa, indicando a existência de substituições entre os elementos $R^{2+}\left(F e^{2+}+M n+M g\right)$ e $R^{3+}\left(A l^{V 1}+T i+C r\right)$ (Fig.4.4b), de acordo com a seguinte equação:

$$
\mathrm{Si}^{\mathrm{iV}}+\mathrm{R}^{2+}=A I^{\mathrm{iV}}+\mathrm{R}^{3+}
$$

Analisando os gráficos de substituição $\mathrm{R}^{2+}$ VS. componentes de $\mathrm{R}^{3+}$ individualmente, conclui-se que o $\mathrm{Al}^{\mathrm{N}}$ é o principal responsável por este tipo de substituição, mas o Ti também apresenta considerável participação.

Foram testados individualmente outros elementos. O gráfico $\mathrm{R}^{2+}$ vs. $\mathrm{Al}^{\mathrm{VI}}$ (Fig.4.4d) mostra boa correlação negativa, indicando a existência da substituição do $\mathrm{Al}^{\mathrm{V}}{ }^{\mathrm{n}}$ na posição octaédrica, por Fe $\mathrm{F}^{2+}$ e Mg. O Ti mostra boa correlação linear com o Mg (Fig.4.4e).

Os gráficos de $\mathrm{R}^{3+}$ vs. componentes individuais de $\mathrm{R}^{2+}$ mostram participação de $\mathrm{Mg}$ (Fig.4.6a e 4.6b) e $\mathrm{Fe}^{2+}$ (Fig.4.6c e 4.6d) neste tipo de substituição.

\footnotetext{
${ }^{3}$ Classificação de micas (Chevremont et al. 1988) com os campos representando as séries: 1a (aluminopotássica tipo Limousin); 1 b (alumino-potássica tipo Gueret); 2 (cálcio alcalina); 3a (sub alcalina ferro potássica) e $3 b$ (sub alcalina magnésio potássica)
} 

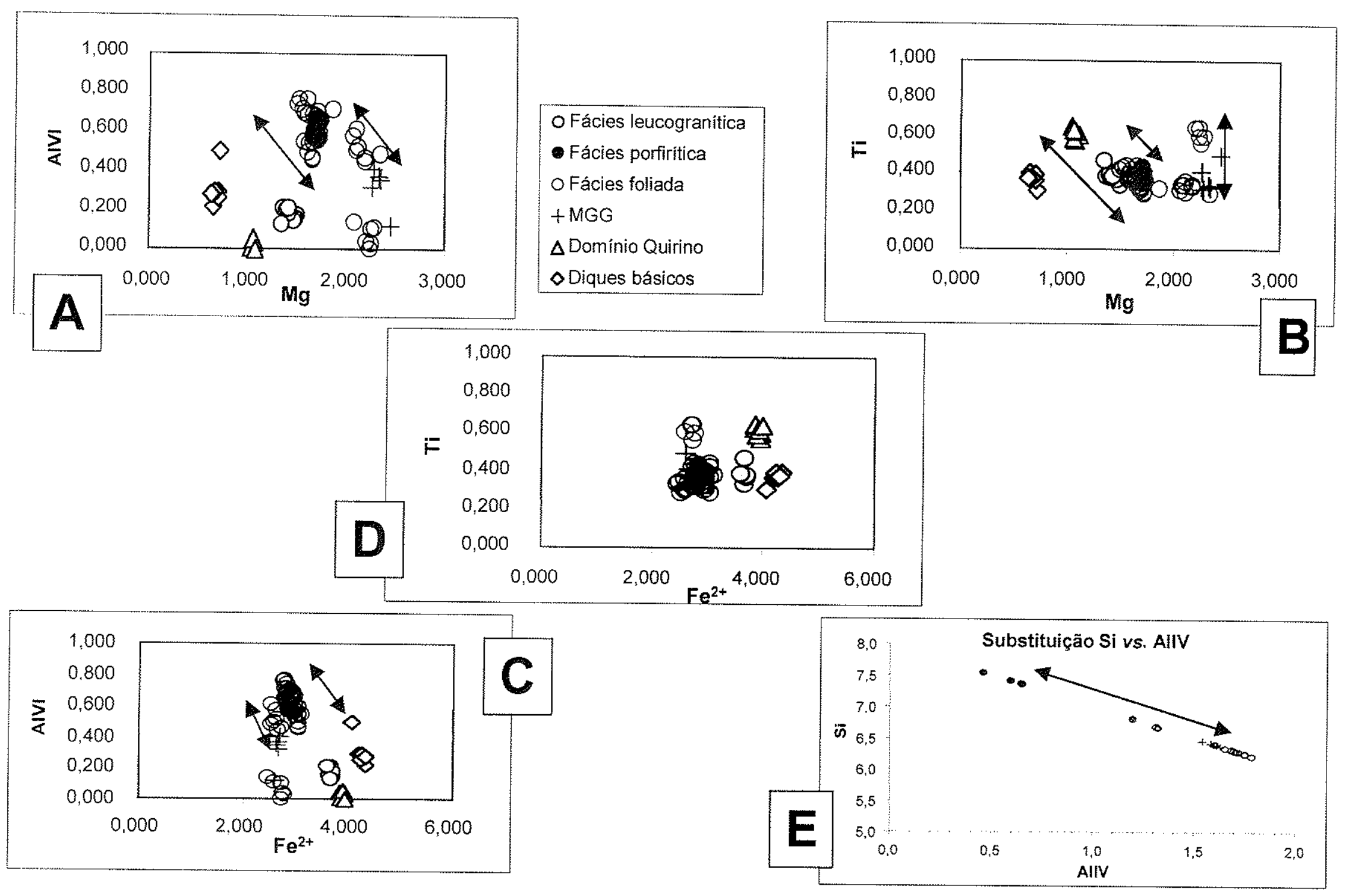

Figura 4.6. - Diagramas de substituições quimicas $R^{3}$ versus componentes de $R^{2}$ em biotitas. $A$ existência de dois trends composicionais distintos na fácies foliada, um com teor baixo em Mg e outro mais elevado (conforme setas), é compativel com as observacóes petrográficas (Capítulo 3).) nestas faciologias. A substituiçâo entre o alumínio e magnésio é muito comum nas rochas deformadas da fácies foliada. 
O gráfico Ti vs. Mg sugere a existência de substituição somente para o grupo das biotitas secundárias, sugerindo que este tipo de substituição ocorreu somente associado à fase de deformação (Fig. 4.6b).

A Si vs. Alv mostra excelente correlação linear negativa, como previamente era esperado, sugerindo a substituição no sítio tetraédrico (Fig.4.6e).

Outros tipos de substituições testadas para as biotitas da SIA, propostos por Hewitt \& Abrecht (1986), foram do tipo talco (Ca + Alv vs. K + Si) (Fig.4.7a) e clitonita (Si + SV vs. $\mathrm{K}+\mathrm{Al}^{\mathrm{IV}}$ ) (Fig.4.7b) onde este apresenta boa correlação linear negativa. A presença de correlação negativa evidencia a existência de substituição nas amostras estudadas, onde o Si está sendo substituido pelo $\mathrm{Al}^{\mathrm{IV}}$.

\subsection{Mica Branca}

A mica branca aparece mineral acessório com teores inferiores a $1 \%$ na fácies foliado do MGA e fácies leucogranítica.

Microscopicamente, a micas branca possui características semelhantes entre as diferentes faciologias, ocorrendo em todas elas como cristais intersticiais ou como produto de alteração de biotitas.

Foram analisadas um total de 3 amostras com mica branca, 1 amostra da fácies porfiritica (amostra EP) e 2 amostras da fácies foliada (amostra IP, LP) do MGA (Tab.4.7).

As amostras da EP possuem valores de $\mathrm{TiO}_{2}$ entre $0,1 \%$ a $0,7 \%$, muito semelhantes ao das amostras da LP $(0,2-0,7 \%$ ). Os teores em $\mathrm{FeO}$ (entre 2,3 a 2,5\%) e $\mathrm{MgO}$ (entre 0,8 a $1,3 \%$ ) da EP. são relativamente mais elevados do que a LP, com valores entre 1,4 a $2,5 \%$ e 0,8 a $1,5 \%$, respectivamente.

No diagrama triangular $\mathrm{TiO}_{2}-\mathrm{Fe}_{2} \mathrm{O}_{3}-\mathrm{MgO}$ (Fig.4.7c) a mica branca ocupa o campo inferior das moscovitas magmáticas, onde algumas amostras dispõem-se no campo das moscovitas secundárias e em faciologias diferentes. 


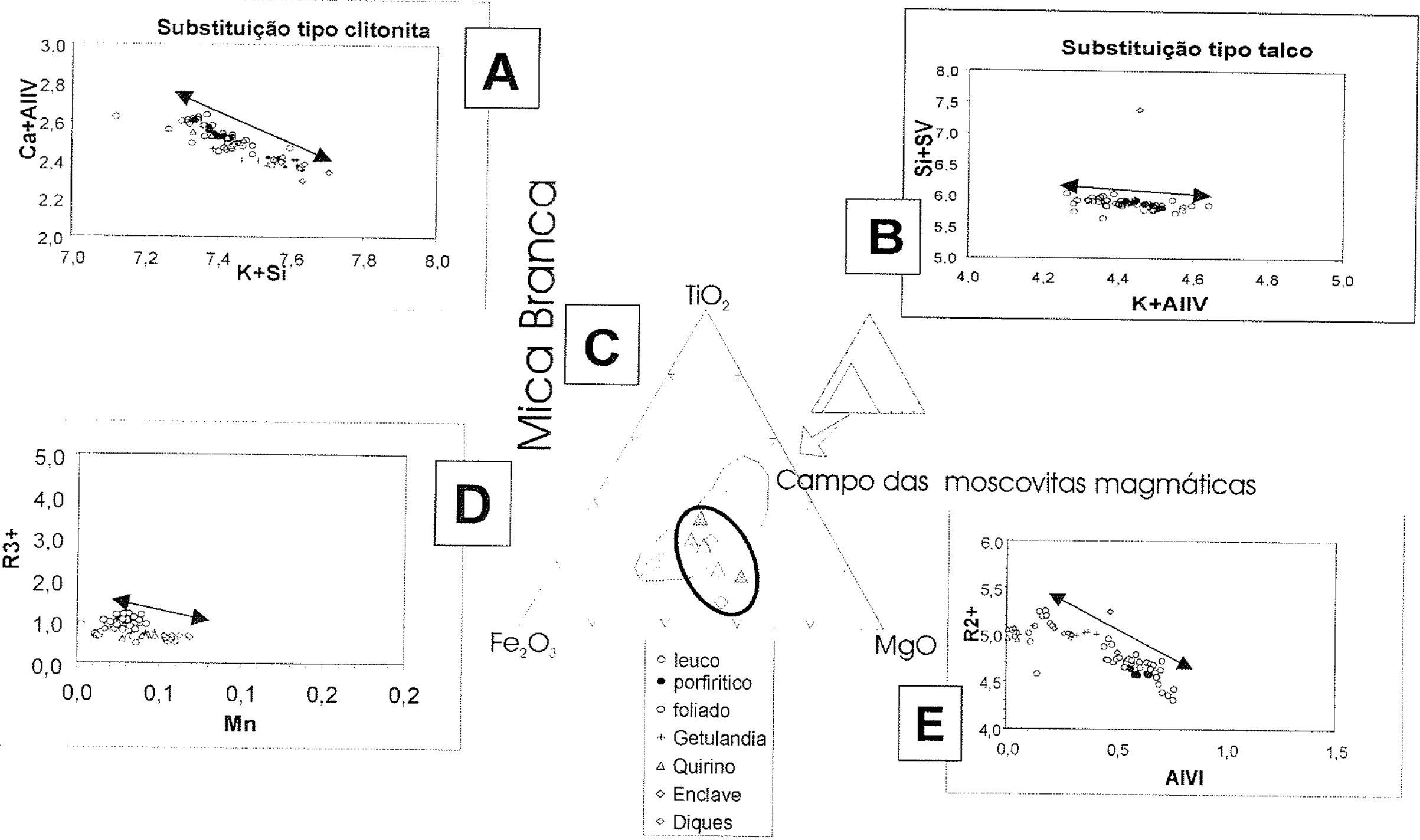

Fig. 4.7. Diagramas do tipo clitonita (Si + SV vs. $\left.K+A I^{\vee}\right)(A)$ e talco $\left(C a+A l^{\prime V}\right.$ vs. $\left.K+S i\right)(B)$ propostos por Hewitt \& Abrecht (1986), e de substituições adicionais entre $\mathrm{R}^{2+}$ versus componentes $\mathrm{Mn}$ e Alvl com boas correlações lineares negativas. O diagrama triangular TiO2 - Fe2O3 e MgO para mica branca no Domínio Quirino (próximo a ZCAP) e fácies foliada do MGG. 


\subsubsection{Anfibólio}

A fórmula estrutural dos anfibólios, calculada numa base anidra de 23 oxigênios (Deer et al. 1982), pode ser escrita genericamente como:

$\mathrm{A}_{0-2} \mathrm{~B}_{2} \mathrm{C}_{5} \mathrm{~T}_{8} \mathrm{O}_{22}(\mathrm{OH}, \mathrm{F})_{2}$ onde os sítios

$$
\begin{aligned}
& \mathrm{A}=\mathrm{Na}, \mathrm{K} ; \\
& \mathrm{B}=\mathrm{Na}, \mathrm{Ca}, \mathrm{Mg}, \mathrm{Fe}^{+2}(\mathrm{Mn}, \mathrm{Li}) ; \\
& \mathrm{C}=\mathrm{Mg}, \mathrm{Fe}^{+2}, \mathrm{Al}_{1} \mathrm{Fe}^{+3}(\mathrm{Mn}, \mathrm{Zn}, \mathrm{Cr}, \mathrm{Ti}, \mathrm{Li}) \mathrm{e} \\
& \mathrm{T}=\mathrm{Si}, \mathrm{Al} .
\end{aligned}
$$

Foram analisados 7 amostras com anfibólios das seguintes faciologias: quartzo monzonito associado ao MGA (1 amostra), enclave básico do MGA (1 amostra), MGG (1 amostra), Domínio Quirino (1 amostra) e diques básicos (3 amostras) (Tab.4.8).

Microscopicamente, os anfibólios estudados possuem características distintas nos dois maciços: no MGA apresentam pleocroísmo de azul-esverdeado a verde acinzentado, e no MGG de verde-claro a verde-escuro, e tamanhos variáveis entre 1,5 e $4 \mathrm{~mm}$.

Ocorrem como cristais submilimétricos, esparsos e diretamente associados às biotitas, minerais opacos, clorita e mica branca. Eventualmente pode estar associado à piroxênios nos diques básicos.

Segundo a classificação de Leake et al. (1997) (Fig.4.8a) Mg \# vs. Si os anfibólios analisados foram classificados em três grupos principais: o primeiro grupo é composto por Fe-tschermackita a tschermackita (amostras GP72-77 [Domínio Quirino] e CP68-71 [MGG]; O segundo grupo, por ferro a Mg-hornblenda (amostras JP109-114 [enclave máfico], 61, 111 e 111a [rochas básicas], e o terceiro, por harstingsita (amostra DP201203 [quartzo monzonito]). Apresentam entre 2,5 a $3,0 \%$ de $\mathrm{H}_{2} \mathrm{O}$, com o somatório do número de óxidos ficando em torno de $98 \%$.

\section{Substituiçöes}

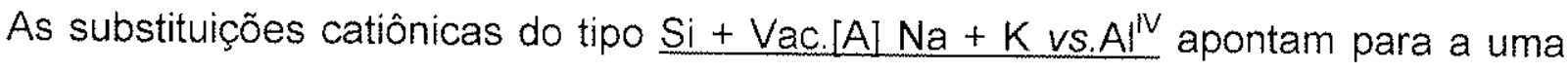
tendência linear inversa do termo pargasítica a actinolítica (Fig.4.8c). 


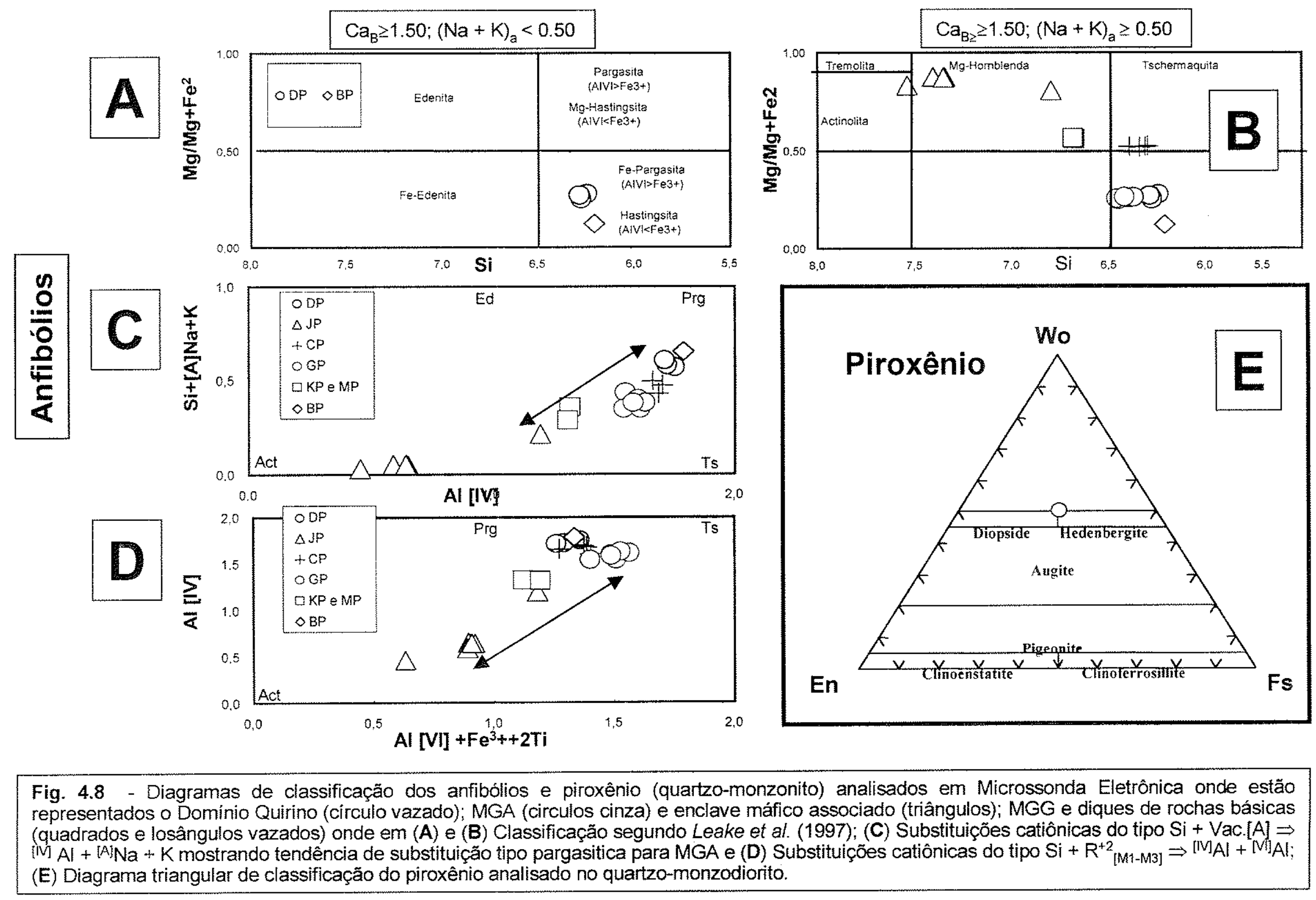


A substituição do tipo $\mathrm{Al}^{[\mathrm{V} V]}$ Vs. $\mathrm{Al}^{[\mathrm{VI}]}+\mathrm{Fe}^{3}+2 \mathrm{Ti}$ apenas para as fácies porfirítica e quartzo-monzonito, permite classificar a substituição destes anfibólios como do tipo pargasitica e tschermackítica (Fig.4.8d).

Cabe salientar, que o piroxênio que ocorre no enclave quartzo monzodiorito do MGA é classificado como hedenbergita (Fig.4.8e).

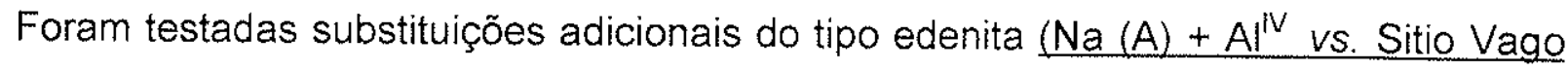
$\underline{A}+\mathrm{Si}$ (Fig.4.9a) e riebeckita $\mathrm{Na}$ vs. Sitio Vago $A+\mathrm{Ca}$ (Fig.4.9b), que sugerem uma substituição moderada entre $\mathrm{Na}$ e Ca no Sítio $\mathrm{A}$, e principaimente a substituição Si vs. $\mathrm{Al}^{\mathrm{lV}}$ (Fig.4.9c) com disposição linear negativa acentuada que indicam a ocorrência de trocas entre estes dois elementos.

De maneira geral, não ocorrem relações químicas entre anfibólios e biotitas.

\subsubsection{IImenita}

Os minerais opacos são representados por ilmenita (anedrais) no MGA, sendo associada com apatita, monazita (rica em Th) e mica branca, enquanto no MGG ocorre apenas magnetita (euédrica) associada com titanita e allanita.

\section{$\checkmark$ Discussão dos resultados}

Com base nos dados de química mineral apresentados neste capítulo, alguns aspectos pode ser ressaltados:

Os plagioclásios apresentam composições mais cálcicas nos megacristais e empobrecidos em cálcio na matriz reafirmando o caráter de cristalização fracionada para a evolução dos mesmos. Salienta-se a maior abundância deste mineral no MGG vinculado ao seu caráter magmático mais evoluído, quando comparado ao MGA.

A ocorrência de ortoclásio como megacristal, relacionado à cristalização magmática precoce, e de microclina intersticial na matriz em estágio tardio (MGA), pode ser relacionada à deformação em estado sólido associada à movimentação da ZCAP após completa cristalização do magma granítico. 

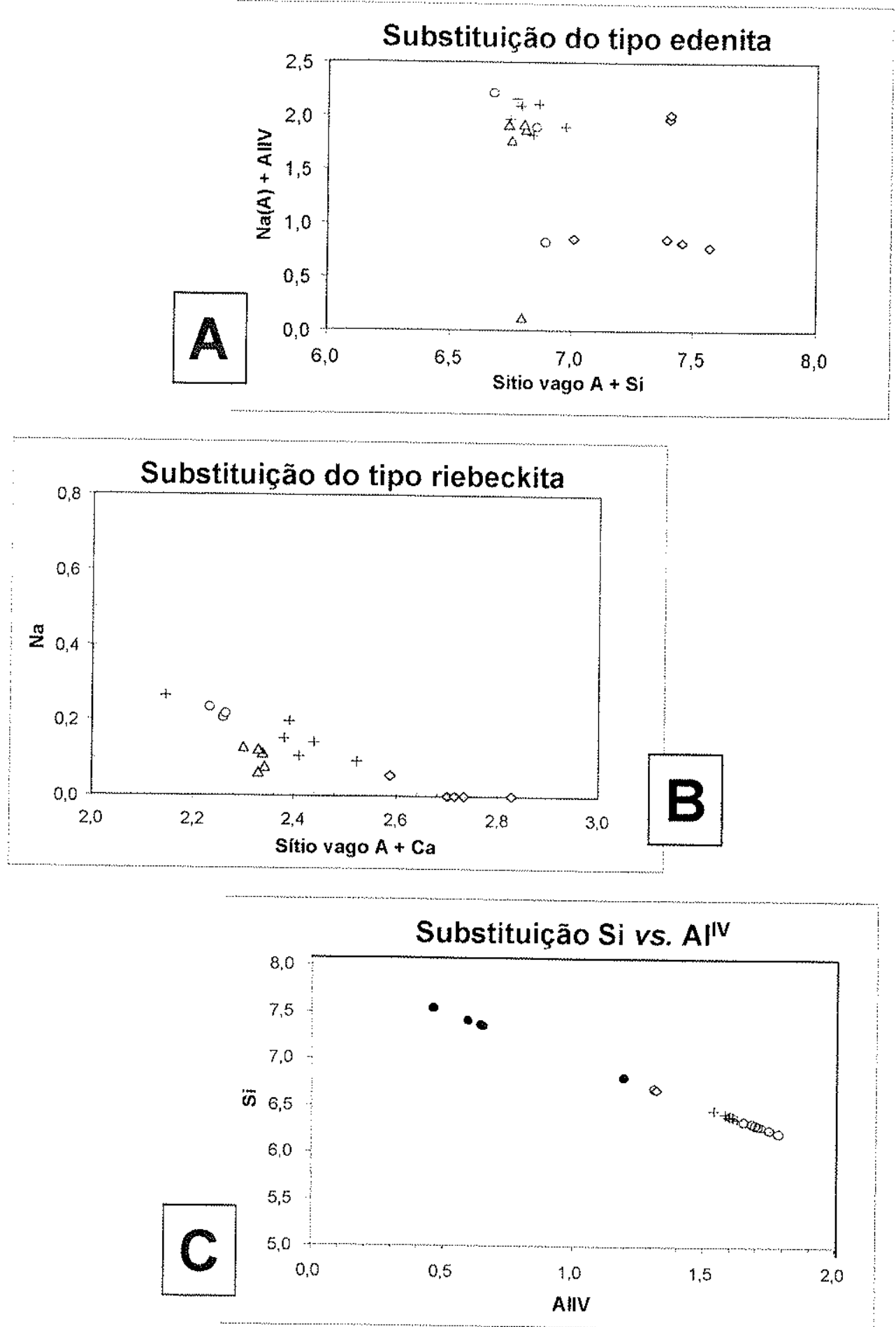

Fig.4.9. Diagramas de substituições em anfibólios do tipo edenita $\left(\mathrm{Na}(\mathrm{A})+\mathrm{Al}^{\mathrm{N}}\right.$ vs. Sitio Vago $\left.\mathrm{A}+\mathrm{Si}\right)(\mathrm{A})$ e riebeckita (Na vs. Sitio Vago $A+C a)(B)$, e substituição Si vs. Alv $(C)$. 
Os dados petrográficos apresentam dois grupos distintos de biotitas, confirmado pelos dados obtidos na química mineral. A presença de deformação em estado sólido com nas bordas do MGA sugere o condicionamento de um dos grupos de biotitas ao metamorfismo regional.

Os anfibólios dos MGA e MGG apresentam parâmetros químicos semelhantes. As pequenas variações composicionais apresentadas estão relacionadas aos diferentes estágios evolutivos dos maciços.

Os dados petrográficos mostram a natureza secundária da mica branca, aspecto este que pode estar associado à presença de uma fase fluída tardia que promoveu a moscovitização das biotitas.

Ressalta-se a presença de ilmenita associada com apatitas e mica branca no MGA, denotam um caráter mais peraluminoso a este maciço, enquanto a ocorrência de titanita, allanita e magnetita no MGG refletem num caráter metaluminoso. 


\section{Geoquimica}

4.2 Caracterizaçäo geoquímica dos Granitóides da regiäo de Arrozal 88 Introduçäo. .88

4.2.1. Maciço Granitico Arrozal (MGA) .90

4.2.1.1 Fảcies porfiritica e quartzo monzonito leucocrático 90

4.2.1.2. Fácies foliada. .93

4.2.2. Maciço Granitico Getulândia (MGG). 99

Discussão dos resultados. 100 


\subsection{Caracterização Geoquímica dos Granitóides da região de Arrozal}

\section{Introdução}

Foram selecionadas 27 amostras para análise de rocha total, representativas das principais unidades que compõem a Suíte Intrusiva Arrozal (SIA). Esta suite engloba os Maciços Graníticos Arrozal (MGA), Getulândia (MGG) e Maciço Fortaleza (MGF), cuja composição dominante situa-se entre granítica e granodiorítica.

O Maciço Granítico Arrozal, objeto deste trabalho, é constituído de 3 faciologias principais: fácies porfirítica (central), fácies foliada (de borda) e fácies leucogranítica. Destas faciologias, há um predomínio da fácies foliada, aparecendo a fácies leucogranítica como subordinada. Cabe salientar que, na fácies foliada, associam-se porções mais deformadas, com a rocha assumindo muitas vezes em campo aspecto gnáissico e protomilonítico. Contudo, muitas destas amostras em lâmina delgada não exibem deformação em estado sólido (Fig.4.10).

Foram também analisadas amostras de maciços similares (MGG, 2 amostras), bem como da rocha encaixante (Domínio Quirino, 4 amostras) e de rochas básicas (diques e sills, 4 amostras), visando discutir a origem do magmatismo granitico. As amostras do MGG classificam-se como monzogranito, as do Domínio Quirino, como granito (monzo e 


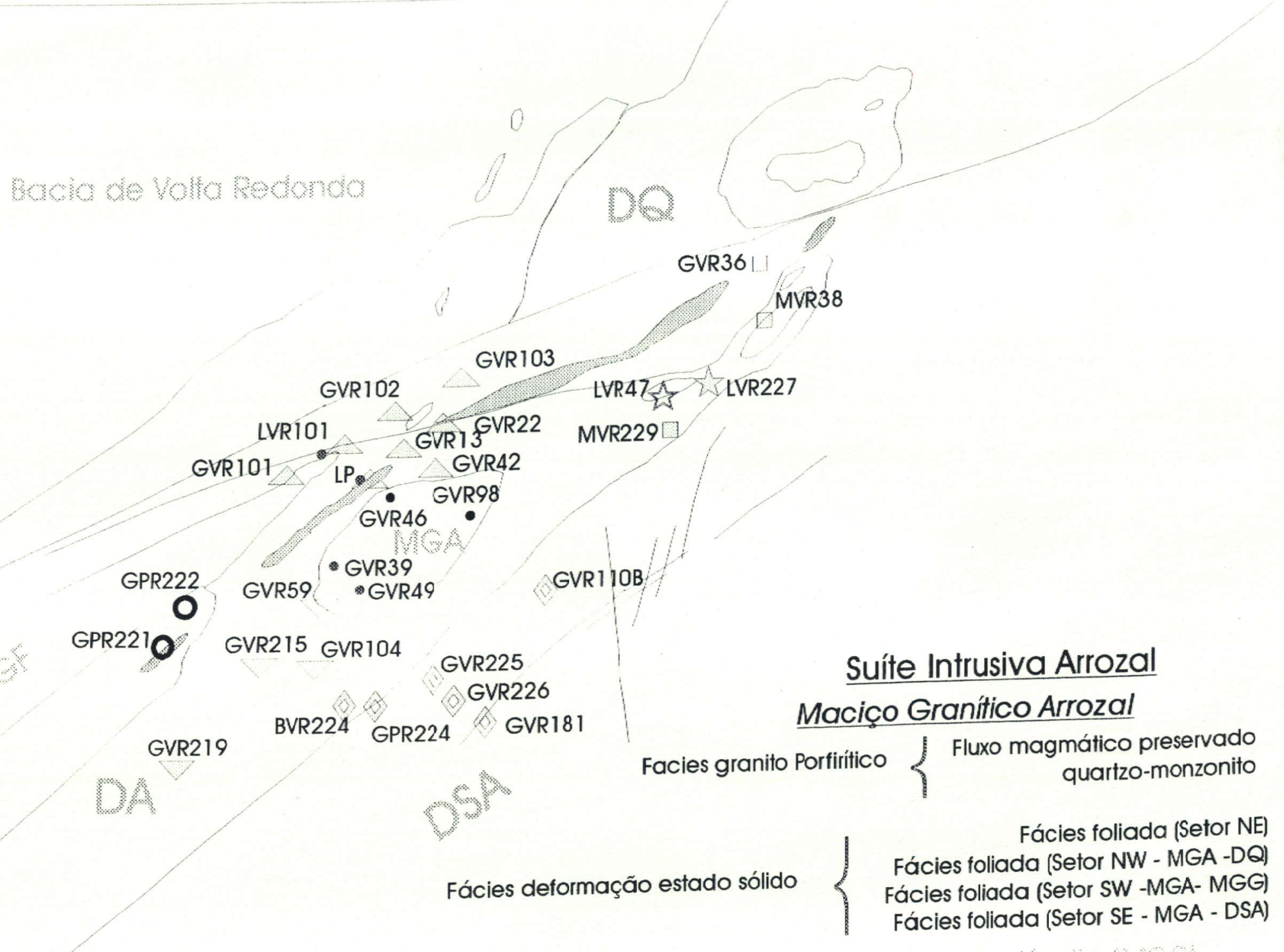

Figura 4.10. Localização das amostras dos estudos de litogeoquímica da Suite Intrusiva Arrozal, distribuidas em três setores principais : Maciço Granítico Arrozal (MGA); Maciço Granítico Getulândia (MGG) e setor deformado (tácies foliada) das bordas destes maciços (mapa simplificado na escala 1:330.000) 
sieno), quartzo monzonito e quartzo sienito, enquanto os diques e sills, como diorito e quartzo diorito.

Estas faciologias classificam-se no diagrama QAP de Streckeisen (1976) como monzogranito a granodiorito (fácies porfirítica, 4 amostras), monzogranito (fácies foliada, 20 amostras) e quartzo monzonito a monzogranito (fácies leucogranítica, 2 amostras) (Fig. 4.14a). Foram também analisadas 2 amostras de enclaves do MGA, cuja composição situa-se no campo do quartzo monzodiorito.

$\mathrm{Na}$ maioria dos diagramas apresentados utilizou-se a $\mathrm{SiO}_{2}$ como índice de diferenciação. Embora tenham sido confeccionados vários diagramas, onde foram testados outros elementos (maiores e traços), optou-se aqui por apresentar os diagramas que são efetivamente importantes na discussão sobre a cristalização dos minerais. Além disso, foi efetuado um tratamento geoquímico individualizado entre as fácies porfirítica e foliada do MGA, visando desta forma avaliar possiveis modificações químicas decorrentes da deformação.

\subsection{1 - Maciço Granítico Arrozal (MGA)}

\subsubsection{Fácies porfiritica e quatzo-monzonito leucocrático associado}

A fácies porfirítica, caracterizada pelo predomínio de estruturas magmáticas, inclui quatro amostras (GVR49, GVR39, GVR46, e GVR98) oriundas da porção central do maciço, de composição dominante é monzogranítica, e duas amostras da fácies quartzomonzonito leucocrático (LVR47 e LVR227), classificadas como quartzo monzonito a monzogranito.

O comportamento geoquímico (elementos maiores e traços) destas amostras, com base nos em diagramas de variação e multi-elementos, são discutidos a seguir.

Os teores em $\mathrm{SiO}_{2}$ das amostras de ambas as faciologias variam entre 63.2 a $69.3 \%$, com valores de $\mathrm{K}_{2} \mathrm{O}$ (\% em peso) entre 3,1 e $4,6 \%$ e razão $\mathrm{K}_{2} \mathrm{O} / \mathrm{Na}_{2} \mathrm{O}$ entre 0,9 e 1,7 (Tab.4.9). $\mathrm{Na}$ comparação entre as duas faciologias, nota-se que a fácies porfirítica apresenta valores mais elevados em $\mathrm{SiO}_{2}$ e razão $\mathrm{K}_{2} \mathrm{O} / \mathrm{Na}_{2} \mathrm{O}$ mais baixa, sugerindo assim tratar-se de uma faciologia mais evoluída, o que também é sugerido pela sua composição mineralógica.

O conteúdo em elementos traços destas faciologias são elevados em $\mathrm{Rb}$ (136 a 220 ppm), Ba (2005 a 593 ppm), Zr (899 a 211 ppm) e Nb (16 a 38 ppm); e moderados em $\mathrm{Sr}$ 
(787 a $199 \mathrm{ppm}$ ), Tab.4.9). A fácies porfirítica exibe teores mais elevados em $\mathrm{Rb}$, mais baixos em $\mathrm{K}_{2} \mathrm{O}, \mathrm{Ba}, \mathrm{Zr}$ e $\mathrm{Sr}$, e equivalentes em $\mathrm{Nb}$, confirmando deste modo o seu caráter mais evoluido.

Estes valores em Rb são compativeis com o intervalo de valores dos granitos félsicos não fracionados (entre 200 e 250 ppm, 64 amostras do tipo-l e 119 do tipo-S) do cinturão Lachlan na Austrália (Chappell \& White 1992).

A predomínio de plagioclásio em relação ao feldspato potássico na fácies leucogranítica reflete-se por razões $\mathrm{Rb} / \mathrm{Sr}<0.5$, enquanto a fácies porfirítica (com megacristais de feldspato potássico + biotita) apresenta razões $\mathrm{Rb} / \mathrm{Sr}$ superiores a 0.7 , com máximo de 1.1 .

$O$ índice de saturação em alumina (AVNK) do conjunto de amostras estudadas é próximo a 1,0 (Fig.4.11a), com um grupo delas situando-se no campo metaluminoso (fácies leucogranítica, A/CNK $\sim 0,9$ ) e outro no campo marginalmente peraluminoso (fácies porfirítica, 1,1<A/CNK < 1,2), segundo o diagrama de Maniar \& Piccoli (1989). Os primeiros valores situam-se no intervalo de A/CNK (entre 0,9 e 1,1) definido por Chappell \& White (1992) para os granitos tipo-l do cinturão Lachlan na Austrália, enquanto os últimos situam-se no intervalo de superposição dos granitos tipo-I e $S$ (entre 1,1 e 1,4).

A relação FeOt / $\mathrm{FeOt}+\mathrm{MgO}$ da fácies leucogranítica varia de 0,73 a 0,56 , sendo estes valores explicados pela presença de minerais ferro-magnesianos contendo assembléias com proporções variáveis de piroxênio (hedenbergitas encontradas como relíctos) + Fe-hornblenda + biotita. Na fácies porfiritica, esta relação é mais ou menos constante, com valores ao redor de 0,63 , os quais podem ser explicados pela presença de minerais máficos como Fe-hornblenda + biotita (Fig.4.12c).

No diagrama AFM, de Irvigne \& Baragar (1971), as amostras estudadas ocupam o campo das rochas cálcio-alcalinas (Fig.4.11b). $\mathrm{O}$ teor em $\mathrm{K}_{2} \mathrm{O}$ situa-se no campo das séries magmáticas alto $\mathrm{K}$, segundo o diagrama de Le Maître (1985).

O conteúdo elevado em elementos traços ( $\mathrm{Rb}, \mathrm{Ba}, \mathrm{Zr}$ e $\mathrm{Nb}$ ) reafirma o caráter potássico destas rochas (Fig.4.11d-h). Nota-se que estes elementos em diagramas Harker (Fig.4.11) exibem em geral uma correlação negativa, a qual é menos evidente para - Sr. Esta correlação negativa dos elementos pode ser explicada como resultado da acumulação de plagioclásio e feldspato alcalino acompanhados de zircão \pm ilmenita na 

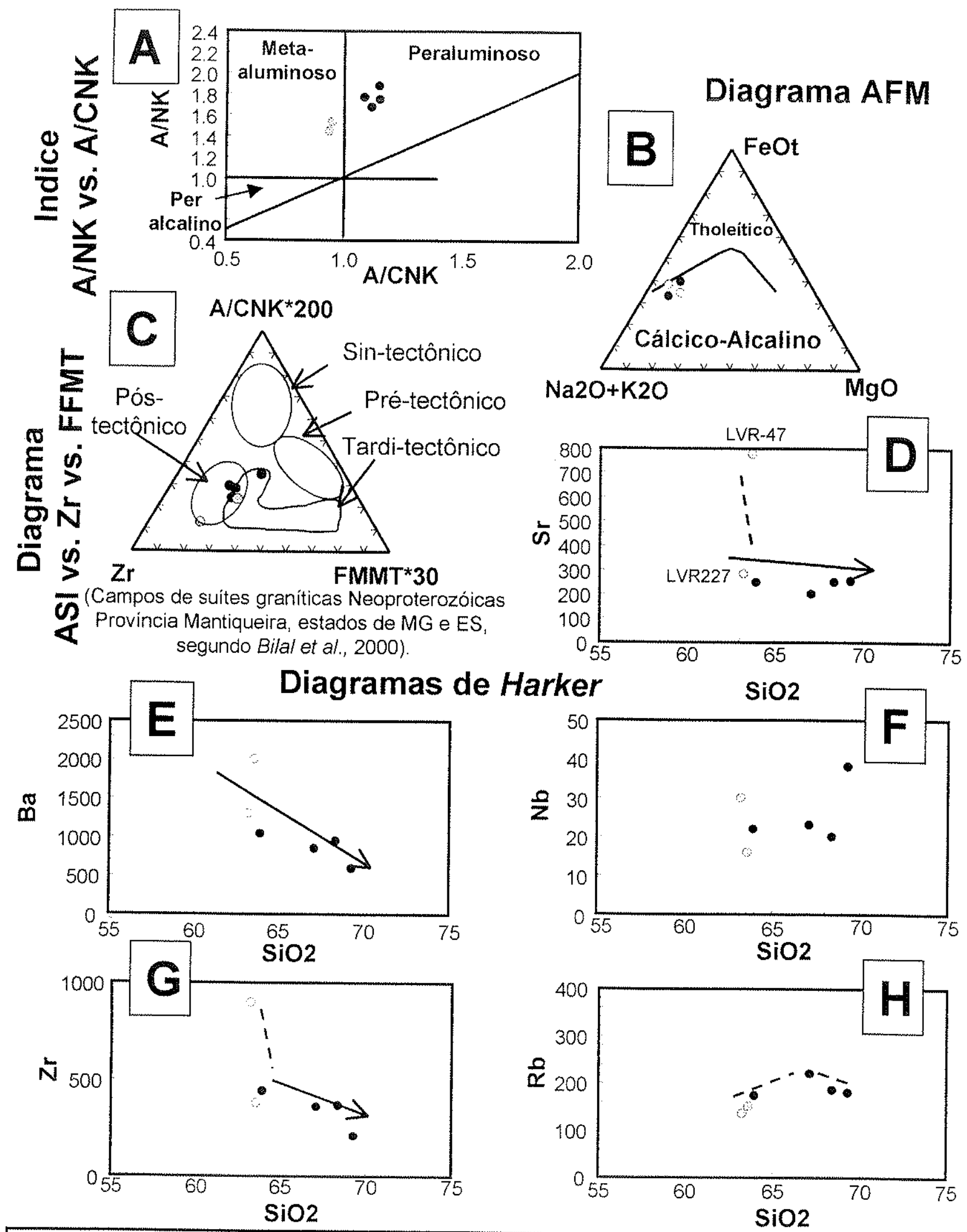

Figura 4.11 - Diagramas geoquímicos para a fácies porfiritica (circulo negro) e quartzomonzonito (circulo cinza) associado: A - Classificação segundo o indice de saturação em alumina; B Classificação no diagrama AFM ; C - Posição no diagrama $A / C N N^{*} 200$ vs. Zr. vs. FMMT*30 comparados com os dados obtidos por Bilal et al.(2000); e D - Diagramas de Harker para Sr, Ba, $\mathrm{Nb}$, Zr e Rb (tendências assinaladas por flechas) 
fácies leucogranitica (refletidos pelos altos picos em Sr, Ba, Zr, das amostras LVR47 e LVR227, Tab.4.9 e Fig.4.11).

O efeito cumulativo do plagioclásio nesta faciologia é mais efetivo na primeira amostra (LVR 47) do que na segunda (LVR 227), conforme pode ser observado nos teores mais elevados em $\mathrm{Ca}(3,5 \%$, contra 3,2\%), Sr (787 ppm, contra 283 ppm), Ba (2005 ppm, contra $1306 \mathrm{ppm}$ ) e $\mathrm{Al}_{2} \mathrm{O}_{3}(16,0 \%$, contra $15,5 \%)$, e mais baixos em $\mathrm{K}_{2} \mathrm{O}(4,2 \%$, contra $4,6 \%)$. O Rb, ao contrário destes elementos, apresenta uma leve correlação positiva.

Nas amostras da fácies porfirítica parece ter havido uma participação mais importante da biotita, conforme sugerido pela tendência levemente positiva do Rb durante a diferenciação e sendo isto desvinculado do comportamento observado para $\circ \mathrm{Ba}$. A mudança de comportamento no $\mathrm{Rb}$ com $\mathrm{SiO}_{2}$ ao redor de $67 \%$ deve traduzir uma cristalização mais efetiva do feldspato potássico e biotita a partir deste momento (Fig. 4.11h). Isto também é observado na curva de comportamento do $\mathrm{K}_{2} \mathrm{O}$ (Fig.4.12e).

No diagrama triangular $\mathrm{Zr} \times \mathrm{ACNK}^{\star} 200 \times \mathrm{FMMT}^{\star} 30$, utilizado por Bilal et al (2000) para caracterização tectônica das suites graníticas neoproterozóicas da Província Mantiqueira nos estados de Minas Gerais e Espirito Santo, as amostras de ambas as faciologias ocupam o campo dos granitos tardi e pós-tectônicos (Fig. 4.11c).

Nos diagramas clássicos de discriminação de ambientes tectônicos, as amostras destas faciologias distribuem-se nos campos de granitos pré- a sin-colisionais (Batchelor \& Bowden 1985), e entre arco vulcânico a intraplaca (Pearce et al. 1984).

\subsubsection{Fácies foliada}

O mapa da Figura 4.10 mostra a distribuição dos pontos analisados desta faciologia e a divisão em quatro setores, denominados informalmente de NE, NW, SW e SE. Esta subdivisão foi efetuada com o objetivo de avaliar possiveis influências das rochas encaixantes no quimismo do MGA (Tab.4.9). Deste modo, os setores acima são constituídos da seguinte maneira: 


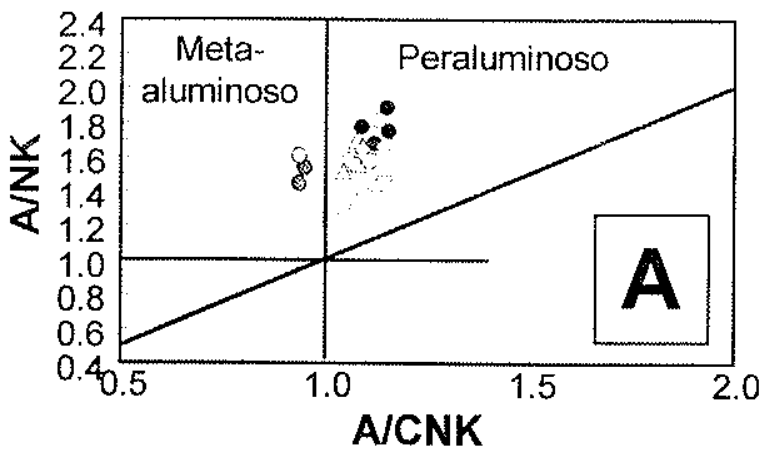

Macico Granítico Arrozal Fácies porfirítica

- Arrozal-Fácies porfirítica

-Arrozal - quartzo-monzonito
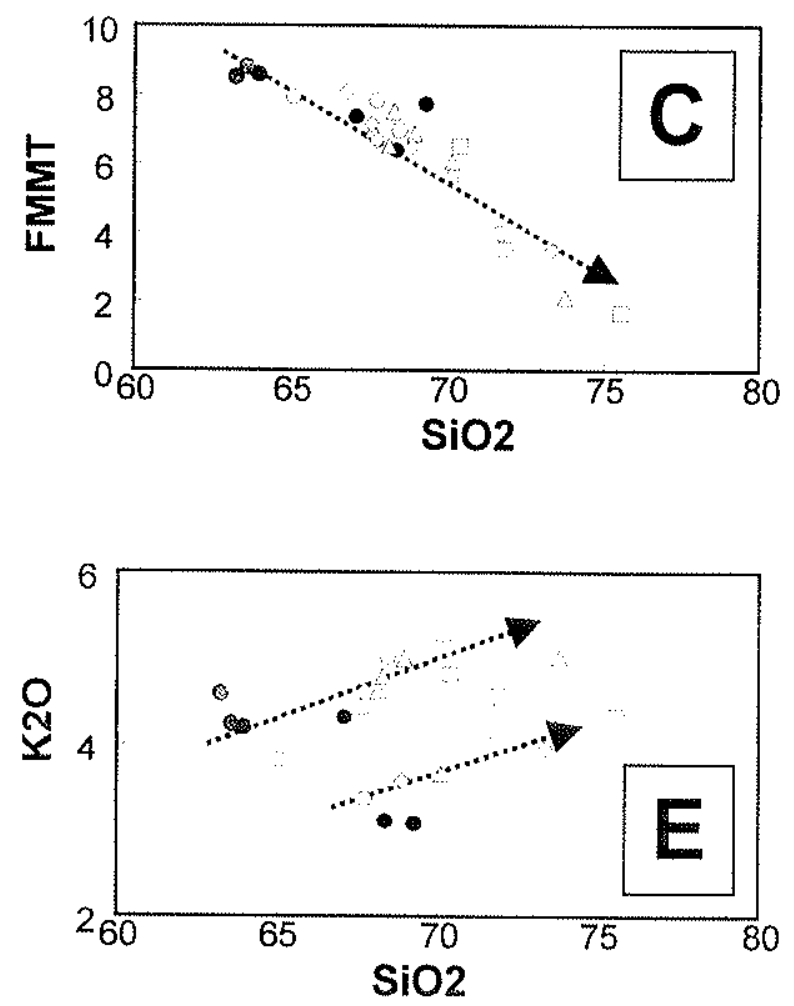

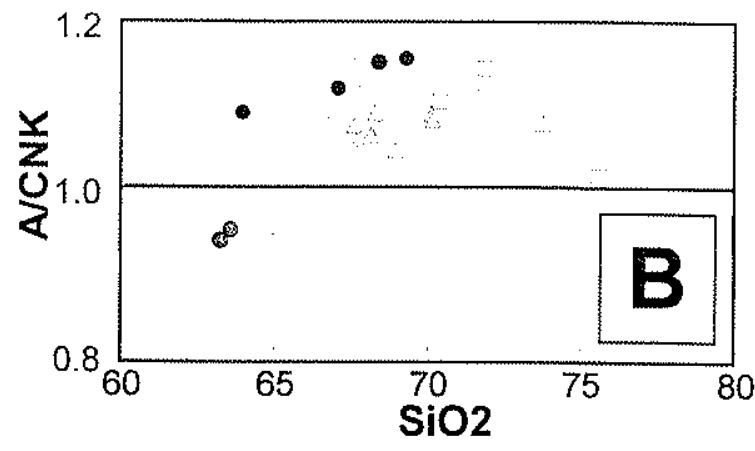

Macico Granítico Arrozal Fácies foliada

Arrozal - Fácies foliada NE Arrozal - Fácies foliada NW

Fácies foliada entre MGA e MGG

Fácies foliada entre MGA e DSA
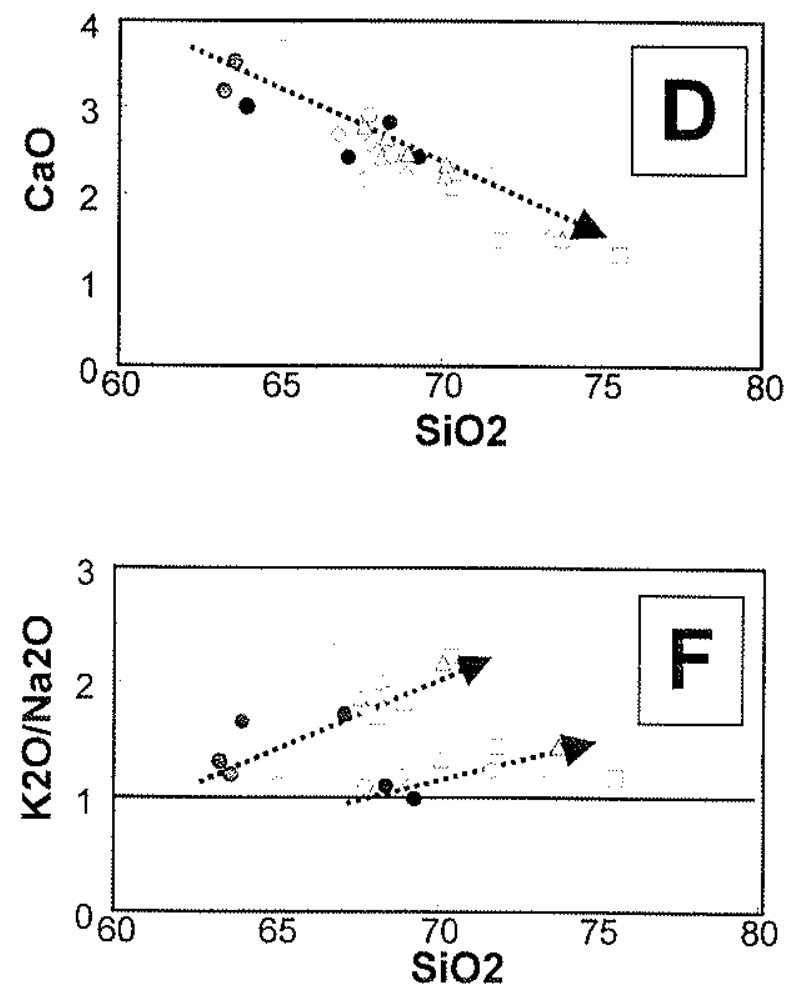

Figura 4.12 - Variação composicional das rochas da fácies foliada comparadas com aquelas da fácies porfiritica. Notar apresentação dos dados por áreas de amostragem. Destacamse a passagem de rochas meta luminosas, para peraluminosas, mais abundantes. No entanto, o parâmetro A/CNK é relativamente pouco variável. Nos diagramas de Harker destaca-se a correlação negativa de FMMT (Fe2O3t + $\mathrm{MnO}+\mathrm{MgO}+\mathrm{TiO} 2$ ) e do $\mathrm{CaO}$. Quanto aos alcalinos nota-se duas tendências gerais de correlação positiva de $\mathrm{K} 2 \mathrm{O}$ e $\mathrm{K} 2 \mathrm{O} / \mathrm{Na} 2 \mathrm{O}$ são assinaladas. 
1. Setor NE - duas amostras de granitóides intensamente deformados (GVR36 e MVR 38), evoluidos $\left(\mathrm{SiO}_{2} 72\right.$ a 76\%), e uma amostra da fácies foliada (MVR 229, com 70,4 $\%$ de $\left.\mathrm{SiO}_{2}\right)$;

2. Setor NW (entre a fácies porfirítica e o Domínio Quirino) - inclui um grupo de oito amostras (GVR 22, GVR 42, GVR13, GVR 102, MVR 27, LVR 101, GVR 101 e GVR 103). Estas rochas gradam lateralmente para a fácies porfirítica. Seus teores em $\mathrm{SiO}_{2}$ variam de 62,9 a $73,8 \%$.

3. Setor SW (entre a fácies porfiritica e o MGG) - as de quatro amostras deste setor (GVR219, GVR104, GVR59, GVR215), possuem teores em $\mathrm{SiO}_{2}$ entre 65,1 a $71,7 \%$;

4. Setor SE (entre a fácies porfirítica e o Domínio Serra das Araras) - este setor, mais heterogêneo, predominam "protomilonitos" intercalados com rochas granitíticas e básicas. Foram analisadas cinco amostras desta faciologia (GVR224, GVR225, GVR226, GVR181, GVR110B), cujos teores em $\mathrm{SiO}_{2}$ variam entre 66.8 a $73,4 \%$.

A fácies foliada, litologicamente mais heterogênea do que as faciologias anteriores, classificam-se no diagrama QAP de Streckeisen (1976) como granodiorito a monzogranito (Fig.4.14)

O comportamento geoquímico para um conjunto de diagramas selecionados está representado na Figura 4.12. As tendências observadas nestes diagramas podem ser sumarizadas da seguinte maneira:

$\checkmark$ A manutenção do índice de saturação em alumínio (AVNK) em torno de 1,1 (entre 1,0 e 1,2). No diagrama de Maniar \& Picolli (1989) observa-se que as amostras do granito foliado superpõem-se em grande parte com as amostras da fácies porfirítica, caracterizando igualmente como magmatismo marginalmente peraluminoso.

$\checkmark$ Os diagramas de variação de $\mathrm{CaO}$ e o índice FMMT $\left(\mathrm{Fe}_{2} \mathrm{O}_{3} \mathrm{t}+\mathrm{MnO}+\mathrm{MgO}+\right.$ $\mathrm{TiO}_{2}$ ), em função da $\mathrm{SiO}_{2}$, apresentam correlação negativa, sugerindo que o granito foliado guarda evidências de processos de diferenciação magmática da mesma forma como foi identificada para a fácies porfirítica.

$\checkmark \mathrm{O} \mathrm{K} \mathrm{K}_{2} \mathrm{O}$, apesar de uma relativa dispersão, apresenta tendência geral de correlação positiva com a $\mathrm{SiO}_{2}$, traduzindo o papel importante do feldspato alcalino no processo de diferenciação magmática. Observa-se ainda que esta tendência é marcada por uma dispersão maior de dados ao longo de duas linhas paralelas de aumento de $\mathrm{K}_{2} \mathrm{O}$, 
que se repetem de maneira similar como aumento da razão $\mathrm{K}_{2} \mathrm{O} / \mathrm{Na}_{2} \mathrm{O}$. Isto pode ser explicado de duas formas: a) presença em maior ou menor proporção de megacristais de feldspato alcalino; e b) efeito da sobreposição do processo de deformação milonítica que tende a produzir rochas mais enriquecidas em $\mathrm{SiO}_{2}$ e, portanto, causar um efeito de diluição dos álcalis.

As tendências gerais exibidas pelos elementos maiores se repetem para os elementos traços selecionados. Na Figura 4.13 foram construídos os diagramas de Harker para $\mathrm{Ba}, \mathrm{Sr}, \mathrm{Zr}$ e $\mathrm{Rb}$. Estes diagramas confirmam a tendência de evolução magmática observada em ambas as faciologias. Esta evolução é compatível com a diminuição progressiva de $\mathrm{Ba}, \mathrm{Sr}$ e $\mathrm{Zr}$, acompanhada por um ligeiro aumento do $\mathrm{Rb}$. Isto é confirmado pela correlação positiva apresentada pelo diagrama de $\mathrm{Zr}$ vs. $\mathrm{Ba}$, denotando a maior participação de zircão e feldspatos desde os termos menos evoluídos $\left(\sim 63 \% \mathrm{em} \mathrm{SiO}_{2}\right)$ até os mais evoluidos $\left(\sim 73 \%\right.$ em $\left.\mathrm{SiO}_{2}\right)$.

$\checkmark$ A comparação entre os setores evidencia comportamento similar para o conjunto de elementos nos diferentes diagramas selecionados, com exceção das amostras do setor SW, que apresentam acentuada dispersão. O comportamento anômalo da amostra GPR 215, com elevados teores em Ba (1822 ppm.), Sr (486 ppm.) e relativamente em $\mathrm{Al}_{2} \mathrm{O}_{3}$, baixos em $\mathrm{Rb}$ (93 ppm.) e na razão $\mathrm{Rb} / \mathrm{Sr}(0,2$ contra 0,5 a 1,2 , nas demais amostras deste setor), sugere interação com fase fluida, que teria promovido a ou cristalização de feldspato alcalino (microclínio) na matriz de MGG ou segunda geração de biotita (metamórfica) com características composicionais mais magnesianas.

$\checkmark \quad$ O comportamento do granito foliado em relação aos parâmetros de A/CNK, FMMT e o teor em $\mathrm{Zr}$ (Fig.4.13f) permanece semelhante ao que foi observado nas amostras da fácies porfirítica (comparar com a Fig.4.11c), com as amostras ocupando igualmente o campo de rochas tardi a pós-tectônicas da classificação dos granitóides Neoproterozóicos dos estados do Espírito Santo e Minas Gerais (Bilal et al. 2000).

O conjunto de amostras desta faciologia distribui-se nos mesmos campos dos diagramas discriminantes das fácies porfirítica e leucogranítica.

Os granitóides pertencentes a SIA, normalizados segundo os granitos de dorsais oceânicas (Pearce et al 1984), apresentam valores de BaORG $>11$ a 40 , NbORG $>1,6$ a 3,3 e ZroRg $>0,6$ a 2,6 , que são superiores aos dos granitóides peraluminosos do cinturão 

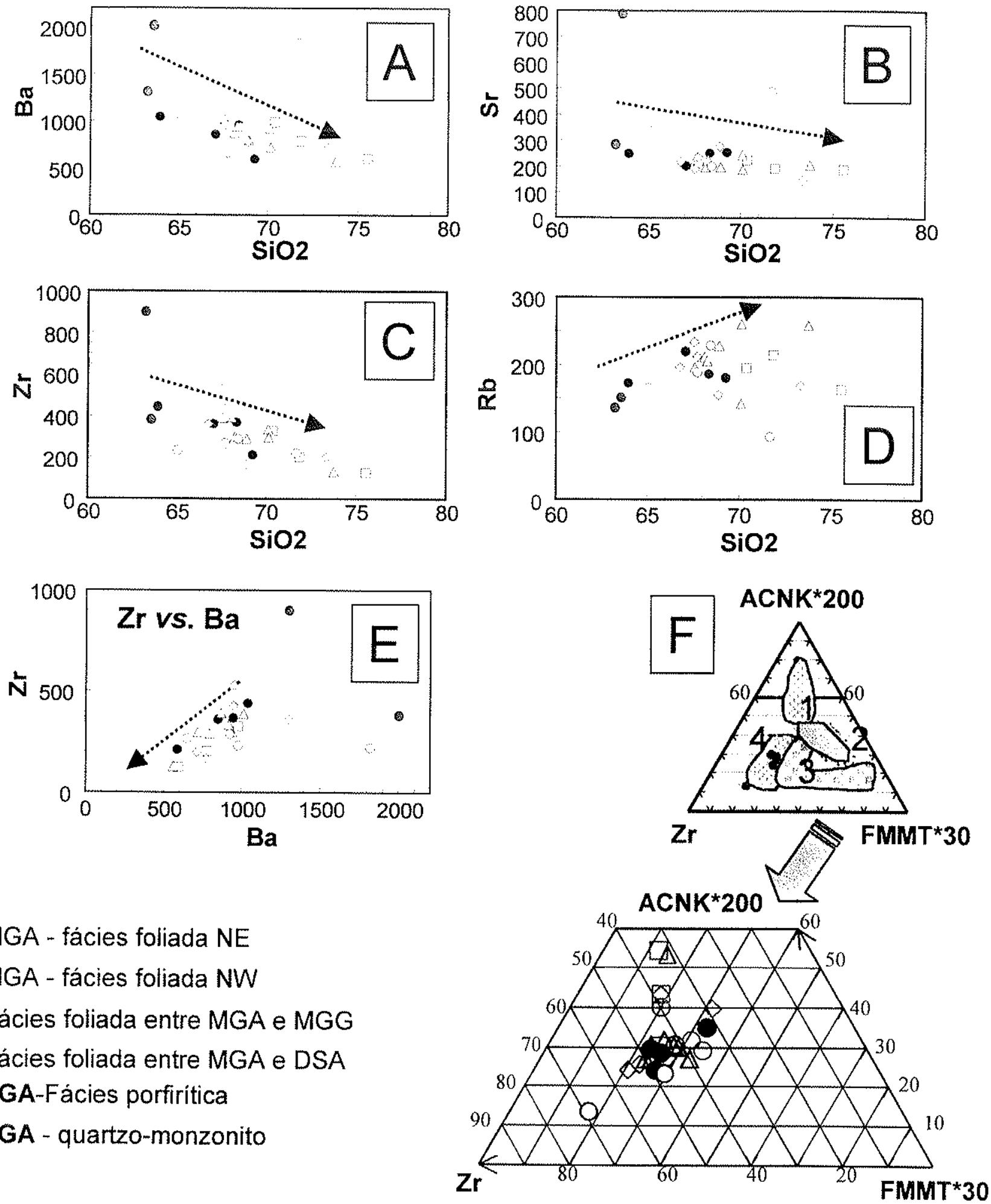

MGA - fácies foliada NE

MGA - fácies foliada NW

Fácies foliada entre MGA e MGG

Fácies foliada entre MGA e DSA

- MGA-Fácies porfiritica

- MGA - quartzo-monzonito

FMMT*30

Figura 4.13 - Diagramas de Harker para Ba (A), $\operatorname{Sr}(\mathrm{B}), \mathrm{Zr}$ (C). $\mathrm{Rb}$ (D) e $\mathrm{Zr}$ com Ba(E) da fácies foliada em comparação com a fáceis porfiritica central e quartzo-monzonito associado. Notar a correlação negativa do $\mathrm{Ba}, \mathrm{Sr}$ e $\mathrm{Zr}$, e ligeiramente positiva do $\mathrm{Rb}$. O diagrama $\mathrm{Zr}$ vs. Ba sugere que o conjunto de amostras da fácies foliada segue a mesma tendência de evolução magmática. Os campos delimitados no diagrama triangular $A_{C N K}{ }^{\star} 200$ vs. Zr vs. FMMT*30 (F) foram extraídos de Billal et al. (2000), e representam respectivamente granitóides sin-tectônicos (1), pré-tectônicos (2), tardi-tectônicos (3) e pós-tectônicos (4). Este diagrama permite considerar que o conjunto de dados da fácies foliada está quimicamente relacionada ao processo de deformação superposto à fase magmática da porção central do MGA. 

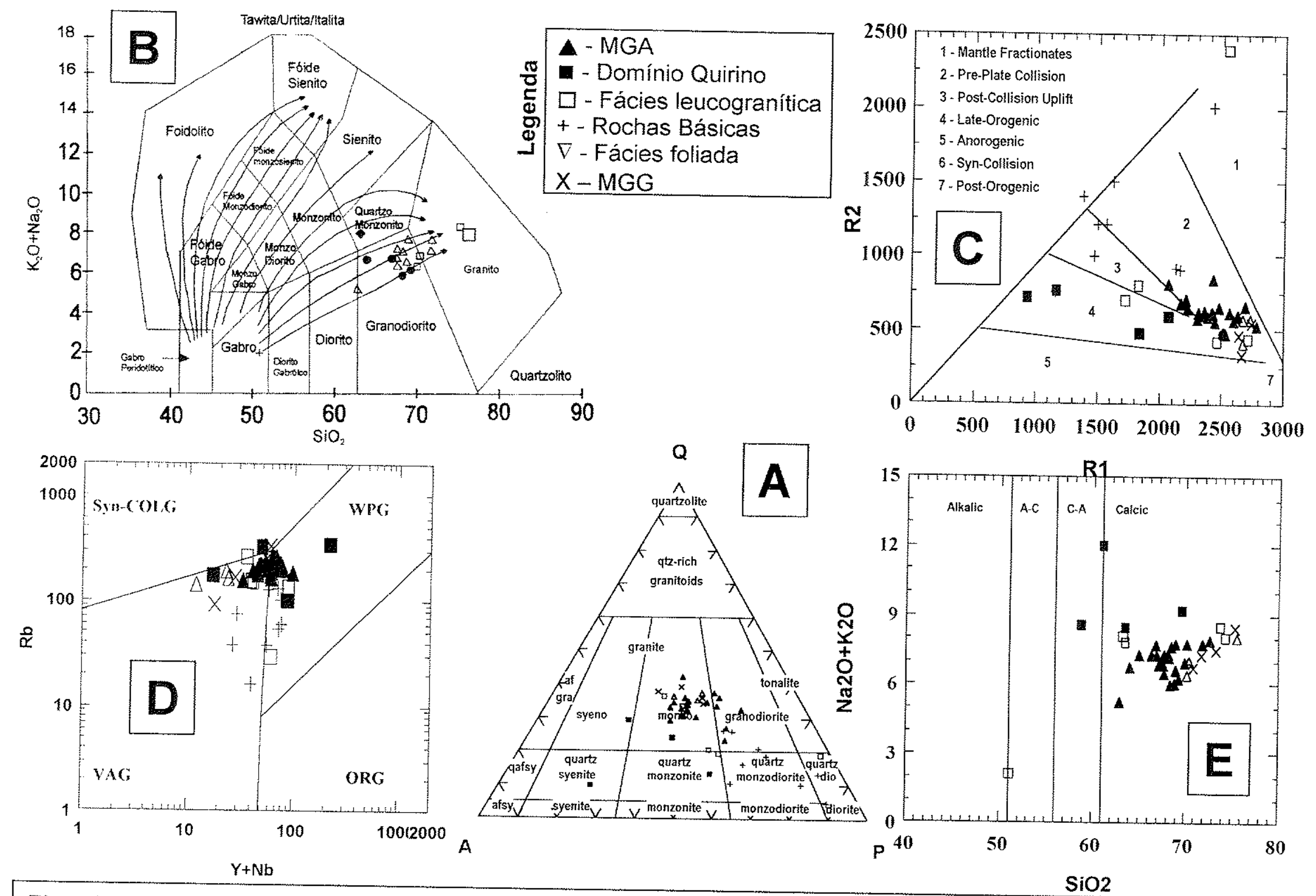

Fig.4.14. Diagrama de classificação de Streckeisen (1976)(A) e diagramas de discriminação de ambientes tectônicos para a Suite Intrusiva Arrozal: (B) Middlemost (1999) com trends das séries magmáticas; (C) Batchelor \& Bowden(1985); (D) Pearce (1984) e (E) Peacock (1931). 
Dom Feliciano ( $\mathrm{Ba}_{\mathrm{ORG}}<10, \mathrm{Nb}_{\mathrm{ORG}}<2$ e $\mathrm{Zr}$ ORG $<0.5$ ) apresentados por Bitencourt \& Nardi (2000).

Estes autores, reconhecem quatro grandes grupos de magmas graníticos associados aos cisalhamentos transcorrentes do estágio pós-colisional: (a) granitóides cálcio alcalinos de alto K; (b) granitóides peraluminosos; (c) granitóides shoshoníticos; e (d) granitóides alcalinos. Todos estes podem ser discriminados entre si a partir de associações de campo, variabilidade de tipos petrográficos e geoquímica de elementos traços.

\subsubsection{Maciço Granitico Getulândia (MGG)}

O MGG possui composição monzogranítica, de granulação média a grossa, textura inequigranular a localmente porfirítica, com foliação magmática na porção central, que grada para uma foliação acentuada no estado sólido em direção às bordas, sobretudo no seu contato noroeste.

As amostras do MGG (GPR 221 e GPR 222), com teores em SiO2 entre 70,8 a $75,3 \%$, sugerem corresponder a termos mais evoluidos do que as faciologias associadas ao MGA. De acordo com os estudos de Valladares (1996) e Valladares et al. (2000), o MGG apresenta composições variáveis entre 66 e $74 \%$ em SiO2.

Os demais parâmetros geoquímicos parecem confirmar esta estreita relação entre os maciços para valores idênticos em SiO2: índice A/CNK ligeiramente peraluminoso $(1,16)$; $\mathrm{K} 2 \mathrm{O}>4,0 \%(4,3$ e $5,6 \%), \mathrm{K} 2 \mathrm{O} / \mathrm{Na} 2 \mathrm{O}>1,80$, e conteúdos globais semelhantes em elementos traços, juntamente com as mesmas tendências de correlação negativa para $\mathrm{Ba}$, $\mathrm{Sr}, \mathrm{Zr}$ com a SiO2, e positiva com o Rb.

Os valores de indice de saturação em alumina entre 1,10 e 1,15 são similares aos valores apresentados pelas fácies porfirítica e foliada do MGA, situando-se no limite de valores do granitos tipo-I (entre 0,9 e 1,1) e tipo-S (entre 1,1 e 1,4) australianos (Chappell \& White 1992).

Os conteúdos em Rb entre 252 e 327 ppm são mais elevados do que das faciologias do MGA, cujos valores situam-se no intervalo dos granitos fracionados autralianos (Chappell \& White 1992), reafirmando assim o caráter mais evoluido deste maciço em relação ao MGA. 


\section{$\checkmark$ Discussão dos resultados}

O comportamento dos elementos maiores traços selecionados é muito semelhante entre as faciologias do MGA e do MGG, sobretudo entre as fácies porfiritica e foliada do primeiro, mostrando que o processo deformacional (no estado sólido) não foi suficiente para promover alterações importantes do comportamento químico desses elementos, conforme sugerido pelos diferentes diagramas utilizados.

A comparação entre as duas suítes permite destacar os seguintes aspectos:

- Correlação negativa do $\mathrm{Sr}, \mathrm{Ba}$ e $\mathrm{Zr}$ com a $\mathrm{SiO}_{2}$, refletindo em ambos os casos processos magmáticos relacionados à cristalização contínua de feldspatos e zircão;

- Correlação positiva de $\mathrm{K}$ e Rb, refletindo da mesma maneira a cristalização de feldspato de potássio, durante o processo de cristalização fracionada;

- Correlação negativa do soma FMMT $\left(\mathrm{Fe}_{2} \mathrm{O}_{3}+\mathrm{MgO}+\mathrm{MnO}+\mathrm{TiO}_{2}\right) \mathrm{com}$ a $\mathrm{SiO}_{2}$ é compativel com a cristalização continua de minerais ferro-magnesianos (sobretudo biotita, ilmenita e magnetita) nas diferentes faciologias do MGA;

- Superposição no diagrama de saturação em alumina entre as amostras das fácies porfirítica e foliada, com o índice A/CNK entre 1,0 e 1,2 caracterizando este magmatismo como marginalmente peraluminoso. Este índice superpõe-se aos dos granitos Pré-F2 (entre 1,05 e 1,2) e Tardi a Pós-F3 (entre 1,1 e 1,17) dos granitos Neoproterozóicos do estado do Rio de Janeiro (Machado 1997). Além disso, este intervalo de valores situa-se no limite dos granitos tipo-I (entre 0,9 e 1,1) e tipo-S (entre 1,1 e 1,4) caracterizados para os granitos australianos (Chappell \& White 1992);

- A existência de amostras mais enriquecidas em $\mathrm{SiO}_{2}$ nas rochas deformadas (fácies foliada) pode ser devido ao aumento deste elemento promovido por uma fase fluida, que acompanhou o processo de deformação no estado sub sólido, ou mesmo ocasionado pela existência de termos mais evoluídos na porção deformada do maciço;

- Distribuição das faciologias estudadas no campo de granitos tardi e póstectônicos no diagrama contendo os granitos neoproterozóicos da região do 
vale do Rio Doce, nos estados do Espírito Santo e de Minas Gerais (Bilal et al 2000);

Os dados aqui discutidos permitem caracterizar o MGA como um maciço de composição não-expandida (predominância de monzogranitos), associados à zona de cisalhamento de alto ângulo, posicionado tardiamente ao metamorfismo regional, sendo comparável ao magmatismo Neoproterozóico tardi- a pós-orogênico descrito em outras porções dos Cinturões Paraíba do Sul (RJ e ES) e Dom Feliciano (SC e RS) (Junho 1993; Wiedeman 1993, Figueiredo \& Campos Neto 1993, Machado 1997, Bilal et al. 2000, Philipp 1998, Philipp et al. 1997, Nardi \& Bitencourt 1993, Bitencourt 1996, Lima \& Nardi 1998, Fernandes et al 1999, Bitencourt \& Nardi 2000, dentre outros).

A SIA, apesar das diferenças de idade, é comparável aos granitóides cálcio-alcalinos alto K ou até mesmo shoshoníticos do cinturão Dom Feliciano (Nardi \& Bitencourt 1993, Bitencourt \& Nardi 2000).

A comparação dos dados geoquímicos disponíveis na literatrura sobre os maciços Pedra Branca, Frades, Nova Friburgo e Sana (Junho \& Penha 1985, Junho et al. 1987, 1991 e 1993; Junho 1990 e 1993, Machado 1997), com os valores obtidos neste trabalho, mostra teores semelhantes em $\mathrm{Al}_{2} \mathrm{O}_{3}$ (14 a 15\%); $\mathrm{CaO}$ (1,4 a 4,6\%); $\mathrm{MgO}(0,3$ a 2,9\%); Rb (158 a 400 ppm.); relativamente alto em $\mathrm{K}_{2} \mathrm{O}(3,4$ e 6,2\%), e superiores em $\mathrm{Sr}$ (250 a 1140 ppm.) e $\mathrm{Ba}(1300$ a $3300 \mathrm{ppm}$.). 


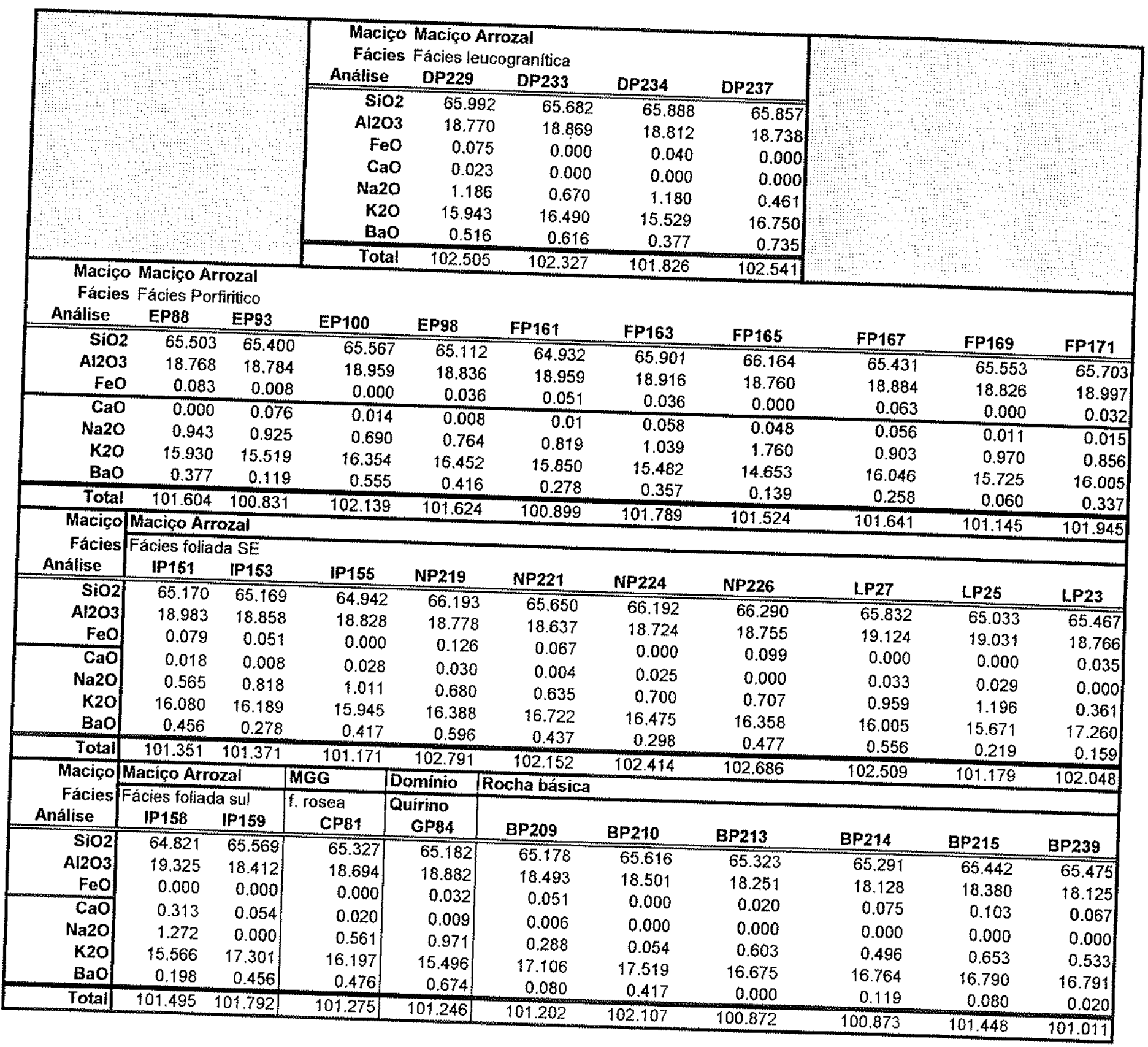




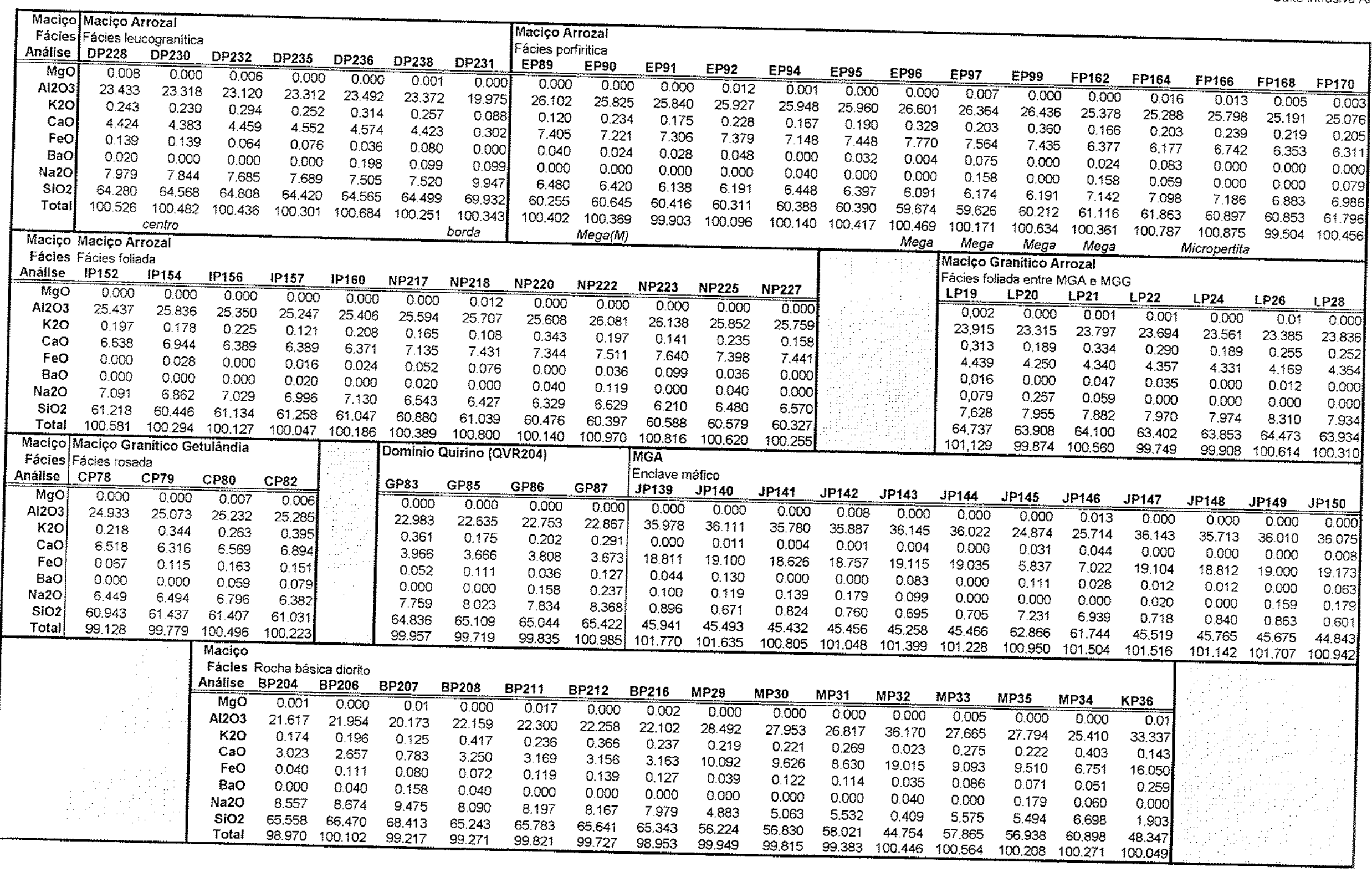


Tabela 4.3.

\begin{tabular}{|c|c|c|c|c|c|c|c|c|c|c|c|c|c|c|c|c|}
\hline \begin{tabular}{|l|} 
Macico \\
Fácies \\
Análise \\
\end{tabular} & \multicolumn{8}{|c|}{$\begin{array}{l}\text { Maciço Arrozal } \\
\text { Fácies quartzo monzonito leucocrático } \\
\begin{array}{llll}\text { DP178 DP179 DP } 180 & \text { DP181 }\end{array}\end{array}$} & \multicolumn{8}{|c|}{$\begin{array}{l}\text { Macico Arrozal } \\
\text { Facies Porfiritica (central) }\end{array}$} \\
\hline 5102 & 35,70 & 35,69 & 35,61 & 36,14 & 35.49 & 35,60 & 35,20 & 35,61 & 35,69 & 35.71 & 35.91 & 35,79 & 35,73 & 35,28 & 35,81 & 35,22 \\
\hline TiO2 & 2,86 & 3,19 & 3,13 & 3,32 & 3,28 & 3,23 & 3,26 & 3,96 & 3,24 & 3,74 & 3.57 & 3,46 & 3,55 & 3,34 & 3,12 & 3,53 \\
\hline Al2O3 & 13.95 & 13,61 & $\begin{array}{l}13,69 \\
0.64\end{array}$ & 13.89 & 13,72 & 14,04 & 13,88 & 13,66 & 17,47 & 17,40 & 17,27 & 17,21 & 17.50 & 17.61 & 17,48 & 17,40 \\
\hline $\begin{array}{l}\mathrm{Cr} 2 \mathrm{O} 3 \\
\mathrm{FeO}\end{array}$ & $\begin{array}{c}0.04 \\
2814\end{array}$ & $\begin{array}{l}0,00 \\
27,65\end{array}$ & $\begin{array}{r}0,04 \\
288 ? 3\end{array}$ & 0.00 & 0.02 & 0,03 & 0,03 & 0,00 & 0.01 & 0,04 & 0,00 & 0,04 & 0,03 & 0,00 & 0.00 & 0,05 \\
\hline $\begin{array}{l}\text { Teo } \\
\text { miono }\end{array}$ & $\begin{array}{l}28,14 \\
0.45\end{array}$ & 27,65 & 28,23 & 27,98 & 27,56 & 28,36 & 27.03 & 27.98 & 21,95 & 22,22 & 22,27 & 22,27 & 23,15 & 21,97 & 21,81 & 22,40 \\
\hline $\begin{array}{l}\text { Mno } \\
\text { MaO }\end{array}$ & $\begin{array}{l}0,45 \\
6843\end{array}$ & $\begin{array}{l}0,41 \\
6,35\end{array}$ & $\begin{array}{l}0.42 \\
6.26\end{array}$ & 0,43 & 0.40 & 0,44 & 0,43 & 0,41 & 0,21 & 0,12 & 0,19 & 0.24 & 0,21 & 0,20 & 0.13 & 0,24 \\
\hline $\begin{array}{l}\text { Mgo } \\
\mathrm{CaO}\end{array}$ & $\begin{array}{l}6,43 \\
0,00\end{array}$ & $\begin{array}{l}6,35 \\
0,00\end{array}$ & $\begin{array}{l}6,26 \\
0,00\end{array}$ & $\begin{array}{l}5,88 \\
001\end{array}$ & 5,93 & 6,06 & 6.03 & 5.75 & 7.58 & 7,54 & 7.43 & 7.44 & 7,44 & 7,42 & 7,65 & 7,52 \\
\hline $\mathrm{Na2O}$ & 0,00 & 0,00 & 0,00 & 0,00 & 0,005 & 0,00 & 0,04 & 0,03 & 0.09 & 0,03 & 0,08 & 0,06 & 0,00 & 0,01 & 0,05 & 0.12 \\
\hline K2O & 10,05 & 9,90 & 9,83 & 9.94 & & 0,00 & 0,00 & 0,00 & 0,03 & 0.00 & 0,00 & 0,00 & 0,00 & 0,00 & 0,09 & 0,02 \\
\hline$\sigma_{5}$ & 0,31 & 0,09 & 0,44 & 0,18 & $\begin{array}{l}9,65 \\
0,62\end{array}$ & $\begin{array}{l}9,76 \\
0,35\end{array}$ & $\begin{array}{l}9,90 \\
0,09\end{array}$ & 9.81 & 9,77 & 9,87 & 9,80 & 9,88 & 10,04 & 9,82 & 9,92 & 9,81 \\
\hline & 0,20 & 0,24 & 0,21 & 0,26 & 0.19 & $\begin{array}{l}0,35 \\
0,24\end{array}$ & 0,09 & 0.18 & 0.37 & 0,46 & 0,51 & 0,28 & 0,97 & 0,23 & 1,00 & 0.28 \\
\hline 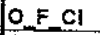 & 0.17 & 0,09 & 0,23 & 0.13 & 0,30 & $\begin{array}{l}0,24 \\
0,20\end{array}$ & $\begin{array}{l}0,22 \\
0,09\end{array}$ & $\begin{array}{l}0.19 \\
0.12\end{array}$ & $\begin{array}{l}0,16 \\
0,19\end{array}$ & $\begin{array}{l}0,14 \\
0.22\end{array}$ & $\begin{array}{l}0,18 \\
0,25\end{array}$ & $\begin{array}{l}0,20 \\
0.16\end{array}$ & 0.17 & 0.21 & 0,20 & 0,16 \\
\hline \multirow[t]{2}{*}{ Total } & 97,94 & 37.05 & 97,61 & 97,88 & 96.61 & 97,90 & 96,02 & $\frac{0,12}{97,46}$ & $\begin{array}{l}0,19 \\
96,36\end{array}$ & $\frac{0.22}{97,05}$ & $\frac{0,25}{96,95}$ & $\begin{array}{l}0,16 \\
96,71\end{array}$ & $\frac{0,44}{98,33}$ & $\frac{0,14}{95,96}$ & $\frac{0.47}{96,80}$ & $\frac{0,15}{96,57}$ \\
\hline & & & & & & & & & & & & & & & & 80,27 \\
\hline aIIV & $\begin{array}{l}5.598 \\
2.402\end{array}$ & $\begin{array}{l}5,628 \\
2372\end{array}$ & $\begin{array}{l}5,607 \\
2393\end{array}$ & $\begin{array}{l}5,651 \\
2,349\end{array}$ & $\begin{array}{l}2,632 \\
2,368\end{array}$ & $\begin{array}{l}2,584 \\
2.416\end{array}$ & $\begin{array}{l}5,604 \\
2,396\end{array}$ & $\begin{array}{l}5.599 \\
2401\end{array}$ & 5,478 & 5.452 & 5,490 & 5,486 & 5,428 & 5,443 & 5,492 & 5,415 \\
\hline Somaz & 8,000 & $\begin{array}{r}2,372 \\
8,000\end{array}$ & $\frac{2,393}{8,000}$ & $\begin{array}{l}\frac{3.349}{8.000} \\
\end{array}$ & 8000 & 8,000 & $\frac{2,050}{8,000}$ & $\frac{2.401}{8.000}$ & $\frac{2,522}{8000}$ & 2.548 & 2,510 & 2.514 & 2.572 & 2,557 & 2.508 & 2,585 \\
\hline Alv1 & 0,175 & 0,159 & 0.147 & 0,210 & 0.198 & 0,180 & 0,209 & $\frac{0.000}{0.129}$ & $\frac{8,000}{0.30}$ & 8,000 & 8,000 & 8.000 & 8.000 & 8.000 & 8.000 & 8.000 \\
\hline $\mathrm{Ti}$ & 0,338 & 0,378 & 0.370 & 0,390 & 0,392 & 0.381 & 0,390 & 0.469 & 0,639 & 0,582 & 0,604 & 0,594 & 0,562 & 0,645 & 0.553 & 0.567 \\
\hline $\mathrm{Cr}$ & 0.004 & 0,000 & 0,004 & 0,000 & 0,003 & 0,003 & 0,004 & $\begin{array}{l}0,459 \\
0,000\end{array}$ & $\begin{array}{l}0,374 \\
0,001\end{array}$ & 0,430 & 0,410 & 0,399 & 0,405 & 0,388 & 0,359 & 0,408 \\
\hline$F e 2 t$ & 3,589 & 3.646 & 3.717 & 3,658 & 3.658 & 3,720 & 3.599 & 3,678 & $\begin{array}{l}0,001 \\
2,817\end{array}$ & $\begin{array}{l}0,004 \\
2836\end{array}$ & 0,000 & 0.005 & 0.004 & 0,000 & 0,000 & 0,006 \\
\hline $\mathrm{Mn}$ & 0.060 & 0,055 & 0.056 & 0,057 & 0,054 & 0,058 & 0.058 & 0,055 & 0.027 & $\begin{array}{l}2,836 \\
0,016\end{array}$ & 2,847 & 2,854 & 2,941 & 2,835 & 2,797 & 2,880 \\
\hline & 1502 & 1.494 & 1,469 & 1,371 & 1.402 & 1,417 & $\uparrow, 431$ & 1,348 & 1735 & 0.016 & 0,025 & 0.031 & 0,027 & 0,026 & 0.017 & 0.031 \\
\hline SornaY & 5.769 & 5,732 & 5,763 & 5,687 & 5.707 & 5.759 & 5,690 & 5,679 & 5,593 & $\frac{1,717}{5,585}$ & 1,693 & 1.699 & 1,686 & 1.707 & 1.750 & 1,723 \\
\hline $\mathrm{ca}$ & 0,000 & 0,000 & 0,000 & 0.002 & 0.000 & 0.000 & 0,006 & 0005 & $\frac{3.035}{0.015}$ & 5,585 & 5,576 & 5,582 & 5,624 & 5,600 & 5,576 & $5.6+5$ \\
\hline $\mathrm{Na}$ & 0,000 & 0.000 & 0,000 & 0,000 & 0.015 & 0,000 & 0,000 & 0000 & $\begin{array}{l}0,015 \\
0,008\end{array}$ & 0.005 & 0,013 & 0,041 & 0,000 & 0,002 & 0,008 & 0,020 \\
\hline K & 2,010 & 1,992 & 1,974 & 1,982 & 1,952 & 1,953 & 2,011 & 1,967 & 1912 & 0,000 & 0,000 & 0,000 & 0.000 & 0.000 & 0,026 & 0,005 \\
\hline Somax & 2,010 & 1,992 & 1,974 & 1.984 & 1,968 & $\frac{1,953}{1,953}$ & 2,018 & 1,972 & $\frac{\frac{1,912}{1,935}}{1.96}$ & $\frac{1,923}{1,328}$ & 1,912 & 1.932 & $\frac{1,947}{191}$ & 1,933 & 1.949 & 1.923 \\
\hline Total & 15,779 & 15,724 & 15,738 & 15,670 & 15,675 & 15,712 & 15,708 & $15,65\}$ & $\frac{1,205}{15528}$ & $\frac{1,928}{15513}$ & 1,924 & 1,942 & 1,947 & 1,935 & 1,975 & 1,947 \\
\hline$F$ & 0,15 & 0,04 & $\overline{0.22}$ & 0,09 & 0,31 & 0,17 & 0,05 & 0,09 & 0.028 & $\frac{15,513}{03}$ & 15,501 & 15,525 & 15,571 & 15,535 & 15,552 & 15,562 \\
\hline $\mathrm{Cl}$ & 0,05 & 0,06 & 0.05 & 0.07 & 0,05 & 0.06 & 0,06 & 0,05 & 0, & 0.22 & 0,24 & 0,13 & 0,46 & 0,11 & 0,48 & 0.13 \\
\hline $\mathrm{Mg} \#$ & 0,29 & 0,29 & 0,28 & 0,27 & 0.28 & 0,28 & 0,28 & $\frac{, 05}{0,27}$ & $\frac{0,04}{0,38}$ & $\frac{0,04}{0,38}$ & 0,05 & 0,05 & 0,04 & 0,05 & 0,05 & 0,04 \\
\hline Aft & 2,577 & 2,530 & 2,540 & 2,559 & 2.566 & 2,595 & 2,605 & 2,531 & 3,161 & $\begin{array}{r}0,38 \\
3,130\end{array}$ & $\begin{array}{l}0,37 \\
3111\end{array}$ & $\begin{array}{c}0,37 \\
3.109\end{array}$ & $\begin{array}{l}0,36 \\
3134\end{array}$ & 0,38 & 0,38 & 0.37 \\
\hline & & & & & & & & & & & & & 3,134 & 3,202 & 3.160 & 3,152 \\
\hline
\end{tabular}


Tabela 4.4.

\begin{tabular}{|c|c|c|c|c|c|c|c|c|c|c|c|c|c|c|c|c|c|c|c|}
\hline $\begin{array}{l}\text { Macico } \\
\text { Fácles } \\
\text { Análise }\end{array}$ & \multicolumn{19}{|c|}{$\begin{array}{l}\text { Macica Arrozal } \\
\text { Fáies Porfirtica (central) } \\
\text { FP116 FP117 FP118 }\end{array}$} \\
\hline S1O2 & 35,35 & 35,98 & $\frac{F P 118}{35,55}$ & $\frac{F P 119}{35,18}$ & $\frac{r+726}{35,28}$ & 35,51 & $\frac{122}{35,72}$ & $\frac{57723}{35,10}$ & $\frac{F P 124}{35,58}$ & $\frac{F P 125}{3556}$ & $\frac{\text { FP126 }}{35 \sqrt{69}}$ & NP186 & NP187 & NP188 & NP189 & NP190 & NP191 & NP192 & NP193 \\
\hline TiO2 & 2.46 & 2,61 & 3,17 & 3,61 & 3,78 & 3,28 & 2,80 & 3,20 & 3,17 & $\begin{array}{l}3,5,00 \\
3,00\end{array}$ & $\begin{array}{l}35,69 \\
281\end{array}$ & 37,15 & 37,16 & 37,17 & 36,79 & 37,14 & 36,98 & 36,22 & 37,24 \\
\hline Al2O3 & 16,54 & 17,30 & 16,33 & 16.47 & 16,42 & 16,87 & 16,73 & 16,52 & 16,96 & 16,66 & $\begin{array}{l}2,81 \\
16,71\end{array}$ & 2,68 & 3,19 & 3.01 & 2,54 & 2,64 & 3,08 & 2,88 & 3,00 \\
\hline Cr2O3 & 0,00 & 0,00 & 0,04 & 0,00 & 0,00 & 0,00 & 0,03 & 0,00 & 0,02 & $\begin{array}{l}10,00 \\
0,05\end{array}$ & $\begin{array}{l}16,71 \\
0.02\end{array}$ & 16,35 & 16,35 & 17,18 & 16,05 & 16,36 & 16,23 & 16,63 & 16,00 \\
\hline $\mathrm{FeO}$ & 23,19 & 23,04 & 23,31 & 23,58 & 23,48 & 22,80 & $\begin{array}{c}23,02 \\
23\end{array}$ & 23,75 & 23,19 & 23,05 & $\begin{array}{r}0,02 \\
22,86\end{array}$ & 0,06 & 0,06 & 0,05 & 0,09 & 0.05 & 0.01 & 0,06 & 0,01 \\
\hline Mno & 0,19 & 0,20 & 0,14 & 0,17 & 0,21 & 0,27 & 0,18 & 0,02 & 0,30 & 0,23 & $\begin{array}{l}22,86 \\
0,32\end{array}$ & 20,68 & 20,60 & 20,04 & 19,84 & 20,70 & 20,27 & 21,51 & 21,10 \\
\hline Migo & 7,39 & 7,55 & 7.12 & 6,98 & 7,23 & 7,43 & 7,29 & 6,78 & 7,22 & 7,44 & 0,32 & 0,21 & 0.26 & 0,23 & 0,17 & 0,18 & 0,30 & 0,28 & 0,22 \\
\hline $\mathrm{CaO}$ & 0,05 & 0,01 & 0,01 & 0,00 & 0,00 & 0,00 & 0,06 & 0.07 & 0.01 & & 7,32 & 9,15 & 9,40 & 9,41 & 10,34 & 9,41 & 9,63 & 9,69 & 3,76 \\
\hline $\mathrm{Na} 2 \mathrm{O}$ & 0.02 & 0,04 & 0.00 & 0,00 & 0,00 & 0,00 & 0,04 & 0,05 & 0,00 & 0,02 & 0,01 & 0,10 & 0,00 & 0,02 & 0,04 & 0,42 & 0,07 & 0,31 & 0,01 \\
\hline K2O & 9,66 & 9,95 & 8,43 & 9.93 & 9,89 & 8,83 & 9,44 & 9,64 & 9,86 & $\begin{array}{l}0,03 \\
9,68\end{array}$ & 0,00 & 0,01 & 0,00 & 0,02 & 0,00 & 0,00 & 0,00 & 0,00 & 0,00 \\
\hline$F$ & 0.50 & 0,00 & 0,82 & 0,41 & 0,00 & 1,17 & 0,35 & 0,36 & 0,77 & $\begin{array}{l}9,68 \\
0,50\end{array}$ & $\begin{array}{l}8,55 \\
027\end{array}$ & 9,84 & 10,18 & 10,06 & 10,15 & 10,36 & 19,97 & 9,18 & 10.18 \\
\hline & 0.21 & 0,25 & 0,20 & 0,25 & 0,24 & 0,22 & 0,23 & 0,25 & 0,17 & 020 & 0,27 & 0,23 & 0,00 & 0,00 & 0,51 & 0,51 & 0,69 & 0,56 & 1.08 \\
\hline O_F Cl & 0,26 & 0,06 & 0,39 & 0,23 & 0,05 & 0,54 & 0.45 & $0,2 i$ & 0,36 & 0,26 & 0,24 & 0,24 & 0,24 & 0,24 & 0,25 & 0,27 & 0,24 & 0,26 & 0,27 \\
\hline Total & 95.31 & 96.87 & 95.74 & 96,36 & 96.46 & 96,94 & 98.04 & 95,54 & 96,88 & $\frac{1,20}{96,15}$ & $\frac{0,17}{95,64}$ & $\frac{0.15}{96.58}$ & $\frac{0,05}{9738}$ & $\frac{0,06}{9738}$ & $\frac{0,27}{9550}$ & $\frac{0,27}{9777}$ & 0,35 & 0,29 & 0,52 \\
\hline & & & & & & & & & & & & & & & & 97,77 & 107.13 & 97,27 & 98,34 \\
\hline $\begin{array}{l}\text { li } \\
\text { Ailv }\end{array}$ & $\begin{array}{r}5,538 \\
2,62\end{array}$ & 5,515 & 5,545 & 5,470 & 5,460 & 5.483 & 5,547 & 5.497 & 5.488 & 5,513 & 5,545 & 5,6 & 5.5 & 5,572 & 5,599 & 5,605 & 5364 & & \\
\hline Somaz & $\frac{2,462}{8,000}$ & $\frac{2,485}{8000}$ & 2.455 & 2,530 & 2.540 & 2,517 & 2,453 & & 2.5 & 2,487 & 2.4 & 2,3 & 2,40 & 2,428 & 2,401 & 2,395 & $\begin{array}{l}\quad, 304 \\
2,636\end{array}$ & $\begin{array}{l}3,442 \\
2,508\end{array}$ & $\begin{array}{l}5,605 \\
2,395\end{array}$ \\
\hline AIVI & 0.591 & 0.638 & $\frac{8,000}{0,547}$ & $\frac{8,000}{0.487}$ & $\frac{8.000}{0.54}$ & 8,000 & 8.000 & 8,000 & 8,000 & 8,000 & 8,000 & 8,000 & 8.000 & 8.000 & 8,000 & 8,000 & 8,000 & 8,000 & $\frac{1,000}{8,000}$ \\
\hline$n$ & 0.290 & 0.301 & 0,372 & $\begin{array}{l}0.487 \\
0.422\end{array}$ & $\begin{array}{l}0.454 \\
0.440\end{array}$ & $\begin{array}{l}0,553 \\
0.381\end{array}$ & 0.609 & 0.546 & $0, \overline{571}$ & 0.556 & 0.605 & 0,570 & 0,500 & 0,608 & 0.479 & 0,515 & 0.139 & 0,463 & 0,444 \\
\hline $\mathrm{cr}_{r}$ & 0,000 & 0,000 & 0,005 & 0,000 & 0,000 & $\begin{array}{l}0,381 \\
0,000\end{array}$ & 0.327 & 0,376 & 0,368 & 0,350 & 0.329 & 0.307 & 0,361 & 0,340 & 0.291 & 0,300 & 0.336 & 0,329 & 0,340 \\
\hline Fezt & 3,038 & 2,952 & 3,041 & 3,065 & 3.038 & 2,944 & $\begin{array}{l}0,004 \\
2.990\end{array}$ & $\begin{array}{l}0,000 \\
3110\end{array}$ & $\begin{array}{l}0,002 \\
2,992\end{array}$ & 0,006 & 0,003 & 0.007 & 0,007 & 0,006 & 0,011 & 0.006 & 0,001 & 0.007 & 0.001 \\
\hline $\mathrm{Mn}$ & 0.025 & 0,026 & 0.019 & 0,023 & 0,027 & 0,035 & 0,024 & $\begin{array}{l}3,110 \\
0,003\end{array}$ & $\begin{array}{l}2,932 \\
0.039\end{array}$ & $\begin{array}{l}2.989 \\
0,030\end{array}$ & $\begin{array}{l}2,970 \\
0,043\end{array}$ & $\begin{array}{l}2,627 \\
0,027\end{array}$ & $\begin{array}{l}2,595 \\
0,033\end{array}$ & 2,512 & 2,525 & 2.612 & 2,459 & 2,727 & 2.655 \\
\hline $\mathrm{Mg}$ & 1,726 & 1.726 & 1.656 & 1,617 & 1,667 & 1.711 & 1.688 & 1,584 & 1,659 & $\begin{array}{l}1,719 \\
1,9\end{array}$ & $\begin{array}{l}1,696 \\
1.596\end{array}$ & 2,073 & 2112 & $\begin{array}{l}0,029 \\
2104\end{array}$ & 0,022 & 0.023 & 0,036 & 0,036 & 0,028 \\
\hline SomaY & 5,669 & 5642 & 5,640 & 5,614 & 5,627 & 5,623 & 5,642 & 5,619 & 5,631 & 5,649 & 5,6 & 5613 & 5.6 & $\frac{2,104}{5600}$ & $\begin{array}{l}2,346 \\
5.774\end{array}$ & 2,118 & 2.083 & 2.190 & 2.189 \\
\hline $\mathrm{Ca}$ & 0.009 & 0,001 & 0,001 & 0,000 & 0,000 & 0,000 & 0,009 & 0,012 & 0,001 & 0,003 & $\frac{0,040}{0002}$ & 2,0 & 0,000 & 3,600 & 5,674 & 5,573 & 5,054 & 5.752 & 5,657 \\
\hline $\mathrm{Na}$ & 0.006 & 0,013 & 0,000 & 0,000 & 0,000 & 0,000 & 0,013 & 0016 & 0,000 & 0 & 0 & & 0,000 & 0,003 & 0,006 & 0,068 & 0.011 & 0,051 & 0,001 \\
\hline k & ฬ,931 & 1,945 & 1,877 & 1,970 & 1,952 & 1,956 & 1.869 & 1926 & 1939 & 1914 & 1893 & 0,004 & & 0,006 & 0,000 & 0,0 & 0,0 & 0,000 & 0,000 \\
\hline SomaX & 1.946 & 1,960 & 1,878 & 1,970 & 1,952 & 1,956 & 1,892 & $\frac{1,960}{1,954}$ & $\frac{1,9050}{1,940}$ & $\frac{1,914}{1,925}$ & $\frac{1.893}{1.895}$ & $\frac{7,906}{1926}$ & $\frac{1,957}{1957}$ & $\frac{1,923}{1,932}$ & 1,971 & 1,994 & 3,695 & 1,775 & 1,954 \\
\hline Total & 15,615 & 15,602 & 15.518 & 15,584 & 15,579 & 15,579 & 15,534 & 15,573 & 15,571 & $\frac{1,560}{15,574}$ & 15,541 & 15,538 & $\frac{1,907}{15565}$ & $\frac{1,932}{15531}$ & 1,976 & 2061 & 3,705 & 1.826 & 1.955 \\
\hline$r$ & 0,25 & 0,00 & 0,40 & 0,20 & 0,00 & 0.57 & 047 & 0,8 & 0,38 & 0.25 & 013 & 011 & $\frac{12,300}{000}$ & 15,531 & 15,650 & 15,635 & 16,759 & 15,578 & 15,612 \\
\hline $\mathrm{Cl}$ & 0,06 & 0,07 & 0.05 & 0,07 & 0,06 & 0,06 & $\begin{array}{l}0,41 \\
0.06\end{array}$ & 0.07 & 0.04 & 0,20 & 0 & 0,17 & 0,00 & $0, \infty$ & 0,24 & 0.24 & 0,32 & 0,27 & 0.52 \\
\hline Mg\# & 0,36 & 0,37 & 0,35 & 0,35 & 0,35 & 0,37 & 0,36 & 0,3 & 0,04 & $\frac{0,05}{0,37}$ & 0,00 & 0.08 & $\frac{0,06}{0.45}$ & 0,06 & 0,05 & 0,07 & 0,06 & 0,07 & 0,07 \\
\hline Alt & 3.053 & 3,124 & 3,003 & 3,017 & 2,994 & 3,070 & 3,062 & 3,049 & 3,083 & $\begin{array}{l}0,017 \\
3,043\end{array}$ & 3,060 & 2,927 & $\begin{array}{r}0,45 \\
2,902\end{array}$ & 0,46 & 0,48 & 0,45 & 0,46 & 0,45 & 0,45 \\
\hline
\end{tabular}


Tabela 4.5.

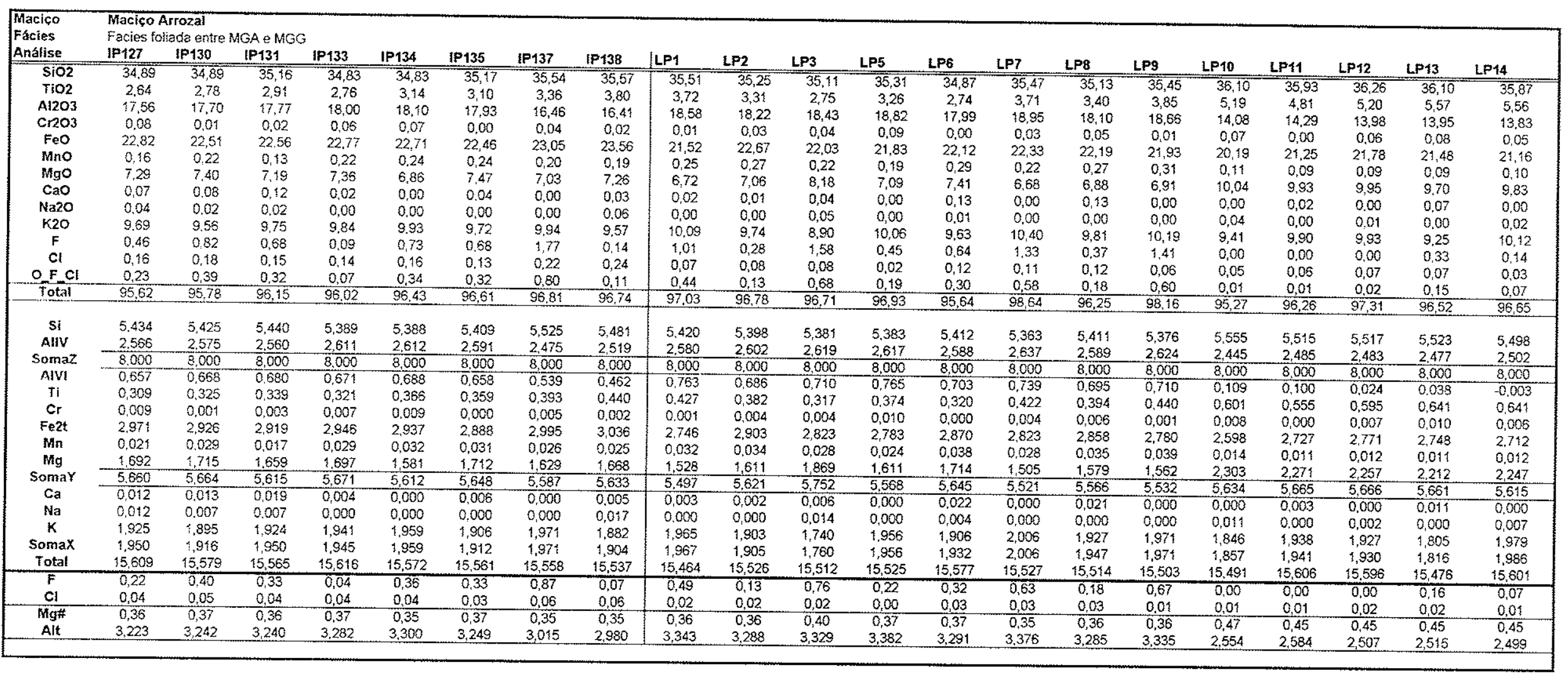


Tabela 4.6.

\begin{tabular}{|c|c|c|c|c|c|c|c|c|c|c|c|c|c|c|c|c|c|c|c|}
\hline \multicolumn{6}{|c|}{$\begin{array}{l}\text { Maciço Grantitico Getulandia } \\
\text { Fácies rósea }\end{array}$} & \multicolumn{7}{|c|}{ Dominio Quirino } & \multicolumn{7}{|c|}{$\begin{array}{l}\text { Rocha básica intrusiva no MGG } \\
\text { Enclave máfico }\end{array}$} \\
\hline $\mathrm{SiO2}$ & 36,61 & $\frac{r}{36,84}$ & $\frac{c 48}{36.71}$ & $\frac{\text { CP49 }}{36,64}$ & $\frac{\text { CP701 }}{36.65}$ & $\frac{\text { GP50 }}{34,72}$ & $\frac{\text { GP51 }}{3500}$ & $\frac{\text { GP52 }}{3466}$ & $\frac{\text { GP53 }}{3483}$ & $\frac{\text { GP54 }}{3456}$ & GP55 & GP56 & JP115 & BP194 & BP195 & BP196 & BP197 & BP198 & BP 199 \\
\hline $\mathrm{THO}^{2}$ & 3,62 & 2,95 & 2,76 & 2,83 & 4,34 & 5,06 & $\begin{array}{l}55,000 \\
5,30\end{array}$ & $\begin{array}{c}34,66 \\
4,84\end{array}$ & $\begin{array}{c}34,83 \\
5,45\end{array}$ & $\begin{array}{c}34,56 \\
4,99\end{array}$ & $\begin{array}{l}34,12 \\
5,5\end{array}$ & 34,31 & 40,37 & 34.32 & 35,11 & 34,53 & 34,44 & 34,37 & 34,39 \\
\hline $\mathrm{Al} 2 \mathrm{O} 3$ & 15,41 & 15,44 & 15,59 & 14,93 & 14,21 & 13,41 & 13,54 & 13,32 & 13,48 & 13.45 & $\begin{array}{r}5,15 \\
13,30\end{array}$ & $\begin{array}{c}5,30 \\
13,31\end{array}$ & $\begin{array}{l}1,53 \\
1602\end{array}$ & $\begin{array}{l}3,30 \\
1355\end{array}$ & $\begin{array}{r}2,54 \\
\end{array}$ & 3.01 & 3,24 & 3,03 & 3,08 \\
\hline $\mathrm{Cr} 2 \mathrm{O} 3$ & 0,00 & 0.03 & 0,00 & 0,03 & 0,00 & 0,00 & 0,02 & 0,00 & 0,02 & 0,00 & 0,01 & $\begin{array}{l}1,31 \\
0,01\end{array}$ & $\begin{array}{l}16,02 \\
0,04\end{array}$ & $\begin{array}{l}13,55 \\
0,00\end{array}$ & $\begin{array}{l}44,60 \\
0,00\end{array}$ & $\begin{array}{l}13,59 \\
000\end{array}$ & 13,88 & 13,90 & 13,77 \\
\hline $\mathrm{FeO}$ & 20.99 & 20.84 & 20,97 & 20,36 & 20,46 & 30,02 & 29,02 & 23.52 & 29.29 & 29,16 & 28,23 & 29,84 & 12,71 & 32,09 & $\begin{array}{r}0,00 \\
29,96\end{array}$ & 0,00 & 0.01 & 0,00 & 0,02 \\
\hline $\mathrm{MnO}$ & 0,37 & 0,26 & 0,32 & 0,32 & 0,33 & 0.21 & 0,32 & 0,31 & 0.30 & 0,35 & 0.31 & 0.23 & 0.11 & 0.51 & $\begin{array}{l}29,96 \\
0.12\end{array}$ & 30,63 & 31,18 & 31,20 & 31.53 \\
\hline Mgo & 10,02 & 10,31 & 10.01 & 10.26 & 10,80 & 4,72 & 4,53 & 4,55 & 4,45 & 4,48 & 4,48 & 4.47 & & & & & & & \\
\hline CaO & 0,11 & 0,00 & 0,00 & 0.11 & 0,18 & 0,03 & 0,01 & 0,03 & 0,02 & 0,03 & 0,07 & 0,11 & & & & & & & \\
\hline $\mathrm{Na2O}$ & 0.01 & 0,08 & 0,00 & 0,00 & 0.14 & 0,00 & 0,00 & 0,00 & 0,00 & 0,02 & 0.00 & 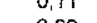 & 0,01 & 0,00 & 0,00 & 0,02 & 0.11 & 0,00 & 0,10 \\
\hline $\mathrm{K} 2 \mathrm{O}$ & 9.42 & 9,60 & 9,79 & 9,62 & 9,37 & 9,63 & 9.45 & 9.36 & 9.79 & 9,43 & 9,26 & 0,00 & 0,00 & 0,00 & 0,00 & 0,00 & 0,00 & 0,00 & 0,00 \\
\hline$F$ & 0,55 & 0,00 & 0,00 & 0,00 & 0,09 & 0.26 & 0,18 & 1,09 & 0,00 & 0,00 & $\begin{array}{l}7,26 \\
0,27\end{array}$ & 9,12 & 9.04 & $\begin{array}{l}9,64 \\
0,30\end{array}$ & 9.28 & 9,75 & 9.52 & 9,69 & 9,33 \\
\hline $\mathrm{Cl}$ & 0,03 & 0,04 & 0,03 & 0,03 & 0,05 & 0,08 & 0,08 & 0,06 & 0,10 & 0,11 & 0,02 & $\begin{array}{l}0,00 \\
0,07\end{array}$ & 0,14 & 0,30 & 0,04 & 0,83 & 0,09 & 0,00 & 0,61 \\
\hline$O_{-} F_{-}$ & 0,24 & 0,01 & 0,01 & 0,01 & 0,05 & 0.13 & 0,09 & 0,47 & 0,02 & 0,02 & 0,12 & $\begin{array}{l}0,07 \\
0,01\end{array}$ & 0,05 & 0.31 & 0.35 & 0.27 & 0,29 & 0,30 & 0,31 \\
\hline Total & 96,90 & 96,37 & 96,17 & 95,13 & 96,56 & 98,01 & 97.37 & 97,26 & 97.71 & 96,47 & 96,10 & 96.75 & $\frac{0,07}{3735}$ & $\frac{0,20}{07.15}$ & $\frac{0,10}{1.07}$ & 0,41 & 0,10 & 0,07 & 0,33 \\
\hline & & & & & & & & & & & & & & 97,15 & 94.87 & 95,49 & 96,01 & 95,60 & 95,87 \\
\hline $\begin{array}{c}\text { Si } \\
\text { Alv }\end{array}$ & $\begin{array}{l}5,551 \\
2439\end{array}$ & 5,603 & 5,604 & 5,644 & 5.571 & 5,486 & 5.529 & 5,531 & 5,499 & 5,521 & 5,484 & 5,475 & 5,773 & 5.639 & 5707 & 5665 & 5600 & & \\
\hline $\begin{array}{l}\text { AIIN } \\
\text { Somaz }\end{array}$ & $\begin{array}{l}2,439 \\
8,000\end{array}$ & $\frac{2,397}{8,000}$ & $\frac{2,396}{8,000}$ & $\frac{2,356}{8000}$ & 2,429 & 2,514 & 2,471 & 2,469 & 2.501 & 2,479 & 2.516 & 2,525 & 2,227 & 2,361 & 2,293 & $\begin{array}{r}0,665 \\
2,335 \\
\end{array}$ & $\begin{array}{l}3,602 \\
2,398\end{array}$ & $\begin{array}{r}2,382 \\
\end{array}$ & 2,374 \\
\hline AIVI & 0,320 & 0,370 & 0,409 & $\begin{array}{l}8,000 \\
0.355\end{array}$ & $\frac{8.000}{0.117}$ & 8,000 & 8,000 & 8,000 & 8,000 & 8,000 & 8,000 & 8,000 & 8,000 & 8,000 & 8,000 & 8.000 & 8.000 & 8.000 & 8,000 \\
\hline $\mathrm{TI}$ & 0,413 & 0,337 & 0,317 & 0,328 & $\begin{array}{l}0.117 \\
0.496\end{array}$ & $\begin{array}{c}-0.018 \\
0.602\end{array}$ & $\begin{array}{l}0.050 \\
0.630\end{array}$ & $\begin{array}{l}0.036 \\
0.581\end{array}$ & 0.006 & 0,053 & 0,004 & $-0,023$ & 0.472 & 0,218 & 0,504 & 0,293 & 0,263 & 0.295 & 0,280 \\
\hline $\mathrm{Cr}$ & 0,000 & 0.003 & 0.000 & 0,004 & 0,000 & $\begin{array}{l}0,602 \\
0,000\end{array}$ & $\begin{array}{l}0,630 \\
0,002\end{array}$ & $\begin{array}{l}0.581 \\
0.000\end{array}$ & $\begin{array}{l}0.647 \\
0.003\end{array}$ & $\begin{array}{l}0,590 \\
0001\end{array}$ & 0.622 & 0.637 & 0.164 & 0,400 & 0,319 & 0.371 & 0,395 & 0,372 & 0,379 \\
\hline Fezt & 2.665 & 2,650 & 2,677 & 2,523 & 2,600 & 3,966 & 3.833 & 3,939 & 3.866 & $\begin{array}{l}0,001 \\
3895\end{array}$ & 0,001 & 0,001 & 0,005 & 0,000 & 0,000 & 0,000 & 0,001 & 0,000 & 0,003 \\
\hline Mn & 0.047 & 0,033 & 0,042 & 0,042 & 0,042 & 0,028 & 0,043 & 0.041 & 0.040 & $\begin{array}{l}3,895 \\
0,048\end{array}$ & $\begin{array}{l}3,928 \\
0,042\end{array}$ & 3.981 & 1,520 & 4,333 & 4,073 & 4,202 & 4,241 & 4,265 & 4,313 \\
\hline $\mathrm{mg}$ & 2.268 & 2,339 & 2,278 & 2,355 & 2.447 & 1,112 & 1.067 & 1.082 & 1,048 & $\begin{array}{l}0,048 \\
1,067\end{array}$ & $\begin{array}{l}0,042 \\
1,074\end{array}$ & $\begin{array}{l}0,031 \\
1,063\end{array}$ & $\begin{array}{l}0,013 \\
3711\end{array}$ & $\begin{array}{l}0,069 \\
0658\end{array}$ & $\begin{array}{l}0,017 \\
0717\end{array}$ & 0.053 & 0.068 & 0,053 & 0,058 \\
\hline Somay & 5,715 & 5.733 & 5.723 & 5,707 & 5.703 & 5,690 & 5.625 & 5,679 & 5,610 & 5.654 & 5,671 & 5,690 & 5,886 & $\frac{0,030}{5.678}$ & $\frac{0,717}{5621}$ & 0,706 & 0,695 & 0.665 & 0.642 \\
\hline $\mathrm{Ca}$ & 0.018 & 0,000 & 0,000 & 0,018 & 0,029 & 0,004 & 0.001 & 0,004 & 0.003 & 0,005 & & & & & 5,621 & 5,626 & 5,664 & 5,661 & 5.676 \\
\hline $\mathrm{Na}$ & 0,004 & 0,022 & 0,000 & 0,000 & 0,040 & 0,000 & 0,000 & 0,000 & 0,000 & 0,005 & 0000 & 0,01 & 0,001 & 0,000 & 0,000 & 0,003 & 0,020 & 0,000 & 0,017 \\
\hline $\mathrm{K}$ & 1,825 & 1,862 & 1,907 & 1.891 & 1,816 & 1.941 & 1.906 & 1,905 & 1972 & 1,922 & 1899 & 0,000 & & 0,000 & 0,000 & 0,000 & 0,000 & 0,000 & 0.000 \\
\hline Somax & 1,846 & 1,884 & 1,907 & 1,909 & 1,885 & 1,945 & 1,908 & 1,909 & $\frac{1,012}{1.975}$ & $\frac{1,022}{1,932}$ & $\frac{1,093}{1,911}$ & $\frac{1,856}{1076}$ & 1,649 & 1,987 & 1,925 & 2,041 & 1.975 & 2,021 & 1,948 \\
\hline Total & 15,561 & 15,616 & 15,630 & 15,616 & 15,587 & 15,635 & 15,533 & $\frac{1,503}{15,588}$ & $\frac{1,510}{15,585}$ & $\frac{932}{15,586}$ & & 1,875 & 1,650 & 1,987 & 1,925 & 2,044 & 1,995 & 2.021 & 1,965 \\
\hline$F$ & 0,27 & 0,00 & 0,00 & 0,00 & 0,05 & 0,13 & 0,09 & $\frac{10,008}{0,55}$ & $\frac{13,030}{0,00}$ & $\frac{10,000}{0,00}$ & $\frac{15,582}{0,14}$ & 15,565 & 15,535 & 15,665 & 15,546 & 15,670 & 15,658 & 15.682 & 15,641 \\
\hline Cl & 0.01 & 0,01 & 0,01 & 0,01 & 0,01 & 0.02 & 0,02 & 0.02 & 0,03 & 0,03 & $\begin{array}{l}0,14 \\
0,01\end{array}$ & 0,00 & 0,06 & 0,15 & 0,02 & 0,43 & 0,05 & 0,00 & 0.31 \\
\hline $\mathrm{Mg \#}$ & 0,46 & 0.47 & 0,46 & 0,47 & 0.48 & 0,22 & 0,22 & 0,22 & 0,21 & 0,22 & 0,21 & 0,0 & 0,01 & 0.09 & 0,10 & 0,07 & 0.08 & 0,08 & 0,09 \\
\hline Alt & 2,759 & 2.767 & 2,805 & 2,711 & 2,546 & 2.496 & 2,521 & 2,505 & 2,508 & 2,532 & 2,520 & $\begin{array}{c}0,21 \\
2,502\end{array}$ & 0.71 & 0,13 & 0,15 & 0.1 & 0.1 & 0,14 & 0,13 \\
\hline & & & & & & & & & & & & 2,502 & 2,700 & 2,579 & 2.797 & 2,628 & 2,660 & 2,677 & 2,654 \\
\hline
\end{tabular}




\begin{tabular}{|c|c|c|c|c|c|c|c|}
\hline & LP4 & IP136 & IP132 & $\overline{\text { IP128 }}$ & IP129 & EP64 & EP63 \\
\hline $\mathrm{SiO} 2$ & 47,880 & 48,627 & 50,353 & 48,840 & 48,438 & 49,502 & 51,828 \\
\hline TiO2 & 0,615 & 0,253 & 0,343 & 0,614 & 0,443 & 0,614 & 0,181 \\
\hline Al2O3 & 35,285 & 36,174 & 35,403 & 36,048 & 36,917 & 35,752 & 34,526 \\
\hline $\mathrm{Cr} 2 \mathrm{O} 3$ & 0,034 & 0,005 & 0,037 & 0,000 & 0,034 & 0,029 & 0 \\
\hline $\mathrm{FeO}$ & 2,506 & 1,456 & 2,163 & 1,822 & 1,728 & 2,337 & 2,571 \\
\hline Mno & 0,015 & 0,000 & 0,004 & 0,000 & 0,007 & 0,045 & 0,014 \\
\hline MgO & 1,361 & 0,897 & 1,557 & 0,926 & 0,848 & 1,319 & 1,677 \\
\hline CaO & 0,025 & 0,029 & 0,005 & 0,048 & 0,050 & 0,015 & 0,046 \\
\hline Na2O & 0,212 & 0,266 & 0,141 & 0,216 & 0,339 & 0,196 & 0,175 \\
\hline K2O & 7,839 & 8,052 & 8,019 & 8,207 & 7,999 & 8,211 & 7,651 \\
\hline$F$ & 1,209 & 0,214 & 0,471 & 0,477 & 0,000 & 0,367 & 0,571 \\
\hline $\mathrm{Cl}$ & 0,000 & 0,027 & 0,001 & 0,002 & 0,008 & 0,021 & \\
\hline $\mathrm{H} 2 \mathrm{O}$ & 0,000 & 0,000 & 0,000 & 0,000 & 0,000 & 0 & 0 \\
\hline Total & 96,981 & 96,000 & 98,497 & 97,200 & 96,811 & 98,408 & 99,240 \\
\hline IO_F_C & 9053 & 0,096198 & , 198429 & 0,201293 & 0,001805 & 0,159265 & 0,240421 \\
\hline Ctotal & & 95,9038 & 807 & 871 & & 98,24873 & 98,99958 \\
\hline Si & 875 & 618742 & 676198 & 625832 & 1,61245 & 1,64787 & 1,7253 \\
\hline 11 & 5398 & 0,006335 & 0,008588 & 0,015373 & 0,011092 & 0,015373 & 0,004532 \\
\hline Al & 1,038201 & 1,064359 & 1,041673 & 1,060651 & 1,08622 & 1,051942 & 1,015869 \\
\hline $\mathrm{Cr} 2 \mathrm{O} 3$ & 0,000671 & 9,87E-05 & 0,00073 & 0 & 0,000671 & 0,000572 & 0 \\
\hline $\mathrm{FeO}$ & 0,034878 & 0,020264 & 0,030104 & 0,025358 & 0,02405 & 0,032526 & 0,035783 \\
\hline no & 0,000211 & 0 & $5,64 \mathrm{E}-05$ & 0 & $9,87 E-05$ & 0,000634 & 0,000197 \\
\hline $\mathrm{MgO}$ & 0,033772 & 0,022258 & 0,038635 & 0,022978 & 0,021042 & 0,03273 & 0,041613 \\
\hline $\mathrm{CaO}$ & 0,000446 & 0,000517 & $8,92 \mathrm{E}-05$ & 0,000856 & 0,000892 & 0,000267 & 0,00082 \\
\hline $\mathrm{Na2O}$ & 0,00342 & 0,004292 & 0,002275 & 0,003485 & 0,00547 & 0,003162 & 0,002823 \\
\hline K2O & 0,083217 & 0,085478 & 0,085127 & 0,087123 & 0,084915 & 0,087166 & 0,081221 \\
\hline$F$ & 0,063632 & 0,011263 & 0,02 & 0,025105 & 0 & 0,019316 & 0,030053 \\
\hline C & 0 & 0,000762 & 1,4 & $5,64 \mathrm{E}-05$ & 0,000226 & 0,000592 & 0 \\
\hline Totala & 1089 & 2,822342 & 2,88 & 2,841657 & 69 & 2,872242 & 8158 \\
\hline Totalb & 2,867721 & 2,834367 & 2,908281 & 2,866818 & 2,847126 & 2,89215 & 2,938211 \\
\hline fatora & 7,845684 & 7,794943 & 7,62 & 7,741963 & 7,7 & 7,659521 & 7,564926 \\
\hline F_CL. & 2,835905 & 2,828355 & 2,89 & 2,854237 & 2,8 & 96 & 2,923184 \\
\hline fator b & 7,757664 & 7,778373 & 7,597002 & 7,707838 & 7,727398 & 7,633068 & 7,526039 \\
\hline 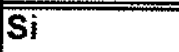 & & & & 826 & $\overline{021}$ & 15 & 492336 \\
\hline & 27 & 11 & 1,63 & 174 & 79 & 85 & ,507664 \\
\hline Somaz & 8 & 8 & 8 & 8 & 8 & 8 & 8 \\
\hline Lay & 3,551717 & 07 & 71 & 6044 & 791 & 179 & 3,589316 \\
\hline$\pi$ & 727 & 0,024636 & 0,03 & 0,059247 & 0,042855 & 58672 & 0,017053 \\
\hline 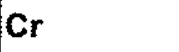 & 471 & 12 & 99 & 0 & 0,003457 & 0,002913 & 0 \\
\hline Fe2t & 573 & 0,157624 & & 195458 & 0,1 & 274 & 0,269303 \\
\hline Mn & 0,00164 & 0 & 0,0 & 0 & 63 & 342 & 0,001485 \\
\hline $\mathrm{Mg}$ & 0,26199 & 132 & 0,2 & 7108 & 01 & 327 & 0,31318 \\
\hline SomaY & 4,149118 & 4,170811 & 4,2 & 147857 & 4,221311 & 6706 & 0338 \\
\hline $\mathrm{Ca}$ & 0,003458 & 0,004022 & &, 006597 & 0,00 & 2042 & 0,006173 \\
\hline $\mathrm{Na}$ & & & & 53724 & 53 & 276 & 0,042499 \\
\hline & 1,291132 & 1,329755 & 1,293426 & 1,343062 & 1,312345 & 1,330682 & 1,222542 \\
\hline & 13,49678 & 13,57135 & & 13,55124 & 08 & 71 & 13,46155 \\
\hline & 0,493632 & 0,087609 & $\overline{0,1}$ & 93507 & 0 & & 0,226177 \\
\hline Cl & 0 & 0,005924 & 0,000107 & 0,000435 & 0,001744 & 0,004522 & \\
\hline hg & 41 & 0,523442 & 0,562052 & 0,475373 & 0,466647 & 0,501559 & 0,537664 \\
\hline Alt & 5,369 & 5, & 29 & 5 & 577 & 229 & 698 \\
\hline $\mathrm{Fe} / \mathrm{Fe}+\mathrm{Mg}$ & 0,508059 & 0,476558 & & 4627 & & & 2336 \\
\hline & 0,96244 & 1,100 & 1,280976 & 0,906117 & 56 & & 1,156549 \\
\hline $\mathrm{AIV} \mid+\mathrm{Cr}+\mathrm{T}$ & 3.614914 & 3,840055 & 3,679091 & 3.775291 & 3.872103 & 3,703764 & 3,606369 \\
\hline
\end{tabular}

Obs: Nesta tabela estão inseridos os cálculos estruturais para mica branca (programa EXCELL) 


\begin{tabular}{|c|c|c|c|c|c|c|c|c|c|c|c|c|c|c|c|c|c|c|c|c|c|c|}
\hline \multirow{2}{*}{$\begin{array}{l}\text { Maciço } \\
\text { Fácies } \\
\text { Analise }\end{array}$} & \multirow{2}{*}{\multicolumn{3}{|c|}{$\begin{array}{l}\text { Waciço Arrozal } \\
\text { Facies qzo-monz. } \\
\text { DP201 DP202 DP203 }\end{array}$}} & \multirow{2}{*}{\multicolumn{2}{|c|}{$\begin{array}{l}\text { Maciço Arrozal } \\
\text { Enclave máfico } \\
\text { JP109 JP110 }\end{array}$}} & \multirow[b]{2}{*}{ JP111 } & \multirow[b]{2}{*}{ JP112 } & \multirow[b]{2}{*}{ JP113 } & \multirow[b]{2}{*}{ JP114 } & \multicolumn{4}{|c|}{ Juaciço Getulandia } & \multicolumn{6}{|c|}{ Dominio Quirmo } & \multicolumn{3}{|c|}{ Rochas basicas } \\
\hline & & & & & & & & & & 968 & P69 & P70 & P71 & P72 & 273 & P74 & P75 & & P77 & 61 & 111 & $11 \mathrm{~A}$ \\
\hline 102 & 40,45 & 40,32 & 40,30 & 47,99 & $5 \overline{3,48}$ & दूर & रग & 52,44 & 525 & गण & 76 & 41,90 & $=41,44$ & 41,40 & 41,56 & 1,31 & 1,29 & 41,36 & 41,42 & 5,10 & 44,96 & 38,5 \\
\hline & & & & & & & & & & & & & & & & & & & & 34 & 1,58 & 1,09 \\
\hline & & 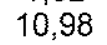 & & & & & & & & & & & & & & & 9,94 & & & & 9,28 & 10,49 \\
\hline & & 27,39 & 26,27 & & & & & & & & & & 19,34 & 26,46 & & & 27,09 & & 26,72 & 18,16 & 18,14 & 30,58 \\
\hline & & & & & & & & & & & & & & & & & & & & & & \\
\hline & & & & & & & & & & & & & & & & & & & & & & \\
\hline & & 4,07 & 2 & & & & & & & & & & & & & & & & & & & \\
\hline & & 11,06 & 11,03 & & & & & & & & & & & & & & & & & & 11,38 & 10,42 \\
\hline & & & 1,2 & & & & & & & & & & & & & & & & & & & 1,49 \\
\hline & & 1, & 1,89 & & & & & & & & & & & & & & & & & & & \\
\hline & & & 0.99 & & & & & & & & & & & & & & & & & & & \\
\hline & & 0,28 & 0,23 & & & & & & & & & & & & & & & & & & & 39 \\
\hline$F c$ & & 0 , & 0,47 & & & & & & & & & & & & & & & & 0,20 & & & 0,25 \\
\hline tal & 3 & 3,8 & 98,97 & & & & & & & & & & & & & & & & & & 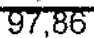 & $\pi$ \\
\hline & & & 6,288 & & & & & & & & & & & & & & & & & & & \\
\hline & & 23 & 1,712 & & & & & & & & & & & & & & & & & & & \\
\hline & 8 & 8,000 & 8,000 & 8 & 8,0 & 0 & 0 & 8 & & & & & 00 & 00 & & & & & & & & \\
\hline & & & 0,294 & & & & & & & & & & & & & & & & & & & \\
\hline & & & 0.1 & & & & & & & & & & & & & & & & & & & \\
\hline & & & 0,0 & & & & & & & & & & & & & & & & & & & \\
\hline & 7 & 63 & 0,634 & & & & & 1 & & & & & 0,6 & & & & & & & & & \\
\hline & & & & & & & & & & & & & & & & & & & & & & \\
\hline & & & & & & & & & & & & & & & & & & & & & & \\
\hline & & & 1.027 & & & & & & & & & & & & & & & & & & & \\
\hline & & 5 & 5,000 & 5,0 & & 5,000 & 5,000 & 5,0 & 5,0 & & 5 & 0 & 5,000 & 5,000 & 0 &, 000 & 000 & 5,000 & 5,000 & & & 000 \\
\hline & & 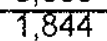 & 1,844 & & & 1,786 & & 1,7 & & & & & & 1,710 & & & & 1,722 & 1,712 & & & \\
\hline & & & 0.1 & & & & & & & & & & & & & & & & & & & \\
\hline & & & & & & & & & & & & & & & & & & & & & & \\
\hline & & & & & & & & & & & & & & & & & 128 & 0,111 & 0,122 & & & 6 \\
\hline I & & 363 & 0,3 & & & & & 0, & & & & & & & & & & & & & & \\
\hline & & & & & & & & & & & & & & & & & & & & & & \\
\hline & & & & & & & & & & & & & & & & & & & & & & \\
\hline & & & & & & & & & & & & & & & & & & & 0 & & 0,09 & 0,21 \\
\hline & & & & & & & & & & & & & & & & & & & & & & 0,11 \\
\hline & 0,28 & 0,25 & 0,27 & 0 & 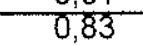 & 0,8 & 0,88 & 0, & 0,87 & o, & 0 & & 0 & & & & & 0 & & & & $\pi 12$ \\
\hline & & & 2,006 & & & & & & & & & & & & & & & & & & & \\
\hline 11030 & & & & - & 4 & & & & & & & & & & & & & e-1s & & & & \\
\hline
\end{tabular}




\begin{tabular}{|c|c|c|c|c|c|c|c|c|c|c|c|c|c|c|c|c|c|c|c|c|c|c|c|c|c|c|c|c|c|c|}
\hline Actiabs & & $\mathrm{SiO}$ & 12037 & 203 & Mno & $\mathrm{MgO}$ & $\mathrm{CaOA}$ & $\sqrt{220}$ & K2O & T102 F & 205 & LOI & TOTAL & $8 a$ & Sr & $\mathbf{Y}$ & $\mathrm{Zr}$ & Be & $\mathbf{v}$ & $\mathrm{Nb}$ & $\mathbf{R b}$ & $\mathbf{P b}$ & $\mathbf{G a}$ & $5 n$ & 5 & \multirow{2}{*}{\multicolumn{5}{|c|}{$\begin{array}{l}\text { \$. Classificação de campo } \\
\text { oranito foliado }\end{array}$}} \\
\hline AMSVR-27 & MVR27 & 70,12 & 13,62 & 3,73 & 0,04 & 1,41 & 2,21 & 2,76 & 3,65 & 0,538 & 0,07 & 1,09 & 99,23 & 921 & 243 & 3 & 334 & 2 & 62 & 9 & 142 & 11 & $18<$ & \multirow{2}{*}{\multicolumn{2}{|c|}{$<50$}} & & & & & \\
\hline MANGA-PI-38 & MVR38 & 75,58 & 13,29 & 1,17 & 0,01 & 0,34 & 1,29 & 3,69 & 4,33 & 0,135 & 0,07 & 0,84 & 100,74 & 598 & 184 & 15 & 124 & 2 & 7 & 9 & 163 & 23 & $21<$ & 5 & & \\
\hline VR@-229 & MVR229 & 70,41 & 13,80 & 4,32 & 0,06 & 3,64 & 2,06 & 2,16 & 4,81 & 0,477 & 0,04 & 0,86 & 100,62 & 983 & 219 & 6 & 325 & 2 & 73 & 17 & 194 & 28 & & & 600 & \multicolumn{5}{|c|}{ blastomilonito } \\
\hline VR@-204 & QVR204 & 58,76 & 15,76 & 10,41 & 0,23 & 1.05 & 3,76 & 3,77 & 4,79 & 1,132 & 0,42 & 0,79 & 100,87 & 2529 & 327 & 51 & 672 & 2 & 10 & 37 & 100 & 14 & 21 & & 9 & \multicolumn{5}{|c|}{5 granodiorito } \\
\hline VR@-200 & QVR200 & 63,62 & 16,42 & 6,43 & 0,10 & 2,07 & 0,44 & 2,05 & 6,40 & 0,774 & 0,06 & 1,36 & 99,72 & 547 & 72 & 25 & 227 & 2 & 93 & 26 & 320 & 7 & & $<5$ & $<50$ & \multirow{2}{*}{\multicolumn{5}{|c|}{ granodiorito }} \\
\hline MAVR-106 & QVR306 & 61,15 & 17,30 & 2,56 & 0,03 & 1,00 & 3,04 & 2,18 & 9,83 & 0,444 & 2,17 & 0,76 & 100,45 & 1556 & 313 & 199 & 120 & -1 & 28 & 19 & 342 & 34 & & $<5$ & $<50$ & & & & & \\
\hline AN-199 & QVR199 & 69,60 & 16,48 & 1,72 & 0,02 & 1,06 & 2,03 & 3,06 & 6,11 & 0,275 & 0,08 & 0,47 & 100,91 & 1092 & 267 & 8 & 226 & 4 & 22 & 9 & 171 & 33 & $18<$ & $=5$ & $<50$ & & & & & \\
\hline VR@-224A & BVR224A & 61,48 & 15,71 & 7,30 & 0,11 & 2,20 & 4,53 & 2,56 & 3,40 & 1,638 & 0,51 & 1,11 & 100,55 & 1248 & 357 & 34 & 443 & 2 & 110 & 25 & 127 & 11 & $17<$ & 5 & & \multicolumn{5}{|c|}{30 enclave no granito } \\
\hline ARVR:111 & BVR\{1\} & 47,38 & 15,30 & 16,91 & 0,26 & 7,63 & 6,73 & 3,18 & 0,84 & 1,309 & 0,85 & $-0,15$ & 100,23 & 468 & 532 & 33 & 153 & 1 & 76 & 7 & $16<$ & & & & & \multirow{2}{*}{\multicolumn{5}{|c|}{\begin{tabular}{l|l}
0 & diorito follado \\
5 & Contato entre FK granito e diorito
\end{tabular}}} \\
\hline ARVR-112A & BVR112A & 60,32 & 18,92 & 6,24 & 0,05 & 0,68 & 3,30 & 4,55 & 4,55 & 1,131 & 0,32 & 0,51 & 100,58 & 1744 & 567 & 23 & 1933 & 2 & 218 & 6 & 75 & 20 & 20 & & 325 & & & & & \\
\hline ARVR-112B & BVR112B & 55,66 & 14,45 & 10,15 & 0,19 & 2,72 & 5,43 & 3,44 & 3,01 & 2,304 & 0,78 & 0,70 & 98,82 & 844 & 339 & 47 & 412 & 3 & 153 & 29 & 104 & 11 & & $<5$ & 790 & diorito fc & aliado & & & \\
\hline MAVR70B & BVR7OB & 48,83 & 14,83 & 10,41 & 0,19 & 8,33 & 12,17 & 1,16 & 0,56 & 0,866 & 0,07 & 1,30 & 98,73 & 146 & 86 & 23 & 71 & 2 & 256 & 4 & 38 & 11 & & $\leqslant 5$ & 38 & granito & porfiritico & & & \\
\hline MAVR-72 & BVR72 & 52,06 & 13,01 & 13,89 & 0,21 & 3,92 & 7,07 & 2,89 & 1,85 & 3,594 & 0,76 & 1,63 & 100,88 & 714 & 658 & 43 & 333 & 3 & 363 & 30 & 53 & 6 & & 5 & 710 & rocha be & isica & & & \\
\hline VRe-220 & BVR220 & 51,74 & 14,46 & 12,09 & 0,21 & 5,22 & 8,91 & 3,28 & 1,29 & 2,392 & 0,41 & 0,68 & 100,67 & 768 & 447 & 45 & 106 & 1 & 193 & 12 & 38 & 6 & $18<$ & $<5$ & 940 & granodic & & & & \\
\hline pl-11-36 & GVR36 & 71,90 & 14,61 & 2,45 & 0,07 & 0,72 & 1,45 & 3,17 & 4,55 & 0,276 & 0,16 & 1,06 & 100,40 & 784 & 189 & 34 & 202 & 3 & 1 & 13 & 214 & 30 & $20<$ & $<5$ & $<50$ & granito & gnaisse & & & \\
\hline MAVR-13 & GVR13 & 68,14 & 14,76 & 4,44 & 0,07 & 1,09 & 2,43 & 2,72 & 4,61 & 0,916 & 0,35 & 0,90 & 100,43 & 874 & 195 & 31 & 391 & 2 & 46 & 21 & 212 & 20 & $19<$ & $<5$ & $<50$ & & & & & \\
\hline MAVR-22 & GVR22 & 62,90 & 16,21 & 6,18 & 0,09 & 2,23 & 3,91 & 2,89 & 2,34 & 1,195 & 0,39 & 0,84 & 99,16 & 977 & 255 & 27 & 331 & 2 & 85 & 19 & 178 & 10 & $19<$ & 5 & 0 & granito & evements & e foliado & porfiritico & \\
\hline MAVR-39 & GVR39 & 67,10 & 14,75 & 4,89 & 0,06 & 1,43 & 2,41 & 2,51 & 4,31 & 0,967 & 0,37 & 1,01 & 99,81 & 854 & 19 & 26 & 360 & 2 & 61 & 23 & 220 & 18 & 20 & $<5$ & $<50$ & granito & Dorfinitico & & & \\
\hline MAVR:42 & GVR42 & 67,61 & 14,80 & 4,60 & 0,08 & 1,38 & 2,77 & 2,39 & 4,44 & 0,918 & 0,35 & 1,10 & 100,43 & 1017 & 225 & 42 & 387 & 2 & 57 & 21 & 196 & 20 & $20<$ & $<5$ & $<50$ & granito & corfinitico & & & \\
\hline MAVR-46 & GVR46 & 68,39 & 15,17 & 4,18 & 0,05 & $1_{r}, 32$ & 2,82 & 2,85 & 3,11 & 0,821 & 0,34 & 1,30 & 100,34 & 952 & 249 & 26 & 367 & 1 & 61 & 20 & 186 & 14 & $21<$ & $<5$ & $<50$ & anito & oorfiritico & & & \\
\hline MAVR-49 & GVR49 & 63,97 & 15,42 & 5,61 & 0,10 & 1,67 & 3,00 & 2,53 & 4,19 & 1,190 & 0,40 & 1,27 & 99,34 & 1044 & 248 & 38 & 441 & 2 & 75 & 22 & 173 & 22 & 210 & $=5$ & $<50$ & granito & oorfiritico & & & \\
\hline RAVR-14 & GVR14 & 66,38 & 15,18 & 5,90 & 0,08 & 1,37 & 2,65 & 2,56 & 4,72 & 1,112 & 0,43 & 0,61 & 100,99 & 976 & 226 & 35 & 511 & 2 & 62 & 27 & 221 & 22 & $20<$ & $<5$ & $<50$ & granito & corfiritico & & & \\
\hline RJAR-1 & GVR1 & 68,84 & 13,99 & 4,58 & 0,11 & 1,65 & 1,65 & 2,17 & 3,85 & 0,543 & 0,08 & 1,18 & 98,63 & 72 & 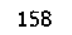 & 32 & 19 & 4 & 63 & 21 & 195 & 26 & $22<$ & $<5$ & $<50$ & granto & fino home & ogêneo & & \\
\hline$A N-181$ & GVR\}B1 & 67,74 & 14,81 & 4,43 & 0,06 & 1,28 & 2,57 & 2,64 & 4,62 & 0,901 & 0,38 & 1,05 & 100,49 & 951 & 232 & 45 & 430 & 2 & 55 & 19 & 21 & 31 & 17 & & $<50$ & & & & & \\
\hline VR@-219 & GVR219 & 65,07 & 15,72 & 5,28 & 0,12 & 1,80 & 3,85 & 3,45 & 3,81 & 0,718 & 0,39 & 0,59 & 100,80 & 983 & 365 & 38 & 230 & 5 & 82 & 24 & 165 & 27 & $20<$ & $<5$ & $<50$ & nito & porfiritico & & & \\
\hline VR@-222A & GVR224A & 65,96 & 15,77 & 4,39 & 0,08 & 1,74 & 2,67 & 3,82 & 3,46 & 0,570 & 0,24 & 0,82 & 100,54 & 604 & 303 & 40 & 177 & 5 & 62 & 23 & 261 & 16 & 23 & & $15<50$ & granito & aisse & & & \\
\hline VRe. -225 & GVR225 & 67,57 & 15,14 & 4,77 & 0,07 & 1,21 & 2,16 & 2,37 & 4,80 & 1,076 & 0,43 & 0,76 & 100,36 & 95 & 18 & 32 & 529 & 1 & 53 & 22 & 233 & 30 & $20<$ & $<5$ & $<50$ & granito & Fliado Ar & rozai & & \\
\hline VR@.226 & GVR226 & 68,90 & 14,71 & 4,09 & 0,06 & 1,92 & 2,22 & 3,04 & 3,57 & 0,422 & 0,15 & 0,91 & 99,99 & 777 & 276 & 18 & 16 & 2 & 53 & 15 & 156 & 18 & $19<$ & $<5$ & 70 & granito & porfiritico & & & \\
\hline MAVR-61 & LVR61 & 51,00 & 18,35 & 5,40 & 0,13 & 2,65 & 17,74 & 1,78 & 0,30 & 0,684 & 0,11 & 2,40 & 100,53 & 126 & 791 & 41 & 159 & 14 & 66 & 21 & 29 & 7 & 28 & 18 & 85 & & to + ler & tes bảsic & & \\
\hline PI:-11-47 & LVR47 & 63,59 & 15,99 & 5,46 & 0,08 & 2,21 & 3,53 & 3,55 & 4,23 & 1,020 & 0, & 0,76 & 100,86 & 2005 & 787 & 26 & 379 & 3 & 94 & 16 & 151 & 18 & 16 & & 170 & leucogr & & & & \\
\hline VR@-227 & LVR227 & 63,24 & 15,46 & 6,26 & 0,11 & 1,15 & 3,19 & 3,50 & 4,58 & 0,951 & 0,38 & 0,60 & 99,42 & 130 & & 60 & 899 & 3 & $5 i$ & 30 & 136 & 15 & $21<$ & $<5$ & 125 & leucogr & Inito & & & \\
\hline VR@-221 & GPR221 & 70,80 & 14,25 & 3,86 & 0,05 & 1,12 & 1,98 & 2,39 & 4,32 & 0,709 & 0,26 & 1,11 & 100,84 & 89 & 172 & 33 & 31 & 2 & 4. & 22 & 252 & 27 & $24<$ & $<5$ & 130 & grat & offiritico & & & \\
\hline VR@-222 & GPR222 & 75,26 & 13,56 & 1,69 & 0,02 & 0,19 & 0,56 & 2,75 & 5,67 & 0,204 & 0,08 & 0,83 & 100,82 & 430 & 94 & 40 & 217 & 3 & 10 & 20 & 327 & 29 & 17 & & $5<50$ & fK $g$ & Getulâ & in & & \\
\hline VR@.215 & GPR215 & 71,72 & 15,20 & 2,71 & 0,05 & 0,89 & 2,23 & 3,24 & 4,00 & 0, & 0,1 & 0,47 & 101,00 & 1822 & 486 & 10 & 220 & 1 & 35 & 8 & 93 & 20 & $13<$ & $<5$ & $<50$ & granito & & & & \\
\hline VR@-224 & GPR224 & 73,35 & 14,31 & 2,59 & 0,06 & 0,56 & 1,49 & 3,51 & 3,95 & 0,273 & 0,09 & 0,55 & 100,73 & 717 & 145 & 18 & 199 & 2 & 13 & 10 & 169 & 20 & $24<$ & $<5$ & $<50$ & granito & sorfiritico & & & \\
\hline & & & $\%$ & $\%$ & $\%$ & $\%$ & $\%$ & $\%$ & $\%$ & $\%$ & $\%$ & $\%$ & $\%$ & $\mathrm{ppm}$ & $\mathrm{ppm}$ & $\mathrm{ppm}$ & $\mathrm{ppm}$ & & $\ldots$ & & & & & 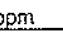 & m & & & & & \\
\hline Saint Etienne & & $\mathrm{SiO} 2$ & $\mathrm{~A}\{2 \mathrm{O} 3$ & $\mathrm{Fe} 203$ & MnO & $\mathrm{MgO}$ & $\mathrm{CaO}$ & $\mathrm{Na} 2 \mathrm{O}$ & $\mathrm{K} 2 \mathrm{O}$ & $\mathrm{TiO2}$ & $\mathrm{P2O5}$ & Total & $\mathrm{Ba}$ & $s r$ & $Y$ & $\mathrm{zr}$ & $\mathrm{Nb}$ & $\mathrm{Rb}$ & $\mathrm{Pb}$ & $\mathrm{Ga}$ & $T h$ & 0 & $Z n$ & $\mathrm{Ni}$ & $\mathrm{Hf}$ & $\mathrm{Pf}$ & $w$ & $\mathrm{Cs}$ & $\mathrm{Ce}$ & $\mathrm{La}$ \\
\hline RAVR.59 & GVR59 & 68,47 & 15,22 & 4,67 & 0,063 & 1,27 & 2,44 & 2,65 & 5,01 & 0,959 & 0,326 & 101,73 & 931,7 & 198,2 & 38,2 & 287,3 & 36,2 & 228,3 & 45,2 & 32,0 & $55,8,4$ & $4<3,0$ & 81,5 & 19,9 & 15,3 & 0,65 & 23,7 & 6,6 & 167,2 & 68,5 \\
\hline MAVR.98 & $\mathrm{G}$ & 6 & 14,88 & 5,41 & 0,134 & 1,59 & 2,41 & 3,14 & 3,08 & 0,571 & 0,020 & 101,43 & 593,1 & 252,4 & 60,1 & 211,2 & 38 & 18 & 39,4 & 30 & 38,723 & $3<3,0$ & 59,6 & 31,6 & 14,4 & 0,90 & 24,1 & 8,7 & 117,7 & 49,0 \\
\hline MAVR.99 & GVR99 & 69,90 & 14,90 & 4,4 & 0,070 & 1,40 & 2,36 & 2,48 & 4,46 & 0,944 & 0,273 & 101,64 & 720,7 & 193,4 & 25,4 & 269,6 & 37,7 & 239,7 & 41,2 & 30,9 & $36,9,4$ & $4<3,0$ & 86,6 & 22,4 & 16,1 & 0,41 & 24,5 & 7,0 & 148,8 & 62,1 \\
\hline RAVR.101 & GVR101 & 73,78 & 14,93 & 1,40 & 0,023 & 0,48 & 1,48 & 3,48 & 5,02 & 0,224 & 0,071 & 101,40 & 563,0 & 203,5 & 9,5 & 128,4 & 26,3 & 258,3 & 58,1 & 31,3 & 32,1 & 28,1 & 50,9 & 13,8 & 14,2 & 0,51 & 24,5 & 15,1 & 73,0 & 31,5 \\
\hline RAVR.102 & GVR102 & 68,95 & 15,01 & 4,66 & 0,074 & 1,20 & 2,46 & 2,73 & 4,99 & 0,931 & 0,356 & 102,09 & 798,4 & 195,4 & 32,2 & 288,1 & 34,4 & 228,2 & 45,1 & 30,6 & $58,5,4$ & $4<3,0$ & 82,3 & 17,6 & 12,9 & 0,73 & 17,4 & 8,7 & 171,9 & 72,7 \\
\hline RAVR.103 & GVR103 & 68,28 & 15,20 & 4,94 & 0,078 & 1,50 & 2,65 & 2,39 & 4,79 & 0,990 & 0,335 & 101,82 & 942,3 & 225,8 & 46,3 & 297,4 & 32 & 205,5 & 43,8 & 30,8 & $52,8,7$ & $7<3,0$ & 84,2 & 22,9 & 15,2 & 0,66 & 21,7 & 6,4 & 176,6 & 112,0 \\
\hline Q.104 & GVR10 & 67,76 & 15,7 & 5,2 & 0,055 & 1,62 & 2,90 & 3,08 & 3,36 & 0,921 & 0,268 & 101,52 & 654,3 & 208,4 & 25,7 & 266,2 & 35,4 & 188,2 & 37,3 & 3 & & & 90,1 & 16,9 & 15,1 & 0,58 & 16,5 & 11,8 & 118,5 & 55,4 \\
\hline MAVR,106 & GVR106 & 72,61 & 15,38 & 2,23 & 0,013 & 1,0 & 2 & 3, & 4,44 & 0,370 & 0,114 & 102,63 & 638,1 & 255,7 & 13,3 & 140,7 & 28,4 & 190,6 & 42,7 & 30,8 & $27,3,9$ & $9<3,0$ & 66,3 & 28,0 & 13,1 & 0,97 & 21,0 & i & 68,2 & 25,9 \\
\hline MAVR.110b & GVR110B & 66,80 & 15,82 & 5,04 & 0,073 & 1,94 & 2,68 & 2,27 & 5,44 & 1,035 & 0,416 & 102,23 & 1301,6 & 216 & 45,8 & 359,6 & 33,7 & 196,0 & 50,0 & 31,3 & $39,1,6$ & $6<3,0$ & 77,3 & 21,1 & 17,9 & 0,71 & 21,1 & 14,8 & 152,4 & 67,4 \\
\hline MAV & LVR101 & 70,15 & 15,14 & 3,96 & 0,061 & 1,19 & 2,34 & 2,44 & 5,30 & 0,848 & 0,328 & 102,16 & 719,0 & 185,9 & 32,1 & 295,2 & 37 & 260,4 & 45 & 31,1 & $51,6,2$ & $2<3,0$ & 76,9 & 21,5 & 16,3 & 0,40 & 23,5 & 11,0 & 183,6 & 78,8 \\
\hline MAVR.105a & LVR105 & 74,33 & 13, & 2,13 & 0,026 & 0,73 & 1,40 & 2,49 & 5,51 & 0,237 & 0,035 & 101,13 & 659,4 & 178,7 & 15,2 & 373,6 & 25,3 & 155,7 & 45 & 28 & $29,0,9$ & $9<3,0$ & 41,1 & 12,4 & 12,2 & 0.40 & 24,1 & 12,7 & 68,7 & 26,5 \\
\hline MAVR.01 & BVROA & 51,33 & 13,96 & 14,41 & 0,187 & 4,24 & 7,85 & 2,84 & 1,95 & 4,001 & 0,633 & 101,82 & 605,2 & 660,9 & 41,0 & 254,0 & 35,5 & 59,7 & 27,6 & 39,2 & $22,8,6$ & $6<3,0$ & 102,7 & 42,6 & 13,6 & 0,42 & 21,2 & $<5,0$ & 103,5 & 40,7 \\
\hline MAVR.105b & BVR1058 & 60,79 & 16,54 & 7,73 & 0,137 & 2,64 & 4,90 & 2,70 & 3,11 & 1,708 & 0,464 & 101,41 & 1240,2 & 363,8 & 38,2 & 298,4 & 33,9 & 131,6 & 32,0 & 31,3 & $31,8,6$ & $6<3,0$ & 95,1 & 18,7 & 18,8 & 0,69 & 18,2 & $<5,0$ & 162,7 & 75,3 \\
\hline
\end{tabular}




\section{GAPITULO 5 \\ Modelamento dinâmico da Suite Intrusiva Arrozal}

Este capítulo discute o modelo dinâmico de colocação dos maciços graníticos que integram a Sufte Intrusiva Arrozal com base em dados geológicos-estruturais, petrográficos, geoquímicos, de química mineral e gravimétricos, obtidos nos citados maciços e rochas encaixantes

5.1 Consideraçöes preliminares. .113 Introduçăo.

5.1.1. Análise dos modelos tectónicos existentes sobre a cinemática de alojamento de granitos no Rio de Janeiro. 113

5.1.2. Caracteristica e distribuiçăo dos granitóides. 115

5.1.3 Suite Intrusiva Arrozal.

5.2. Análise $\theta$ interpretaçąo de imagem LANDSAT. 116

5.3. Gravimetria do Maciço Granítico Arrozal. 117 Introduçăo.

5.3.1. A importância $\theta$ aplicaçăo do método. 118

5.3.2. Reduçăo dos dados gravimétricos.

5.4. Gravimetria da regiăo de Arrozal.

5.5. Modelo de Alojamento da Suite Intrusiva Arrozal 126

5.6. Consideraçöes finais. 130 


\subsection{Consideraçōes Preliminares}

\section{Introduçäo}

Os estudos sobre a tectônica da litosfera continental envolvem atualmente a caracterização de movimentos e direção dos tensores de esforços, com base na análise do campo vetorial dos deslocamentos e do mecanismos deformacionais que estão intimamente relacionados aos processos de natureza orogênica.

Os métodos de quantificação da deformação são aplicáveis mais adequadamente para regiões da crosta onde a intensidade da deformação foi moderada, ou seja, nas suas porções superiores, limitando-se nos seus resultados quando tais métodos são aplicados às regiões mais profundas da crosta, como é o caso do estudo aqui proposto.

\subsubsection{Análise dos modelos tectônicos existentes sobre a cinemática de alojamento de granitos no Rio de Janeiro}

Nos últimos anos têm sido propostos vários modelos de evolução tectônica para a porção central da Faixa Ribeira no Rio de Janeiro. Estes modelos podem ser agrupados em quatro modelos principais: (1) subduç̧ão para NW, com formação um arco magmático do tipo Cordilherano (Machado \& Demange 1989), ou subducção para SE, com formação de um arco magmático de mesma natureza (Tupinambá 1999); (2) transcorrência destral, com acreção lateral, baseado em grandes deslocamentos horizontais ao longo de zonas de cisalhamento subverticais (Vauchez et al. 1992); (3) transpressão destral com estrutura em-flor positiva, associada a deslocamentos horizontais em grande escala, com empurrões centrífugos a partir da Zona de Cisalhamento de Além-Paraiba - ZCAP (Ebert et al. 1993; Machado \& Endo 1993) e, (4) colagens sucessivas de terrenos para SE (Heilbron 1995).

Analisando-se as hipótese abordadas anteriormente, têm-se que considerar as seguintes premissas: existe uma marcante diferença de nivel crustal atualmente exposto entre as partes norte e sudeste da Faixa Ribeira, particularmente a sul e norte da ZCAP, onde na sua porção NE afloram rochas granuliticas e gnaisses kinzigíticos de grau metamórfico elevado e na porção $S E$, tem-se rochas de grau metamórfico menos elevados com a mesma de direção preferencial predominantemente NE-SW. 
A porção NE do sistema, a litosfera deformável da margem brasileira é comprimida contra a litosfera rígida do Cráton do São Francisco, resultando em tectônica preferencial do tipo sistemas de nappes com direção NW, identificados principalmente no SW do cráton (neste caso específico dentro do Domínio Andrelândia).

Próximo ao cráton, a tectônica tangencial é marcante, mas que poderia representar apenas uma atividade mais precoce da evolução tectônica maior.

Salientanse que ocorre uma importante inflexão progressiva da Faixa Ribeira a partir do paralelo $20^{\circ}$, que modifica o trend norte-sul, para NE-SW, próximo ao paralelo $21^{\circ}$, nas imediações de Juiz de Fora. Esta inflexão, associada a pequenas indentações da possível margem continental, é aqui considerada como importante elemento geométrico para a modelagem tectônica (análise da Imagem LANDSAT 5 - TM3 APÊNDICE 3).

$\mathrm{Na}$ porção SW da Faixa Ribeira afloram metassedimentos, policíclicos prébrasilianos que foram reativados em $600 \mathrm{Ma}$., excluindo, neste caso, os granitóides e bacias menores como Eleutério e Pouso Alegre. Esta porção pode estar associada ao fechamento de um provável mar interior, cujos vestígios estariam próximos à margem continental brasileira atual e possivelmente representados por corpos de rochas básicas deformadas.

Dos modelos propostos pode-se chegar às seguintes considerações em termos de caracterização geral:

No modelo de subducção com colisão obliqua é necessário a caracterização da zona principal, que mergulharia moderadamente para o continente (Cráton de São Francisco), com faixas subsidiárias subverticais. Neste caso, é ainda necessário definir esta zona principal de colisão ao longo do cinturão, pois os mergulhos predominantes das estruturas são divergentes em relação às zonas de maior deformação.

Toda a zona possui o mesmo sentido de movimentação, com o fluxo na zona principal (Além-Paraíba) paralelo ao cinturão. São expostas também estruturas e associações litológicas que sugerem inversões tectônicas, ocorrendo pequenas faixas com movimentos opostos à cinemática dominante, ou ainda, com complexidades litoestruturais resultantes de mudanças reológicas abruptas e distintas.

A análise dos dados obtidos pelos estudos gravimétricos e estruturais da porção sudoeste do Lineamento Além-Paraíba, no Estado do Rio de Janeiro, onde se insere presente trabalho, sugere que a Zona de Cisalhamento de Além-Paraíba (localmente denominada Zona de Cisalhamento de Mendes) e Zona de Cisalhamento de Arrozal 
(ZCA) são as megaestruturas que condicionam o alojamento do magmatismo granítico local representado pela Suite Intrusiva Arrozal. Sugerem também que o fluxo de magma ocorreu no sentido SW, ao longo do Domínio Arrozal, onde a ZCA representa o seu sítio de alojamento local.

Entre o MGA e MGG ocorre uma zona de cisalhamento de segunda ordem, que localmente intercepta as rochas graníticas na sua porção SW. Este aspecto pode ser melhor visualizado no mapa estrutural e na imagem de satélite, em escala 1:250.000 (APÊNDICE 3).

Nesta região são evidenciados indicios de espessamento crustal e soerguimento variável (obtidos a partir de dados gravimétricos), metamorfismo de média pressão e baixa temperatura simultâneos com o movimento transcorrente principal na zona de colisão, aqui representada por uma suposta região de sutura, ao longo da ZCAP.

Utilizando-se os conceitos do modelo de tectônica de escape, podem ser incorporados alguns elementos para análise, como a existência de diversas zonas de cisalhamento sub paralelas que marcam os limites de blocos, incluindo reativações acentuadas de falhas, zonas de falhas divergentes em relação a zonas de intensa deformação, grande espessamento crustal e soerguimentos expondo rochas granulíticas.

\subsubsection{Características e distribuiçäo dos granitóides}

Os granitóides Neoproterozóicoss do Cinturão Paraíba do Sul, no Estado do Rio de Janeiro (Machado \& Demange 1998)(Figura 1.1b - Cap.1) são divididos em três grupos principais: (i) pré- a colisionais, (ii) tardi-colisionais e (iii) pós-colisionais.

Os granitóides pré- a colisionais caracterizam-se por extensos batólitos lineares, foliados, concordantes com as estruturas regionais, sendo possivel distinguir dois grupos de granitóides: um do tipo-l e outro do tipo-S. O primeiro grupo predomina amplamente em relação ao último, e corresponde a um magmatismo de composição expandida (granito / granodiorito / tonalito) com características petrográficas e geoquímicas comparáveis aos batólitos do tipo-l Cordilherano (Machado \& Demange 1984a, 1998; Machado 1997).

Este grupo, no Domínio Litorâneo, encontra-se associado com charnockitos ou rochas da associação charnockítica. O segundo grupo ocorre na extremidade sul dos 
domínios Juiz de Fora e Paraíba Sul, sendo representado pelos maciços Rio Turvo e Serra das Araras.

Os granitos tardi-colisionais ocupam sobretudo o Domínio Paraiba (Norte e Sul) e acham-se ligados estreitamente às zonas de cisalhamento de alto ângulo do vale do rio Paraíba do Sul. É a este grupo de granitos que se associa o Maciço Granítico Arrozal. Destacam-se ainda os Maciços Graníticos Getulândia, Resende, Vassouras, Varre-Sai, Parati, dentre outros. Caracterizam-se por maciços alongados, foliados e de alto ângulo, concordantes com as estruturas das rochas encaixantes (Machado \& Demange 1994a).

Os granitos pós-colisionais ocorrem principalmente na parte sul dos Domínios Litorâneo e Serra dos Órgãos. A distribuição E-W dos maciços sugere uma desvinculação das estruturas NE do cinturão durante a colocação dos mesmos. Alguns autores têm relacionado esta colocação a uma tectônica extensional (p.ex. Machado 1997).

\subsubsection{Suite Intrusiva Arrozal}

A Suíte Intrusiva Arrozal (SIA) está situada no Domínio de Arrozal. Este domínio inclui os granitos Fortaleza, Getulândia e Arrozal, considerados como pertencentes a mesma fonte magmática e alojados durante o mesmo evento deformational, descrito na literatura como sin-F3 (Machado \& Demange 1994a, Machado 1997). Predominam rochas bandadas com texturas miloníticas e protomiloníticas nas porções norte e sul do maciço Arrozal. A intensidade da deformação aumenta em direção às zonas de cisalhamento dúcteis.

Em termos regionais, a SIA associa-se ao prolongamento para sudoeste da Zona de Cisalhamento de Além-Paraíba (localmente denominada ZCMendes). Nesta porção, esta zona de cisalhamento desenvolveu-se em nível crustal médio / inferior, compatível com o metamorfismo de fácies anfibolito a granulito.

\subsection{Análise e interpretaçäo de imagem LANDSAT 5, TM3}

Uma methor visualização dos principais lineamentos em escala regional pode ser feita no cartograma digital, obtido a partir de modelagem e filtragem de imagem de satélite, no programa ENVI 3.2 (Environmental for Visualization), com apoio e colaboração com a DIGEOP - CPRM do Rio de Janeiro. Nesta imagem pode ser observado o forte traço linear da Zona de Cisalhamento de Além-Paraíba na região estudada, com destaque para sua acentuada inflexão de NE/SW para ENE-WSW próximo à Rodovia Presidente Dutra. 


\subsection{Gravimetria do Maciço Granitico Arrozal}

\section{Introduçäo}

A Gravimetria foi utilizada como ferramenta com o objetivo de caracterizar as estruturas geológicas e tectônicas em profundidade, visando principalmente conhecer a geometria em 3D do Maciço Granítico Arrozal (MGA), bem como testar suas relações com as duas zonas de cisalhamento que limitam o maciço a NW e SE, respectivamente.

Esta metodologia, relativamente barata e de fácil execução, busca em última análise medir e comparar variações de pequena magnitude entre O MGA e o campo estacionário (campo gravimétrico terrestre).

A maioria das medições do campo gravimétrico foram distribuídas ao longo da área de ocorrência do MGA e de suas adjacências, buscando assim caracterizar também as rochas encaixantes para comparar os resultados entre os dois dominios.

O campo gravitacional é obtido a partir de funções potenciais harmônicas, que permitem a aplicação de técnicas de filtragem e de realces entre semelhantes.

O método gravimétrico mede a variação da componente vertical da aceleração da gravidade, que, após as devidas correções (Grant \& West 1965), registra informações sobre a distribuição de massas em sub superfície.

A anomalia gravimétrica em superfície, imediatamente acima onde ela está situada, corresponde ao valor gerado através da colocação lateral de rochas com diferentes densidades, sendo possível detectá-la graças ao contraste de densidade entre elas, bem como estimar suas dimensões.

A inexistência de trabalhos envolvendo metodologias integradas com mapeamento geológico-estrutural sistemático e faciológico em escala de detalhe ou semi-detalhe em maciços graníticos associados às zonas de cisalhamento no Estado do Rio de Janeiro, com o apoio de dados gravimétricos, justifica-se por si só a realização do presente trabalho. Além disso, a região é muito favorável, pois combina a existência de excelentes exposições de rochas graníticas com moderadas oscilações de relêvo, tão importantes para eficácia na utilização desta metodologia.

O levantamento gravimétrico em escala de semi-detalhe, juntamente com um levantamento estrutural, constitui-se numa ferramenta indispensável para a modelagem estrutural e tectônica em três dimensões de corpos graníticos, permitindo ao final com o apoio do quadro geológico regional avaliar de forma mais apropriada a modelagem 
dinâmica da ascensão e colocação de magmas graníticos, especialmente quando associados à zonas de cisalhamento (Zona de Cisalhamento de Além-Paraíba), como o exemplo aqui estudado.

\subsubsection{A Importância da aplicaçäo do método}

A partir de relações de campo descontínuas, o tamanho e forma de um determinado pluton podem ser determinados através do uso de métodos geofísicos, principalmente a gravimetria, a qual permite definir a continuidade de um pluton em sub superfície, incluindo seu raio total e a profundidade com o embasamento.

Além disso, permite determinar variações espaciais de densidade das anomalias do campo gravitacional, indicar zonamento geoquímico em profundidade, definir apófises encobertas ou plutons não aflorantes, podendo mesmo dar informações sobre zonamento metamórfico (Vigneresse 1990).

Para estabelecer a "evolução tectônica" dos granitos posicionados sintectônicamente ao longo da Zona de Cisalhamento de Além Paraíba, torna-se importante o esclarecer as relações estruturais entre granitos, metassedimentos e os gnaisses predominantes na região (Ebert et al. 1993).

Outro aspecto importante, neste tipo de estudo, é a definição da morfologia em profundidade dos corpos graníticos, onde a gravimetria tem se mostrado um dos métodos mais eficientes (Vigneresse 1995; Vigneresse \& Brun 1988). Nestes trabalhos, os autores analisam os leucogranitos do Maciço Armoricano, NW da França, com base na variação relativa de diferentes parâmetros: elipticidade, superfície, profundidade e distância.

Com os levantamentos gravimétricos realizados sobre o granito Mortagne (França), associado a Zona de Cisalhamento Armoricana, NW da França, foram obtidos também resultados significativos para definição da forma dos plutons (Vigneresse 1997b e 1983).

Os resultados demonstram a importância da deformação transcorrente regional no controle e posicionamento do magma granítico. Foram levantados e quantificados inúmeros plutons graníticos da região do Maciço Armoricano, incluindo parâmetros como forma do pluton, relação entre os eixos, maior e menor (elipticidade), os quais - ao contrário da geometria em gota vertical até então considerada na literatura para os plutons graníticos - mostram de forma inequívoca uma geometria em $3 D$ diferente para granitos associados à zonas de cisalhamento, onde o comprimento do pluton na 
horizontal (eixo maior) é cerca de 20 vezes maior do que a sua profundidade (Vigneresse op.cit.).

A densidade das estações gravimétricas nos granitos de Montargne, naqueles trabalhos, são relativamente numerosas (um registro gravimétrico por cada dois quilômetros), onde $95 \%$ dos maciços, mostraram-se alojados a menos de $5 \mathrm{Km}$ de profundidade, e em crosta continental superior.

Segundo (Vigneresse 1988), a precisão das medidas da profundidade e forma dependem da densidade e espaçamento entre as estações gravimétricas, bem como da altimetria, que não deve conter erros com valor superior a três metros.

A morfologia dos corpos graníticos em profundidade, bem como a posição e número de zonas enraizadas, varia de acordo com a natureza da deformação. A influência da deformação regional é decisiva no condicionamento da morfologia em $3 D$ resultante dos plutons graníticos. Outros parâmetros, como condições termais e nível crustal da deformação, são igualmente importantes no controle da morfologia dos mesmos.

A estrutura crustal e a composição petrológica são parâmetros que determinam a variação da disponibilidade de calor gerado e o controle das condições termais da crosta (Vigneresse 1995b).

As variações faciológicas podem também ser determinadas através de pequenas oscilações de anomalias gravimétricas (Hanmer \& Vigneresse 1980) sendo diretamente relacionadas a mudanças muito pequenas de densidades existentes no interior do corpo, lateral (variação faciológica) ou verticalmente (variação com a rocha encaixante).

No MGA foi possível determinar variações muito pequenas de contraste de densidade, que são da ordem de $0,01 \mathrm{~g} / \mathrm{cm}^{3}$, ou seja, de cerca de $1 \%$, nas suas diferentes faciologias.

Conforme referido por Hanmer \& Vigneresse (op.cit.) e Vigneresse 1990, as variações de densidades detectadas nas leituras gravimétricas permitem separar as mudanças de fácies. A precisão das medidas de profundidade e forma do plutons dependem do espaçamento das estações gravimétricas, bem como da precisão das medidas e acuidade das leituras efetuadas. A precisão considerada é inferior a 15\% para valores de densidades confiáveis em profundidade. O assoalho é modelado com maior precisão, abaixo de 5\%, desde que reflita a homogeneidade e a densidade das leituras.

O parâmetro crítico para cada tratamento é a constante de densidade $(\mathbb{A D}=0,08)$ entre o granito (que possui uma constante de densidade média de 2,62 ) e a rocha 
encaixante para uma densidade teórica de 2,70. A variação do cálculo de profundidade não é superior a $10 \%(d=0,008+-0,015)$, sendo sempre inferior a $20 \%$.

Para Karner \& Watts 1983, na definição das anomalias gravimétricas devem ser consideradas as feições topográficas relevantes, fazendo-se as devidas correções em sub superfície (compensação da profundidade de um determinado corpo rochoso), a exemplo do que tem sido feito nos trabalhos realizados nos Himalaias, Alpes e Apalaches, onde as fortes variações gravimétricas eram resultantes sobretudo das grandes diferenças fisiográficas.

Jardim de Sá et al. 1993, sintetizaram a aplicação do método gravimétrico do nordeste brasileiro e de outras regiões do Brasil - contribuições da Petrobrás, Observatório Nacional, CPRM, IBGE e universidades brasileiras - incluindo ilustrações na forma de cartogramas das anomalias Bouguer e Free-Air.

Em relação ao Estado Rio de Janeiro, tem-se o registro apenas de estudos gravimétricos realizados no município do Rio Janeiro, por Fernandes \& Rocha 1993, com o objetivo de delimitar o embasamento cristalino. Neste trabalho, os autores usaram os seguintes parâmetros para as reduções gravimétricas: correção Bouguer utilizando densidade de $1,75 \mathrm{~g} / \mathrm{cm}^{3}$, correção Free-Air com - 0,3086 mgal $/ \mathrm{m}$. e densidade de correção fisiográfica (terrain correction) de $2,65 \mathrm{~g} / \mathrm{cm}^{3}$.

Estes dados, mediante as grandes diferenças existentes principalmente no que se refere à fisiografia, não foram levados em conta para a região do Maciço Granítico Arrozal.

\subsubsection{Redução dos dados gravimétricos}

O método gravimétrico permite sugerir o tamanho e a forma de um determinado pluton, delineando a sua continuidade em profundidade. Variações especiais na densidade das anomalias do campo gravitacional podem, do mesmo modo, indicar zonamento geoquímico em profundidade, apófises encobertas, a existência de plutons não aflorantes, ou até mesmo zonamentos metamórficos (Vigneresse 1990).

Os dados obtidos, que irão constituir o mapa de anomalia residual, podem ser filtrados e analisados por computador através de vários programas de modelagem geofísicos, dentre eles: GraviPac, Surfer, Geosoft, Noddys, DataMine, Neural Network, etc. 
Além disso, o método gravimétrico, mede a variação do componente vertical da aceleração da gravidade a qual, após as devidas correções (Grant \& West 1965), carrega informação sobre a distribuição das massas em sub superfície.

A modelagem gravimétrica permite ainda, realizar o estudo tridimensional dos corpos graníticos, assim como discutir os aspectos genéticos envolvidos.

O problema crucial existente na análise e interpretação dos dados gravimétricos de magmas graníticos a nível regional brasileiro é, em última análise, o predomínio de alojamento granítico em crosta média, e a inexistência de uma malha gravimétrica mais fechada, para caracterizar anomalias existentes com contrastes de densidades até mesmo insignificantes. Neste item, deve-se ter como princípio básico, a formulação do modelamento com os dados verdadeiros, e somente filtrar os dados no final do processo.

Entende-se por anomalia gravimétrica, ou melhor residual, após a passagem dos dados pelos processos de filtragem, como o valor em sub superfície logo acima do lugar onde elas se localizam, gerado através da colocação lateral de rochas com diferentes densidades, que devido ao contraste, torna-se possível detectá-las, bem como estimar suas dimensões.

Para tanto, o valor residual obtido após a aplicação das correções do efeito da topografia, de latitude, Free-air e Bouguer, aos dados gravimétricos observados, denomina-se anomalia Bouguer.

$\mathrm{Na}$ anomalia Bouguer, o efeito da isostasia ainda não é corrigido, e o resultado é fornecido pela unidade de aceleração da gravidade, na prática em miligals $\left(1.10-3 \mathrm{~cm} / \mathrm{s}^{2}\right)$. Estas, variam de $200 \mathrm{mgal}$ à -40 ou - $240 \mathrm{mgal}$, através de batólitos graníticos, como é o caso do Batólito Granítico de Sierra Nevada (Oliver 1977), onde os maiores valores são causados primeiramente por elevações de zonas máficas enraizadas, em contraponto com aquelas zonas entre -5 à - 40 mgals associadas à plutons félsicos.

As variações químicas através do batólito com o incremento de $\mathrm{K}_{2} \mathrm{O}$, sugerem que a densidade pode variar sistemáticamente. A densidade decresce, porque a densidade do feldspato potássico é 2,54 a $2,57 \mathrm{~g} / \mathrm{cm}^{3}$, significantemente menor do que para o plagioclásio mais comum (An 25-35) que é 2,66 à 2,68g/ $\mathrm{cm}^{3}$ (Hurlbut 1971, p.464, 468).

Em Sierra Nevada, na borda leste ocorre um incremento na intensidade magnética total e decréscimo da gravimetria, onde a exposição de rochas graníticas apresentam elevados relações dos teores de $\mathrm{K}_{2} \mathrm{O} / \mathrm{Na}_{2} \mathrm{O}$ e $\mathrm{Fe}^{3} / \mathrm{Fe}^{2}$. Outra importante correlação geofísica e geoquímica, associam em mapa, isolinhas com iguais valores de $\mathrm{Sr}^{87} / \mathrm{Sr}^{86}$ (Batteman \& Dodge 1970). 
No Batólito Granítico de Maine, EUA, os plutons alojados a uma profundidade na ordem de $15 \mathrm{~km}$, em rochas de alto grau metamórfico, são espessos e aplainados e mostram pequenas anomalias Bouguer negativas, geralmente inferiores à $10 \mathrm{mgals}$. Os fatores importantes considerados naquele trabalho, que determinam a forma e o mecanismo de colocação dos plutons na costa de New England são: a profundidade de alojamento, a pressão interna do magma, largura do pluton, espessura da astenosfera $\mathrm{e}$ a presença de falhas pré-existentes.

A partir dos dados, abordaram o alojamento de corpos graníticos em crosta média a profundo, como formas laminadas, porque há uma grande dificuldade de ascensão destes materiais na interface crosta média - crosta superior.

\subsection{Gravimetria da regiäo de Arrozal}

O trabalho de gravimetria realizado na região de Arrozal e adjacências, teve como enfoque principal a coleta de dados do Maciço Granítico de Arrozal (MGA) e sua rochas encaixantes, bem como suas variações ao longo do corpo principal. Estes dados foram filtrados (GraviPac) e posteriormente plotados no mapa de anomalia Bouguer utilizando os programas SURFER (Fig.5.1) e DATA MINE (Fig.5.2).

Os traços principais dos alinhamentos de isovalores foram interpretados e sugerem a configuração de uma estrutura em flor (hemi-flor) em sub superfície associada diretamente a Zona de Cisalhamento de Além Paraiba, ao longo do Domínio Arrozal.

A partir dos valores determinados, pode-se sintetizar os seguintes dados:

1. Estimar provável área de abrangência da SIA, corroborando com os dados coletados no mapeamento geológico;

2. Salientar a influência da Zona de Cisalhamento Além-Paraíba na ascenção do MGA, bem como registrar as anomalias gravimétricas definindo traços lineares paralelos aos corredores de cisalhamento na região, em duas áreas principais: ao norte de menor intensidades e outra ao sul mais acentuada;

3. Caracterizar áreas de embasamento no entorno do SIA e confirmar a presença de corpos básicos em sub superfície (quase todos os corpos foram levantados gravimétricamente (com anomalias lineares paralelas aos corredores de cisalhamento).

O resultado final de extrema importância refere-se à profundidade de $7.500 \mathrm{~m}$. obtida para o MGA (final dos registros anômalos) que possibilitou construir o perfíl gravimétrico do MGA (Fig.5.3). 


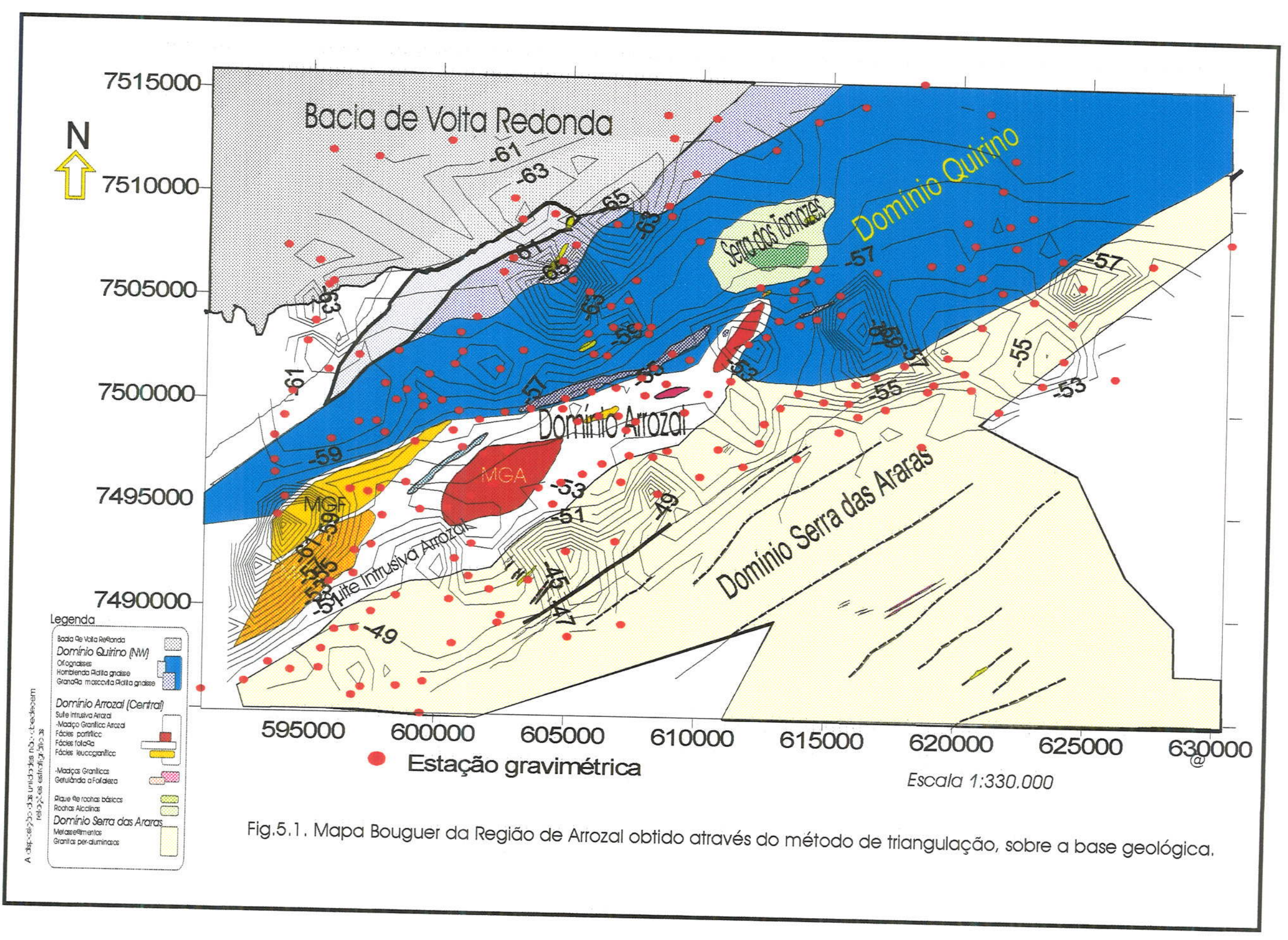



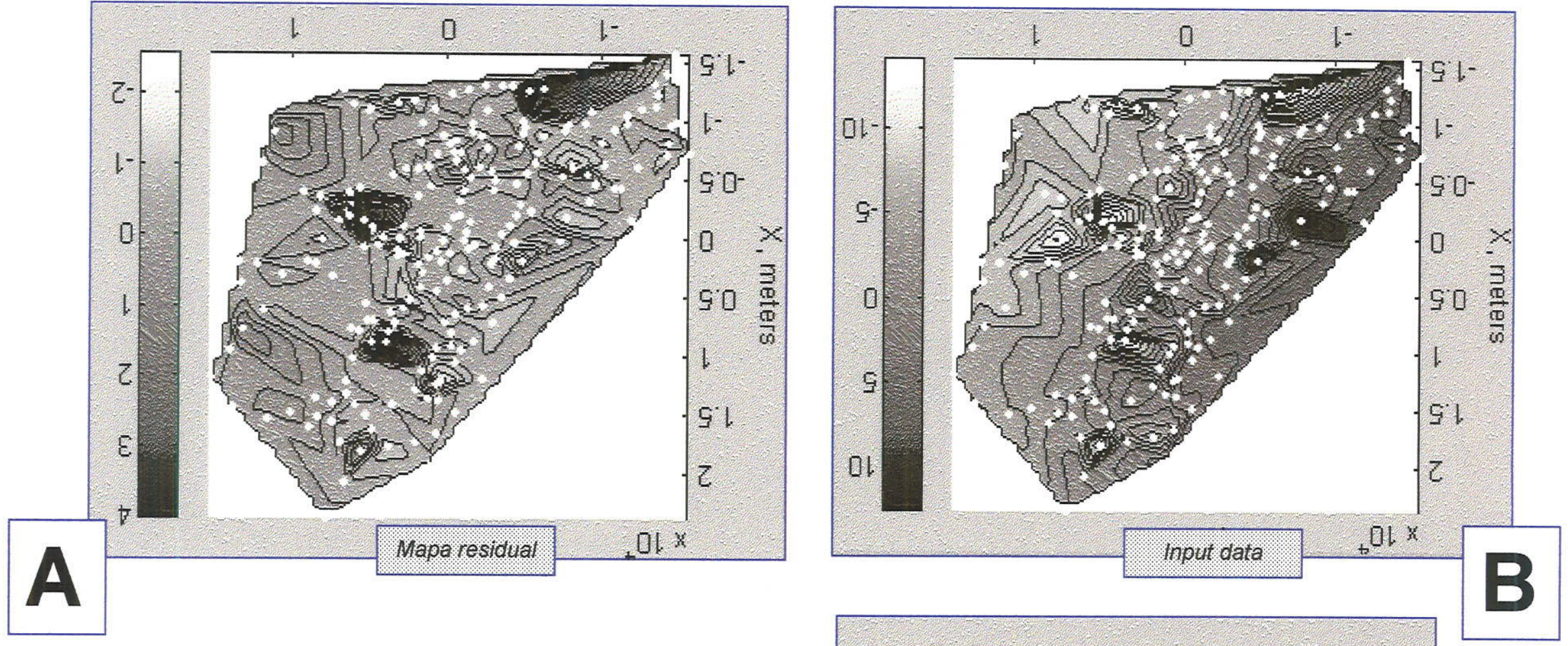

Figura 5.2 - Modelagem gravimétrica da SIA no programa Data Mine: (A) Mapa gravimétrico residual (próximo à superfície), (B) Mapa sem as correções gravimétricas (input data) e (C) Representação em $3 D$ do registro inferior das anomalias gravimétricas filtrados (nível de 7,500 m.).

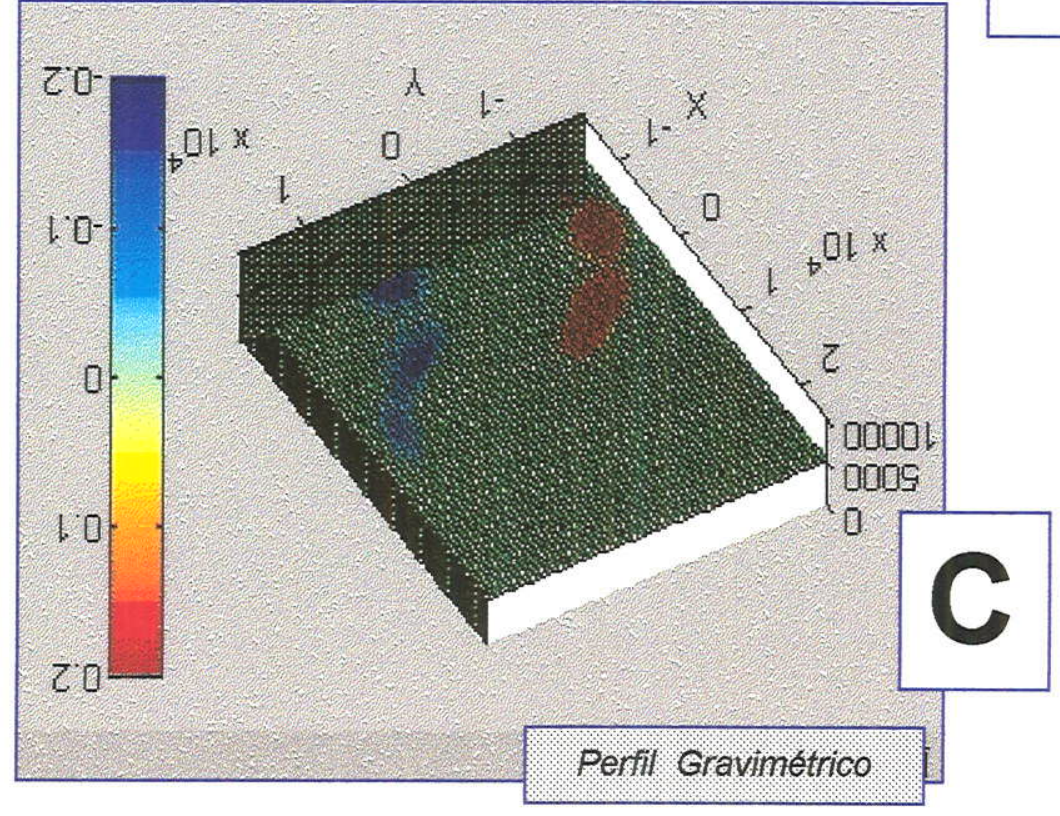




\subsection{Modelo de Alojamento da Suite Intrusiva Arrozal}

O modelo de alojamento para os granitos da Suíte Intrusiva Arrozal que melhor sintetiza a região estudada associa-se à fase final de uma colisão oblíqua entre os Crátons do Congo e São Francisco e a interação com a Cunha de Guaxupé.

Esta colisão continental pode ser dividida em dois estágios: primeiro uma colisão continente-arco de ilha com interação inicial obliqua, segundo, uma colisão continente. continente com margem não retilínea, representados pelos Crátons do Congo e São Francisco.

Um modelo tectônico regional em regime transpressivo tem sido proposto para explicar as zonas de cisalhamento dúcteis de alto ângulo do Cinturão Paraíba do Sul (Ebert et al 1991, Ebert et al. 1993, Machado \& Endo 1993, Silva 1996).

Neste contexto, instalou-se o Sistema de Cisalhamento Paraíba do Sul em regime tranpressivo (sensu Machado \& Endo 1993), com desenvolvimento de expressivas zonas de cisalhamento dúcteis de alto ângulo, onde a ZCAP é uma das mais importantes. A movimentação destral tardia desta zona em regime transpressivo propiciou o desenvolvimento de sítios extensionais nos segmentos de inflexão da mesma, favorecendo assim a ascensão e colocação de magmas graníticos. A contínua movimentação destral da ZCAP levou à deformação dos plutons graníticos então alojados, promovendo assim sua deformação no estado sólido, sobretudo junto às bordas dos maciços mais próximos das zonas de cisalhamento.

Em profundidade a ZCAP deve mudar seu mergulho de subvertical para inclinado, sendo isto compativel com as informações geológicas e geofísicas (gravimétricas) levantadas neste trabalho. Este aspecto pode estar vinculado à maior expressão do magmatismo granítico situado a leste desta zona (representado principalmente pelo Dominio Serra dos Órgãos).

O zonamento geoquímico descrito para os granitóides pré-colisionais brasilianos nesse segmento, com granitos mais cálcicos situados na porção interna do cinturão (SE) e mais postássicos na sua porção externa (NW), são elementos que favorecem a existência de uma zona subducção mergulinando para NW (Demange et al. 1991, Machado \& Demange 1996 e 1998, Machado 1997, Machado et al. 2000). Contudo, modelos com sentido diferente da subdução para SE têm sido propostos por outros autores (Tupinambá 1999). 
A Figura 5.4 ilustra os diferentes estágios do modelo tectônico proposto para o alojamento do granito Arrozal. A configuração geométrica da Zona de Cisalhamento de alto ângulo de Além-Paraíba, no estado do Rio de Janeiro, mostra uma mudança significativa na tendência regional do segmento sul desta zona, passando de $\mathrm{N} 45^{\circ} \mathrm{E}$ para aproximadamente $\mathrm{N} 70^{\circ} \mathrm{E}$. A evolução do deslocamento desta zona de cisalhamento em cinemática destral é o contexto tectônico favorável para o desenvolvimento de sítios extensionais com abertura de espaços para o posicionamento dos magmas graníticos (Figs.5.4b e 5.4c).

Neste modelo, a Zona de Cisalhamento Arrozal (destral), observada na porção norte do Domínio de Arrozal, deve ter sido instalada concomitante com a mesma fase de colocação dos pulsos magmáticos iniciais. Esta situação é coerente com a presença nesta zona de lineações de estiramento mineral oblíquas caindo para noroeste.

A idade U/Pb em monazita em de $530 \mathrm{Ma}$ (Valladares 1996) é aqui considerada a provável idade para cristalização e alojamento da SIA, devendo também corresponder à idade de uma importante movimentação das zonas de cisalhamento transcorrentes da região.

O SIA apresenta em toda sua extensão estruturas magmáticas preservadas, que são afetadas por processos de deformação em estado sólido concomitantes e subseqüentes à sua colocação. Esta deformação concentra-se nas bordas dos maciços, levando muitas vezes à geração de rochas miloníticas ou com bandamento gnáissico fino. As características apresentadas pelos maciço granítico Arrozal sugerem uma idade alojamento concomitante ou muito próxima da idade de cristalização do mesmo.

O desenvolvimento de uma foliação milonítica nas bordas do pluton de Arrozal, juntamente com a mudança do trend estrutural da foliação magmática na porção ao norte do mesmo, é compatível a cinemática destral considerado para a ZCAP.

Adicionalmente, os granitos exibem um aumento progressivo da deformação para as zonas de cisalhamento, sugerindo uma relação temporal entre o magmatismo e deformação.

Os dados estruturais (análise geométrica e cinemática) discutidos neste trabalho reforçam o modelo de que os granitos associados à ZCAP foram controlados regionalmente por uma fase tectônica posterior à fase relacionada com o metamorfismo regional, referida na literatura como fase sin-F3 (ou sin-D3) (Machado \& Demange 1994, Heilbron 1996). 

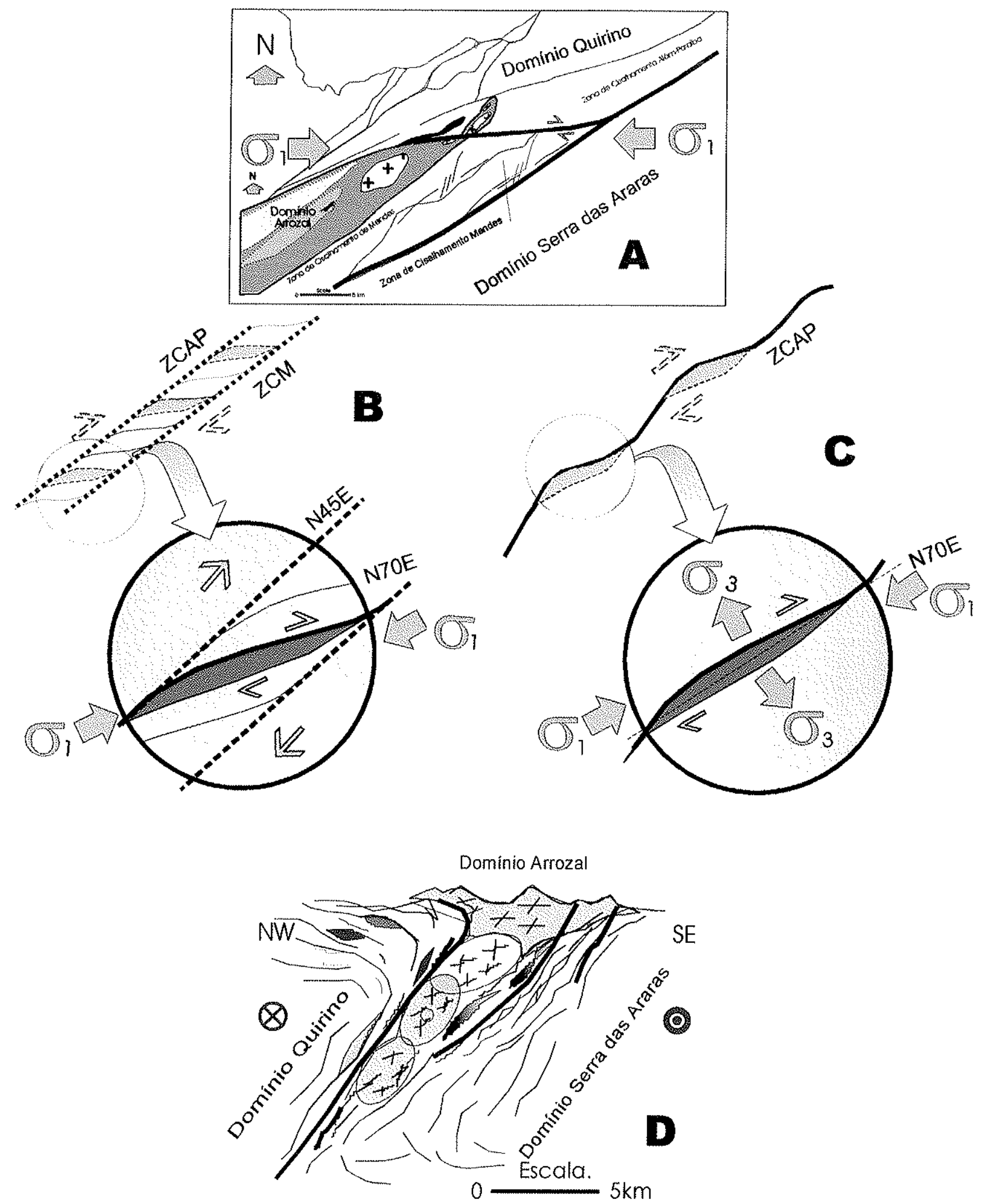

Fig.5.4. Modelo cinemático de alojamento da Suite Intrusiva Arrozal: A - Mapa geológico simplificado com a orientação do quadro de esforços regionais; $\mathbf{B}$ - Conexão entre duas zonas de cisalhamento ( Zona de Cisalhamento Além Paraiba - ZCAP e Zona de Cisalhamento Mendes - ZCM) e respectivo detalhe; $C$-Configuraçăo da ZCAP, mostrando os dominios extensionais "releasing bend" e o quadro cinemático local $\mathbf{F}$. Perfil geológico esquemático mostrando o posicionamento da Sulte Intrusiva Arrozal. 
Os dados geológicos-estruturais aqui apresentados são compativeis com o desenvolvimento de estruturas do tipo releasing bend associadas ao segmento sul da ZCAP, porção sudoeste do estado do Rio de Janeiro, sítios estes favoráveis para ascensão e colocação de magmas graníticos associados a SAl (Fig.5.4.c).

A permanente atuação de processos tectônicos regionais (representados pelos corredores de cisalhamento) nos granitos porfiróides da região de Arrozal favoreceram o processo de ascensão do material magmático, com desprendimento inicial de elementos voláteis (profusão em pegmatitos), produzindo assim o rebaixamento da temperatura e consequente aumento da viscosidade. Como resultado, ocorreu uma rápida cristalização de porções do magma granítico, resultando desse modo em graus variáveis de heterogeneidade no interior da câmara magmática (Fig.5.4d).

As estruturas de fluxo magmático estão bem preservadas nas bordas do Maciço Granítico de Arrozal, sendo aí evidenciadas pela orientação geral do fabric da rocha, incluindo presença de enclaves, diques ou bolsões aplíticos estirados e porções quartzo feldspáticas e/ou pegmatíticas.

A foliação deformacional é diferenciada da foliação de fluxo magmático por imprimir uma deformação no estado sólido dos minerais, inicialmente afetando o quartzo (em fitas contornando ou não os feldspatos), as micas e os feldspatos, com lenticularização e cominuição dos mesmos, com a rochas apresentando textura milonítica, ao lado de outras feições de deformação no estado sólido como: enclaves com forma de elipsóides oblatos ( $K<1$, campo do achatamento); presença de tectonitos SL; estruturas lineares subhorizontais (eixo $x$ da elipse de deformação), indicando encurtamento ortogonal ao plano foliação de alto ângulo, dentre outros.

Por outro lado, o Domínio Arrozal exibe uma tendência estrutural diferente, com a foliação magmática do granito Arrozal formando na parte norte um ângulo de cerca de $30^{\circ}$, enquanto na sua extensão sudoeste o trend estrutural das foliações torna-se sub paralelo ao trend estrutural dos domínios adjacentes (Fig. 3.1). 


\subsection{Consideraçōes finais}

O modelo em $3 D$ mais adequado para a colocação do magmatismo granítico da região de Arrozal é o de intrusões múltiplas, como proposto em Marsh (1982), associadas a diápiros em função dos seguintes elementos: padrões concêntricos da foliações, registro de fluxo magmático preservado na porção central do corpo, aumento do grau de deformação do núcleo para as margens da intrusão e concordância estrutural entre a intrusão e a foliação de borda (muitas vezes milonítica) com a estrutura dos gnaisses encaixantes.

O modelo proposto para a cinemática de alojamento do MGA é do tipo Releasing bend, termo este que tem sido utilizado para definir alojamento de granitos em sítios extensionais associados às inflexões de zonas de cisalhamento dúcteis de alto relacionadas geralmente com regimes transpressionais.

Estudos estruturais realizados no MGA, na Zona de Cisalhamento de AlémParaíba, sudoeste do Estado do Rio de Janeiro, sugerem um posicionamento em regime tectônico transpressivo destral. O MGA inclui granitos e granodioritos com estruturas magmáticas bem marcadas na sua parte central, que apresentam-se progressivamente deformadas no estado sólido em direção às suas bordas, apresentando-se muitas vezes como uma foliação milonítica. Os indicadores cinemáticos destes milonitos são compatíveis com a cinemática regional destral descrita para a ZCAP. 


\section{CAPITULO 6}

\section{Conclusőes}

O Maciço Granítico Arrozal (MGA) faz parte do magmatismo granítico Neoproterozóico da parte central do cinturão do Paraíba do Sul, com idades no intervalo de 600 a $490 \mathrm{Ma}$, que tem sido dividido em quatro grupos principais de granitos: (i) précolisionais; (ii) sin-colisionais; (iii) tardi-colisionais e, (iv) pós-colisionais. O MGA corresponde aos granitos classificados como tardi-colisionais (sin- a tardi-F3 das classificações tectônicas disponiveis nos trabalhos regionais).

Os trabalhos aqui realizados permitiram caracterizar este maciço, juntamente com outros maciços de mesma identidade estrutural e composicional (Getulândia e Fortaleza), como integrantes da Suite Intrusiva Arrozal.

O MGA, com expressão areal ao redor de $101,3 \mathrm{Km}^{2}$ (36 Km de extensão por $8 \mathrm{Km}$ de largura média), possui eixo maior orientado na direção $N 70^{\circ} E$, e encontra-se alojado entre as zonas de cisalhamento dúcteis de alto ângulo de Além-Paraíba (a noroeste) e Mendes (a sudeste), sendo seccionado a norte pela zona de cisalhamento de alto ângulo de Arrozal.

A cartografia geológica deste maciço permitiu individualizar, com base composicionais e deformacionais, três faciologias principais: porfiritica, situada na parte central do maciço, foliada, disposta marginalmente ao corpo, e leucogranítica, na sua extremidade nordeste. As duas primeiras faciologias possuem composição monzogranítica dominante, com granodiorítica subordinada, enquanto a última possui composiçăo quartzo monzonítica.

A área estudada foi dividida em três domínios estruturais: Domínio Quirino (domínio NW), Domínio Arrozal (domínio Central) e Domínio Serra das Araras (domínio SE). O primeiro domínio possui orientação geral $\mathrm{N} 75^{\circ} \mathrm{E}$, com mergulhos variáveis para NW e SE; - segundo, com orientação dominante na direção $\mathrm{N} 45^{\circ} \mathrm{E}$, apresenta mergulhos mais suaves para a foliação magmática e mais acentuados para a foliação tectônica; o terceiro, 
com orientação estrutural semelhante ao primeiro $\left(\mathrm{N} 69^{\circ} \mathrm{E}\right)$, mostra mergulhos mais elevados para NW.

Os dados geoquímicos possibilitaram caracterizar o MGA como magmatismo cálcicoalcalino alto $\mathrm{K}$ a shoshonítico, meta-aluminoso (A/CNK, 0,9, fácies leucogranítica) a marginalmente peraluminoso ( $\mathrm{A} / \mathrm{CNK}$, entre 1,1 a 1,2 , nas fácies porfirítica e foliada), apresentando durante a diferenciação empobrecimento em $\mathrm{Ca}, \mathrm{Sr}, \mathrm{Ba}, \mathrm{Zr}$ e na soma de FMMT $\left(\mathrm{Fe}_{2} \mathrm{O}_{3}+\mathrm{MgO}+\mathrm{MnO}+\mathrm{TiO}_{2}\right)$, e enriquecimento $\mathrm{K}_{2} \mathrm{O}, \mathrm{Rb}$, refletindo no primeiro caso a cristalização de feldspatos, zircão, apatita, biotita, ilmenita e magnetita, e, no segundo, principalmente de feldspato potássico.

$\mathrm{O}$ comportamento dos elementos maiores $\left(\mathrm{Ca}, \mathrm{K}_{2} \mathrm{O}, \mathrm{K}_{2} \mathrm{O} / \mathrm{Na}_{2} \mathrm{O}\right.$ e a soma dos FMMT) e traços ( $\mathrm{Sr}, \mathrm{Ba}, \mathrm{Zr}$ e $\mathrm{Rb}$ ) é muito semelhante durante a diferenciação entre as fácies porfirítica e foliada do MGA, mostrando que o processo deformacional (no estado sub sólido) não foi suficientemente intenso para promover alterações significativas no comportamento químico desses elementos. A comparação com as amostras do MGG evidencia o caráter mais evoluido deste último, com os teores mais elevados em $\mathrm{SiO}_{2}$ $(70,8$ a $75,3 \%$, contra 63,2 a $69,3 \%), \mathrm{K}_{2} \mathrm{O}(4,2$ a $4,6 \%$, contra 3,1 a $4,6 \%),\left(\mathrm{Na}_{2} \mathrm{O} / \mathrm{K}_{2} \mathrm{O}>\right.$ $1,8 \%$, contra 0,9 e $1,7 \%$ ) e Rb (252 e 327 ppm, contra 136 a 220 ppm).

A química mineral permitiu caracterizar nesses maciços a existência de dois grupos principais de plagioclásio: um de composição albita e oligoclásio no MGG, fácies leucogranítica, MGA e Domínio Quirino, e outro de composição andesina na fácies porfiritica e foliada do MGA, enclave quartzo diorítico do MGA e dique diorítico que corta o MGA. O feldspato alcalino dos maciços é essencialmente ortoclásio, com valores de An sempre inferiores a $20 \%$. Foram distinguidos dois grupos de biotitas: um grupo encontrado nos MGA e MGG, caracterizado por uma biotita muito férrica (annita), e outro grupo da fácies foliada do MGA, classificado como biotita magnesiana (siderofilita).

A modelagem gravimétrica apresenta uma boa correlação com dados estruturais obtidos e permitiu deduzir a geometria em 3D do corpo, indicando uma anomalia gravimétrica negativa com disposição coincidente com a Zona de Cisalhamento de Além Paraíba (ZCAP). O perfil gravimétrico obtido sugere o limite inferior do corpo a uma profundidade ao redor de 7,5 $\mathrm{km}$. Estes dados, em conjunto com os dados estruturais, permitem inferir uma geometria em perfil de uma estrutura-em-flor (hemi-flor) positiva 
associada às zonas de cisalhamento de Além-Paraíba e Mendes, que deve coalescer em profundidade.

O alojamento do MGA é compatível com zonas de cisalhamento dúcteis direcionais desenvolvidas em regime transpressivo, ao longo de um sítio extensional num modelo tectônico do tipo releasing bend. Esta estrutura associa-se regionalmente à inflexão da Zona de Cisalhamento de Além-Paraíba, que muda de direção geral N45E para direção N70 $\mathrm{E}$.

O modelo de alojamento de granitos aqui proposto pode ser aplicado para outros segmentos da Zona de Cisalhamento Além-Paraiba com situações tectônicas e magmáticas similares, a exemplo dos maciços Vassouras, Anta, Varre-Sai, dentre outros. Além disso, este modelo pode ser aplicado para outras regiões em contexto tectônico semelhante. 


\section{Referências bibliográficas}

ARZI, A.A. - 1978 - Critical phenomena in the rheology of partially melted rocks. Tectonophysics 44, 173-184.

ABALOS, B.; IBARGUCHI, J.I.G.; EGUILUZ, L. - 1991 - Cadomian subduction / collision and Variscan transpression in the Badajós Córdoba shear belt, soutwest Spain. Tectonophysics 199, 51-72.

ABDEL-FATTAH;-RAHMAN, A.M. - 1994 - Nature of biotites from alkaline, calc-alkaline and peraluminous magmas. J. of Petrol. 35(2): 525-541.

ALMEIDA, F.F.M.; BRITO NEVES, B.B.; CARNEIRO, C.D.R. - 2000 - The origin and evolution of the South American Platform. Earth Science Reviews 50 (2000): 77-111. ALMEIDA, F.F.M. - 1967 - Origem e evolução da Plataforma Brasileira. Bol. DGM/DNPM, Rio de Janeiro, 241:1-36.

ALMEIDA, F.F.M.; HASUI, Y.; BRITO NEVES, B.B. - 1976 - The Upper Precambrian of South America. Bol. Inst. Geoc., USP, São Paulo, 7: 45-80.

ALMEIDA, F.F.M.; HASUI, Y.; CARNEIRO, C.D.R. - 1975 - O lineamento de Além Paraíba. Anais Acad. Bras. Ciênc. Res. das Comum. 47(3/4): 575, RJ.

ALMEIDA, F.F.M; AMARAL, G.; CORDANI, U.G.; KAWASHITA, K. -1973 - The Precambrian evolution of the South American cratonic margin south of the Amazon River. in (A.E.M. Nairm; F.G. Stehli ed.). The Ocean Basin and Margins.

ALMEIDA, F.F.M.; HASUI,Y.; BRITO NEVES, B.B. - 1975 - The upper Precambrian of South America. Boletim IG-USP 7: 45-80.

ALMEIDA, J.C.H.; ALVES, M.J.S. - 1989 - Dados preliminares sobre o mapeamento litoestrutural em escala 1:10.000, no centro de niterói, RJ. In / Simp. Reg. Geol. SBG, RJ/SP, Bol.Res. Rio de Janeiro: 128-129.

ALMEIDA, J.C.H.; SILVA, L.G.E.; AVELAR, A.S. - 1991 - Coluna tectonoestratigráfica de parte do Complexo Paraíba do Sul na região de Bananal-SP. In Simpósio de Geologia do Sudeste, 2, São Paulo, Atas..., SP, SBG, 509-517.

ALMEIDA, J.C.H.; SILVA, L.G.E.; VALLADARES, C.S. - 1993 - O Grupo Paraíba do Sul e rochas granitóides na região de Bananal-SP e Rio Claro - RJ: uma proposta de formalização litoestratigráfica. In: Simpósio de Geologia do Sudeste, 3, São Paulo, 1993. Atas..., São Paulo, 155-160.

ALMEIDA, J.C.H.; TUPINAMBÁ, M.; HEILBRON, M.L.; TROUW, R.A.J. - 1998 Geometric and kinematic analysis of the central tectonic boundary of the Ribeira Belt, Southeast Brazil. In: Congresso Brasileiro de Geologia , 40, Belo Horizonte, Núcleo SBGMG, 1998. Anais..., Belo Horizonte, p. 32.

ALMEIDA, S.H.S. - 1996 - Estruturação tectônica da margem norte da Cunha de Guaxupé e suas relações com o Cinturão Transcorrente Campo do Meio. Seminário da Pós-Graduação IGCE/UNESP. Rio Claro: 181-184.

ALMEIDA, S.H.S. - 1997 - Compartimentação estrutural e evolução tectônica da borda norte da Sintaxe de Guaxupé na região de Alfenas (MG). In VI Simpósio Nacional de Estudos Tectônicos, Itatiaia, RJ. Atas... Rio de Janeiro: 72-74.

ANDERSON, E.M. - 1951 - The dynamic of faulting. Edinburgh. Oliver \& Boyd. 227p. ANDRE, F; BÉBIEN, J. - 1983 - Déchirures continentales et plutonisme: étude pétrologique et structurale comparée de l'association ignée de Guévguéli (Macédoine grecque) et des formations plutoniques basiques situées en bordure nord du Massif des Ballons (Vosges, France). Bull. So.géol.France (7), t.XXV, 3: 291-299. 
ARCHANJO, C.J.; OLIVIER, P; BOUCHEZ, J.L. - 1992 - Plutons granitiques du Serido (Nordeste du Brésil): Ecoulement magmatique parallèle à la chaîne relevé par leur anisotropie magnétique. Bull. Soc.geól. France, 163: 509-520.

ARTUR, AC.; WERNICK, E. - 1984 - Terrenos policíclicos e estágios de evolução crustal XXXIII Congr. Bras. Geol., Rio de Janeiro, Anais.. Rio de Janeiro, $3081-3090$.

ARTUR, A.C.; WERNICK, E, - 1986 - Interpretação geotectônica de alguns aspectos do embasamento cristalino do Estado de São Paulo e áreas adjacentes do Estado de Minas Gerais. In: Congresso Brasileiro de Geologia, 34, Goiânia, SBG, 3, 1285-1295.

ATHERTON, M.P.; SANDERSON, L.M. - 1987 - The Cordillera Blanca Batholith: a study of granite intrusion and the relation of crustal thickening to peraluminosity. Geol. Rundschau, 76/1, 213-232.

AUDRAIN, J.; AMICE, M.; VIGNERESSE, J.L.; BOUCHEZ, J.L. - 1989a - Gravimétrie et géométrie tri-dimensionnelle du pluton granitique de Cabeza de Araya (Extrémadure, Espagne). C.R.Acad. Sci.Paris, Ser. 2309: 1757-1764.

BABIN, R; BREGAMÍN, J; FERNÁNDEZ-RODRIGUEZ, C.; GONZALEZ-CASADO J.; HERNANDEZ ENRILE, J.; RIVAS, A.; TEJERO, R.; VICENT, G. - 1993 - Modélisation gravimétrique de la structure alpine du système central espagnol (secteur NE). Bull. Soc. géol. France, t.164, 3: 385-393

BABINSKI, M.; CHEMALE, F.; HARTMANN, L.A; VAN SCHMUS, W.R.; SILVA, L.C.1996 - Juvenile accretion at 750-700 Ma in Southern Brazil. Geology 24 (5): 439-442.

BARBARIN, B. - 1990 - Granitoids: main petrogenetic classifications in the relation to origin and tectonic setting. Geot. Journ. 25, 227-238.

.BARBOSA A.L.M.; GROSSI SAD, J.H. - 1983a - Reinterpretação das "séries" Juiz de Fora e Paraíba do Sul em Minas Gerais e no Rio de Janeiro. Relatório do Arquivo Técnico
da D.G.M, n²595. BARBOSA, A.L.M.; GROSSI SAD, J.H. - 1983a - Reinterpretação das "Séries" Juiz de Fora e Paraiba, em Minas Gerais e Rio de Janeiro. In Simpósio de Geologia de Minas Gerais, 3, Belo Horizonte, 1983. Anais... Belo Horizonte, 3, 1-10.

.BARBOSA, A.L.M.; GROSSI SAD, J.H. - 1983b - Petrologia dos charnockitos e rochas afins ao longo da divisa de Minas Gerais - Rio de Janeiro. In Simpósio de Geologia de Minas Gerais, 3, Belo Horizonte, 1983. Anais... Belo Horizonte, 3, 63-74.

.BARBOSA, A.L.M.; GROSSI SAD, J.H. - 1983c - Geoquímica e Petrologia dos charnockitos e rochas afins do Complexo Juiz de Fora, MG/RJ. In Simpósio de Geologia de Minas Gerais, 3, Belo Horizonte, 1983. Anais... Belo Horizonte, 3, 75-83.

BARBOSA, A.L.M.; GROSSI SAD, J.H. - 1985 - Batólito Granítico da Serra dos Orgãos, Estado do Rio de Janeiro, Brasil: Contribuição a Geologia e Petrologia. Boletim Especial do Núcleo de Minas Gerais, SBG, Belo Horizonte, 49-61.

BARROS CORREIA, P. - 1994 - Paleomagnetismo e Anisotropia da Suscetibilidade Magnética do Complexo Intrusivo de Itaqui, Estado de São Paulo. Tese de Doutorado.
IAG/ USP - São Paulo, $115 \mathrm{p}$.

BATCHELOR, G.K. - 1983 - Brownian diffusion of particucles with hydrodynamics interaction. Journal of Fluid Mechanics 75: 1-25.

BATCHELOR, R.A.; BOWDEN, P. - 1985 - Petrogenetic interpretation of granitoid rock series using multication parameters. Chem. Geol. 48, 43-55.

BATEMAN, P.C. - 1984 - On role of diapirism in the segregation, ascent and final emplacement of granitoid magmas. Tectonophysics 110, 211-231.

BATEMAN, P.C. - 1985 - Aureole deformation by flattening around a diapir during in situ balloning: the Cannibal Creek granite. J. Geol. 93, 293-310. 
BATEMAN, P.C. - 1988 - Constitution and genesis of the central part of the Sierra Nevada batholith. U. S. Geol. Surv. Open File Report 88-382, $188 p$.

BATEMAN, P.C. ; DODGE, F.C.W. - 1970 - Variations of major chemical constituents across the Central Sierra Nevada Batholith. Bull. Geol. Soc. Am. 81, 409-420.

BATEMAN, P.C.; CLARK, L.D.; HUBER, N.K.; MOORE, J.G.; RINEHART, C.D. - $1963-$ The Sierra Nevada batholith - a synthesis of recent work across the central part. Prof. Pap. U. S. Geol. Survey 414D, 46p.

BATISTA, J.J. - 1984 - Caracterização dos processos geológicos evolutivos pre cambrianos na região de São Fidélis, norte do Estado do Rio de Janeiro, (Tese de Doutorado - Instituto de Geociências/USP) $123 p$.

BATISTA, J.J. - 1986 - Processos geológico-evolutivos da porção setentrional do Cinturão Ribeira e na área estável adjacente. $X X X I V$ Congres. Bras. Geol., Goiânia, Anais, 2, $722-729$.

BATISTA, J.J.; KAWASHITA, K. - 1985 - Contribuição ao acervo geocronológico da porção setentrional do cinturão Ribeira .In Simpósio Regional de Geologia do Sudeste, 5. São Paulo, 1985. Atas...São Paulo, 1, 187-200.

BAYER, P.; HORN, H.; LAMMERER, B.; SCHMIDT-THOME, R.; WEBER-DIEFENBACH, K; WIEDEMANN, C.M. - 1986- The Brasiliano Mobile Belt in Southern Espirito Santo (Brazil) and its igneous intrusions. Zbl. Geol. Palaont. Teil. I, 9/10: 1429-1439.

BECKINSALE, R.D.; SANCHEZ-FERNANDEZ, A.W; BROOK, M; COBBING, E.J.; TAYLOR, W.P.; MOORE, N.D. - 1985 - Rb-Sr whole rock isochron and K-Ar age determinations for the Coastal Batholith of Peru. In (Pitcher, W.; Atherton, M.P.; Cobbing, E.J.; Beckinsale, R.D. eds.) Magmatism at a Plate Edge: the Peruvian Andes. John Wiley
\& Sons, 177-207.

BERGER, A.R.; PITCHER, W.S. - 1970 - Structures in granite rocks: a commentary and critique on granite tectonics. Proc. Geol. Ass. 81, 441-461.

BERTHE, D.P.; CHOUKROUNE, P.; JEGOUZO, P. - 1979 - Orthogneiss, mylonites and non-coaxial deformation of granites: the example of the South Armorican Shear Zone. $J$. Struct. Geol. 1, 31-43.

BETTENCOURT, J.S. - 1997 - Tin-Bearing granites of Brazil: a review. Extended Abstracts of Seccond International Symposium on Granites and Associated Mineralizations, Salvador, Bahia, 34-35.

BIGAZZI, G.; CORDANI, U.G.; KAWASHITA, K. - 1971 - Comparision between radiometric and fission trace ages of micas. An. Aca. Bras. de Ciênc., 43, 663-668.

BILAL, E.; HORN, A.H.; NALINI Jr,H.A.; MELLO, F.M.; CORREIA-NEVES, J.M.GIRET, A.R.; MOUTTE, J.FUZIKAWA, K.; FERNANDES, M.L.S. - 2000 - Neoproterozoic granitoid suites in southeastern Brazil. Revista Brasileira de Geociências volume $30(1,2 \mathrm{e}$
3) 70-73.

BITENCOURT, M.F; HACKSPACHER, P.C.; NARDI, L.V.S. - 1989 - In Simpósio Nacional de Estudos Tectônicos, 2., Fortaleza-CE, 1989. Boletim de Resumos Expandidos...Fortaleza, SBG, 214-216.

BITENCOURT, M.F; NARDI, L.V.S. - 1993 - Late to post-collisional Brasiliano magmatism in Southernmost Brazil. In Workshop Magma, magmatismo granítico e mineralizações associadas, Recife, PE. Resumos expandidos...SBG. Recife, Depto
Geologia da UFP, 116p.: 3-4.

BITENCOURT, M.F.; NARDI, L.V.S. - 2000 - Tectonic setting and sources of magmatism related to the southern Brazilian shear belt. Revista Brasileira de Geociências, SBG volume 30 (1,2 e 3): 184-187 
BITENCOURT, M.F.; NARDI, L.V.S.; HACKSPACHER, P.C. - 1989b Diques compostos da Enseada dos Zimbros, região de Porto Belo, SC. In Cong.Bras.Geoq. II, Rio de Janeiro. Anais... Rio de Janeiro, S. B. Geoq., 177-181.

.BITENCOURT, M.F.; HACKSPACHER, P.C.; NARDI, L.V.S. - 1989a- A zona de cisalhamento Major Gercino - Santa Catarina. In Simpósio Nacional de Estudos Tectônicos, /I, Fortaleza. Atas... Fortaleza, SBG: 214-216.

.BLANCHARD, J.P.; BOYER, P.; GAGNY, C. - 1979 - Un noveau critère de sens de mise en place dans une caisse filonienne: le "pincement" des mineraux aux Epontes. Tectonophysics 53, 1-25.

.BLUMENFELD, P. - 1983 - Le "tuilage des megacristaux", un critère d'écoulement rotationnel pour les fluidalités des roches magmatiques. Application au granite de BarbeySéroux (Vosges, France). Bull. Soc. Geol. Fr. 25, 309-318.

BLUMENFELD, P.; BOUCHEZ, J.L. - 1988 - Shear criteria in granite and migmatite deformed in the magmatic and solid states. J. Struct. Geol. 10, 361-372.

.BLUMENFELD, P.; MAINPRICE, D.; BOUCHEZ, J.L. - 1986 - C-slip in quartz from subsolidus deformed granite. Tectonophysics 127, 97-115.

.BORGES, S.V.F.; JARDIM DE SÁ, E.F.; LINS, F.A.P.L.; MEDEIROS, W.E.; BRITO NEVES, B.B. - 1995 - Alojamento do Granito Dona Ines, NE da Paraíba. In V Simpósio Nacional de Estudos Tectônicos - SNET, Gramado SBG -). Atas ... Gramado, 182-183.

BOWEN, N.L. - 1928 - The evolution of igneous rocks. Princeton. University Press, 322p. BRANDALISE, L.A. - 1976 - Projeto Vale do Paraiba do Sul; Relatório final. Belo Horizonte, DNPM / CPRM ; 411p.

BRAUN, O. - 1972 - Faixas rúpteis do Escudo Brasileiro. In: Congresso Brasileiro de Geologia, 27, Belém-PR, 1972. Manuscrito...Belém (inédito).

BRAUN, O. - 1975 - The coastal orogenic-belt structure of Southeastern Brazil. In: Simp. Continental Margins of Atlantic type. São Paulo, 31p. Manuscrito (inédito).

BRENNER, T.L.; FERRARI, A.; PENHA, H.M.- 1980 - Lineamentos estruturais no Norte do Estado do Rio de Janeiro. In: Congresso Brasileiro de Geologia, 31, Camboriú, 1980. Anais... Camboriú, 5: 2551-2564.

.BRENNER, T.L.; PENHA, H.M.; FERRARI, A.L.; JUNHO, M.C.B.; SOUZA, S.L.A.; PUGET, A.J.F. - 1982 - Geologia da Folha Itaipava. In Congresso Brasileiro de Geologia, 32, Salvador, 1984. Anais... Salvador, 1: 68-74.

.BRITO NEVES, B.B. - 1995 - Crátons e Faixas Móveis. Boletim IG/USP. Série Didátical Universidade de São Paulo, 7: 187p.

BRITO NEVES, B.B. - 1990 - Evolução monociclica vs. Policíclica em Faixas Brasilianas/Panafricanas. In XXXVI Congresso Brasileiro de Geologia, Natal, Anais... SBG. Núcleo Nordeste, Natal, RN, 6: 2497-2519.

.BRITO NEVES, B.B. - 1992 - Evolução monociclica vs. Policiclica em Faixas Brasilianas / Panafricanas. In XXXVI Congresso Brasileiro de Geologia, Natal, Anais... SBG. Núcleo Nordeste, Natal, RN, 6: 2497-2519.

BRITO NEVES, B.B. - 1992 - Faixas Móveis Proterozóicas: Problemas e Modelos. In: XXXVII Congresso Brasileiro de Geologia, São Paulo, Boletim de Resumos Expandidos... SBG. Núcleo Sudeste, São Paulo, SP, 1: 275-276.

.BROWN, G.C. - 1981 - Space and time in granite plutonism. Phil. Trans. R. Soc. Lond.,
301: $321-336$. BROWN, G.C.; THORPE, R.S.; WEBB, P.C.- 1984 - The geochemical characteristics of granitoids in contrasting arcs and comments on magma sources. J. Geol. Soc. Lond, 141: 413-426. 
BROWN, M. - 1993 - P-T-t evolution of orogenic belts and the causes of regional metamorphism. Journ. Geol. Soc. London 150: 227-241.

BROWN, M. - 1994 - The generation, segregation, ascent and emplacement of granite magma: the migmatite-to-crustally-derived granite connection in thickened orogens. EarthSci. Rev, 36: 83-130

BRUN, J.P. - 1977 - La zonation structurale des domes gneissiques. Un example: le massif de Saint-Malo, Massif Armoricain, France. In Canadian Journal of Earth Sciences 14(8): $1697-1707$.

.BRUN, J.P.; GAPAIS, D.; COGNE, J.P; LEDRU, P.; VIGNERESSE, J.L. - 1990 - The Flamaville Granite (Northwest France): an unequivocal example of a sintectonically expanding pluton. Geological Journal 25: 271-286.

.BRUN, J.P.; PONS, J. - 1981 - Strain patterns of pluton emplacement in a crust undergoing non-coaxial deformation. J. Struct.Geol. 3: 219-229.

BUDDINGTON, A.F. - 1959 - Granite emplacement with special reference to North America. Geol. Soc. Amer. Bull., 70: 219-229.

.BURG, J.P.; WILSON, C.J.L. - 1987 - Deformation of two phase systems with contrasting rheologies. Tectonophysics 135:199-205.

.BURG. J.P.; IGLESIAS, M.; LAURENT, P.H; RIBEIRO, A. - 1981 - Variscan intra continental deformation: the Coimbra-Córdobra shear zone (SW Iberian Peninsula). Tectonophysics, 78: 161-177.

BURG; J.P.; PONCE DE LEON, M.I. - 1985 - Pressure-solution structures in granites. J.Struct. Geol. 7: 431-436.

.CADDAH, L.F.G.; SANTOS, J.R.S.B.; VALENÇA, J.G.; PIRES, F.R.M. - 1987 Granitóides da Serra da Misericórdia (RJ): sucessão estratigráfia, posicionamento, forma e origem. In: Simpósio de Geologia RJ-ES, 1, Rio de Janeiro, 1987. Anais... Rio de Janeiro, 132-146.

CAMPANHA, G.A.C.; ENS, H.H. - 1993 - Lineamento de Além-Paraíba: um exemplo de zona de cisalhamento. In Simpósio de Geologia do Sudeste, 3, Rio de Janeiro, 1993. Boletim de Resumos e Breves Comunicações... Rio de Janeiro, 51-52.

CAMPANHA, G.A.C - 1980 - O Lineamento de Além-Paraiba na área de Três Rios, RJ. Dissertação de mestrado. IG/USP. São Paulo. 109 p.

.CAMPANHA. G.A.C. - 1991- O lineamento de Além-Paraíba na área de Três Rios-RJ. Rev. Bras. Geoc. 11 (3): 159-171.

.CAMPANHA, G.A.C.; FERRARI, A.L - 1984 - Lineamento Além Paraíba: um exemplo de zona de cisalhamento. In: XXXIII Congresso Brasileiro de Geologia, Rio de Janeiro, 1984, Anais... Rio de Janeiro, RJ, SBG, 12: 5425-5432.

CAMPANHA, G.A.C.; ESCUDERO, O. B.; SADOWISKI, G.R - 1993 - Análise da geometria e cinemática da zona de cisalhamento do Lineamento Ribeira, SP e PR. In VII Simpósio de Geologia de Minas Gerais, BH. Anais... Belo Horizonte, SBG.

CAMPANHA. G.A.C.; FERRARI, A. L. - 1984 - Lineamento de Além-Paraíba: um exemplo de zona de cisalhamento. In: Congresso Brasileiro de Geologia, 33., Rio de Janeiro, 1984. Boletim de excursões... Rio de Janeiro, 12: 5425-5432.

.CAMPOS NETO, M.C. -1991- A porção ocidental da Faixa Alto Rio Grande - ensaio de evolução tectônica. São Paulo. Universidade de São Paulo (Tese de Doutoramento Instituto de Geociências / USP) 210 p.

.CAMPOS NETO, M.C.; FIGUEIREDO, M.C.H. - 1990 - Evolução geológica dos terrenos costeiro, Paraiba do Sul e Juiz de Fora (Rio de Janeiro - Minas Gerais e Espirito Santo ) Anais do XXXVI Cong. Brasil. de Geol. - Natal, RN - 6: 2631-2648. 
CAMPOS NETO, M.C.; FIGUEIREDO, M.C.H. - 1992 - A Orogênese Rio Doce. In: Congres. Brasileiro de Geologia, 37, São Paulo, 1992. Boletim de Resumos Expandidos São Paulo, SBG, 1: 276-277.

CAMPOS NETO, M.C.; FIGUEIREDO, M.C.H. - 1995 - The Rio Doce Orogeny, Southeastern Brazil. J. South Amer. Earth Sci, 8 (2): 143-162.

CAN, J.R. - $1970-\mathrm{Rb}, \mathrm{Sr}, \mathrm{Y}, \mathrm{Zr}$ and $\mathrm{Nb}$ in some ocean floor basaltic rocks. Earth Planet. Sci. lett., 10: 7-11.

CAPDEVILA, P.; CORRETEGE, G.; FLOOR, P. - 1973 - Les granitoïdes varisques de la Méséta Ibérique. Bull. Soc. Géol. Fr. 80: 209-228.

CARLE, S.F. - 1988 - Three-dimensional gravity modeling of the geologic structure of Long Valley Caldera. Jour. Geophy. Res., 93, B11: 13.237-13.250.

CASTRO, A.; STEPHENS -1992 - Canadian Mineralogists 30: 1039-1112.

CASTRO, A. - 1985 - The central extremadura batholith: geotectonic implications (European Hercynian Belt) - an outline. Tectonophysics 120: 57-68.

CASTRO, A. - 1986 - Structural pattern and ascent model in the Central Extramadura Batholith, Hercynian belt, Spain. J. Struct. Geol. 8: 633-645.

CASTRO, A. - 1987 - On granitoid emplacement and relacted structures. A review. Geologische Rundschau 76/1: 101-124.

CASTRO, H.O.; QUEIROZ, M.A.; BARBOSA, A.L.M.; GROSSI SAD, J.H. - 1984a Geologia das folhas Rio Preto, Valença, Barra do Piraí e Vassouras. In Congresso Brasileiro de Geologia, 33, Rio de Janeiro, 1984. Anais...Rio de Janeiro, 5: 2346-2354.

CASTRO, H.O.; ROCHA, R.L.S.; SPERLING, E.V.; BALTAZAR, O.F. - 1984b - Geologia das folhas Mangaratiba, llha Grande, Cunhambebe, Angra dos Reis, Rio Mambucaba/Campos de Cunha, Picinguaba e Juatinga - RJ. In Congresso Brasileiro de Geologia, 33, Rio de Janeiro, 1984. Anais...Rio de Janeiro, 5: 2355-2367.

CHAPPELL, B.W. - 1984 - Source rocks of $I$ and $S$ type granites in the Lachlan Fold belt, southeastern Australia. Phil. Trans. R. Soc. Lond. A3 10: 693-707.

.CHAPPELL, B.W; STEPHENS, W.E. - 1988 - Origin of infracrustal (I-type) granite magmas. Trans. Royal Soc. Ed.: Earth Sci., 79: 71-86.

.CHAPPELL, B.W.; WHITE, J.R. - 1974 - Two contrasting granite types. Pacific. Geol., 8 : 173-174.

CHAPPELL, B.W.; WHITE, J.R. - 1984 - I- and S-type granites in the Lachlan Fold Belt, southeastern Australia. In: Xu Kepin and Tu Guangchi (eds.): Geology of granites and their metallogenic relations. Beijing: Science Press. 87-101 p.

CHAPPELL, B.W; WHITE, J.R. - 1992 - 1- and S-type granites in the Lachlan Fold Belt. Trans. R. Soc. Edinburg: Earth Sciences, 83: 1-26.

CHAPPELL, B.W.; WHITE, J.R.; HINE, R. - 1988 - Granites province and basement terranes in the Lachlan Fold Belt, southeastern Australia. Austr. J. Earth Sci., 35: 505-521.

CHAVES, M.L.S.C.; PIRES, F.R.M. - 1986 - Distribuição, gênese e significado econômico dos granitos do morros da Bica e Inácio Dias, Rio de Janeiro, RJ. In Congresso Brasileiro de Geologia, 34, Goiânia, 1986. Anais...Goiânia, SBG, 4: 2879-2889.

.CHEVREMONT, P.; CAGNY, C.; LA ROCHE, H.:PUPIN,J.P.; ROSSI, P. - 1988 Representation cartographique du plutonisme intermédiaire associé. Documents du $B R G M, 152,61 \mathrm{p}$.

CHOUKROUNE, P. - 1994 - Déformations et déplacements dans la croûte terrestre. 1ed.,

Paris, Masson, 226p.

CHOUKROUNE P.; GAPAIS, D. - 1983 - Strain pattern in the Aar granite (Central Alps): orthogneiss developed by bulk inhomogeneous flattening. J.Struct. Geol. 5: 411-418. 
CHRISPIM, S; TUPINAMBÁ, M.A. - 1989 - Observações sobre o caráter transpressivo da deformação entre as zonas de cisalhamento do Paraiba do Sul (RJ) e Guaçuí (ES). In Simpósio de Geologia do Sudeste, I, Anais..., Rio de Janeiro, SBG/RJ, 120-121.

CLEMENS, J.D. - 1998 - Observations on the origins and ascent mechanisms of granitic magmas, Journal of Geological Society, London, 155: 843-851.

CLEMENS, J.D.; MAWER, C.K. 1992. Granitic magma transport by frature propagation. Tectonophysics 204: 339-360.

CÓDIGO DE NOMENCLATURA ESTRATIGRÁFICO - Guia de Nomenclatura estratigráfica. Imprenta: Revista Brasileira de geociências, 16 (4): 370-415, dez.1986. Autor: Comissão Especial de Nomenclatura Estratigráfica da Soc. Brasileira de Geologia CENE ISBG.

.CORDANI, U.G.; DELHAL, J.; GOMES, C.B.; LEDENT, D. - 1968 - Nota preliminar sobre idades radiométricas em rochas da região da Serra do Orgãos e vizinhanças (Leste de Minas Gerais e Estado do Rio de Janeiro). Bol. Soc. Bras., São Paulo, 17 (1): 89-92.

.CORDANI, U.G.; DELHAL, J.; LEDENT, D.-1973 - Orogénèses superposées dans le PréCambrian du Brésil Sud-Oriental (États de Rio de Janeiro et de Minas Gerais). Rev. Bras. Geoc., $3(1): 1-22$.

.CORDANI, U.G.; MELCHER, G.C.; ALMEIDA, F.F.M. - 1968 - Outline of the precambrian geochronology of South America. Can. J. Earth Sci, 5: 629-632.

.CORDANI, U.G.; TEIXEIRA, W. - 1979 - Comentários sobre as determinações geocronológicas existentes para as regiões das folhas Rio de Janeiro, Vitória e Iguape. Texto Explicativo da Carta Geológica ao Milionésimo, folhas Rio de Janeiro (SF-23), Vitória (SF-24) e lguape (SG-23). Brasília, DNPM, 175-207.

.CORREA NETO, A. V. - 1995 - Geologia e análise estruturaldo Lineamento de Além Paraiba entre Três Rios (RJ) e Sapucaia (RJ). Dissertação de mestrado, Universidade Federal do Rio de Janeiro.

.CORREA NETO, A. V., DAYAN, H.- 1994 - Justaposição tectônica de rochas de nivel crustais distintos em faixas transpressivas: o caso da Zona de Cisalhamento do Rio Paraíba do Sul. In SXXXVIII Congresso Brasileiro de Geologia, SBG-SC. Balneário de Camboriú (SC). Anais...Camboriú, SBG, 249-250.

CORREA NETO, A. V., DAYAN, H.; VALENÇA, J.G.; CABRAL, R.A.- 1993 - Geologia e estrutura da zona de cisalhamento do Rio Paraíba do Sul e adjacências no trecho entre Tres Rios (RJ) e Sapucaia (RJ). In Simpósio de Geologia do Sudeste, 2, Rio de Janeiro. Atas... Rio de Janeiro, SBG, 239-245.

CORREA NETO, A.V.; DAYAN, H.; VALENÇA, J.G.; RAPHAEL CABRAL, A. -1993 Geologia e estrutura da Zona de Cisalhamento do Rio Paraiba do Sul e adjacências, no trecho entre Três Rios e Sapucaia (RJ). In Simp.Geol.Sudeste III, Rio de Janeiro, 1993, Atas..., Rio de Janeiro, SBG, 194-200.

.CORRIOUX, G. - 1983 - Example de mise en place d'un leucogranite pendant le fonctionnement d'une zone de cisaillement: le granite hercynien de Puentedeume (Galice, Espagne). Bull. Soc. Géol. France 7, t.XXV (3): 301-307.

CORRIOUX, G. - 1987 - Oblique diapirism: the Criffel granodiorite / granite zoned pluton (southwest Scotland). J. Struct.Geol. 9: 313-330.

COSTA, A.F.U. - 1997 - Teste e modelagem geofísica da estruturação das associações litotectônicas pré-Cambrianas no escudo Sul-RiomGrandense. Tese de Doutorado IGEOC-UFRGS, $180 \mathrm{p}$.

COSTA, L.A.M.; MARCHETTO, C.M.L.- 1978 - Evolução Textural dos Granulitos de São

Fidélis - RJ. III Congresso Brasileiro de Geologia 3: 1250-1264. 
COWARD, M.P - 1981 - Diapirism and gravity tectonics: report of a Tectonic Studies group. Journal Structural Geology 3: 89-95.

.CRAWFORD, M.D.; SEARLE, M.P. - 1992 - Field relanships and geochemistry of precollisional (India-Asia) granitoid magmatism in the central Karakoram, northern Pakistan. Tectonophysics 206: 171-192.

.CRESPO-BLANC, A. - 1992 - Structure and kinematics of a sinistral transpressive suture between the Ossa-Morena and the South Portuguese zones, south Iberian massif. Journ. Geol. Soc. London 149: 401-411.

CRUNDEN., A.R. - 1988 - Deformation around a rising diapir modeled by creeping flow past a sphere. Tectonics 5: 1091-1101

D'LEMOS, R.S.D.; BROWN, M; STRACHAN, R.A. - 1992 - Granite magma generation, ascent and emplacement within a transpressional orogen. Journ. Geol. Soc. London 149: 487-490.

D'LEMOS, R.S.D.; STRACHAN, R.A.; TOPLEY, C.G. - 1992 - The Cadomian orogenesis in the North Armorican Massif: a brief review. In (D'LEMOS, R.S.D.; STRACHAN, R.A.; TOPLEY, C.G. eds.) the Cadomian orogenesis: Geol. Soc. Spec. Publ. 51: 3-12.

DAYAN, H.; CORREA NETO, A.V.; J.G.- 1993 - A zona de cisthamento do Rio Paraíba do Sul: estudo de padrões preferenciais de eixos-C de quartzo. In IV Simpósio Nacional de Estudos Tectônicos. Atas...SBG - Núcleo MG, Bol.12: 339-342.

DAYAN, H.; CORREA NETO, A.V.- 1995 - Evolução de tramas de eixos-C de quartzo na Zona de Cisalhamento do Rio Paraiba do Sul. In V Simpósio Nacional de Estudos Tectônicos. Atas... Gramado, RGS (4): 118-120.

DAYAN, H.; CORREA NETO, A.V.- 1997 - Re-milotitização nas rochas da llha dos Pombos (RJ), Rio Paraíba do Sul. In VI Simpósio Nacional de Estudos Tectônicos. Atas... Itatiaia, RJ: 219-220.

DAYAN, H.; KELLER, J.V.A.- 1989 - A zona de cisalhamento do Rio Paraíba do Sul nas vizinhanças de Três Rios (RJ): uma análise da deformação dada por algumas feições estruturais. Rev. Bras. Geoc. 19 (4): 494-506.

.DE LA ROCHE, H.; LETERRIER, J.; CLAUDE, P.G.; MARCHAL. M. - 1980 - A classification of volcanic and plutonic rocks using R1-R2 diagrams and major element analyses - its relationships with current nomenclatures. Chem. Geol. 29: 183-210.

.DEBON, F.; LE FORT, P. - 1983 - A chemical-mineralogical classification of common plutonic rocks and associations. Trans. Royal Soc. Ed.: Earth Sci. 73: 135-149.

.DELHAL, J.; LEDENT, D.; CORDANI, U.G. - 1969 - Ages U/Pb, Rb/Sr et K/Ar de formations métamorphiques et granitiques du Sud-Est du Brésil (États de Rio de Janeiro et de Minas Gerais). Ann. Soc. Géol. Belg. 92: 271-283.

.DEMANGE, M., MACHADO, R.; MONTEIRO, R.L. - 1991 - Les granitöides brésiliens des ceintures Ribeira (état de Rio de Janeiro) et Dom Feliciano (état du Rio Grande do Sul) (Brésil). In: Colloque surles granites, Soc. Géol. Fr., Paris, 1991.

DEN TEX, E. - 1969 - Origin of ultramafic rocks, their tectonic setting and history: a contribuition to the discussion of the paper: The origin of ultramafic and ultrabasic rocks, (by P.J.Wyllie). Tectonophysics 7: 457-488.

DERBY, O.A. - 1880 - On The Age of The Brazilian Gneiss Series Discovery of Eozon. Am. J. Sc. 3, XIX: 324-326.

.DIAS NETO, C.M.; TASSINARI, C.C.G.; EGYDIO SILVA, M. - 1995 - Idades Rb-Sr das rochas da região de Bananal-SP. Boletim do IG-USP, Série Cient. 26: 59-68.

.DIDIER, J.; DUTHOU, J.L.; LAMEYRE, J. - 1982 - Mantle and crustal granites: genetic classification of orogenic granites and the natures of their enclaves. J. Volcanol. Geotherm. Res. 14: 125-132. 
.DIXON, J.M. - 1975 - Finite strain and progressive deformation in models of diapiric structures. Tectonophysics 28: 89-124

DRM- DEPARTAMENTO DE RECURSOS MINERAIS - 1978 - Projeto Carta Geológica do Estado do Rio de Janeiro. Folha Geológica Cambuci. Texto Explicativo e Mapa, Niterói, RJ.

DROOP, G.T.R. - 1987 - A general equation for estimating $\mathrm{Fe}^{+3}$ concentration in ferromagnesian silicates and oxides from microprobe analyses using stoichiometric criteria. Mineralogical Magazine 51: 431-435.

DUARTE, B.P.; HEILBRON, M.; CAMPOS NETO, M.C. - 2000 - Granulite/Charnockite from the Juiz de Fora Domain, central segment of the Brasiliano Ribeira Belt .In: Revista Brasileira de Geologia, SBG (30) 3: 358-362.

EBERT, H. - 1967 - A estrutura pré-Cambriana do Sudoeste de Minas Gerais e áreas adjacentes. Extraído do Bol. Paran. Geoci. 26: 42-45.

EBERT, H. - 1954 - Pesquisas na parte do Estado de Minas Gerais. Relatório Anual da Divisão de Geologia e Mineralogia, Rio de Janeiro: 79-89.

EBERT, H. - 1955 - Relatório dos trabalhos que realizou. Relatório Anual da Divisão de Geologia e Mineralogia, Rio de Janeiro: 97-107.

EBERT, H. - 1971 - Os Paraibides entre São João Del Rei, Minas Gerais, e Itapira, São Paulo, e a bifurcação entre Paraibides e Araxaides. In Congresso Brasileiro de Geologia, 37, São Paulo, 1971. Resumos das Comunicações, SP, SBG (Bol. Esp.) 1: 177-188.

EBERT, H. -1962 - Baustil und regionalmetamorphose in prakambrishen grundgebige brasiliens. Miner. Petrog. Mitt., Wien, 8, H.1: 49-81.

EBERT, H. -1968- Ocorrência da fácies granulítica no sul de Minas Gerais e em áreas adjacentes em dependência da estrutura orogênica: Hipóteses sobre a sua origem. Anais da Academia Brasileira de Ciências. Rio de Janeiro, 40: 215-30. Suplemento.

EBERT, H.D.; CHEMALE Jr, F.; BABINSKI, M.; ARTUR, A.C.; VAN SCHMUS, W.R. 1996- The tectonic setting and U/Pb zircon dating of the plutonic Socorro Complex in the Transpressive Rio Paraiba do Sul Shear Belt. Tectonics 15 (2): 688-699.

EBERT, H.D; HASUI, Y.- 1988 - Tectônica transpressiva no bloco Tunas, vale do RibeiraPR. In Simpósio de Geologia do Nordeste, 13, Fortaleza, 1989. Atas...Fortaleza, 11, 255257.

EBERT, H.D.; HASUI Y.; COSTA, J.B.S. - 1991 - O caráter transpressivo do Cinturão de Cisalhamento Rio Paraiba do Sul. In III Simp. Nacional de Estudos Tectônicos Rio Claro, SP. Boletim..., IGCE/UNESP-SBG/SP, Rio Claro-SP, 139-141.

EBERT, H.D.; HASUI, Y., SARTORO, G., ALMEIDA, S.H.; COSTA, J.B.S. - 1993 Arcabouço estrutural e tectônica transpressiva das faixas móveis da borda sul e sudeste do cráton do São Francisco e da síntaxe de Guaxupé. In Simpósio Nacional de Estudos Tectônicos, 4., Belo Horizonte, 1993. Atas... Belo Horizonte, SBG, 166m171.

EBERT, H.D; MALAGUTTTI FILHO, W.; HASUI, Y., HARALYI, N.; HACKSPACHER P.C.; MORALES, N. SOUZA, C.A. - 1997 - Compartimentação crustal do sul de Minas Gerais a partir de dados gravimétricos e lito-estruturais. In Simpósio Nacional de Estudos Tectônicos, 6., Itatiaia, RJ-1993. Atas... Itatiaia, RJ, SBG, 31-35.

EBERT, H.D.; NEVES, MA.; HASUI, Y.; SZATMARI, P.; AIRES, J.R. - 1993b - Evolução dos cinturões de cisalhamento entre os blocos São Paulo, Vitória e Brasília, através da tectônica colisional oblíqua: uma modelagem física. In Simpósio Nacional de Estudos Tectônicos 4, B. Horizonte. Anais... Belo Horizonte, SBG. Boletim do Núcleo SBG/MG, 12 : 254-258. 
EBERT, H.D.; NEVES, M.A.; HASUI, Y; LOPES, J.A.; GUERRA, M. - 1995 Compartimentação crustal e evolução cinemática da Província Mantiqueira através de modelagem física. In $V$ Simp. Est. Tect, Bol. Res. Expan... Gramado, UFRGS, 1995.445p., 26-28.

EBERT, H.D.; NEVES, M.A; HUTTON, D.H.M.; GUERRA, M. - 1995 - Alojamento de rochas plutônicas em regimes transpressivos: uma modelagem experimental. In $V$ Simp. Est. Tect., Bol. Res. Expan... Gramado, UFRGS, 1995.

EBERT, H.D.; NEVES, M.A.; HASUI, Y.; LOPES, J.A.; GUERRA, M. - 1995 Compartimentação crustal e evolução cinemática da Província Mantiqueira através de modelagem física. In $V$ Simp. Est. Tect., Bol. Res. Expan... Gramado, UFRGS, 1995.445p.: 26-28.

EBERT, H.D.; HASUI, Y.; SARTORATO, G.; ALMEIDA, S.H.S; COSTA, J.B. - $1993 a-$ Arcabouço estrutural e tectônica transpressiva das faixas móveis das bordas sul e sudeste do Craton do São Francisco e da Sintaxe de Guaxupé. In Simpósio Nacional de Estudos Tectônicos 4, Belo Horizonte. Anais... Belo Horizonte, SBG. Boletim do Núcleo SBG/MG, 12: 166-171.

EBERT H.D.; NEVES, M.A.; HASUI Y.; SZATIMARI, P.; RIBEIRO, A. - 1993 - Evolução dos Cinturões de cisalhamento entre os Blocos São Paulo, Vitória e Brasilia através da tectônica colisional oblíqua: uma modelagem física. In: IV Simp. Nacional de Estudos Tectônicos Rio Claro,SP. Boletim 12., IGCE/UNESP-SBG/SP, Rio Claro-SP: 254-258.

EGGLETON, R.A.; BUSECK, P.R. - 1980 - The orthoclase-microcline inversion: a highresolution transmission electron microscope study and strain analysis. Contr. Miner. Petrol. 74: 123-133.

EHLERS, C.; LINDROOS, A.; SELONEN, O. - 1993 - The late Svecofennian granitemigmatite zone of Southern Finland- a belt of transpressive deformation and granite emplacement. Prec. Res. 64: 295-309.

ENDO, I. - 1997 - Regimes tectônicos do Arqueano e Proterozóico no interior da Placa Sanfranciscana: Quadrilátero Ferrifero e áreas adjacentes, Minas Gerais. Tese de Doutoramento, IG - USP - São Paulo; 237p.

FASSBINDER, E. - 1996 - A formação Água Clara no contexto do Grupo Açungui: um modelo transpressivo de colisão obliqua no Neoproterozóico paranaense. São Paulo, Universidade de São Paulo (Tese de Doutorado - Instituto de Geociências/USP) 207 p.

FASSBINDER, E.- 1990 - Análise estrutural da falha da Lancinha no Estado do Paraná. Universidade de São Paulo (Dissertação de Mestrado - Instituto de Geociências/USP)
$165 \mathrm{p}$.

FASSBINDER, E.; MACHADO R. - 1996 - Aplicação do modelo transpressional no Grupo Açungui (Estado do Paraná): evidências e discussões. In Congresso Brasileiro de Geologia, 39, Salvador, 1996. Anais...Salvador, SBG, 1: 387-389.

FASSBINDER, E.; MACHADO R.- 1996 - Reavaliação dos modelos tectônicos existentes sobre o Grupo Açungui: uma proposta de modelo alternativo. In Congresso Brasileiro de Geologia, 39, Salvador, 1996. Anais...Salvador, SBG, 6: 54-57.

FASSBINDER, E.; SADOWSKI, G.R.; FIORI, A.P. - 1992 - Análise estrutural e cinemática da falha da Lancinha no Estado do Paraná. In Congresso Brasileiro de Geologia, 37, São Paulo, 1992. Boletim de Resumos Expandidos... São Paulo, SBG, 2, p. 362.

FASSBINDER, E.; SADOWSKI, G.R.; FIORI, A.P. - 1994 - O modelo de Riedel aplicado ao lineamento Lancinha no Estado do Paraná. Boletim Paranaense de Geociências 42: 173-184.

FAURE, G. - 1986 - Principles of isotope geology. 2 ed., New York, John Wiley, 589p. 
FERNANDES, L.A.D.; KOESTER, E. - 1997 - An overview of a Neoproterozoic intracontinental strike-slip shear zone and its role in the evolution of the continental crust in Southern Brazil. In VI Simpósio Nacional de Estudos Tectônicos, Itatiaia, RJ. Atas ... Itatiaia, RJ, 83-84.

.FERNANDES, L.A.D.; KOESTER, E.; SOLIANI, Jr., E. - 1995 - Evolução do sistema de zonas de cisalhamento transcorrentes Dorsal de Canguçu no Cinturão Dom Feliciano durante o Neoproterozóico: uma discussão. In $V$ Simp. Est. Tect., Bol. Res. Expan... Gramado, UFRGS. 445p., 26-28.

FERNANDES, L.A.D; TOMMASI, A.; PORCHER, C.C. - 1992 - Deformation patterns in the Southern Brazilian branch of the Dom Feliciano belt: a reappraisal. J. South Am. Earth Sc., 5: 76-84.

PORCHER, C.C. FERNANDES, L.A.D. - 1999 - Metamorphic conditions in a deep seated transcurrent shear zone of southern Brazil. In Anais da Academia Brasileira de Ciências,
71 , pt.1): p. 823 .

FERNANDEZ, A.N.; TEMPIER 1977 FERNANDEZ, A.N.; GASQUET, D.R. - 1994 Relative rheological evolution of chemically contrasted coeval magmas: example ofn the Tichka plutonic complex (Morocco). Contrib. Mineral Petrol. 116: 316-326.

FERRARI, A.L. 1996. Rifts. Seminário na disciplina Tectônica dos Continentes. IG/USP.

Programa de Pós- Graduação. 15p.

.FERRARI, A.L.; BRENNER, T.L.; DALCOMO, M.T.; NUNES, H.R.C. - 1982 - O PréCambriano das Folhas Itaboraí, Maricá, Saquarema e Baía da Guanabara. In Congresso Brasileiro de Geologia, 32, Salvador, 1982. Anais... Salvador, SBG, 1: 103-114.

FERREIRA, E.O. - 1972 - Explanatory note of the Tectonic Map of Brazil. Dep. Nac. Prod. Min., Boletim 1, Rio de Janeiro.

.FIGUEIREDO, M.C.H. - 1990 - Evolução geológica dos terrenos Costeiro, Paraíba do Sul e Juiz de Fora (Rio de Janeiro Minas Gerais e Espírito Santo). Anais do XXXVI Congresso Brasileiro de Geologia - Natal, RN - 6: 2631-2648.

FIGUEIREDO, M.C.H.; CAMPOS NETO, M.C. - 1993 - Geochemistry of the Rio Doce magmatic arc, Southeastern Brazil. An. Acad. Bras. Ciênc. 65 (Supl. 1): 63-81.

FIORI, A.P. - 1990 - Tectônica e Estratigrafia do Grupo Açungui à Norte de Curitiba. Universidade de São Paulo (Tese de Livre Docência - Instituto de Geociências/USP),
$261 \mathrm{p}$.

FIORI, A.P. - 1995a - As falhas da Lancinha e do Morro agudo e estruturas secundárias associadas. In Simpósio Sul Brasileiro de Geologia, 13, Florianópolis, 1995. Atas... Florianópolis, 1; 146-158.

FIORI, A.P. - 1995b - A falha da Lancinha no pré-cambriano paranaense: reflexo de uma falha profunda? Boletim Paranaense de Geociências 36: 3-14.

FIORI, A.P. - 1995c- Aplicação do modelo de cisalhamento simples na análise da deformação de alguns granitos paranaense. Boletim Paranaense de Geociências 36: 31-
40 .

.FONSECA, A.C. - 1986 - Geocronologia das rochas graníticas e suas encaixantes na cidade do Rio de Janeiro. São Paulo, Universidade de São Paulo. (Dissertação de Mestrado - Instituto de Geociências/USP) 281 p.

FONSECA, A.C.; CORDANI, U.G.; KAWASHITA, K. - 1984 - Dados preliminares sobre a Geocronologia das rochas graniticas e suas encaixantes na cidade do Rio de JaneiroMétodo Rb/Sr. In: Congresso Brasileiro de Geologia 33, Rio de Janeiro, 1984. Anais... Rio de Janeiro, 5, 2333-2345. 
FONSECA, M.J.G.; PEÇANHA, R.M.; JUNHO, M.C.B.; FRANCISCO, B.H.R.; DREHER, A.M. - 1998 - Mapa Geológico do Estado do Rio de Janeiro. Esc: 1:400.000. Brasília, DNPM: $141 p$.

FONSECA, M.J.G.; SILVA, Z.C.G.; CAMPOS, D.A.; TOSATTO, P.- 1979 - Texto Explicativo da Carta Geológica do Brasil ao Milionésimo, folhas Rio de Janeiro (SF23), Vitória (SF-24) e lguape (SG-23). Brasília, DNPM, 240p.

FOSSEN, H.; TIKOFF, B. - 1993 - The deformation matrix for simultaneous simple shearing, pure shearing and volume change, and its application to transpressiontranstension tectonics. J. Struct. Geol., $15(3 / 5)$ : 413-422.

FOSSEN, H.; TIKOFF, B.; TEYSSIER, C. - 1994 - Strain Modeling of Tranpressional and Transtensional Deformation. Norsk Geologisk Tidsskrift 74: 134-145.

FOURCADE, S. - 1981 - Géochimie des grainitoïdes. Thèse de doctorat, Paris, 189p.

FRAGOSO-CESAR, A.R.S. - 1991 - Tectónica de Placas no Ciclo Brasiliano: as Orogenias dos Cinturões Dom Feliciano e Ribeira no Rio Grande do Sul. Tese de Doutorado, Inst. Geoc., USP, 367p.

.FRAGOSO-CESAR, A.R.S., 1980 - O Cráton do Rio de La Plata e o Cinturão Dom Feliciano no Escudo Uruguaio-Sul-Riograndense. In Congresso Brasileiro de Geologia, 31, Balneário de Camboriú , 1982. Anais... Balneário de Camboriú, SBG, 5: 2879-2892.

FRAGOSO-CESAR, A.R.S., 1990 - Tectônica de Placas no bloco São Gabriel (RS) em base dos dados geológicos, geocronológicos e geoquímicos. In: Workshop de Geoquímica isotópica, geocronologia e litogeoquímica das regiões sul e sudeste do Brasil. Boletim de Resumos. São Paulo, SBG/IG-USP, 8-16.

.FRAGOSO-CESAR, A.R.S.; MACHADO, R.; WERNICK, E.; MCREATH, 1.; PHILLIP, R.P.; SALLET, R.; ENDO, I,; MELLO, F.M.; ALMEIRA, T.I.; SAYEG, H.S.; FAMBRINI, G.L.; SILVA FILHO, W.F.; DEHLER, N.M.; TEIXEIRA, A.L. - 1995 - The Brasiliania plate, the western Paranaides and the Eastern Atlantides and Africanides accreted terranes: a model for the Neoproterozoic tectonic collage of Southeastern South America. In: Simpósio Sul-Brasileiro de Geologia, 6, Encontro de Geologia do Cone Sul, 1, Porto Alegre, 1995. Atas...Porto Alegre, 20-26.

FRAGOSO-CESAR, A.R.S.-1993 - As placas brasilianas do Sul e Sudeste da plataforma sul-americana. in Simpósio Nacional de Estudos Tectônicos, 4, Belo Horizonte. Boletim... Belo Horizonte, 1993, 12: 183-188.

.FRANTZ, J.C.; NARDI, L.V.S. - 1992 - O magmatismo granítico da região oriental do escudo Sul-rio-grandense. Uma revisão. Pesquisas, 19 (2): 183-189.

.FROST, P.T.; MAHOOD, G.A. - 1987 - Field, chemical \& physical contraints of maficfelsic magma interaction in the Lamarck granodiorite, Sierra nevada, California. Bull. Geol. Soc. Am. 99: 272-291.

FYFE, W.S.; LEONARDOS JR., O.H. - 1974 - Ancient metamorphic migmatite belts of the brasilian Atlantic coast: the African connection. Rev. Bras. Geoc., 4 (4): 247-251.

GAPAIS, D.; BARBARIN, B. - 1986 - Quartz fabric transition in a cooling syntectonic granite (Hermitage Massif, France). Tectonophysics 125: $357-370$.

.GARCIA, M.G.M. - 1996 - Análise cinemática do setor de junção entre as zonas de cisalhamento direcionais São Bento do Sapucai, Jundiuvira e Setãozinho, nas imediações de Piracaia-SP. Universidade de São Paulo. (Dissertação de Mestrado - Instituto de Geociências/USP).

.GARCIA, M.G.M.; CAMPOS NETO, M.C. - 1996 - Evidências de inversão cinemática em zonas de cisalhamento direcionais na Faixa Ribeira, região de Piracaia-SP. In: Congresso Brasileiro de Geologia, 39., Salvador, SBG, 1:.442-444. 
GEYH, M.A.; SCHLEICHER, H. - 1990 - Absolute age determination. Physical and chemical dating methods and their application. 1 ed., New York Spring-Verlag, 503 p.

.GOMES, B.S.; BATISTA, J.J.; MARQUETTO, C.M.L. - 1978 - Folha São João do Paraíso. Proj. Carta Geológica do Rio de Janeiro. DRM / Triservice. Rio de Janeiro

GROMET, P.L.; SILVER, L.T. - 1987 - REE variations across the Peninsular Ranges batholith: implications for batholithic petrogenesis and crustal growth in magmatic arcs. $J$. Petrol. 28: $75-125$.

GROSSI SAD, J.H.; BARBOSA, A.L.M. - 1985 - A origem dos charnockitos e rochas afins na região do médio Paraíba do Sul, estado do Rio de Janeiro. Cont. Geol. Petrol., SBG/MG. Boletim Especial:, 15-28.

GROSSI SAD, J.H.; DUTRA - 1988 - Chemical composition of supracrustal rocks from Paraiba do Sul Group, Rio de Janeiro State, Brazil. Geoch. Bras. VII (2): 143-174.

GRANT, F.S.; WEST, G.F. - 1965 - Interpretation theory in appliedgeophysics. Imprenta: New York, Mc Graw-Hill, 1965: 584 p.

GUILLET, P.; BOUCHEZ, J.L.; WAGNER, J.J. - 1983 - Anisotropy of magnetic susceptibility and magmatic structures in the Guerande Granite Massif (France). Tectonics 2: 419-429.

GUILLET, P.; BOUCHEZ, J.L.; VIGNERESSE, J.L. - 1985 - Le complexe granitique de Plouaret (Bretagne): mise en évidence structurale et gravimétrique de diapirs emboîtés. Bull. Soc.géol.France, (8)t.l, 4: 503-513.

GUIMARÃES, I.P.; ALMEIDA, C.N.; SILVA FILHO, A.F.; ARAUJO, J.M.M. - $2000-$ Granitoids marking the end of the Brasiliano (Pan-African) Orogeny ithin the Central Tectonic Domain of the Borborema Province. In: Revista Brasileira de Geologia, SBG vol
(30)1: 177-181.

GUINEBERTEAU, B.; BOUCHEZ, J.L.;VIGNERESSE, J.L. - 1987-The Mortagne Granite Pluton (France) emplaced by pull-apart along a shear zone: structural and gravimetric arguments and regional implication. Geol. Soc. America Bull. 99:763-770.

HACKSPACHER, P. - 1996 - Tectônica transtensiva / transpressiva e alojamento de rochas plutônicas, à exemplo da folha Cabreúva (SP) 1: 50.000. Rio Claro, Universidade Estadual Paulista (Tese de Livre Docência - Instituto de Geociências/UNESP) 203 p.

HACKSPACHER, P.; GODOY, A.M.; OLIVEIRA, M.A.F. - 1991 - Estrutura e tectônica do cinturão de cisalhamento de cavalgamento / transcorrência do sudeste brasileiro. In Simpósio Nacional de Estudos Tectônicos 3, Rio Claro, 1991. Boletim...Rio Claro, SBG, 223-230.

.HACKSPACHER, P.; MORALES, N.; ZANARDO, A.; GODOY, A.M.; OLIVEIRA, M.A.F. 1992 - A tectônica transcorrente-transpressiva brasiliana da folha São Roque-SP. In: Congresso Brasileiro de Geologia 37, São Paulo, 1992. Boletim de Resumos
Expandidos...São Paulo, SBG, .2, 348-350.

HAMILTON, W.; MYERS, B. - 1967 - On the nature of batholiths. U. S. Geol. Surv. Prof. Paper 554: 30p.

HANMER, S. - 1986 - Asymetrical pull-aparts and foliation fish as kinematic indicators. Journal Structural Geology 8: 111-122.

HANMER, S.; VIGNERESSE, J.L. 1980. Mise en place de diapirs syntectoniques dans la chaîne hercynienne: exemple des massifs leucogranitiques de Locronan et de Pontivy

HARALYI, H.L.E; HASUI, Y,, 1982. Compartimentação geotectônica do Brasil oriental com base na informação geofísica. In: Congresso Brasileiro de Geologia 34, Salvador, 1 : 
HARALYI, N.L.E.; HASUI Y.; COSTA, J.B.S. - 1991 - Megaestruturação pré-cambriana do Território Brasileiro baseada em dados geofísicos e geológicos. In $3^{\circ}$ Simp. Nacional de Estudos Tectônicos Rio Claro, SBG, 146-147.

HARDING, T.P. - 1974 - Petroleum traps associated with wrench faults. Am. Ass. Petr. Geol. Bull. 58: 1290-1304.

HARGRAVES, R.B.; JOHNSON, D.; CHAN, C.Y, - 1991 - Distribuition anisotropy: the cause of AMS in igneous rocks? Geophs. Res. Lett. 18: $2193-2196$.

HARLAND, W.B. 1971. Tectonic transpression in Caledonian Spitsbergen. Geol. Mag. 108 (1): $27-42$

HARRIS, C. - 1986 - A quantitative study of magmatic inclusions in the plutonic ejecta of Ascension, Island. in J. of Petrology 27 (1): 251-276.

.HASUI, Y, HARALY, N.L.E; COSTA, J.B.S. - 1993 - Megaestruturação pré-cambriana do território brasileiro baseada em dados geofísicos e geológicos. Geociências, São Paulo, $12(1): 7-32$

.HASUY, Y.; CARNEIRO, C.D.R.; COIMBRA, A.M. - 1975 - The Ribeira Folded Belt, Revista Brasileira de Geociências 5(4): 257-266.

HEILBRON, M.L. - 1989 - Dados preliminares da faixa Bom Jardim de Minas(MG)Conservatória(RJ). $5^{\circ}$ Simpósio Geol. Minas Gerais. Anais. Bol.10: 218-222.

HEILBRON, M.L. - 1993 - Evolução Tectônico-metamónfica da seção Bom Jardim de Minas (MG)-Barra do Piraí (RJ). Setor central da Faixa Ribeira. (Tese de Doutorado Instituto de Geociências/USP), 268p.

HEILBRON, M.L. - 1995 - O segmento central da Faixa Ribeira: sintese geológicae ensaio de evolução geotectônica. Rio de Janeiro, Universidade Estadual do Rio de Janeiro (Tese de Livre Docência - Departamento de Geologia/Geofísica,/UERJ) 110 p.

.HEILBRON, M.L; SANTOS, R.O; VALLADARES, C.S.; VALERIANO, C.M. - 1992 Geologia e litogeoquímica do leoucogranito da Serra do Ipiranga. In Congresso Brasileiro de Geologia, 37, São Paulo, 1992. Boletim de Resumos Especiais... São Paulo, SBG, 1: 375-376.

.HEILBRON, M.L.; VALERIANO, C.M.; ALMEIDA, J.C.H.; VALLADARES, C.S.; MACHADO, N; TUPINAMBÁ, M. - 1995 - Segmento central da faixa Ribeira, exemplo de colisão continental obliqua no evento termo-tectônico brasiliano. In Congresso Brasileiro de Geologia, 38, Camboriú, 1995. Boletim de Resumos Expandidos... Camboriú, SBG, 1 : 263-265.

HEILBRON, M.L.; VALERIANO, C.M.; VALLADARES, C.S.; MACHADO, N.; ALMEIDA, J.C.H.; TUPINAMBÁ, M.; DUARTE, B.P. - 1996 - The brasiliano orogeny (590-520 Ma.) at the central segment of Ribeira belt, SE Brazil. In Congresso Brasileiro de Geologia, 39., Salvador, 1996. Anais...Salvador, SBG, 6: 107-109

.HEILBRON, M.L.; VALERIANO, C.M.; ALMEIDA, J.C.H.; TUPINAMBÁ, M. - 1991 - A megassinforma do Paraiba do Sul e sua implicação na compartimentação tectônica do Setor Central da Faixa Ribeira. Atas do // Simp. Geol. Sud. SBG/SP/RJ. São Paulo: 519 527.

HEILBRON, M.L. - 1990 - O limite entre as faixas de dobramentos Alto Rio Grande e Ribeira na seção geotransversal Bom Jardim de Minas (MG) - Barra do Piraí (RJ). In Congr. Bras. Geol. XXXVI, Natal, Anais... Natal, RN, SBG, 6: 2813-2826.

.HEILBRON, M.L.; POLÔNIA, J.; AIRES, J.R.; VALERIANO, C.M.; SZATIMARI, P. - 1995 - Modelagem física da deformação principal brasiliana no segmento central da Faixa Ribeira. Bol. Res. Exp. V Simp. Est. Tect.: 241-242.

HEILBRON, M.L.; VALERIANO, C.M.; ALMEIDA, J.C.H; TUPINAMBÁ, M; VALLADARES, C.S.; SILVA, L.G.E.; NAVA, D.B.; DIOS, F.B. - 1993 - Compartimentação 
tectônica e evolução geológica do segmento central da Faixa Ribeira, ao sul do Craton do São Francisco. In Simp. Sobre o Cráton do São Francisco, II, Salvador, Anais... Salvador, Bahia, SBG: 263-265.

HEILBRON, M.L.; TUPINAMBÁ, ALMEIDA, J.C.H.; VALERIANO, C.M.; VALLADARES, C.S.; DUARTE, B.P. - 1998 - New contraints on the tectonic organization and structural styles related to the Brasiliano collage of the central segment of Ribeira Belt, SE Brazil. In International Conference on Precambrian and craton tectonics, 1, Ouro Preto, 1998. Notas... 189p.: 15-17.

.HEILBRON, M.L.; VALERIANO, C.M.; ALMEIDA, J.C.H; VALLADARES, C.S.; TUPINAMBÁ, M. - 1994 - Segmento Central da Faixa Ribeira, exemplo de colisão continental oblíqua no evento termo-tectônico Brasiliano. Bol. Res. Expand. do XXXVIII Congr. Bras. Geol., SBG, Balneário de Camboriú, SC, 1: 263-265.

HEMBOLD, R. - 1967 - Resumo da geologia do Estado da Guanabara, acompanhando o mapa geológico 1: 50.000 . Relatório da Comissão de Especialista do CNPq, sobre Movimentos de encosta no estado da Guanabara e regiões circundantes. Apêndice $n^{\circ} \mathbf{5}$, 31-34. Rio de Janeiro.

.HEMBOLD, R.; VALENÇA, J.G.; LEONARDOS Jr., O.H. - 1965 - Mapa Geológico do Estado da Guanabara, escala 1: 50.000. DNPM / MME.

HIBBARD, M.J. - 1987 - Deformation of incompletely cristallized magma systems: granitic gneisses and their tectonic implications. J. Geol. 95: 543-561.

.HIGGINS, M.W. - 1971 - Cataciastic rocks. U. S. Geol. Sun. Prof. Pap. 687.

.HINE, R.; WILLIAMS, I.S.; CHAPPELL, B.W.; WHITE, A.J.R. - 1978 - Contrast between 1and S-type granitoids of the Kosciusko batholith. J. Geol. Soc. Aust. 25: 219-234.

.HIPPERT, J.F.M. - 1990 - Contribuição à geologia e petrologia dos "augen" gnaisses de Niterói, RJ. Universidade de São Paulo (Dissertação de Mestrado - Instituto de Geociências/USP) 203 p.

HOBBS, B.E.; MEANS, W.D.; WILLIAMS, P.F. - 1976 - An outline of Structural Geology. New York, John Wiley, $571 \mathrm{p}$.

HOLDER, M.T. - 1979 - An emplacement mechanism for post-tectonic granites and its implications for their geochemical features. In: Origin of Granite Batholiths: Geochemical Evidence (Edited by Atherton M.P.\& Tarney, J.). Shiva Publications Ltd. Cheshire, 116128.

HOLDER, M.T. - 1981 - Some aspects of intrusion by ballooning: the Ardure pluton (abstract). in: Diapirism and Gravity Tectonics: Report of a tectonic Studies Group (edited by. Coward. M. P.) J. Struct. Geol. 3, 89-95.

.HORN, H.; WEBER-DIEFENBACH, K. - 1987 - Geochemical and genetic studies of three invers zoned intrusive bodiesof both alkaline and calc-alkaline composition in the Ribeira Mobile Belt (Espírito Santo, Brazil). Revista Brasileira de Geociências 17 (4): 488-497.

HROUDA, F. - 1982-Magnetic Anisotropy of Rocks and its application in geology and Geophysics. Geophysical Surveys 5: 37-82.

.HROUDA, F; JANAK, F. - 1976 - The in shape of the magnetic susceptibility ellipsoid during progressive metamorphism and deformation. Tectonophysics 34: 135-148.

HUNTER, R.H. - 1996 - Texture development in cumulate rocks. Layered intrusions Elsevier Science, $77-101$

HUTTON, D.H.W. - 1982 - A method for the determination of the initial shapes of deformed xenoliths in granitoids Tectonophysics 85: 45-50.

HUTTON, D.H.W. - 1988b - Igneous emplacement in shear zones termination: the biotite granite at Strontian, Scotland. Bull. Geol. Soc. Am. 100: 1392-1399. 
interection between deformational and solidification processes. Geol.Soc.America Bull., 105: 213-230.

KAUL, P.F.T. - 1984 - Significado dos granitos anorogênicos da Suite intrusiva Serra do Mar na evolução da crosta sul-sudeste do Brasil, no âmbito das folhas SG-22- Curitiba e SG-23- Iguape. In: Congresso Brasileiro de Geologia, 38, Rio de Janeiro, 1984. Anais... Rio de Janeiro, SBG, 33: 371-373.

KAUL, P.F.T.; CORDANI, U.G. - 2000 - Geochemistry of the Serra do Mar granitoid magmatism and tectonic implications, southern Brazil. In: Revista Brasileira de Geologia, SBG, (30)1: 115-119.

KERRICK, R.I.; ALLISION, R.L.; BARNETT, S.M.; STARKEY, J. - 1980 - Microstructural and chemical transformations accompanying deformation of granite in a shear zone at Mieville, Switzerland: with implications for stress corrosion cracking and superplastic flow. Contr. Miner. Petrol 73: 221-242.

KOESTER, E. - 1995 - Evolução geológica do magmatismo sintectônico à Zona de Cisalhamento Transcorrente Dorsal de Canguçu, Região de Encruzilhada do Sul, RS. Dissertação de mestrado, Curso de Pós-Graduação em Geociências, UFRGS 240.

KOESTER, E; SOLIANI Jr., E.; FERNANDES, L.A.D.; NARDI, L.V.S.; KRAMER, G. 1995 - Posicionamento de granitóides cálcico-alcalnos e peraluminosos sintectônicos à Zona de Cisalhamento Transcorrente Dorsal de canguçu, Encruzilhada do Sul, RS. In $V$ Simpósio Nacional de Estudos Tectônicos, Gramado-RS. Atas ... Gramado, RS: 197-198.

.LA TOUR; T.E. - 1987 - Geochemical model for the symplectic formation of myrmekite during amphibole-grade progressive mylonitization granite. Geol. Soc. Am. Abs. W. Prog. 19, p. 741.

.LACROIX, S.; SAWYER, E.W.; CHOWN, E.H. - 1998 - Pluton emplacement within na extensional transfer zone during dextral strike-slip faulting: na exemple from the late Archaean Abitibi Greenstone Belt. Journal of Structural Geology. 20 (1): 43-59.

.LAGARDE, J.L.; CAPDEVILA, R.; FOURCADE, S. - 1992 - Granites et collision continentale: l'exemple des granitoïdes carbonifères dans la chaîne hercynienne ouesteuropéenne. Bull. Soc. géol. France, t.163, 5: 597-610.

LAGARDE, J.L.; CHOUKROUNE, P. - 1982 - Cisaillement ductile et granitoïdes syntectoniques: l'exemple du massif hercynien des Jebilet (Maroc). Bull. Soc. géol. France (7), t.24, 2: 299m307.

LAMEGO, A.R. - 1937 - Theoria do protogneis. Boletim do Serv.Geol. Miner., DNPM, 86, $73 \mathrm{p}$.

LAMEGO, A.R. - 1938 - Escarpas do Rio de Janeiro. Boletim do Serv. Geol. Miner, DNPM, 93, 1-72.

LAMEGO, A.R. - 1946 - Análise tectônica e morfológica do Sistema da mantiqueira. Congr. Panamer. Eng. De Minas e geologia 2, Petrópolis, Anais... 3., 247-326.

.LAMEGO, A.R. - 1948 - Folha Rio de Janeiro. Bol. 126, DNPM / DGM, Rio de Janeiro. $16 \mathrm{p}$.

LAMEYRE, J.; BOWDEN, P.- 1982 - Plutonic rocks types series: discrimination of various granitoid series and related rocks. J. Volcanol. Geotherm. Res. 14: 169-186.

.LAMOUROUX, C.H.; SOULA, J.C.; DERAMOND, J.; DEBAT, P. - 1980 - Shear zones in granodiorite massifs of the central Pyrenees and the behaviour of these massifs during the Alpine Orogenisis. J. Struct. Geol. 2: 49-53.

LANZIROTTI, A.; HANSON, G.N. - 1995 - U-Pb dating of major and acessory minerals formed during metamorphism and deformation of metapelites. Geoch. Cosm. Acta 59 (2): 2513-2526. 
HUTTON, D.H.W. -1988a - Granite emplacement mechanisms and tectonic controls: inferences from deformation studies. Trans. R. Soc. Edinb. Earth Sci. 79: 245-255.

.HUTTON, D.H.W. 1992. Granite sheeted complexes: evidence for the dyking ascent mecanism. Transactions of Royal Society of Edinburg: Earth Sciences 83: 377-382.

.HUTTON, D.H.W. 1995. A general solution to the space problem in granite emplacement. Boletim de Resumos Expandidos do V Simp. Nacional de Estudos Tectônicos, Gramado RS: p. 194.

.HUTTON, D.H.W.; INGRAM, G.M. - 1992 - The Great Tonalite Sill of southeastern Alaska and British Columbia: emplacement into an active contracional high angle reverse shear zone (extended abstract). Trans. Ro. Soc. Edin: Earth Sciences, 83: 383-386.

.HUTTON, D.H.W.; REAVY, R.J.- 1992 - Strike-slip and granite petrogenesis. Tectonics 11: $960-967$.

IRVINE, T.N.; BARAGAR, W.R.A. - 1971 - A guide to the chemical classification of the common volcanic rocks. Canadian Journal of Earth Sciences 8: 249-302.

.JACKSON, M.P.A.; TALBOT, C.J. - 1989 - Anatomy of mushroom-shaped diapirs. J.Struct.Geol. 11: 211-230.

.JANASI, V. A.; ULBRICH, H.H.G.J. - 1991 - Late Proterozoic granitoid magmatism in the State of São Paulo, Southeastern Brazil. Prec. Res. 51: 351-374.

JARDIM DE SÁ, E.F. - 1984 - Geologia da região do Serdó: reavaliação dos dados. In XI Simp. Geol. Nordeste, Natal, Atas...Natal, 278-296.

.JARDIM DE SÁ, E.F.; FUCK, R.A.; HOLLANDA, M.H.B.M. - 1995 - Alojamento de granitóides em regimes de trancorrência dúctil: exemplos do Nordeste do Brasil. In Simpósio Nacional de Estudos Tectônicos, 5, Gramado RS, 1995. Boletim de Resumos Expandidos... Gramado RS, SBG, 195-196.

JINESCU, V.V. - 1974 - The rheology of suspensions. International Chemical Engineering, 14: 397-420.

.JOHANNES, W.; HOLTZ, F. - 1991 - Formation and ascent of granitic magmas. Geol. Rundschau, 80/2, 225-231.

.JUNHO, M.C.B. - 1982 - Geologia, petrografia e geoquímica preliminar do granito de Teresópolis, RJ. Rio de Janeiro, Universidade Federal do Rio de Janeiro. (Dissertação de Mestrado - Instituto de Geociências/ UFRJ) 90 p.

.JUNHO, M.C.B. - 1991 - Contribuição à Petrologia dos maciços graníticos da Pedra Branca, Frades e Nova Friburgo, Rio de Janeiro. Rio de Janeiro, Universidade Federal do Rio de Janeiro. (Tese de Doutorado - Instituto de Geociências/UFRJ) 198 p.

JUNHO, M.C.B. - 1993 - Granitóides brasilianos da região central do Estado do Rio de Janeiro - Geoquímica preliminar. An. Acad. Bras. Ciênc. 65 (2): 161-179.

.JUNHO, M.C.B.; PENHA, H.M.- 1985 - Geologia e Geoquímica dos granitos de Teresópolis, RJ. An. Acad. Bras. Ciênc. 57: 54 - 62.

.JUNHO, M.C.B.; RIVALENTI, G.; MENDES, J.; LUDKA, I.; TROUW, R.A.J. - 1998 - O gabro de Miguel Pereira, SW do Rio de Janeiro: química de rocha e mineral. In Congresso Brasil. Geol., XXXIX, Belo Horizonte, SBG, Anais...BH: p. 481.

.JUNHO, M.C.B.; WEBER-DIFENBACH, K.; WIEDEMANN, C.; PENHA, H.M. - 1987 Major and minor elements geochemistry of Pedra Branca, Frades and Nova Friburgo granitic complexes, Ribeira Mobile Belt, RJ, Brazil. Rev. Bras. Geoc. 17 (4): 507-511.

JUNHO, M.C.B.; WIEDEMANN, C. - 1987 - Petrografia comparativa de três complexos intrusivos da província granítica do Estado do Rio de Janeiro. Simpósio de Geologia Regional RJ / ES, Rio de Janeiro, 1987. Anais...Rio de Janeiro, 120-131.

KARLSTROM, K.E.; MILLER, C.F.; KINGSBURY, J.A.; WOODEN, J.L. - 1993 - Pluton emplacement along an active ductile thrust zone, Piute Montains, southeastern California: 
interection between deformational and solidification processes. Geol.Soc.America Bull., 105: 213-230.

KAUL, P.F.T. - 1984 - Significado dos granitos anorogênicos da Suite intrusiva Serra do Mar na evolução da crosta sul-sudeste do Brasil, no âmbito das folhas SG-22- Curitiba e SG-23- Iguape. In: Congresso Brasileiro de Geologia, 38, Rio de Janeiro, 1984. Anais... Rio de Janeiro, SBG, 33: 371-373.

KAUL, P.F.T.; CORDANI, U.G. - 2000 - Geochemistry of the Serra do Mar granitoid magmatism and tectonic implications, southern Brazil. In: Revista Brasileira de Geologia, SBG, (30)1: 115-119.

.KERRICK, R.I; ALLISION, R.L.; BARNETT, S.M.; STARKEY, J. - 1980 - Microstructural and chemical transformations accompanying deformation of granite in a shear zone at Mieville, Switzerland: with implications for stress corrosion cracking and superplastic flow. Contr. Miner. Petrol 73: 221-242.

.KOESTER, E. - 1995 - Evolução geológica do magmatismo sintectônico à Zona de Cisalhamento Transcorrente Dorsal de Canguçu, Região de Encruzilhada do Sul, RS. Dissertação de mestrado, Curso de Pós-Graduação em Geociências, UFRGS 240.

KOESTER, E; SOLIANI Jr., E.; FERNANDES, L.A.D.; NARDI, L.V.S.; KRAMER, G. 1995 - Posicionamento de granitóides cálcico-alcalnos e peraluminosos sintectônicos à Zona de Cisalhamento Transcorrente Dorsal de canguçu, Encruzilhada do Sul, RS. In V Simpósio Nacional de Estudos Tectônicos, Gramado-RS. Atas ... Gramado, RS: 197-198.

. LA TOUR; T.E. - 1987 - Geochemical model for the symplectic formation of myrmekite during amphibole-grade progressive mylonitization granite. Geol. Soc. Am. Abs. W. Prog. 19, p. 741.

LACROIX, S.; SAWYER, E.W.; CHOWN, E.H. - 1998 - Pluton emplacement within na extensional transfer zone during dextral strike-slip faulting: na exemple from the late Archaean Abitibi Greenstone Belt. Journal of Structural Geology. 20 (1): 43-59.

LAGARDE, J.L.; CAPDEVILA, R.; FOURCADE, S. - 1992 - Granites et collision continentale: l'exemple des granitoïdes carbonifères dans la chaîne hercynienne ouesteuropéenne. Bull. Soc. géol. France, t.163, 5: 597-610.

.LAGARDE, J.L.; CHOUKROUNE, P. - 1982 - Cisaillement ductile et granitoïdes syntectoniques: l'exemple du massif hercynien des Jebilet (Maroc). Bull. Soc. géol. France (7), t.24, 2: 299-307.

LAMEGO, A.R. - 1937 - Theoria do protogneis. Boletim do Serv.Geol. Miner., DNPM, 86, $73 \mathrm{p}$.

.LAMEGO, A.R. - 1938 - Escarpas do Rio de Janeiro. Boletim do Serv. Geol. Miner., DNPM, 93, 1-72.

.LAMEGO, A.R. - 1946 - Análise tectônica e morfológica do Sistema da mantiqueira. Congr. Panamer. Eng. De Minas e geologia 2, Petrópolis, Anais... 3., 247-326.

LAMEGO, A.R. - 1948 - Folha Rio de Janeiro. Bol. 126, DNPM / DGM, Rio de Janeiro. $16 \mathrm{p}$.

LAMEYRE, J.; BOWDEN, P.- 1982 - Plutonic rocks types series: discrimination of various granitoid series and related rocks. J. Volcanol. Geotherm. Res. 14: 169-186.

.LAMOUROUX, C.H.; SOULA, J.C.; DERAMOND, J.; DEBAT, P. - 1980 - Shear zones in granodiorite massifs of the central Pyrenees and the behaviour of these massifs during the Alpine Orogenisis. J. Struct. Geol. 2: 49-53.

.LANZIROTTI, A.; HANSON, G.N. - 1995 - U-Pb dating of major and acessory minerals formed during metamorphism and deformation of metapelites. Geoch. Cosm. Acta 59 (2): 2513-2526. 
LE MAITTRE, R.W. - 1989 - A classification of igneous rocks and glossary of terms: recommendations of the International Union of Geological-Sciences Subcommmission on the systematics of igneous rocks. Blackwell, Oxford, $193 \mathrm{p}$.

.LEAKE, B..E; WOOLLEY, A.R.; ARPS, C.E.S.;BIRCH, W.D.; GILBERT, M.C.;GRICE, J.D.; HAWTHORNE, F.C.; KATO, A.; KISCH, H.J.; KRIVOVICHEV, V.G.; LINTHOUT, K.; LAIRD, J.; MANDARINO, J. - 1997 - Nomenclature of amphiboles: report of the subcommittee on amphiboles of International Mineralogical Association Commission on new minerals and minerals names. Mineralogical Magazine 61 (2): 295-321.

.LEDENT, D.; PASTEELS, P. - 1968 - Déterminations de l'âge des roches posttectoniques du sud-est du Brésil. Ann. Soc. Géol. Belg. 91: 305-309.

LEJEUNE, A.M.; RICHET, P. - 1995 - Rheology of crystal-bearing silicate melts: an experimental study of high viscosities. Journal of Geophysical Research 100: 4215-4229.

.LEONARDOS Jr., O.H. - 1973 - The origin and alteration of granitic rocks in Brazil: a study of metamorphism, anatexis, weathering and fertility within granitic terrains in eastern Brazil. (PhD Thesis - University of Manchester, England) $183 p$.

LESQUER, A.; ALMEIDA, F.F.M.; DAVINO, A.; LACHAUD, J.C; MAILARD, P. - 1981 Signification structurale des anomalies gravimétriques de la partie sud du Craton du São Francisco (Brésil). Tectonophysics 76: 273-293.

.LILLESAND, T.M.; KIEFER, R.W. - 1994 - Remote Sensing and Image Interpretation. 3 ed. John Wiley \& Sons, Inc. New York. 750p.

LIMA, E.F.; NARDI, L.V.S. - 1992 - O magmatismo shoshonítico no Estado do Rio Grande do Sul. Uma revisão. Pesquisas 19 (2): 190-194.

LISTER, G.S.; SNOUKE, A.W. - 1984 - S-C mylonites. J.Struct. Geol., 617-638.

.LISTER, G.S.; WILLIANS, P.F. - 1979 - Fabric development in shear zones: theorical controls and observed phenomena. J. Structural Geology 4(4): 283-297.

.LOCZY, L.; LADEIRA, E.A. - 1976 - Geologia Estrutural e Introdução à Geotectônica. Editôra Edgard Blücher / CNPq, Rio de Janeiro, 528p.

MACHADO FILHO, L; RIBEIRO, M.W.; GONZALES, S.R.; SCHEMIMI, C.A.; SANTO NETO, A.; PALMEIRA, R.C.B.; PIRES, J.L.; TEIXEIRA, W.; CASTRO, H.E. - 1983 Projeto RADAMBRASIL, Folhas Rio de Janeiro / Vitória (SF-23/24) (Levantamento de Recursos Naturais). 32: 29-304.

MACHADO, N.; KOPPE, J.C.; HARTMANN, C.A. - 1988 - Upper Proterozoic zircon age from Bossoroca Complex, RS. In: Conference International Geochemisty Evolution Crustal, Poços de Caldas, 1988. Abstract...Poços de Caldas, Brasil, 305.

MACHADO, N.; VALLADARES, C.; HEILBRON, M.L.; VALERIANO, C.M. - 1996 - U-Pb geochronology of the central Ribeira Belt (Brazil) and implications for the evolution of the Brazilian Orogeny. Precambrian Research 79: 347-361.

MACHADO, R. - 1983 - Considerações sobre a estruturação tectônica divergente da porção ocidental do Estado do Rio de Janeiro. In Simpósio Regional de Geologia, 4., São Paulo, 1983. Atas... São Paulo, 135-145.

MACHADO, R. - 1984 - Evolução Geológica, Análise Estrutural e Metamórfica da Região de Vassouras e Paracambi, Porção Ocidental do Estado do Rio de Janeiro. Tese de Doutoramento. Tese de Doutorado - Instituto de Geociências / USP, 196 p.

MACHADO, R. - 1990 - Batólito Serra do Órgãos: uma entidade plutônica cálcio-alcalina sin-colisional de arco magmático brasiliano do cinturão Ribeira no Rio de Janeiro. In: Congresso Brasileiro de Geologia, 36., Natal, 1990. Boletim de Resumos... Natal, SBG, p. 221. 
MACHADO, R. - 1997 - Litogeoquímica e tectônica dos granitóides Neoproterozóicos do Cinturão Paraíba do Sul no Estado do Rio de Janeiro. Tese de Livre-Docência. Instituto de Geociências / Universidade de São Paulo, $215 p$.

MACHADO, R.; DEMANGE, M. - 1990 - Reinterpretação estrutural e tectônica da região a Leste da Baía da Guanabara e a definição do Batólito de Araruama. In Congresso Brasileiro de Geologia 36., Natal, 1990. Anais... Natal, SBG, 6, 2744-2754.

MACHADO, R.; DEMANGE, M. - 1991 - Contexto tectônico e estrutural dos granitóides brasilianos do Estado do Rio de Janeiro. In: Simposio Nacional de Estudos Tectônicos, 3 Rio Claro-1991. Boletim de Resumos Expandidos. Rio Claro, SBG, 64-65.

MACHADO, R.; DEMANGE, M. - 1992 - Granitogênese brasiliana no Estado do Rio de janeiro. Caracterização geoquímica, modelo tectônico e considerações geológica sobre o embasamento e a cobertura do cinturão Ribeira na região. In Congresso Brasileiro de Geologia, 37, São Paulo, 1992. Boletim de Resumos Expandidos... São Paulo, SBG, 1: 379-380.

MACHADO, R; DEMANGE, M. - 1994a - Classificação estrutural e tectônica dos granitóides Neoproterozóicos do Cinturão Paraíba do Sul no Estado do Rio de Janeiro. Boletim do IG-USP, Série Cient. 25: 81-96.

MACHADO, R.; DEMANGE, M. - 1994a - O Batólito Corditheirano Serra dos Órgãos: um exemplo de arco magmático brasiliano com assinatura tolética no Sistema de Cisalhamento Paraiba do Sul, no estado do Rio de Janeiro. In Congresso Brasil. Geol., XXXVIII, Balneário de Camboriú, SBG, Anais...1: 114-115.

MACHADO, R.; DEMANGE, M. - 1998 - Caracterização geoquímica e tectônica dos granitóides pré-colisionais Neoproterozóicos do Cinturão Paraíba do Sul no Estado do Rio de Janeiro, In (Conceição, H. ed.) Contribuição ao estudo dos granitos e rochas correlatas. Soc. Bras. Geol., Núcleo BA-SE, Publ. Esp. 5: 21-39

MACHADO, R.; DEMANGE, M.; MONTEIRO, R.L. -1989a - Granitóides do Estado do Rio de Janeiro: nível estrutural de colocação e suas relações com as fases de deformação e com o grau de metamorfismo. In: I Simpósio de Geologia do Sudeste, Rio de Janeiro, núcleos RJ/SP. Boletim de Resumos... Rio de Janeiro, 145-146.

MACHADO, R.; DEMANGE, M.; PELLOGIA, A.G.; MONTEIRO, R.L. -1989b - Rochas graníticas e charnockiticas do Estado do Rio de Janeiro: associações petrográficas e suas relações com os domínios estruturais. In: Simpósio de Geologia do Sudeste, 1, Rio de Janeiro, núcleos RJ/SP. Boletim de Resumos... Rio de Janeiro, 151-152.

MACHADO, R.; DEMANGE, M.; VIALLETE, Y - 1996 - Idades geocronológicas Rb/Sr da granitogênese brasiliana no segmento setentrional da Faixa Ribeira, Estado do Rio de Janeiro. In: Congresso Brasileiro de Geologia, 39., Salvador, SBG, 1: 38-40.

MACHADO, R.; ENDO, I.- 1993a - O Cinturão de Cisalhamento Atlântico: um exemplo de tectônica transpressional neoproterozóica. In Simpósio Nacional de Estudos Tectônicos, 4. Belo Horizonte, 1993. Boletim..., Belo Horizonte, 188-191.

MACHADO, R.; ENDO, l.- 1993b- A megaestrutura em flor positiva do vale do rio Paraiba do Sul no Rio de Janeiro. In: Simpósio de Geologia do Sudeste, 3, Rio de Janeiro, 1993. Atas...Rio de Janeiro, 208-213.

MACHADO, R.; OLIVEIRA, M.A.F. - 1986 - Evolução textural e metamórfica de rochas de médio e alto grau da região de Vassouras e Valença. Estado do Rio de Janeiro. In Congresso Brasileiro de Geologia XXXIV, Goiânia, 1986. Anais..., Goiânia, SBG, 4: 15261540. 
MACHADO, R.; PELOGGIA, A.U.G. - 1987 - Mapa de distribuição das rochas granitóides do Estado do Rio de Janeiro: uma avaliação preliminar das informações disponíveis. Simpósio Regional de Geologia, 4., Rio Claro, 1983. Atas... Rio Claro 1: 93-96.

MACHADO, R.; DEMANGE, M. 1994. Classificação estrutural e tectônica dos granitóides neoproterozóicos do Cinturão Paraíba do Sul no estado do Rio de Janeiro. Bol.IG-USP, Série Científica 25: 81-96.

MACHADO, R.; DEMANGE, M.; MCREATH, I.; MOUTTE, J. - 2000 - Crustal zoning of Neoproterozoic pre-collisional granitoids in the Paraiba do Sul Belt, Rio de Janeiro, Brazil. In Revista Brasileira de Geologia, SBG, (30)1: 70-73.

MACHADO, R.; ENDO, I. 1989. Cinturão de Cisalhamento Atlântico: Um exemplo de Tectônica Transpressional Neoproterozóica. Anais. IV Simp. Est.Tect. Nucleo MG, Bol.12: 189-191.

MACHADO, R.; ENDO, I. -1993 - Estruturas transcorrentes na borda sul do Cráton do São Francisco: uma interpretação. Anais do // Simp.do C.S.F., Salvador: 269-271.

MAFRA, C.Q.T;; SILVA, P.C.F.; CAMPANHA, G. - 1996 - A estruturação do embasamento cristalino na região de São Sebastião, SP: evidências de um domínio transpressivo. In: Congresso Brasileiro de Geologia, 39., Salvador, SBG, 1: 385-387.

MAINPRICE, D.; BOUCHEZ, J.L.; BLUMENFELD, P. - 1986 - Dominant C slip in naturally deformed quartz: implications for dramatic plastic softening at high temperature. Geology 14: 819-822.

MANIAR, P.D.; PICCOLI, P.M. - 1989 -Tectonic discrimination of granitoids. Geol. Soc. Am. Bull. 101: 635-643.

MARRE, J. - 1982 - Méthodes D'Analyse structurale des granitö̈des. Manuels et méthodes 3 - Bureau de recherches géologiques et minières, BRGM - Orleans, 119p.

MARRE, J. - 1986 -The structural Analysis of Granitic Rocks. Elsevier, Amsterdam. 123p. MARSH, B.D. - 1982 - On the mechanics of igneous diapirism, stoping and zone melting. Amer. J.Sci. 282: 808-855.

MASQUELIN, H. - 1990 - Análise estructural de las zonas de cizalla en las migmatitas de Punta del Este-Uruguay. Acta Geológica Leopoldensia 13 (30): 139-158.

MATOS, G.M.M.; FERRARI, P.G.; CAVALCANTE, J.C. - 1980 - Projeto Faixa Calcária Cordeiro-Cantagalo. Belo Horizonte, DNPM/CPRM, 620p.

MCCAFFREY, K.J.W. - 1992 - Igneous emplacement in a transpressive shear zones: Ox Montains igneous complex. J.Geol.Soc. London 149: 221-235.

MENEZES, S.O.; CORDANI, U.G.; TEIXEIRA, W. - 1987 - Determinações geocronológicas em pegmatitos do Estado do Rio de Janeiro. In Simpósio de Geologia RJ-ES, 1, Rio de Janeiro, 1987. Anais... Rio de Janeiro, SBG, 147-165.

MEZGER, K.; RAWNSLEY, C.M.; BOHLEN, R.; HANSON, G.N. - 1990 - U-Pb garnet, sphene, monazite and rutile ages: implications for the duration of hih-grade metamorphism and cooling histories, Adirondack Mts., New York. J. Geol. 99: 415-428.

MIDDLEMOST, E.A.K. - 1980 - A contribution to the nomenclature and classification of volcanic rocks. Geol. Mag. 117 (1): 51-57.

MILLER, C.F.; WATSON, E.B.; HARRISON, T.M. - 1988 - Pespectives on the source, segregation and transport of granitoid magmas. Trans. Royal Soc. Ed. 79: 135-156.

MILLER, R.B.; PATERSON, S.R. - 1999 - In defense of magmatic diapirs. Journal Structural Geology 21(1999):1161-1173.

MANIAR, P.D.; PICOLLI, P.M. - 1989 - Tectonic discrimination of granitoids. Geol. Sc. Of Am. Bull 101: 635-643.

MOORE, N.D.; AGAR, R.A. - 1985 - Variations along a batholith: the Arequipa segment of the Coatal batholith of Peru. In: Pitcher, W.; Atherton, M.P.; Cobbing, E.J.; Beckinsale, 
R.D. (eds.): Magmatism at a Plate Edge: the Peruvian Andes. John Wiley and Sons, 108118.

MORAES REGO, L.F.- 1930 - A geologia do petróleo no estado de São Paulo. Bol. SGM, (46); Rio de Janeiro: 105p.

MYASHIRO, A- 1974 - Volcanic rock series in Island arcs and active continental margins. Am. J. Sci., 274: 321-355.

NACHIT, H.; RAZAFIMAHEFA, N.; STUSSI, J.M.; CARRON, J.P. 1985 - Composition chimique des biotites et typologie magmatique des granitoïdes. C.R. Acad. Sci. Paris 301 (II), 11: 813-818.

.NACHIT, H. - 1986 - Contribuition à l'étude analytique et des biotites des granitoïdes. Aplications typologiques. Tese. Brest, 93p.

NALINI Jr., H.A.; BILAL, E.; CORREIA NEVES, J.M. - 2000 - Syn-collisional peraluminous magmatism in the Rio Doce region: mineralogy, geochemistry and isotopic data of the Neoproterozoic Urucum Suite (eastern Minas Gerais State, Brazil). In Revista Brasileira de Geologia, SBG (30)1: 120-125.

NASLUND. H.R.; MCBIRNEY A.R. - 1996 - Mechanisms of formation of igneous layering. Layered Intrusions, Elsevier Science, $1-43$.

NUMMER, A.R.; FERREIRA, A.D. - 1994 - Coluna tectonoestratigráfica do Domínio Paraíba do Sul entre a Serra das Araras e a llha da Madeira, oeste do estado do Rio de Janeiro. Anais do XXXVIII Congresso Brasileiro de Geologia, Camboriú, SC, 2: 53-54. NUMMER, A.R. - 1991 - Análise Estrutural e estratigrafia do Grupo Andrelândia na Região de Santa Rita do Ibitipóca-Lima Duarte, sul de Minas Gerais. Boletim de Resumos da I/ Bienal de pesquisa da UFRRJ, Rio de Janeiro.

.NUMMER, A.R. - 1991 - Modelamento de uma megaestrutura do Grupo Andrelândia na Região de Santa Rita do Ibitipóca - Lima Duarte. Anais da I/ Bienal de pesquisa da UFRRJ, Rio de Janeiro.

NUMMER, A.R. - 1990 - Estratigrafia e estruturas do Grupo Andrelândia na Região de Santa Rita do Ibitipóca - Lima Duarte, sul de Minas Gerais. Anais do 36 C.B.G., Natal, RN; 6: 2786-2797.

NUMMER, A.R. - 1992 - Mapeamento geológico litoestrutural e tectônica experimental do Grupo Andrelândia na região de Santa Rita do Ibitipóca - Lima Duarte, sul de Minas Gerais. Tese de Mestrado IG - Universidade Federal do Rio de Janeiro - Rio de Janeiro $200 \mathrm{p}$.

NUMMER, A.R;; PRAZERES, M.N.; PACHECO, E.A.; ALBUQUERQUE, K.R.M.; MORAES, E.O. - 1995 - Transpressão e granitóides sintectônicos da região de Arrozal, oeste do Estado do Rio de Janeiro. In Simpósio Nacional De Estudos Tectônicos, 5, Gramado, 1995. Boletim de Resumos Expandidos...Gramado, 295-207.

NUMMER, A.R.; SEIXAS, L.A.R.; BAARS, F.J.; ALMEIDA, M.E.; FERREIRA, A.L.; MARTINS, A.P.S.; MONTEIRO, M.A.S.; PAIXÃO, M.A.P.; SIROTHEAU, G.J.C.; TASSO, M.A.L. - 1992 - Geologia Estrutural e Petrologia do Lineamento Congonhas, Minas Gerais. Anais do XXXVII Congresso Brasileiro de Geologia, São Paulo; vol. 2.

O'HARA, K.; GROMET, L.P. - 1985 - Two distinct late Precambrian (Avalonian) terranes in southeastern New England and their Late Paleozoic juxtaposition. Am. J. Sci. 285, 673709.

OLIVEIRA, M.A.F. - 1980 - Petrologia das rochas granuliticas da faixa Paraíba do Sul, Estados do Rio de Janeiro e Minas Gerais. Tese de livre docência ao Inst. Geoc. e Cien. Exatas, Univ. Est. Paulista, Rio Claro, SP: 196p. 
OLIVER, H.W. - 1977 - Gravity and magnetic investigations of the Sierra Nevada Batholith, California. In Bull. Geological Society of America 88 (3): 445-461.

PABST, A. - 1928 - Observations on inclusions in the granitic rocks of the Sierra nevada. Univ. Calif. Publs. Geol. Sci. 17: 325-386.

PARRISH, R.R.- 1990 - U-Pb dating of monazite and its application to geological problems. Can. J. Earth Sci. 27: 1431-1450.

.PASSARELLI, C.R. - 1996 - Análise estrutural e caracterização do magmatismo da zona de cisalhamento Major Gercino. Universidade de São Paulo, (Dissertação de Mestrado Instituto de Geociências/USP) 179p.

.PASSARELLI, C.R.; BASEI, M.A.S. - 1995 - Análise dos petrotramas de eixos-c de quartzo: zona de cisalhamento Major Gercino (SC). Boletim do /G-USP, Série Cient. 26: 99-113.

PATERSON, S.R.; FOWLER,T.K. - 1993 - Re-examining pluton emplacement processes. Jour. Struct. Geology 15(2):191-206.

PATERSON, S.R.; MILLER, R.B. - 1998a - Magma emplacement during arcperpendicular contraction. Tectonics 17: 571-586.

PATERSON, S.R.; MILLER, R.B. - 1998b - Mid-crustal magmatic sheets in the cascades Mountains, Washington: implications for magma ascent. J. Struct. Geol. 20: 1345-1363.

.PATERSON, S.R.; SCHMIDT,K.L. - 1999 - is there a close spatial relationship between faults and plutons? Journal Structural Geology 21(1999): 1131-1142.

PATERSON, S.R.; TOBISH, OT. - 1988 - Using pluton ages to date regional deformations: problems with commonly used criteria. Geology 16: 1108-1111.

PATERSON, S.R.; VERNON, R.H.; FOWLER, Jr. T.K. - 1994 - Aureole tectonics In Reviews in Mineralogy, 26 - Contact Metamorphism Cap. 13 - Miner. Society of America, (Paul H.Ribbe ed).

.PATERSON, S.R.; VERNON, R.H.; FOWLER, T.K. - 1991 - Aureole tectonics. In Reviews in Mineralogy (edited by Kerrick, D.M.) Book Crafters, 673-722.

PATERSON,S.R.; FOWLER,T.K. - 1993 - Re-examining pluton emplacement processes. Jour. Struct. Geology 15:191-206.

PATERSON, S.R.; VERNON, R.H.; TOBISCH, O.T. - 1989 - A review of criteria for the identification of magmatic and tectonic foliations in granitoids. Journal Structural Geology, 11: 349-363.

PATTERSON, S.R.; FOWLER Jr. T.K.; SCHMIDT, K.L.; YOSHINOBU, A.S.; YUAN, E.S.; MILLER, R.B. - 1998 - Interpreting magmatic fabric patterns in plutons . Lithos 44 (1998): 53-82.

.PEACOCK, M.A. -1934 - Classification of igneous rock series. J. Geol. 39: 54-67.

.PEARCE, J.A.; HARRIS, N.B.W.; TINLDLE, A.G.- 1984 - Trace element discrimination diagrams for the tectonic interpretation of granitic rocks. J. Petrol. 25 (4): 956-983.

.PEDROSA-SOARES, A.C., HOCE, C.M., VIDAL, P.; MONTEIRO, R.L.B.P.; SALAZAR, E. - 1992 - Toward a new tectonic model for the Late-Proterozoic Araçuai (SE Brazil) - West Congolian (SW Africa) belt. J. South Am. Earth Sc. 6 (1/2): 33-47.

PENHA, H.M.- 1984 - Granitóides da região central do Estado do Rio deJaneiro:uma síntese dos conhecimentos existentes. In Congresso Brasileiro de Geologia, 33., Rio de Janeiro, 1984. Anais... Rio de Janeiro, SBG, 6,: 2849-2853.

PENHA, H.M.; FERRARI, A.L.; RIBEIRO, A.; AMADOR, E.S.; PENTAGNA, F.P.; JUNHO, M.C.B.; BRENNER, T.L. - 1979 - Projeto Carta Geológica do Estado do Rio de Janeiro, Folha Petrópolis. Rio de Janeiro. Convênio DRM/UFRJ, Relatório final, 194p.

PENHA, H.M.; FERRARI, A.L.; RIBEIRO, A.; AMADOR, E.S.; PENTAGNA, F.V.P.; JUNHO, M.C.B.; BRENNER, T.L. - 1980 - A Geologia da Folha Petrópolis. In XXXI 
Congresso Brasileiro de Geologia, Camboriú, 1980. Anais... Camboriú, SBG, 5: 29652974.

PENHA, H.M.; WIEDEMANN, C.M. - 1984 - Granitóides da região central do Estado do Rio de Janeiro. In XXXIII Congresso Brasileiro de Geologia, Rio de Janeiro, 1984. Roteiro de Excursões. Rio de Janeiro, SBG, 5433-5456.

PETFORD, N. ATHERTON, M. - 1992 - Granitoid emplacement and deformation along a major crustal lineament the Cordillera Blanca, Peru. In Tectonophysics 205 (1/3): 171 185.

PHILIPP, R.P.; MESQUITA, M.J.M.; GOMES, M.E.B.; ALMEIDA, D.P.M. - 1992 Reconhecimento estrutural e geoquímico dos granitóides brasilianos da região de Pelotas, RS. Pesquisas 20 (1): 3-13.

PIDGEON, R.T; BOSCH, D.; BRUGUIER, O. - 1996 - Inherited zircon and titanite U_Pb systems in an Archean syenite from Southwestern Australia: implications for U-Pb stability of titanite. Earth Planet. Sci. lett. 141: 187-198.

PINET, N.; COBBOLD, P.R. - 1992- Experimental insights into the partitioning of motion within zones of oblique subduction. Tectonophysics 206: 371-388

PIRES, R.M.; VALENÇA, J.G.; RIBEIRO, A. - 1982 - Multistage generation of granite in Rio de Janeiro, Brazil. An. Acad. Bras. Ciênc. 54 (3): 563-574

PITCHER, W. - 1978 - The anatomy of a batholith. J. Geol. Soc. London, 135, 157-182.

PITCHER, W. - 1979b - The nature, ascent and emplacement of granite magmas. J. Geol. Soc. Lond. 136: 627-662.

PITCHER, W. - 1982 - Granite type and tectonic enviroment. In: K. HSU (Ed.): Mountain Building Processes. Academic Press, 19-40.

PITCHER, W. - 1987 - Granites and yet more granites forty years. Geol. Rundschau 76/1: 51-79.

PITCHER, W.; ATHERTON, M.P.; COBBING, E.J.; BECKINSALE, R.D. - 1985 - A model for the Coastal batholith. In Pitcher, W.; Atherton, M.P.; Cobbing, E.J.; Beckinsale, R.D. (eds.). Magmatism at a Plate Edge: the Peruvian Andes. John Wiley and Sons, 239-240. PITCHER, W.S.; BERGER, A.R. - 1972 - The Geology of Donegal: Study of Granite Emplacement Unroofing. Jon Wiley, London.

POIRIER, J.P.; GUILLOPE, M. - 1979 - Deformation induced recrystallization of minerals. In $B$. de Mineralogie 102 (2/3): 67-74.

.PORCHER, C.C.; FERNANDES, L.A.D. - 1997 -Metamorphic evolution of a lower crustal trascurrent shear zone: the Três Rios- Além Paraíba Lineament. In V/ Simpósio Nacional de Estudos Tectônicos, Atas... :85-87.

.PORCHER, C.C. - 1997 - Relações entre metamorfismo e deformação na Faixa Ribeira: regiões de Três Rios e Santo Antônio de Pádua. Tese de Doutorado ao IG - UFRGS,
Porto Alegre, RS:

.PORTO Jr., R.; DUARTE, B.P.; VALENTE, S.C. - 1992 - Processos de diferenciação magmática atuantes na formação da fácies hololeucocrática do granito Pedra Branca, maciço da Pedra Branca, Rio de Janeiro, RJ. In Congresso Brasileiro de Geologia, 38., Natal, 1994. Anais... Natal, SBG, 6: 2744-2754.

PORTO Jr., R. - 1995 - Caracterização dos granitos da Faixa Ribeira na porção correspondente à cidade do Rio de Janeiro, RJ, Brasil. In IX Congresso Latinoamericano de Geologia Caracas, Ministério de Energia y Minas, 225p., Caracas: 18-19.

.PORTO Jr., R.; SANCHEZ, B.; MEIGHAN,I.G.; FALLICK, A.E. - 1996 - RJ - Geologia, geoquímica e gecronologia do batólito Serra dos Órgãos. In Congresso Brasileiro de Geologia 38., Salvador, 1996. Anais...Salvador, SBG, 6: 445-448. 
PUGET, A.J.F.; PENHA, H.M. - 1980 - Granitos da região de Ipiranga, Magé, RJ considerações geoquímicas e petrológicas. In Congresso Brasileiro de Geologia, 31. Camboriú, 1980. Anais... Camboriú, SBG, 4: 2215-2229.

PUNKHUST, R.J. - 1979 - Isotope and trace element evidence for the origin end evolution of Caledonian granites in the Southern Highlands. In Atherton, M.P and Tarney (eds.): Origen of Granite Batholiths: Geochemical Evidence. Shiva Publ. Ltda, 18-33.

.RACIOT, D.; CHOUN, E.H.; HAMEL, T. - 1984 - Plutons of ChibougamauDesmaraisville belt: a preliminary survey Chibougamau- Desmaraisville and Mineralization. Canad. Inst. Mining and Metall. Spec. 34: 178-197.

RAGATKY, D.; TUPINAMBÁ, M; DUARTE, B.P. - $2000-\mathrm{Sm} / \mathrm{Nd}$ data of metasedimentary rocks from the central segment of Ribeira belt, southeastern Brazil. In: Revista Brasileira de Geologia, SBG (30)1: 165-168.

.RAMBERG, H. - 1981 - Gravity, deformation and the Earth's crust in theory, experiments and geological appplications. Academic Press, London.

.RAMSAY, J.G. - 1981 - Emplacement mechanics of the Chindamer Batholith, Zimbabwe (abstract). In Diapirism and Gravity Tectonics: Report of a tectonic Studies Group (edited by. Coward. M. P.) J. Struct. Geol. 3: 89-95

.RAMSAY, J.G.; GRAHAM, R.H. - 1970 - Strain variation in shear belts. Can.J.Earth Sci. 7: 786-813

RATHORE, J.S.; KAFAFY, A.M. - 1986 - A magnetic fabric study of the Shap region in the English Lake district. J. Struct. Geol. 8: 69-77.

REESOR, J.E. - 1958 - Dewar Creek map area with special emphasis on the White Creek Batholith, British Columbia. Geol. Surv. Canada Mem. 292.

REGGO, I.T.S.F. - 1989 - Petrologia e geoquímica da unidade charnockítica Bela Joana, região de São Fidélis, RJ, São Paulo, Universidade de São Paulo (Tese de Doutoramento - Instituto de Geociências /USP) 348 p.

REGO, I.T.S.F; FIGUEIREDO, M.C.H. - 1991 - Geoquímica da unidade charnockítica Bela Joana, região de São Fidélis, Rio de Janeiro. In Congresso Brasileiro de Geoquimica, 3., Congresso de Geoquímica dos Paises de Lingua Portuguesa 1, São Paulo, 1991. Boletim de Resumos... São Paulo, 1: 231-233.

.REGO, I.T.S.F.; FIGUEIREDO, M.C.H. - 1994 - Geoquímica da Unidade Angelim, região de São Fidélis, Rio de Janeiro. In Congresso Brasileiro de Geologia, 38, Camboriú, 1994. Boletim de Resumos Expandidos... Camboriú, SBG, 3: 153-154.

.REIS NETO, J.M. - 1994 - Faixa Itaiacoca: Registro de uma colisão entre dois blocos continentais no Neoproterozóico. São Paulo, Universidade de São Paulo ( Tese de Doutoramento - Instituto de Geociências/USP) 253 p.

REIS NETO, J.M.; CORDANI, U.G. - 1993 - Características geoquímicas e isotópicas dos complecos Três Córregos e Cunhaporanga: implicações tectônicas. Simpósio Internacional del Neoproterozóico-Cambrico de la Cuenca del Plata, 1, La Paloma-Minas, Uruguai. Resumenes Extensos... La Paloma-Minas, Tomo II.

REIS, A.P.; CASTRO, H.O.; DALCOMO, M.T.; FERRARI, A.L.; MEL, F.; NEVES, L.F.L.; VAZ, M.A.A.; SILVA, V.P.; NASSAR, W.M. - 1982a - Geologia das Folhas Morro do Côco, Barra Seca, Itabapoama, Travessão, São João da Barra, Campos, Muçurepe, Lagoa Feia e Farol de São Tomé, RJ. In Congresso Brasileiro de Geologia, 32., Salvador, 1982. Anais...Salvador, SBG, 1: 75-85.

REIS, A.P.; CASTRO, H.O.; PUGET, A.J.F.; BARBOSA, A.L.M.; LIMA, E.C.V.; RIBEIRO, A.C.; PINTO, C.P.; DUTRA, J.E.B.; GROSSI SAD, J.H. - 1982 - Geologia das Folhas Três Rios, Paraíba do Sul, Miguel Pereira e Cava-RJ. In Congresso Brasileiro de Geologia, 32., Salvador, 1982. Anais... Salvador, SBG, 1: 94-102. 
REIS, A.P.; ROCHA, R.L.S.; BARBOSA, A.L.M.; LIMA, E.C.V.; SAD, J.H.; ALVES, M.R.; BALTAZAR, O.F. - 1982b - Geologia das Folhas Varre-Sai, Eugeonópolis, Itaperuna e Miracema. RJ. In XXX/l Congresso Brasileiro de Geologia 32, Salvador, 1982. Anais... Salvador, SBG, 1: 86-93.

RIBEIRO, M; FANTINEL, L.M. - 1978 - Associações petrotectônicas do Escudo Sul-RioGrandense: tabulação e distribuição das associações petrotectônicas do Escudo do Rio Grande do sul. Lheringia, Sér. Geol. 5, Porto Alegre, 19-54.

RICHARD, P. - 1989 - Champs de failles au dessu d'un decrochement de socle. Modelisation experimentale. Thèse de Doctorat, Université de Rennes I, Rennes (França). 342 p.

.RICHARD, P.; COBBOLD, P. - 1990 - Experimental insights into partitioning of fault motions in continental convergent wrench zones. Ann. Tectonicae 4: 35-44.

RIEDEL, W. - 1929 - Zur Mechanik geologischer Brucherscheinung: Centralbl. Für Mineralogie. Geologie und Paläeontologie, 1929B: 354-368.

.RIFFAS, A.C.G. - 1996 - A zona de cisalhamento sinistral "Sierra Ballena" no Uruguai. São Paulo, Universidade de São Paulo (Tese de Doutoramento - Instituto de Geociências/USP) $221 \mathrm{p}$.

ROIG, H.L.; SCHRANK, A., 1992. Caracterização da zona de sutura Jacui-Conceição limite norte do complexo de nappes do Guaxupé-MG. In Congresso Brasileiro de Geologia, 37, São Paulo, 1992. Boletim de Resumos Expandidos...São Paulo, SBG, 1: 283-285.

.ROSIER, G.F. - 1957 - A geologia da serra do mar entre os picos de Maria Comprida e Desengano (Estado do Rio de Janeiro). Bol. Div. Geol. e Min., RJ (166): 1-58.

ROSIER, G.F. - 1965 - Pesquisas geológicas na parte oriental do estado do Rio de Janeiro e na parte vizinha do estado de M.Gerais. Bol. Div. de Geol. e Min., RJ (222): 1-4.

ROSIER, G.F.- 1957 - Pesquisas geológicas na parte oriental do Estado do Rio de Janeiro. Bol. Div. Geol. Min., DNPM, Rio de Janeiro, 222p.

RUBIN, A.M. - 1995 - Getting granite dikes out of the source region. Journal of Geophysical Research 100: 5911-5929.

.RUIZ, M.; COSTA, A.; RAPOSO, F.O. - 1983 - Projeto Carta geológica do Estado do Rio de Janeiro: folhas Santa Rita do Jacutinga, Volta Redonda, Resende, Barra Mansa, Liberdade, Bananal, Passa Quatro, Agulhas Negras, São José do Barreiro, Nossa Senhora do Amparo. Convênio CPRM/DRM. Relatório Final, Niterói, 7 volumes.

.SAD, J.H.G.; BARBOSA, A.L.M. - 1985 - A origem dos charnockitos e rochas afins da região do médio Paraíba do Sul, Estado do Rio de Janeiro. Bol. Especial, Núcleo de Minas Gerais, SBG, Belo Horizonte, 15-27.

SAD, J.H.G.; BARBOSA, A.L.M. - 1988 - Chemical compositions of supracrustal rocks from Paraíba do Sul Group, Rio de Janeiro State, Brazil. Geochimica Brasiliensis, 2 (2): 143-165.

SAD, J.H.G.; DUTRA, C. - 1988 - Chemical composition of supracrustal rocks from Paraíba do Sul Group, Rio de Janeiro State, Brazil. Rev. Bras. Geoc., 7 (2): 143-174.

.SAD, J.H.G.; MOREIRA, M.D.; FIGUEIRAS, R.R.; ARANTES, D. - 1980a - Projeto Carta Geológica do Estado do Rio de Janeiro. Escala 1:50.000. Folha Trajano de Morais: texto explicativo e mapa geológico. Niterói, DRM/RJ, 132p.

SAD, J.H.G.;PINTO, C.P.; SERPA, J.C.; DUTRA, J.E.B; HETTICH, M.; ANDRADE, N.E1980 b - Projeto Carta Geológica do Estado do Rio de Janeiro. Escala 1:50.000. Folhas Anta, Duas Barras, Terezópolis e Nova Friburgo: Texto explicativo e mapa geológico.
Niterói, DRM/RJ. 
SADOWSKI, G.R. - 1983 - Sobre a geologia estrutural de cinturões de cisalhamento continentais. Universidade de São Paulo (Tese de Livre Docência - Instituto de Geociências/USP) 108p.

SADOWSKI, G.R. - 1991 - A megafalha de Cubatão no sudeste brasileiro. Boletim do Inst. Geoc., USP, Série Cient. 22: 15-28.

SADOWSKI, G.R.; MOTIDOME - 1992 - Brazilian megafaults. Rev. Geol. Chile 31: 61-75. SANCHEZ, B.; PORTO JR.R.; MEIGHAN, I.G.; FALLICK, A.E. - 1995- Aspectos petrográficos e geoquímicos do batólito da Serra dos Órgãos, RJ, Brasil. In Congresso de Geoquímica de Países de Língua Portuguesa, 2, Niterói, 1995. Anais... Niterói-RJ, SBGq (CD-ROM).

SANDERSON, D.J.; MARCHINI, W.R.D. 1984. Tranpression. Journal Structural Geology 6(5): 449-458.

SCHMIDT-THOME, R.; WEBER-DIFENBACH, K. - 1987 - Evidence for "frozen-in" magma mixing in Brasiliano calc-alkaline intrusions: the Santa Angélica pluton, southern Espírito Santo, Brazil. Rev. Bras. Geoc. 17 (4): 498-506.

.SENGÖR, A.M.C.- 1990 - Plate tectonics and orogenic research after 25 years: a Tethyan perspective. Earth Sci. Rev., 27 (1/2): 1-201.

.SIGA Jr., O.; TASSINARI, C.T.; SCHMUS, W.R.V. - 1989 - Caracterização geocronológica de maciços charnockíticos do sudeste brasileiro. In Simpósio de Geologia do Sudeste, 1, Rio de Janeiro, 1989. Boletim de Resumos...Rio de Janeiro, Núcleos RJ/SP, 90-91.

.SIGA Jr., O.; TEIXEIRA, W.; CORDANI, U.G.; KAWASHITA, K.; DELHAL, J. - 1982 - O padrão geológico - geocronológico das rochas de alto grau da parte setentrional da Faixa Ribeira, Norte do Rio de Janeiro, Brasil. In V Congresso Latino-americano de Geologia, AR, 1982. Actas Serbiço Geológico Nacional 1: 349-370.

SILVA, L.G.E.; NAVA, D.B.; HEILBRON, M.; VALERIANO, C.M. - 1991 - Geologia de detalhe da Serra da Carioca, cidade do Rio de Janeiro. In Simpósio de Geologia do Sudeste, 2, São Paulo, 1991.Atas..., São Paulo, SBG, 161-170.

SILVA, M.E. - 1981 - Análise estrutural das faixas ectiniticas associadas ao falhamento de Cubatão entre as regiões de Juquiá e Pedro Barros, Estado de São Paulo. São Paulo, Universidade de São Paulo (Dissertação de Mestrado - Instituto de Geociências/USP) $118 p$.

SILVA, M.E. - 1996 -Zona de cisalhamento de alta temperatura - o lineamento de Além Paraiba (RJ) (Petrotrama de plagioclásio - Anisotropia física - Reologia da litosfera continental. São Paulo, Universidade de São Paulo (Tese de Livre-Docência - Instituto de Geociências/USP) $226 \mathrm{p}$.

SILVA, M.E.; SADOWSKI, G. R.; TROMPETTE, R.R. - 1982 - Modelo geométrico e cinemático para os falhamentos de idade brasiliana da Faixa de Dobramentos Ribeira, Estado de São Paulo, Brasil. In Congresso Latino Americano de Geologia, Buenos Aires 1982. Anais...Buenos Aires, tomo II: 11-21.

SILVA, P.C.F.; SILVA, R.R.- 1987 - Mapeamento geológico-estrutural da Serra da Carioca e adjacências, Município do rio de janeiro. In Simpósio de Geologia do Sudeste, 1., Rio de Janeiro, 1987. Anais... Rio de Janeiro, SBG, Núcleos RJ/ES, 198-209.

SILVER, L.T.; CHAPPELL, B.W. - The Peninsular Ranges Batholith: an insight into the evolution of the Cordilleran batholiths of soutwestern North America. Trans. Royal Soc. Ed.: Earth Sci., 79: 105-121.

SIMPSON, C. -1985 - Deformation of granitic rocks across the brittle-ductile transition. J. Struct. Geol. 7: 503-511. 
SIMPSON, C.; SCHIMID, S.M. - 1983 - An evaluation of criteria to deduce the shear sense of movement in sheared rocks. Geol. Soc. Am. Bull. 94: 1281-1288.

.SIMPSON, C.; WINTSCH, R.P. - 1985 - Evidence of deformation-induced K-feldspar remplacement by myrmekite. J. Metam. Geol.

SMITH, J.V. - 1999 - Structures on interfaces of mingled magmas, Stewart Island, New Zealand. Journal Structural Geology 22 (2000): 123-133.

.SOARES, P.C. - 1988 - Tectônica colisional em torno do bloco Paraná, Brasil. In Congresso Latino Americano de Geologia, 7, Belém, 1988. Anais... Belém, SBG, 1: 63-79. .SOARES, P.C., FIORI, A. P.; CARVALHO, S.G. - 1990 - Tectônica colisional oblíqua entre o bloco Paraná e a margem sul do cráton São Francisco. In Congresso Brasileiro de Geologia, 36, Natal. 1990. Boletim de Resumos Expandidos...Natal-RN, SBG, 6, 27232734.

SOARES, P.C.; FIORI, A.P.; CARMIGNANI, L.; ROSTIROLLA, S.P. - 2000- A geotectonic view of the Ribeira and Dom Feliciano belts. In Revista Brasileira de Geologia, (30)1 SBG, 130-134.

SOARES, P.C.; ROSTITOLLA, S.P. - 1997 - Tectônica de escape tardicolisional nos Cinturões Ribeira e Dom Feliciano. In VI Simpósio nacional de Estudos Tectônicos, Itatiaia, RJ. 1997. Boletim de Resumos Expandidos...Itatiaia-RJ, SBG, 65-67.

.SOLIANI Jr., E. - 1986 - Os dados geocronológicos do Escudo Sul Riograndense e suas implicações de ordem geotectônica. São Paulo, Universidade de São Paulo (Tese de Doutoramento - Instituto de Geociências / USP) 239 p.

SÖLLNER, F; LAMMERER, B.; WEBER-DIEFENBACH, K.; HANSEN. B.T.- 1987 - The brasiliano orogenesis: age determinations (Rb-Sr and $\mathrm{U} / \mathrm{Pb}$ ) in the coastal mountains region of Espírito Santo, Brazil. Zentr. Geol. Paläontol. Teil I H 7/8: 729-741.

SOPER, N.J.; HUTTON, D.H.W. - 1984 - Late Caledonian sinistral displacements in Britain: implications for a three-plate collision model. Tectonics 3: 781-794.

SPEER, J.A 1987 - American Mineralogist 72: 863-878

SPERLING, E.V.; BALTAZAR, O.F.; VIEIRA, V.S. - 1983 - Projeto Carta Geológica do Estado do Rio de Janeiro. Folhas Mangaratiba, llha Grande, Angra dos Reis, Rio Mambucaba, Campos de Cunha, Parati, Cunha, Picinguaba, Juatinga e Cunhambebe. Convênio CPRM/DRM, Rel. Final, Niterói, 5 vol.

STACEY, F.D. - 1960 - Magnetic anisotropy in igneous rocks. J. Geophys. Res. 65: 2429 $-2442$.

STEIGER, R.H.; JAEGER, E. - 1977- Subcommission on geochronology: convention on the use of decay constants in geo- and cosmo-chronology. Earth Plan. Let. 36: 359-362.

STRACHAN, R.A.; HOLDSWORTH, J.D.; FRIDERICHSEN, J.D.; JEPSEN, H.F. - 1992 Regional Caledonian structure within an oblique convergence zone, Dronning Louise Land, NE Greenland. J. Geol. Soc., London 149: 359-371.

STREICKEISEN, A. - 1974 - How should charnockitic rocks be named ? Centenaire de la Soc. Géol. Bélgique - Géologie des domaines cristallins, Liége, 4: 239-249.

.STREICKEISEN, A. - 1976 - To each plutonic rocks its proper nome. Earth Sci. Rev. 12 : 1-33.

STUSSI, J.M.; CUNEY, M. - 1996 - Nature of biotites from alkaline, calc-alkaline and peraluminous magmas by Abdel-Fattah Mabdel-Rahman: a comment. Journal fo Petrology 37 (5): 1025-1029.

.SYLVESTER, A.G.; SMITH, R.R. - 1976 - Tectonic transpression and basementcontrolled deformation in San Andreas fault aones. Salton trough, Califórnia. Am. Ass. Petrol. Geol. Bull. 60: 2081-2102. 
TAMRAT, E.; ERNESTO, M. - 1999 - Magnetic fabric and rock-magnetic character of the Mesozoic flood basalts of the Paraná Basin, Brazil. Journal of Geodynamics 28 (1999):
419-437.

TAPONIER, P.; MOLNAR, P.- 1976 - Slip-line field theory and large-scale continental tectonic. Nature 264, 319-324.

TAPONIER, P.; MOLNAR, P.- 1979 - Active faulting and cenozoic tectonics of the Tien Mongolia and Baykal regions. J. Geoph. Res. 84 B7: 345-349.

.TAPONIER, P.; MOLNAR, P.; ARMIJO, R. - 1976 - On the mechanics of the collision between India and Asia. Geol. Soc. London, Sp. publ. 19: 115-158.

-TASSINARI, C.G. - 1988 - As idades das rochas e dos eventos metamórficos da porção sudeste do estado de São Paulo e sua evolução crustal. São Paulo, Universidade de São Paulo (Tese de Doutoramento - Instituto de Geociências/USP) 236 p.

TCHALENCO, J.S. - 1970 - Similarities between shear aones of different magnitudes. Am. Ass. Petrol. Geol. Bull. 81: 1625-1640.

TIKOFF, B.; BLANQUAT, M.S.; TEYSSIER, C. - 1999 - Translation and the resolution of the pluton space problem. Journal Structural Geology 21(1999):1109-1117.

TIKOFF, B.; TEYSSIER, C. - 1992-Crustal-scale, en échelon 'P-shear' tensional bridges: A possible solution to tha batholithic room problem. Geology 20: 927-930.

TIKOFF, B.;TESSIER, C. - 1994 - Strain moddeling of displacement field partitioning in transpressional orogens. Journal of Structural Geology 16 (11): 1575-1588.

TOMMASI, A.; FERNANDES, L.A.D.; PORCHER, C.C.; VAUCHEZ, A. - 1992 - Evolução cinemática das porções internas do cinturão Dom Feliciano, região de Piratini, RS.

Pesquisas 19 (2): 143-154.

TRELOAR, P.J.; STRACHAN, R.A.-1990 - Cadomian strike-slipe tectonics in NE Brittany. In: (D'LEMOS, R.S.D.; STRACHAN, R.A.; TOPLEY, C.G. eds.) The Cadomian orogenesis: Geol. Soc. Spec. Publ. 51: 151-168.

TROMPETTE, R. - 1994 - Geology of the Western Gondwana (2000 - 500 My) PanAfrican - Brasiliano aggregation of South America and Africa. A.A. Balkema, Rotterdam,
XII- 350 p.

TROMPETTE, R.; SILVA, M.E.; VAUCHEZ, A.; TOMMASI, A. - 1998 - Amalgamação do Gondwana ocidental no Panafricano-Brasiliano e o papel da geometria do cráton do São Francisco na arquitetura da Faixa Ribeira. Rev. Bras. Geoc. 23 (3): 187-193.

TROUW, R.A.J. - 1992 - Evolução tectônica ao sul do Craton de São Francisco, baseada em análise metamórfica. In XXXVII Congresso Brasileiro de Geologia, São Paulo. Anais... São Paulo, SBG: p. 327.

TROUW, R.A.J. - 1995 - Uma avaliação de modelos cinemáticos propostos para a megassinformal do Vale do Rio Paraíba do Sul baseado em lineações de estiramento. In Simpósio Nacional de Estudos Tectônicos 5, Gramado. Anais... Gramado, SBG: 103-104. TROUW, R.A.J.; PANKHUST, R.J. - 1993 - Idades radiométricas ao sul do cráton do São Francisco: região da Folha de Barbacena, Minas Gerais. In: Simpósio sobre o Craton do São Francisco 2, Salvador, 1993. Anais... Salvador, Bahia, 260-263.

TUCKER, R.D.; RAHEIM, A.; KROGH, T.E.; CORFU, F. - 1987 - Uranium-lead zircon and titanite ages from the northern portion of the Western gneiss region, South-Central
Norway. Earth Planet. Sci. Lett. 81: 203-211.

TULLIS, J.A. - 1983 - Deformation of feldspars. In: Feldspar mineralogy (edited by Ribbe, P. H.). Mineral. Soc. Am. Short Course Notes 2: 297-323.

TUPINAMBÁ, M. - 1993 - Rochas intrusivas e metassedimentos granulíticos do Complexo Paraíba do Sul na parte setentrional da Faixa Ribeira. In III Simpósio de Geologia do Sudeste, SBG, Rio de Janeiro. Atas. Rio de Janeiro. 
TUPINAMBÁ, M. - 1999 - Evolução Tectônica e Magmática da Faixa Ribeira na Região Serrana do Estado do Rio de Janeiro. Tese de Doutorado no Programa PG GeoquimicaGeotectônica -IG-USP, São Paulo, 221p.

.TUPINAMBÁ, M.; HEILBRON, M.; OLIVEIRA, A.; PEREIRA, A.J.; CUNHA, E.R.S.P.; FERNANDES, G.A.; FERREIRA, F.N.; CASTILHO, J.G.; TEIXEIRA, W. - 1996 - O Complexo Rio Negro - uma unidade estratigráfica relevante no entendimento da evolução da Faixa Ribeira. In Congresso Brasil. Geol., XXXIX, Belo Horizonte, SBG, Anais.. BH: $\mathrm{p}$. 481

.TUPINAMBÁ, M.; TEIXEIRA, W.; HEILBRON, M. - 2000 - Neoproterozoic western Gondwana assembly and subduction-related plutonism: the role of the Rio Negro Complex in the Ribeira belt. In: Revista Brasileira de Geologia, SBG (30)1: 7-11.

.TUPINAMBÁ, M.; TEIXEIRA, W.; HEILBRON, M.; BASEI, M. - 1998a - U/Pb zircon age and litogeochemistry of the Rio Negro Complex tonalitic gneiss: evidence of a $630 \mathrm{Ma}$ magmatic arc at the Costeiro Domain of the Ribeira Belt.. In Congresso Brasil. Geol., $X X X I X$, Belo Horizonte, SBG, Anais...BH: p. 51.

TUPINAMBÁ, M.; TEIXEIRA, W.; HEILBRON, M.; BASEI, M. - 1998b - The Pan-African / Brasiliano arc-related magmatism at the Costeiro Domain at the Ribeira Belt, southeastern Brazil. In International Conference on Basement Tectonics 14: 12-14.

.TUPINAMBÁ, M.; TROUW, R.A.J. - 1994 - Evidências de evolução metamórfica e estrutural anterior à tectônica transpressiva na Faixa Ribeira. In $X X X V I I I$ C.B.G., SBG, Camboriú, SC. Anais..., 3:75.

TURNER, F.J.; WEISS, L.E. - 1973 - Structural analysis of metamorphic tectonites. New York, McGraw Hill, $545 \mathrm{p}$.

TUTTLE,O F.; BOWEN, N.L. - 1958 - Origin of granite in the light of experimental studies in the system $\mathrm{NaAlSi}_{3} \mathrm{O}_{8}-\mathrm{KalSi}_{3} \mathrm{O}_{8}-\mathrm{H}_{2} \mathrm{O}$ : Geol. Soc.America Mem. 74:153 p.

UHLEIN, A.; EGYDIO SILVA, M.; VAUCHEZ, A.; BOUCHEZ, J.L. - 1998 - Belo Horizonte, SBG, Núcleo MG: $p 47$.

.UYEDA,S.; FULLER,M.D.; BELCHE,J.C.; GIRDLE,R.W. - 1963 - Anisotropy of magnetic susceptibility of rocks and minerals. J.Geophys. Res. 68: 279-291.

VALENTE, S.C.; PORTO Jr, R.; DUARTE, B.P. - 1991 - Geologia do Pontal de Guaratiba: implicações petrogenéticas relacionadas ao batólito da Serra da Pedra Branca, Rio de Janeiro, RJ. In Simpósio de Geologia do Sudeste, 2., São Paulo, 1991. Atas...São Paulo, SBG,SP/RJ, 83-90.

VALLADARES, C. - 1996 -Evolução geológica do Complexo Paraíba do Sul, no segmento central da Faixa Ribeira, com base em estudos de geoquimica e geocronologia $U-P b$. São Paulo, Universidade de São Paulo, (Tese de Doutorado - Instituto de Geociências/USP) $147 p$.

VALLADARES, C.; HEILBRON, M.; FIGUEIREDO, M.C.H. - 1995 - O granito Getulândia e sua relação com a zona de cisalhamento Taxaquara. In Simpósio Nacional de Estudos Tectônicos, 5, Gramado, 1995. Boletim de Resumos... Gramado, SBG, p. 217.

VALLADARES, C.S.; DUARTE, B.P.; HEILBRON, M.L.; RAGATKY, D. - 2000 - The tectono-magmatic evolution of the occidental terrane and the Paraiba do Sul klippe within the Neoproterozoic Ribeira Orogenic Belt, southeastern. In Revista Brasileira de Geologia, SBG (30)1: 1-6.

VALLADARES, C.S.; HEILBRON, M.L.; FIGUEIREDO, M.C.H. - 1995 - O granito Getulândia e sua relação com a Zona de Cisalhamento Taxaquara. In $V$ Simpósio Nacional de Estudos Tectônicos,Gramado. Anais..., Gramado, SBG, 217-218. 
VALLADARES; C.S.; DUARTE, B.P.; HEILBRON, M, RAGATKY, D. - 2000 - Tectonomagmatic evolution of the western terrane and the Paraiba do Sul Klippe of the Neoproterozoic Ribeira Orogenic Belt, Southeastern Brazil. Revista Brasileira de Geociências volume 30 (1,2 e 3) Cd version. IGC 009.

VAN DER MOLEN, I; PATERSON, M.S. - 1979 - Experimental deformation of partially melted granite. Contr. Miner. Petrol. 70: 299-318.

VAUCHEZ, A. - 1980 - Ribbon texture and deformation mechanisms in quartz in a mylonitized granite of Great Kabylia (Algeria). Tectonophysics 67: 1-2.

VAUCHEZ, A. - 1987 - Mécanismes de déformation et cinématique des zones de mouvement ductiles. Thése Doctorale. Université d'Aix-Marseille.

VAUCHEZ, A; NICOLAS, A. - 1991 - Montain building: strike-parallel motion and mantle anisotroppy. Tectonophysics, 185 (3/4): 183-201.

VAUCHEZ, A; TOMMASI, A.; EGYDIO DA SILVA, M. - 1994 - Self-indentation of a heterogeneous continental lithosphere. Geology, 22: 967-970.

VAUCHEZ, A.; TOMMASI, A.; EGYDIO DA SILVA, M.; TROMPETTE, R. - 1992 Tectônica de escape na terminação de um craton: a Faixa Ribeira. In XXXVII Congr.Bras. Geol., São Paulo. Anais..., São Paulo, SBG, Bol. Res. Exp.: 373-374.

VERNON, R.H. - 1989 - Evidence of syndeformational contact metamorphism from porphyroblast, matrix microstructural relationships. In Tectonophysics 158(1/4):113-126.

VERNON, R.H. - 2000 - Review of microstructural evidence of magmatic and solid-state flow. In Eletronic Geosciences (2000): 5-2

VERNON, R.H.; ETHERIDGE, M.A.; WALL, V.J. -1988 - Shape and microstructure of microgranitoid enclaves: indicators of magama mingling and flow. Lithos 22: 1-12.

VERNON, R.H.; WILLIAMS, V.A. ; D'ARCY, W.F. - 1983 - Grainsize reduction and foliation development in a deformed granitoid batholith Tectonophysics 92: 123-145.

VIDAL, P. - 1994 - Géochimie. 1 ed., Paris, Dunod. 190p.

VIGNERESSE, J.L. - 1990 - Use and misuse of geophysical data to determine the shape and depth of granitic intrusions. Geol.J. 25: 249-260.

VIGNERESSE, J.L. - 1995a - Control of granite emplacement by regional deformation. Tectonophysics 249: 173-186.

VIGNERESSE, J.L. - 1995b - Crustal regime of deformation and ascent of granite magma. Tectonophysics 249: 187-202.

VIGNERESSE, J.L. - 1990 - Use and misuse of geophysical data to determine the shape at depth of granitic intrusions. Geol. J., 25: 249-260

VIGNERESSE, J.L.; BARBEY, P.; CUNEY, M. (1996) - Rheological transitions during partial melting and crystallization with applications to felsic magma segregation and transfer. Journal of Petrology 37/6:1579-1600.

VIGNERESSE, J.L.; BOUCHEZ, J.L. - 1997b - Sucessive granitic magma batches during pluton emplacement: the case of Cabeza de Araya (Spain) J.of Petrol. 38: 1767-1776.

VIGNERESSE, J.L.; BRUN, J.P. - 1983 - Les leucogranites armoricains marqueurs de la déformation régionale: apport de la gravimétrie. Bull. Soc. Géol. Fr. 25: 357-366.

VIGNERESSE, J.L. - 1999 - Should felsic magmas be considered as tectonic objects, just like faults or folds. Journal Structural Geology 21(1999):1125-1130.

VIGNERESSE, J.L. - 1988 - Formes et volumes des plutons granitiques.Bull. Soc. géol. France, (8), t. IV, nº6: 897-906.

VIGNERESSE, J.L.1988b Heat flow, heat production and crustal structure in peri-atlantic regions. Earth Planet. Sci.Lett. 87: 303-312.

.VLACH, S.R.F. JANASI, V.A.; VASCONCELLOS, A.C.B.O. - 1990 - The itu belt: associated calc-alcaline and alumineous A-type late brasiliano granitoids in the states of 
São Paulo and Paraná. southern Brazil. In XXXVI Congresso Brasileiro de Geologia, Natal. 1990. Boletim de Resumos Expandidos.Natal-RN, SBG 4: 1700-1711.

WERNICK, E. - 1979 - O magmatismo granitóide das regiões de Dobramento Nordeste e Sudeste do Brasil. Rev. Bras. Geoc. 9: 122-139.

WERNICK, E. - 1984 - Caracterização genética de algunos granitóides brasilianos dos estados de São Paulo e Minas Garais e implicacões geotectônicas preliminares. Rev. Bras. Geoc. 14: 22-39.

WERNICK, E. - 1990 - Zoneamento magmático regional de granitóides brasiliano no sudeste/sul do Brasil: implicações geotectônicas. In XXXVI Congresso Brasileiro de Geologia, Natal, 1990. Anais... Natal, SBG, 4: 1668-1683.

WERNICK, E. - 2000 - Arc-related rapakivi granites from the Ribeira Fold Belt. In: Revista Brasileira de Geologia, SBG (30)1: 20-24.

WERNICK, E; ARTUR, A.C.; FERREIRA, C.J. - 1995 - Evolução magmática em complexos granitóide associados à zonas de cisalhamento no Estado de São Paulo, Brasil. Revista Brasileira de Geociências, São Paulo, 14 (1): 199-216.

WERNICK, E.; GALENBECK, T.M.B. - 1985 - Contribução à caracterização de granitóides do Estado de São Paulo através do mineral acessório zirconita. V Simpósio Regional de Geologia, São Paulo, 1985. Atas... São Paulo,1 :19-132.

WERNICK, E.; HÖRMANN, P.K.; ARTUR, A.C.; FERREIRA, C.J.; GALLENBECK, T.M.B.; GODOY, A.M.; ANDRADE, F.R.D. - 1993 - Fases, impulsos magmáticos em complexos granitóides associados com falhas transcorrentes, SP. Rev. Bras. Geoc. 23 (3): 248-259.

WHITE, A.J.R.; CHAPPELL, .W. - 1976 - Ultrametamorphism and Granitoide genesis. Tectonophysics 43: 7-22

WIBBERLEY, C. - 1999 - Are feldspar-to-mica reactions necessarily reaction-softening processes in fault zones. Journal Structural Geology 21: 1219-1227.

WICKHAN, S.M. - 1987 - The segregation and emplacement of granitic magmas. Journ. Geol. Soc. London 144: 281-297.

WIEDEMANN, C.M. - 1993 - The evolution of the Paleozzoic, late- to post-collisional magmatic arc of the coastal mobile belt, in the state of Espirito Santo, eastern Brazil. An. Acad. Bras. Ciênc. 65 (Supl. 1): 163-181

WIEDEMANN, C.M.; BAYER, P.; HORN, H.; LAMMERER, B.; LUDKA, I.P.; SCMIDT. THOME,R.; WEBER-DIEFENBACH, K.-1986- Maciços intrusivos do sul do Espírito Santo e seu contexto regional. Rev. Bras. Geoc. 16 (1): 24-37.

WIEDEMANN, C.M.; PENHA, H.M.; SCMIDT-THOME, R. - 1987 - Granitóides do Espírito Santo and Rio de Janeiro States. Rev. Bras. Geoc. 17 (4): 674-689.

WIEDEMANN, C.M.; WEBER-DIEFENBACH, K.; LUDKA, I.P. -1986a- Introdução a geoquímica de elementos maiores, menores e traços do Complexo Jacutinga - Torre, Mimoso do Sul, Espírito Santo. In Congresso Brasileiro de Geologia, Goiânia, SBG, 1996, v.6: $2877-28907$.

WILLIAMSON, H.D.; THIRLWALL, M.F. - 1992 - The relationship between crustal magmatic underplateing and granite genesis: an example from the Velay granite complex, Massif Central, France. Trans. Royal Soc. Ed.: Earth Sci. 83: 235-245.

WINKLER, 1967-Petrogênese das rochas metamórficas. Tradução da 4 a edição. Porto Alegre, Edgard Blucher / UFRGS. 254p.

WOODCOCK, N.H.- 1986 - The role of strike-slip fault at plate boundaries. Phil. Trans. Royal Soc. London, A317: 13-29. 
YENES, M; ÁLVAREZ, F.; GUTIÉRREZ-ALONSO, G. - 1999 - Granite emplacement in orogenic compressional conditions: the La Alberca-Béjar granitic area (Spanish Central System, Variscan Iberian Belt). Journal Structural Geology 21(1999):1419-1440.

.ZIMBRES, E.; KAWASHITA, K.; VAN SCHMUS, W.R. - 1990 - Evidências de um núcleo transamazônico na região de Cabo Frio, RJ e correlação com o Cráton da Angola. In XXXVI Congresso Brasileiro de Geologia, Natal, 1990. Anais... Natal, SBG, 6: 2723-2743.

ZORITA, M.E.; PENHA, H.M. - 1980 - Geoquímica das rochas graniticas da região de Surui, Magé, RJ. In XXXI Congresso Brasileiro de Geologia, Camboriú, 1980. Anais...Camboriú, SBG, 4, 2391-2399. 


\section{APÊNDICE 1}

7.1. Trabalho de Campo

7.1.1. Análise Geométrica

7.1.2. Análise Cinemática

7.1.3. Gravimetria

7.2 Fase de Laboratório

7.2.1. Análises Petrográficas e microestruturais

7.2.2. Análises Litogeoquímicas

7.2.3. Análises da Quimica Minera!

7.3. Fase de Gabinete

7.3.1. Sensoriamento remoto

\subsection{Trabalho de Campo}

Os métodos utilizados ao longo dos trabalhos de campo consistiram em:

Realização de perfis transversais e longitudinais ao Dominio Arrozal (Geologia Regional). Cada perfil teve como procedimento a observação e anotação sistemática das estruturas primárias e tectônicas $e$ coletas de amostras orientadas (quando possivel) para análise de orientação dos tensores.

Na região de Arrozal foram executados mapeamentos sistemáticos nas escalas 1:50.000 (folhas Volta Redonda, Pirai, Itaguai, ao longo dos últimos 10 anos); 1:30.000 nas folhas Volta Redonda e 1:10.000 no Maciço Granítico Arrozal.

Procurou-se também descrever estruturas meso e macroscópicas posicionando-as em perfis de análise geométrica de estruturas com suas respectivas relações quanto à cronologia seqüencial das estruturas primárias e tectônicas; descrições dos elementos estruturais controladores do produto final (granito X macroestrutura); descrição e caracterização dos padrões de superposição de estruturas tectônicas onde o resultado final foi demonstrado através do ordenamento cinemático e distribuição das estruturas em cartograma digitalizado através da compilação dos dados litológicos e estruturais.

Integração de algumas informações baseadas na análise e interpretação de imagens de satélite LANDSAT - TM 5 (Banda 3).

\subsubsection{Análise Geométrica}

A análise geométrica compreendeu na elaboração de estereogramas com a utilização do software Stereonet 2, para os diferentes Dominios Estruturais Homogêneos NW, Central e SE (APENDDICE 2).

A nomenclatura utilizada seguiu convenções para trabalhos realizados em mapeamentos geológicos regionais (Tumer Weiss 1976).

Para os dados estruturais foram utilizados os seguintes simbolos:

$\mathrm{C}$ - foliação milonitica

$S n+1$ - foliação tectônica regional principal (S3 regional)

$S n$ - foliação anterior a foliação principal regional (S1 e S2 não diferenciadas)

Sf - foliação de fluxo ígneo preservada

SC - planos SC miloníticos)

Lm - lineação mineral

Lx - lineação de estiramento mineral

$\mathrm{Li}$ - lineação de interseção 
E - eixo de dobra

$\mathrm{Fr}$ - fraturas em conjugados de Riedel

$F$ - falhas

e-estria de falha e $P$ - planos de falha.

Estereogramas - são anexados aos diferentes tipos litológicos, utilizando-se os diagramas de Schimidt (hemisfério inferior), com uso do programa para microcomputadores Stereonet 2 e Ester (UNICAMP-CPRM).

\subsubsection{Análise Cinemática}

A análise cinemática teve início nos trabalhos de campo, com a anotação e respectiva interpretação dos marcadores cinemáticos, que registram os diferentes elementos rotacionais no desenvolvimento de foliações e lineações em zonas de cisalhamento dúcteis. Posteriormente, com o mapa estrutural, estereogramas e caderneta de campo, realizou-se uma campanha visando especificamente estudar os marcadores cinemáticos para interpretar a evolução dos tensores de deformação na região de Arrozal.

\subsubsection{Gravimetria}

Consistiu em realizar deslocamentos nas estradas e rodovias existentes na região de Arrozal, fazendo leituras gravimétricas e altimétricas (dois altimetros) a cada quilômetro na região interna da Suite Intrusiva Arrozal, e a cada três quilômetros próximos ao corpo (nas rochas hospedeiras).

Para este trabalho utilizou-se os seguintes materiais e equipamentos:

1. GRAVIMETRO La Coste - Romberg, número 987, cedido pela UNESP - Rio Claro - Depto. de Geofísica; cinco altímetros - barométricos da marca Paulling, cinco termômetros com escala em graus Farenhait (absolutos).

2. Folhas topográficas VR(SH 23-) PI (SH-23) para plotagem de pontos georreferenciados (UTM).

\section{Trabalho de campo}

Os trabalhos de campo de gravimetria foram dividido em duas atividades: serviço de apoio na base fixa de Arrozal (uma pessoa) que posicionou o altímetro barométrico no centro da soleira da porta principal da Igreja Matriz (VR), sobre o furo de cimento que trava o trinco da porta, localizada na Praça Ponce de Leon, de RN - Igreja do IBGE (VR), e trabalhos de campo com as respectivas medições (duas pessoas).

O serviço de apoio das anotações altimétricas, na base deslocada para Arrozal (instalada na soleira da porta principal da Igreja de Arrozal) teve a colaboração do técnico Robson de Souza Vicente. Consistia em anotar a cada 10 minutos os valores obtidos pelos três altimetros da base, e as variações de temperaturas dos termômetros.

A localização precisa de todos os pontos gravimétricos foram determinados por GPS - Maggelan, e plotados posteriormente nas folhas 1:50.000, Volta Redonda e Pirai , enumerados com os códigos BG-VR + número da base gravimétrica. Apenas algumas estações dentro da folha Vassouras não foram plotadas.

Algumas áreas que não foram ainda contempladas por mapeamentos de detalhe (Barra do Pirai, Santanésia, Vargem Alegre, Sanatório da Serra e Eng. Morsing, ao norte da área e, Rio Claro, Faz. Santa Helena, Passa Três, ao sul) obtiveram resultados parciais que foram relacionados a áreas interpretadas como rochas hospedeiras (Dominios Quirino e Serra das Araras).

O trabaho de campo de gravimetria foi realizado em aproximadamente 78 horas (sete dias consecutivos entre 7:10 e 18:40h). As temperaturas foram moderadas (picos máximos as 12:00 ou 13:00h) caindo ao entardecer, sem haver nenhuma precipitação pluviométrica ao longo dos trabalhos. A periodo do ano mais apropriado para realização dos trabalhos de campo na região de Arrozal é abril, maio e junho (época de estiagem). 
As correções de altimetria envolveram os parâmetros de temperatura, barometria e altitudes (estas mais importantes), onde foram utilizados os programas ALTGRAV.

As reduções gravimétricas levaram em consideração principalmente os parâmetros de densidade das rochas, correções altimétricas e deriva do aparelho, onde utilizou-se o programa GRAVISYS.

\section{Descrição detalhada do levantamento (gravimetria, planimetria (GPS) e altimetria}

Foram realizados aproximadamente 20 perfis em malha lateral de $3 \mathrm{~km}$. inicial para calibragem e dimensionamento das anomalias. Cada perfil teve como procedimento, a observação e anotação sistemática dos dados gravimétricos, acompanhado de planimetria (GPS) e altimetria, e demarcação em mapas ou nas cartas topográficas de pontos de controle para cada perfil.

\section{Localização da área e espaçamento da observações}

Numa segunda etapa de campo foi adensada a malha parcialmente regular, com espaçamentos entre estações de aproximadamente $1 \mathrm{~km}$.

Relevo: diferenças de cotas altimétricas máximas e mínimas na região de Arrozal

Cota mais elevada: $697 \mathrm{~m}$ - Cota mais baixa: $400 \mathrm{~m}$

Relevo moderado com altitude média em torno de $550 \mathrm{~m}$

Vias de Acesso: A região estudada é permeada por estradas não asfaltadas, praticamente planas e de fácil acesso e situa-se próximo ao município de Arrozal (15 Km a sudeste de Volta Redonda) cortada pela Via Presidente Dutra. O deslocamento no interior da área foi efetuado por veículo tracionado.

Redes básicas - RN próximas

RN 17K, RN1000J, RN 100N, RN 1001A, RN 11D, RN 1001E, RN 11E.

Estação da Rede Gravimétrica Fundamental Brasileira (RGFB)

Número da estação 010376 - Nome da Estação: Barra Mansa "B"

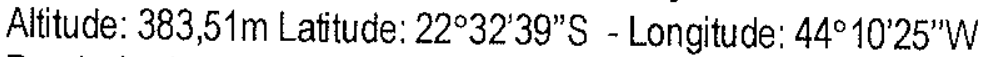

Provincia do estado do Rio de Janeiro (Estabelecido pelo Observatório Nacional em abril de 1976)

Dimensões do corpo granítico

Comprimento maior: $36 \mathrm{~km}$, Largura: $8 \mathrm{~km}$, Area total: $101,3 \mathrm{~km} 2$

Etapas de trabalho:

1.Correções e cálculos dos valores das anomalias gravimétricas

Erro aceitável na barometria $=2 \cdot 3 \mathrm{~m}$

Erro de dado gravimétrico aceitável $=1,5 \mathrm{mgal}$

2. Cálculo das densidades - Método utilizado: Deslocamento de líquidos - fórmula de densidade para sólidos, neste caso cilindrica. Os valores de densidades foram obtidos na Departamento de Fisica Experimental da UFRRJ.

3.Confecção de mapas de isogálicas :Mapa Bouguer 2D elaborado no programa SURFER for Windows e posteriormente DATAMINE (INCO, Sudbury, CA).

\subsection{Fase de Laboratório}

\subsubsection{Análises Petrográficas e microestruturais}

Foram confeccionadas 89 laminas delgadas de amostras dos diferentes Dominios, a nivel regional, e apenas na Suite Intrusiva Arrozal, confeccionou-se 255 lâminas delgadas, muitas destas orientadas. As amostras foram marcadas com a sigla VR@ ou MAVR, seguidos do número da amostra. A metodologia desta fase consistiu nos seguintes procedimentos:

a) Confecção de lâminas delgadas normais e orientadas (2 ou 3 seções por amostra);

b) Descrição de lâminas delgadas para fins de identificação de estruturas e minerais primários (em granitos) e suas relações com a fábrica tectônica das encaixantes; 
c) Informatização dos dados estruturais para entendimento da trajetória das microestruturas de fluxo magmático planares e lineares, dados gerais de campo e padrões de fraturas em granitos, e subsequente tratamento estatistico dos objetos deformados das encaixantes

d) coleta sistemática de amostras para estudos de laboratório (petrografia, geoquímica e microssonda eletrônica);

\section{Dados petrográficos}

Valores dos tamanhos de grãos minerais das litologias empregadas neste trabalho:

$5-7 \mathrm{~mm}$-muito grossa

$3-5 \mathrm{~mm}$ - grossa

$1.3 \mathrm{~mm}$ - média

$0,1-3 \mathrm{~mm}-$ fina

$<0,1 \mathrm{~mm}$-muito fina

\subsubsection{Análises Litogeoquímicas}

A fase de laboratório, consistiu das seguintes atividades:

1. Preparação e moagem das amostras de rocha da SIA e suas encaixantes (Dominio Quirino),

2. Geoquímica isotópica realizada no Laboratório de Geoquimica Isotópica da USP (dados não utilizados nesta tese).

3. Análises quimicas de rochas para elementos maiores (LIL): $\mathrm{Si}, \mathrm{Al}, \mathrm{Fe}, \mathrm{Mg}, \mathrm{Ca}, \mathrm{Na}, \mathrm{K}$; menores: Ti, P, Mn; Perda ao Fogo: $\mathrm{H} 2 \mathrm{O}+, \mathrm{H} 2 \mathrm{O}-, \mathrm{O} 2$ e traços; $\mathrm{Zr}, \mathrm{Y}, \mathrm{Sr}, \mathrm{Rb}, \mathrm{Ba}, \mathrm{Sc}, \mathrm{Nb}$; elementos terras raras (REE) foram analisadas no Laboratório ACTLABS, Canadá.

\section{Consulta bibliográfica temática (GEOREF);}

5. Montagem da litoteca do projeto; 2.02).

6. Informatização e análise dos dados nos programas (EXCELL 97, POWER POINT e MINPET

Dados anailiticos:

As análises litogeoquimicas foram efetuadas nos laboratórios: Activation Laboratories, Ontário, Canadá e Laboratório de Geologia da École de Mines de Saint-Etienne, França.

Os dados foram obtidos por Espectometria de Fluorescência de Raio - $X$, em espectrômetro Philips, modelo PW 1404, e Espectometria de Emissão Atômica com plasma de Argônio induzido (ICP-AES) (Induced Coupled Plasma), empregando-se espectrômetro modelo JY38PI e JY32P. A precisão dos resultados foi obtida pela comparação e aferição com os padrões internacionais certificados, utilizados simultaneamente nas determinações de cada conjunto de amostras.

Os limites de deteç̧ão dos diferentes elementos traços determinados por fluorescência de Raio- $X$, foram: 1,5 ppm para Sr, Y, Zr e Nb; 2 ppm para Ni, Cu, Zn, Ga, e Rb; 3 ppm para Hf, W, Pb, Sn, Th, e U; 3,5 ppm para Ba; 5 ppm para Cs; 7,5 ppm para La e 8 ppm para o elemento $\mathrm{Ce}$. Os elementos maiores, expressos sob a forma de óxidos, os limites de detecção são: $2 \%$ para $\mathrm{SiO} 2$ e 5\% para $\mathrm{Al} 2 \mathrm{O} 3$, $\mathrm{Fe} 2 \mathrm{O} 3$, $\mathrm{CaO}$, $\mathrm{Na} 2 \mathrm{O}, \mathrm{K} 2 \mathrm{O}, \mathrm{MgO}, \mathrm{TiO} 2, \mathrm{MnO}$ e $\mathrm{H} 2 \mathrm{O}$. A determinação de elementos maiores foi executada pelas duas técnicas espectométricas, Raio X e ICP, permitindo a comparação entre os resultados e/ou sua utilização pelos métodos complementares de análise. $O$ método por ICP é mais sensivel e indicado para as determinações de $\mathrm{MgO}, \mathrm{MnO}, \mathrm{CaO}$ e $\mathrm{TiO} 2$, pois suas concentrações são muito pequenas em granitos mais evoluidos, como é o caso do MGG e MGF da Suite Intrusiva Arrozal.

\subsection{Fase de Gabinete}


A Fase de Gabinete compreendeu a produção gráfica dos trabalhos realizados em sua forma final (cartogramas, tabelas, gráficos, figuras, fotografias, etc.) e a redação da presente tese. As figuras, diagramas e mapas foram todas confeccionadas pelo autor.

Foram consultados e pesquisados, uma grande gama de artigos, cujas referências via GEOREF Internet, através das key words: granitos em zonas de cisalhamento, transpressão e transtração, zonas de cisalhamento, fluxo magmático e deformacional, compreendidos no periodo de 1989 a 1999.

\subsubsection{Sensoriamento Remoto}

Os estudos de análise e interpretação das imagens LANDSAT- TM5 compreenderam os seguintes passos:

1. Correção geométrica da imagem datada de 23 de junho de 1993;

2. Aplicação de filtros na banda 3 para realçar as estruturas da imagem;

3. Digitalização em tela de estruturas lineares:

4. Sobreposição dos temas sobre a imagem e posterior impressão.

Os programas ENVI e $\mathrm{PCl}$ foram utilizados para análise da imagem de satélite e georreferenciamento da região estudada. O MaxCad para a confeç̧ão dos mapas geológico e estruturais. A base plano altimetrica digitalizada foi cedida pela equipe do Laboratório de Geoprocessamento da UERJ. 


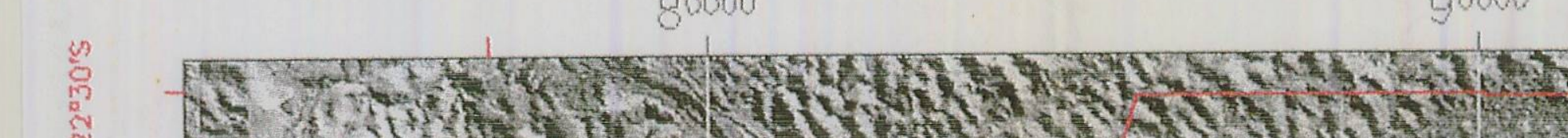

1)

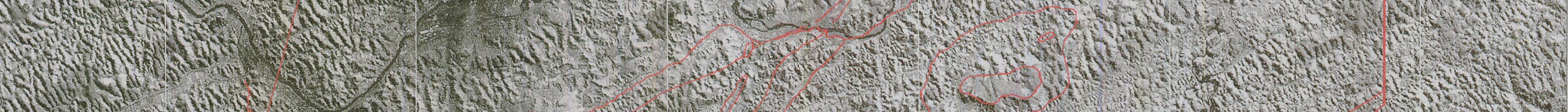

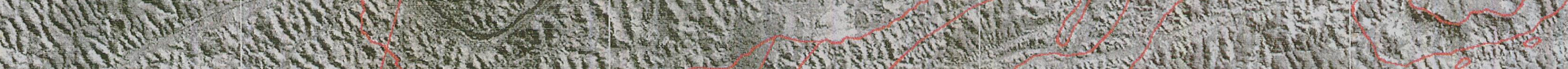

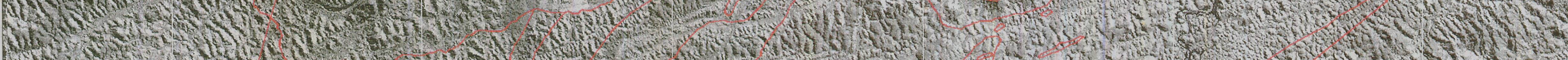

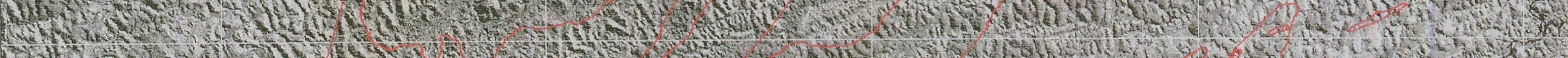

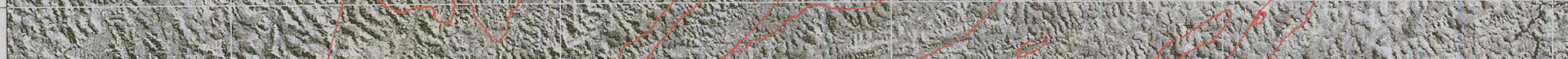

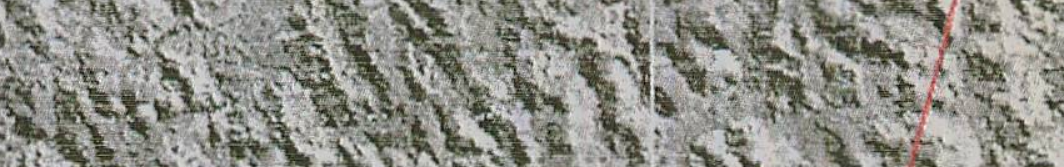

W.

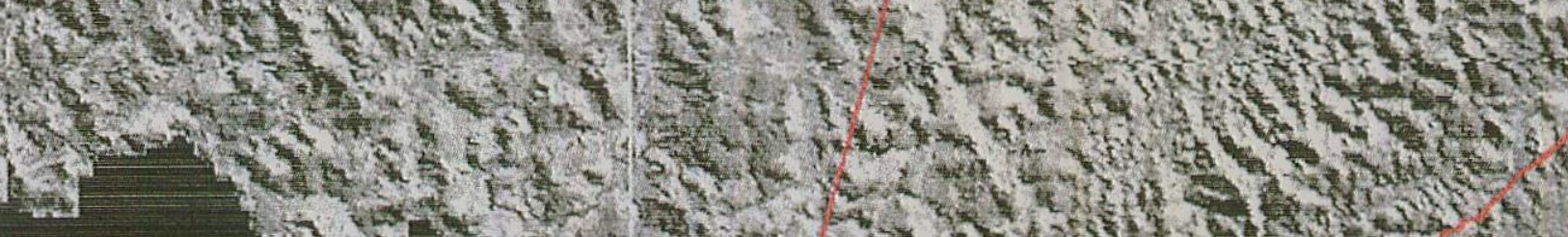

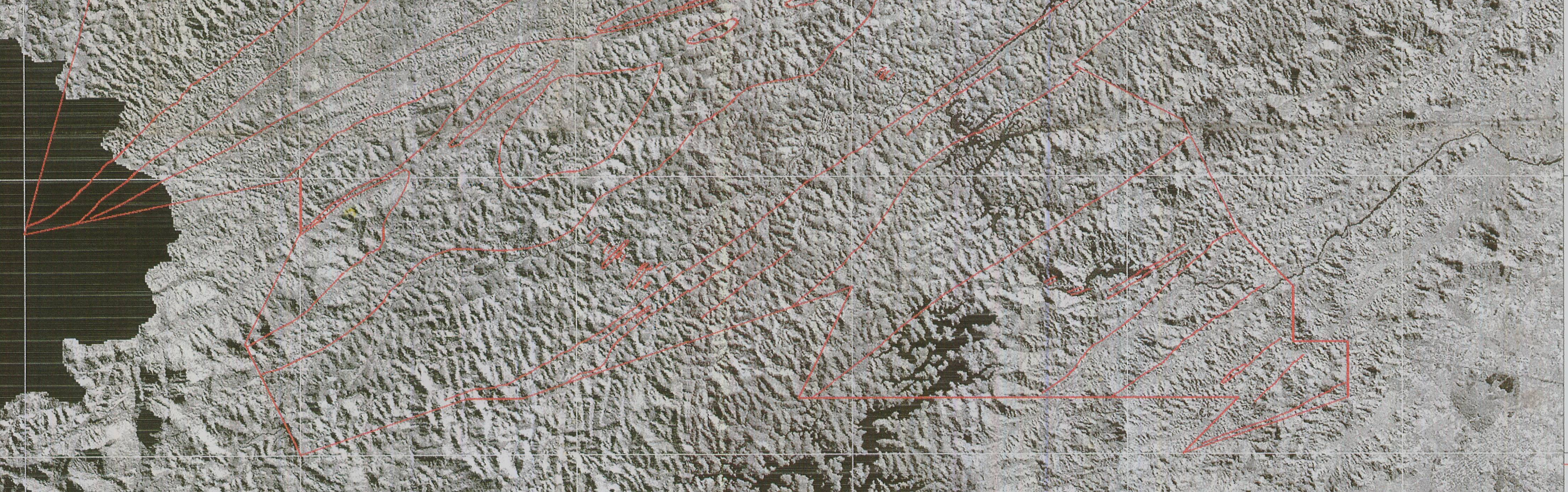

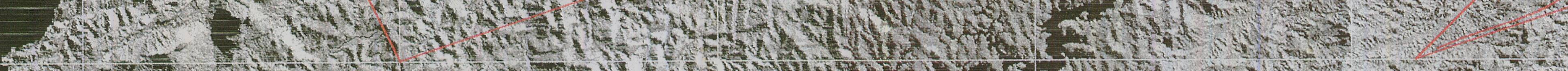

ar. 


\section{Apêndice 2}

N

Domínio Estrutural Homogêeneo Noroeste

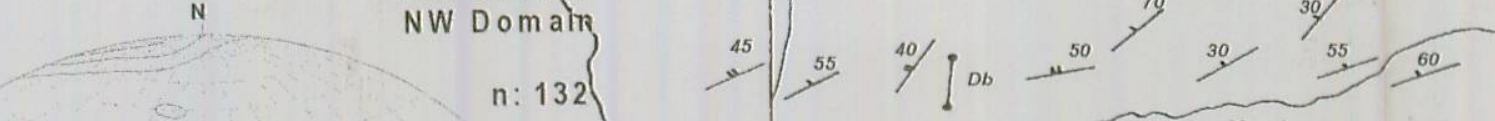

0

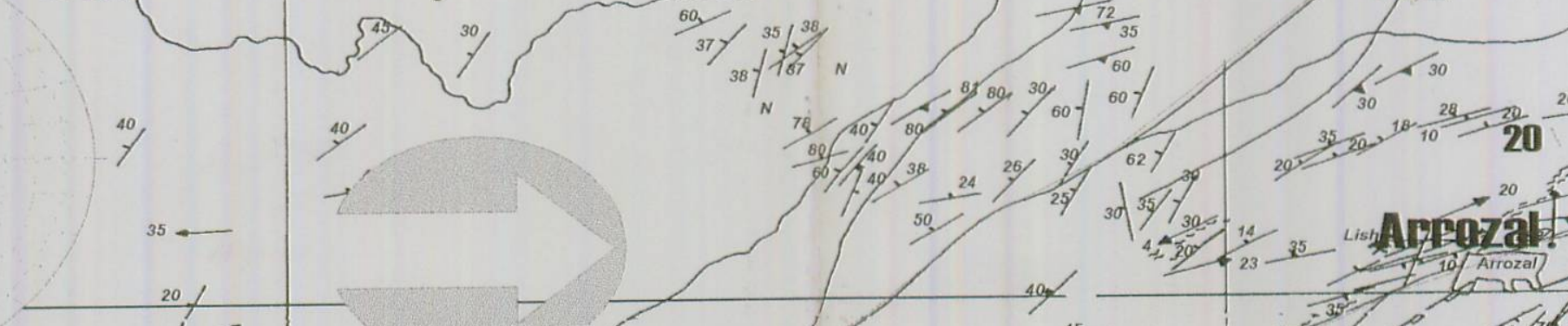

\section{Domínio Cèntral}

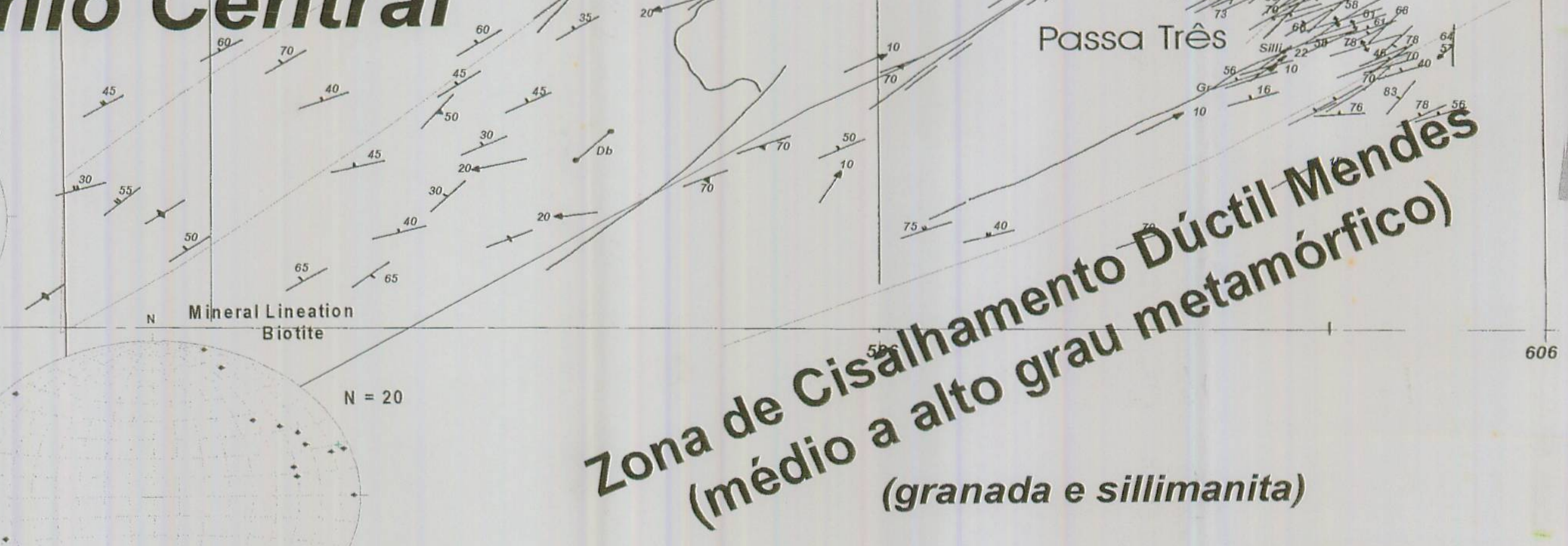

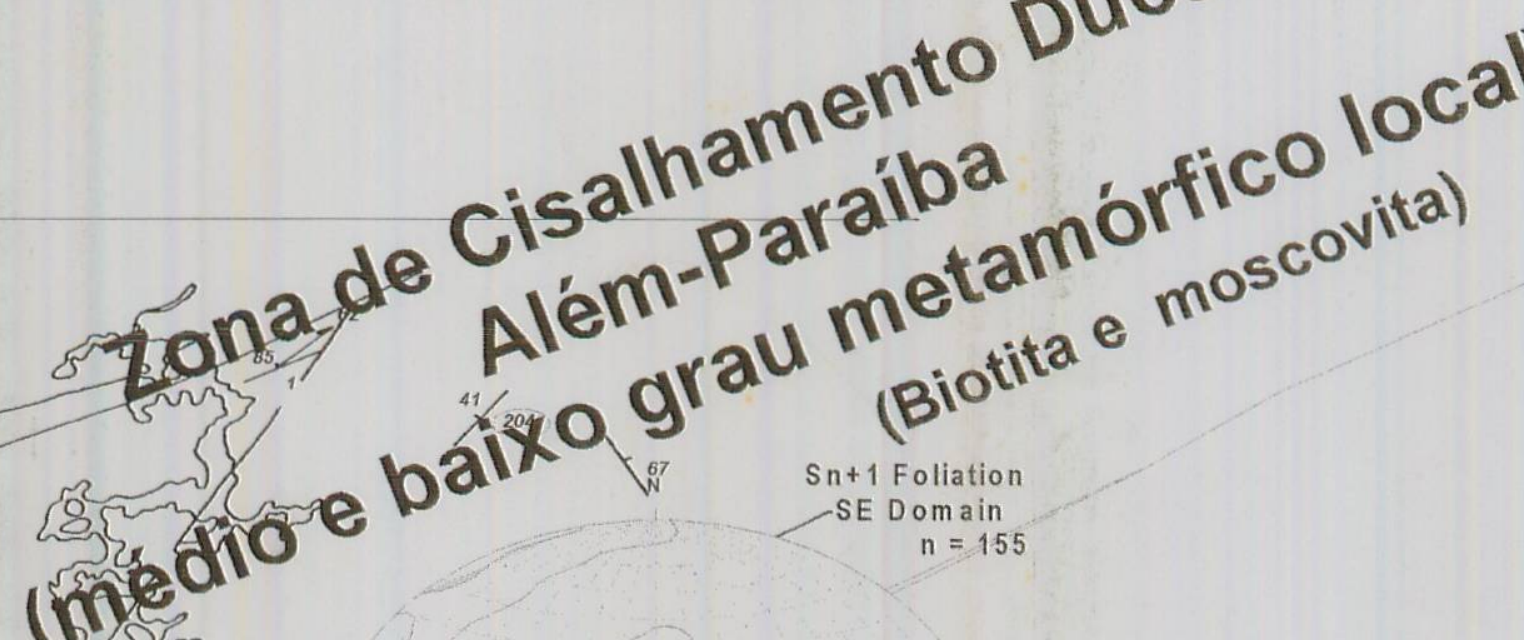

im

Mapa ESTRUTURAL da Suíte Intrusiva Arrozal, 